\title{
Our climate, our underground
}

\author{
Citation for published version (APA):
}

van Oost, B. (2016). Our climate, our underground: understanding the slow implementation of carbon capture and storage. [Doctoral Thesis, Maastricht University]. Maastricht University. https://doi.org/10.26481/dis.20161220bo

Document status and date:

Published: 01/01/2016

DOI:

10.26481/dis.20161220bo

Document Version:

Publisher's PDF, also known as Version of record

\section{Please check the document version of this publication:}

- A submitted manuscript is the version of the article upon submission and before peer-review. There can be important differences between the submitted version and the official published version of record.

People interested in the research are advised to contact the author for the final version of the publication, or visit the DOI to the publisher's website.

- The final author version and the galley proof are versions of the publication after peer review.

- The final published version features the final layout of the paper including the volume, issue and page numbers.

Link to publication

\footnotetext{
General rights rights.

- You may freely distribute the URL identifying the publication in the public portal. please follow below link for the End User Agreement:

www.umlib.nl/taverne-license

Take down policy

If you believe that this document breaches copyright please contact us at:

repository@maastrichtuniversity.nl

providing details and we will investigate your claim.
}

Copyright and moral rights for the publications made accessible in the public portal are retained by the authors and/or other copyright owners and it is a condition of accessing publications that users recognise and abide by the legal requirements associated with these

- Users may download and print one copy of any publication from the public portal for the purpose of private study or research.

- You may not further distribute the material or use it for any profit-making activity or commercial gain

If the publication is distributed under the terms of Article $25 \mathrm{fa}$ of the Dutch Copyright Act, indicated by the "Taverne" license above, 


\section{Our climate, our underground}

\section{Understanding the slow implementation of carbon capture and storage}


Copyright (c) 2016, Bart van Oost

Cover design door Jesse Schaap ('Nee heb je, Jesse kan je krijgen’).

The printing of this dissertation has been financially supported by the Netherlands Graduate Research School for Science, Technology and Modern Culture (WTMC). 


\title{
Our climate, our underground
}

\section{Understanding the slow implementation of carbon capture and storage}

\author{
PROEFSCHRIFT \\ ter verkrijging van de graad van doctor aan de Universiteit Maastricht, \\ op gezag van de Rector Magnificus, Prof. dr. R.M. Letschert, \\ volgens het besluit van het College van Decanen, \\ in het openbaar te verdedigen op dinsdag 20 december 2016 om 16:00 uur
}

door

BART VAN OOST 


\section{Promotor:}

Prof. dr. ir. Wiebe Bijker

\section{Copromotor:}

Dr. Anique Hommels

Beoordelingscommissie:

Prof. dr. ir H. van Lente (voorzitter)

Prof. dr. T. Swierstra

Prof. dr. S. Wyatt

Prof. dr. ir. R.P.J.M. Raven (Universiteit Utrecht) 


\section{Table of Contents}

Table of Contents $\quad 5$

$\begin{array}{ll}\text { List of acronyms and abbreviations } & 8\end{array}$

Acknowledgments 9

1 Introduction 11

$\begin{array}{lll}1.1 & \mathrm{CO}_{2} \text { capture and storage } & 15\end{array}$

1.2 CCS as an emerging socio-technical system 22

1.3 Research design and methodology 23

$2 \quad$ Imagining a collective energy future, constructing necessity 27

2.1 Studying socio-technical imaginaries 29

2.2 Research design 31

2.3 The Netherlands - a transit place for fossil flows 33

2.4 Risks and benefits as incentives for change $\quad 35$

2.4.1 Global warming and national targets 35

2.4.2 Vulnerability of the Dutch energy economy 38

2.5 Knowledge on the Dutch energy future $\quad 41$

2.5.1 Looking ahead, ranking pathways 41

2.5.2 Reasoning backwards to identify future barriers 45

2.6 Changing responsibilities for energy reform 46

2.6.1 Transitions as collective journeys 47

2.6.2 From wait-and-see to a CCS Task Force 50

2.7 Realizing closure in an open economy $\quad 52$

2.7.1 A bridge or a dead end? 54

2.7.2 Visions of hubs and roundabouts 57

2.7.3 The performativity of expectations 62

2.8 Conclusion 66

3 Framing safety and the politics of expertise 69

3.1 Frames, overflows and hybrid forums $\quad 71$

$\begin{array}{lll}3.2 & \text { Research design } & 75\end{array}$

$\begin{array}{lll}3.3 & \text { Setting the stage } & 77\end{array}$

3.4 The Environmental Impact Assessment procedure 79 
3.4.1 Criticizing the MER, constructing overflows 82

3.5 The local Toetskader $\quad 84$

3.5.1 Enrolling 'critical' experts 85

3.5.2 The Knowledge Table as a hybrid forum 87

3.5.3 Containing overflows through focused inquiry and peer review 88

3.5.4 Ignorance and the 'paper reality' of safety studies 90

3.6 Shifting to the national level 93

3.6.1 Uncertainty claims and the mobilization of a concerned public 95

3.6.2 The CATO research consortium and scientific authority 98

3.6.3 The Fact Finding Workshop as a hybrid forum 105

3.6.4 Problem structuration and multi-level tensions 107

$\begin{array}{lll}3.7 \text { Conclusion } & 110\end{array}$

4 A promising or proven technology? Boundary work in the regulation of commercial-scale CCS

4.1 Standards, evidence and boundary work 117

4.2 Research design $\quad 120$

$\begin{array}{ll}4.3 & \text { Regulating the American air } \\ & 122\end{array}$

4.3.1 Climate politics and the promise of CCS 123

4.4 Determining a 'normal' emission profile $\quad 127$

4.4.1 Turning expectations into evidence 131

4.4.2 Governing future CCS development 133

4.5 Permitting a clean coal plant in Illinois $\quad 134$

4.5.1 The Taylorville Energy Center 135

4.5.2 Illinois-EPA and the permitting process 138

4.5.3 Different standards of evidence 140

4.5.4 Demonstrator's regress and EPA's intervention 142

4.6 Scientific scrutiny, political opposition and legal challenges $\quad 145$

4.6.1 Repositioning at the Science Advisory Board 146

4.6.2 Political attempts to curtail EPA's room for action 149

4.6.3 Legal challenges and EPA's final rule 150

4.7 Conclusion 153

$\begin{array}{lll}5 & \text { Conclusions and reflection } & 157\end{array}$

$\begin{array}{ll}\text { Appendices } & 163\end{array}$

Appendix A - List of interviewees $\quad 164$

Appendix B - Chronology of the Barendrecht controversy 166

Appendix C - Chronology of EPA's standard-setting process 169 
Appendix D - Selection of US Committee meetings on CCS

References

Nederlandse samenvatting

Valorisation addendum

Curriculum Vitae

203 


\section{List of acronyms and abbreviations}

\begin{tabular}{|c|c|}
\hline BACT & Best Available Control Technology \\
\hline BSER & Best System of Emissions Reduction \\
\hline CATO & Dutch Research Consortium for $\mathrm{CO}_{2}$ Afvang-, Transport en Opslag \\
\hline CCS & Carbon Capture and Storage \\
\hline CDA & Christian Democratic Party Netherlands \\
\hline DCMR & Environmental Protection Agency of region Rotterdam-Rijnmond \\
\hline DOE & US Department of Energy \\
\hline EDN & Energy Dialogue Netherlands \\
\hline EOR & Enhanced Oil Recovery \\
\hline EPA & US Environmental Protection Agency \\
\hline EU-ETS & European Union's Emission Trading Scheme \\
\hline EZ & Dutch Ministry of Economic affairs \\
\hline IBDP & Illinois Basin Decatur Project \\
\hline IEA & International Energy Agency \\
\hline IEA-GHG & International Energy Agency’s Greenhouse Gas Research \& Development Programme \\
\hline GHG & Greenhouse Gas \\
\hline IGCC & Integrated Gasification Combined Cycle power plant \\
\hline MER & Environmental Impact Assessment \\
\hline NAAQS & National Ambient Air Quality Standard \\
\hline NETL & US National Energy Technology Laboratory \\
\hline NMP & Dutch National Environmental Policy Plan \\
\hline NRDC & US National Resources Defense Council \\
\hline NSPS & New Source Performance Standard \\
\hline $\mathrm{OMB}$ & US Office of Management and Budget \\
\hline PvdA & Dutch Labour Party \\
\hline QRA & Quantitative Risk Assessment \\
\hline RIVM & Dutch National Institute for Public Health and the Environment \\
\hline $\mathrm{SAB}$ & EPA's Science Advisory Board \\
\hline SNM & Dutch Organisation for Nature and Environment \\
\hline TEC & Taylorville Energy Center Illinois \\
\hline TNO & Netherlands Organisation for Applied Scientific Research \\
\hline VROM & Dutch Ministry of Public Health, Spatial Planning and Environmental Affairs \\
\hline VRR & Safety Region Rotterdam \\
\hline VVD & Dutch Liberal Party \\
\hline
\end{tabular}




\section{Acknowledgments}

There are many people who have supported me on my academic journey. First of all, I want to thank Wiebe Bijker and Anique Hommels. They were the most generous supervisors, allowing me to develop my own research and providing intellectual guidance, inspiration and constructive feedback along the way. I am very grateful for their encouragement, trust and patience. I also want to thank the interviewees who participated in this study. They took time out of their busy schedules to introduce me to things that I knew little about: the deep underground, aquifers, pancake plugs, bowties and FEPs, lobbying strategies, the business case for coal. It was inspiring to see that almost all respondents, although diverse in backgrounds and opinions, were serious about climate change and tried to realize energy reform in the best way possible.

I want to thank Jessica Mesman for her kindness and encouragement in the early stage of my career. Thanks to Jens Lachmund, who gave me the opportunity to gain valuable teaching experience. Thanks to Teun Zuiderent-Jerak and Willem Halffman for organizing the WTMC workshops and Summer Schools which provided an excellent introduction to the curious field of STS. Thanks to the committee members for their thoughtful comments, allowing me to improve my work. Thanks to Marjolein van Asselt for helping me with the valorisation of my research. Thanks to Koen Beumer, Aant Elzinga, Marijke Hermans, Aalok Khandekar, Harro van Lente, Andreas Mitzschke, Cyrus Mody and Govert Valkenburg for giving valuable feedback on earlier versions of my chapters. Thanks also to Joeri Bruyninckx, Kim Caarls, Eefje Cleophas, Tessa Fox, Nataliia Gladkova, Dirk Haen, Tim van der Heijden, Maria Herkelrath, Tjörven Rasera, Alexander Strelkov, Deborah Werner and all the other colleagues who made my time in Maastricht such a joy. Thanks to my philosopher friends Tom Maassen and Arthur Willemse for reminding me to wonder. Ik wil mijn ouders bedanken, omdat ze mij de middelen én de vrijheid gaven om mijzelf te ontwikkelen. Ik wil ook mijn schoonouders bedanken: hun interesse voor mijn werk en schrijfproces heb ik zeer gewaardeerd. En het allerbelangrijkste, dat ben jij Marleen. De afgelopen vijf jaar zijn we tien jaar ouder geworden. En wijzer. Zonder jou had ik dit onderzoek nooit kunnen doen. 



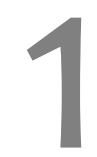

\section{Introduction}


Since roughly the 1980 s, global warming has turned into an object of major political concern. Scientific studies suggest that increased concentrations of $\mathrm{CO}_{2}$ and other greenhouse gases cause climate change by trapping heat in the Earth's atmosphere. This insight has given rise to numerous international agreements, like the emblematic Kyoto Protocol and its proposed successors. At the heart of such agreements is the conviction that a stark reduction of global $\mathrm{CO}_{2}$ emissions is needed in order to keep global warming within limits (given the associated adverse effects like sea level rise, more extreme weather conditions or biodiversity loss). Anthropogenic climate change is routinely linked to the burning of fossil fuels. Since the industrial era, coal, oil and natural gas are used to power modern life. Most climate policies focus therefore on reducing the share of fossil fuels in the global energy mix, either by (i) saving energy or (ii) switching to alternative energy sources like wind, solar, nuclear or hydropower. It is unclear though whether these strategies will suffice. As new techniques are being developed to extract fossil fuels from the underground and new coal-fired power plants continue to be built around the globe, it is generally expected that fossil fuels will remain the world's primary energy source for decades to come. In turn, a third climate strategy has gained prominence: Carbon Capture and Storage (CCS). This entails the capture of $\mathrm{CO}_{2}$ at large point sources, like power plants or industrial facilities, after which it is injected in the deep underground.

Ever since global warming became an object of major concern, researchers have explored the potential use of CCS. Since the 1980s, feasibility studies were conducted, pilot projects set-up, experiences shared and common technological practices developed. Over time, an 'international CCS community' took shape (Stephens, Hansson, Liu, de Coninck, \& Vajjhala, 2011; Stephens \& Liu, 2012). This community consists of geologists, geophysicists, geochemists, risk assessors, engineers, modellers, economists, climatologists, legal scholars, representatives of major energy companies like Shell, BP or Vattenfall, regulators, representatives of environmental groups, and government officials from fossil-based economies like the United States, the European Union, Australia and China. Members arguably form an 'epistemic' community (Haas, 1992), in the sense that they share a specific set of beliefs: climate change is caused by humans and $\mathrm{CO}_{2}$ is the main greenhouse gas; economic growth will result in more consumption of fossil fuels and increased $\mathrm{CO}_{2}$ emissions; it is socially, politically and economically undesirable (and practically impossible) to drastically limit global use of fossil fuels; CCS is the only option that can drastically reduce the associated $\mathrm{CO}_{2}$ emissions; therefore, large-scale implementation of CCS is necessary for mitigating climate change (Stephens, Hansson, et al., 2011).

Through the working of this community, CCS has gradually turned from an abstract idea into an internationally accepted climate strategy. The promise of CCS was underlined in 2005, when the International Panel on Climate Change published its 'Special Report on 
CCS’ (IPCC, 2005). This synthesis report emphasizes that $\mathrm{CO}_{2}$ can safely be stored in the deep underground. Calculations suggest that the overall costs of mitigating climate change can be significantly reduced if CCS would contribute between 15 and 55\% (!) of the global effort needed by $2100 .{ }^{1}$ A similar message is spread by other influential organizations like the International Energy Agency (IEA), the Global CCS Network and the Carbon Sequestration Leadership Forum. Governments of fossil-based economies like the EU, the US, Australia and China participate actively in such organisations, because they consider CCS to be an important part of their climate strategy. The shared conviction can be summarized as such: CCS is a necessary, safe and feasible element of any cost-effective climate strategy.

Clearly, large-scale implementation of CCS does entail a major societal challenge. To realize significant $\mathrm{CO}_{2}$ emission reductions in the future, multiple demonstration projects are needed in the years to come. A 2009 technology roadmap by the IEA suggested for example that over 3,000 CCS projects are needed worldwide by $2050 .^{2}$ This would cost over $\$ 2,500$ billion and would require 200,000 to 360,000 kilometres of pipelines. Such numbers make some commentators question the practical viability of CCS:

"The IEA figures 360,000 kilometres of pipeline should do the trick. That's nine trips around the earth. Somebody better lock up steel futures, if that's the case" (Wall Street Journal commentary, quoted in Pielke Jr. (2010, p. 134)).

However, one should add that mitigating global warming is considered even more daunting without underground $\mathrm{CO}_{2}$ storage (and thus without continued use of fossil fuels).

Policy papers and technology roadmaps typically express a sense of urgency in developing CCS, as it is meant to have an impact in the period that renewable energy alternatives are still being developed. Feasibility studies suggest that there are no major scientific or technical 'showstoppers' for linking CCS to major sources of $\mathrm{CO}_{2}$. In turn, an influential expectation is that CCS can be rapidly rolled-out (Gibbins \& Chalmers, 2008; Russell, Markusson, \& Scott, 2011). However, the implementation of CCS has significantly slowed down in recent years (Shackley \& Evar, 2012; Scott, 2013). Numerous projects have been cancelled. New power plants are ready to capture $\mathrm{CO}_{2}$, but this does not happen. And worldwide, only a small amount of $\mathrm{CO}_{2}$ is being injected in the deep underground. This is

\footnotetext{
${ }^{1}$ IPCC's Special Report has been influential in bringing credibility to CCS as a viable climate strategy (Markusson, Shackley, \& Evar, 2012). Particularly IPCC's estimation that 15 to $55 \%$ of cumulative mitigation efforts should come from CCS in 2100 is often quoted in policy papers. The IPCC also underlines that there are uncertainties involved in such theoretical calculations, due to real world 'barriers' to CCS implementation. Nevertheless, this section is far less quoted by actors, which can lead to over-enthusiasm regarding CCS (Hansson, 2012).

${ }^{2}$ Source: IEA. (2009). Technology roadmap: Carbon capture and storage. OECD/IEA. More recent roadmaps suggest for example that roughly $15 \%$ of the global $\mathrm{CO}_{2}$ emissions reduction should come from CCS by 2050 , whereas e.g. renewable energy sources should be responsible for roughly $21 \%$ of the required reduction. Source: IEA. (2013). Technology Roadmap: Carbon capture and storage. Paris: International Energy Agency.
} 
the central puzzle of this book: given that CCS is dominantly portrayed as a 'necessary,' 'safe' and 'feasible' climate strategy, how to understand the slowness of its implementation?' Concepts and insights from the field of Science and Technology Studies (STS) will be used to address this question.

Both industrial and environmental groups have, although reluctantly, embraced CCS as part of a realistic climate strategy and an important element of (or bridge towards) a lowcarbon energy future. But sitting on the fault line between the fossil energy regime and the climate change imperative, CCS is also marked by controversy, conflict and the politicization of technology (Markusson, Shackley, \& Evar, 2012). There is for example debate about how to incentivize technology development. Although CCS is expected to make climate mitigation in general more cost-effective, it will add significant (and partly uncertain) costs to individual power plant operations. How to incentivize early investment in CCS? There are also concerns that the mere prospect of CCS will legitimize continued use of fossil fuels and may delay the implementation of renewable energy technologies (de Coninck et al., 2009; Vergragt, Markusson, \& Karlsson, 2011). So, instead of being simply about 'pro or against,' contemporary CCS debates typically centre on the appropriate way of stimulating CCS vis-à-vis other mitigation strategies and on balancing the risks and benefits involved (Corry \& Riesch, 2012). They are thus debates about the governance of CCS.

When I talk of 'governance', this refers broadly to the structures and processes for collective decision-making which affect the pace by which CCS is implemented. Using the term governance emphasizes "that there are (in addition to elected parliamentarians and civil servants) other actors who have a constitutive role in decision-making: i.e. they come to shape and influence decisions taken" (Markusson, Shackley, et al., 2012, p. 125). My analysis will focus specifically on the role of techno-scientific knowledge as actors try to govern the implementation of CCS. Knowledge on the present state of CCS technologies, on the future development of CCS, on the costs and benefits of $\mathrm{CO}_{2}$ capture or on the potential consequences of underground $\mathrm{CO}_{2}$ storage: such knowledge plays an important role in decision-making and in legitimizing collective action on CCS. By focusing on the politics of knowledge, this study aims to add to existing literature on the governance of

\footnotetext{
${ }^{3}$ Obviously, 'slowness' is a relative term. One might argue that CCS has developed rather quickly in comparison to other technologies, like nuclear fusion. One might also argue that CCS did not develop slowly enough when compared to the ideal of a renewable-based energy future. And perhaps in fifty years time, one may conclude that a large-scale, international CCS infrastructure was implemented rather quickly, despite a 'slow' period between 2005 and 2015. My starting point here is that it is surprising that numerous CCS projects were recently cancelled and only a limited amount of $\mathrm{CO}_{2}$ is being injected in the deep underground when compared to contemporary expectations, policy papers and technology roadmaps on CCS. See also: "Expectations for contributions [of CCS to reducing global $\mathrm{CO}_{2}$ emissions] in the coming 10-20 years envisioned by some actors are currently far higher than what developments to date can support" (Nykvist, 2013).
} 
CCS. Other social science literature has fruitfully explored how environmental groups (Wong-Parodi, Ray, \& Farrell, 2008; Corry \& Riesch, 2012), citizens (Shackley, McLachlan, \& Gough, 2004), experts (Hansson \& Bryngelsson, 2009; Evar, 2011; Markusson, Kern, et al., 2012) or industry groups (Davies, Uchitel, \& Ruple, 2013) in general view the risks and benefits of CCS. Such aggregated viewpoints are sometimes used as an explanation for the slowness of CCS implementation, e.g. by pointing out that there are discrepancies in risk perceptions between industry groups and policy-makers (Stigson, Hansson, \& Lind, 2012) or between experts and lay members of the public (Johnsson, Reiner, Itaoka, $\&$ Herzog, 2010). However, it is less studied how democratic societies have tried to deal with such discrepancies thus far and how knowledge on CCS gets negotiated in the process.

As Stephens \& Jiusto (2010), scholars in Sustainability \& Energy research, have for example argued, there is a need to understand the complex relationships and power dynamics which influence society's energy choice and the critical yet never entirely disinterested role that scientists and experts play in suggesting to policy-makers 'the realm of the possible' (see also Evar 2010). The present study aims to address this research need by exploring how knowledge on CCS gets negotiated as actors try to legitimize, incentivize and govern timely action on CCS in specific contexts. This provides clues on why the implementation of CCS has been slow, even though influential studies suggest that CCS is a necessary, safe and feasible climate strategy. Before sketching the analytical perspectives and methodological approach of this book, let me briefly introduce the technical steps of CCS for those unfamiliar with this abatement strategy.

\section{$1.1 \mathrm{CO}_{2}$ CAPTURE AND STORAGE}

CCS starts by capturing large amounts of $\mathrm{CO}_{2}$. This is not done by filtering it from the atmosphere. ${ }^{4}$ Instead, $\mathrm{CO}_{2}$ is collected at point sources. Oil refineries, fertilizer plants, steel works, cement factories and paper mills all produce $\mathrm{CO}_{2}$, which can be collected at relatively low cost. The capture process is more difficult for coal- or gas-fired power plants. There are over 4000 power plants worldwide, which produce over 10,000 $\mathrm{Mt} \mathrm{CO}_{2} /$ year in total. ${ }^{5}$ Several techniques have been developed to capture $\mathrm{CO}_{2}$ from these facilities. $\mathrm{CO}_{2}$ may be separated from the flue gas of power plants (known as 'post-combustion capture'). Flue gas

\footnotetext{
${ }^{4}$ Techniques to capture $\mathrm{CO}_{2}$ directly from ambient air are being developed too (e.g. Keith, 2009). As this is not the main approach advocated by the international CCS community, it is outside the scope of this book.

${ }^{5}$ A $1000 \mathrm{MW}$ pulverized coal-fired power plants emits 6 to $8 \mathrm{Mt} /$ year, while a gas-fired power plants emits about half that amount (Herzog, 2009, p. 268).
} 
consists of nitrogen, oxygen, water vapour and a relatively small amount of $\mathrm{CO}_{2}$. This $\mathrm{CO}_{2}$ can be 'scrubbed' from the gas stream using an amine solution. After leaving the scrubber, the solution is heated to release the $\mathrm{CO}_{2}$ and the amines can be re-used. The downside of this technique is that it requires large and expensive equipment and a considerable amount of energy. A power plant with CCS requires roughly 10 to $40 \%$ more energy than a plant without CCS. Capture efficiency can be greatly increased by using concentrated oxygen instead of air for the combustion. This process is known as 'oxy-fuel combustion.' However, the production of oxygen is expensive and requires a lot of energy too. Another set of capture techniques is known as 'pre-combustion capture.' This requires a different power plant all together. Fossil fuel is gasified with oxygen, resulting in hydrogen and carbon monoxide. Carbon monoxide is then made to react with steam, resulting in $\mathrm{CO}_{2}$ and more hydrogen. The hydrogen is used to fuel a gas turbine. The $\mathrm{CO}_{2}$ can be captured in a relatively pure stream. ${ }^{6}$

With this short overview, I want to highlight several things. First, $\mathrm{CO}_{2}$ capture involves multiple steps and techniques, some of which are further developed than others. The IPCC (2005) for example makes a distinction between 'existing' and 'emerging' technologies used in post-combustion, oxy-fuel or pre-combustion installations. Second, it is not easy to capture $\mathrm{CO}_{2}$ from existing power plants. They will have to be retrofitted. Therefore, the expectation is that CCS will first be applied to industrial facilities and to new power plants (designed with CCS in mind). Third, large-scale $\mathrm{CO}_{2}$ capture entails significant and partly uncertain costs, in terms of money and energy. Much research has therefore focused on increasing the efficiency of, and gaining experience with, this step in the CCS chain. By 2005, influential bodies like the International Energy Agency and International Panel on Climate Change projected that commercial-scale capture from coal-fired power plants was roughly a decade away. ${ }^{7}$ In the mean-time, $\mathrm{CO}_{2}$ could already be captured at e.g. oil refineries or new coal gasification plants.

Once captured, $\mathrm{CO}_{2}$ can be compressed, transported and injected in the deep underground. From the 1980s onwards, researchers have studied the feasibility of several storage schemes. ${ }^{8}$ Important criteria were that $\mathrm{CO}_{2}$ storage should provide enough emission reductions to have an impact on global warming; it should be cost-effective; and it should have an acceptably small environmental impact. Several schemes failed to meet these criteria.

\footnotetext{
${ }^{6}$ I do not mean to suggest that this is a simple step. Capture may be done through amines solutions, membranes or solid sorbents. According to power plant operators, capturing $\mathrm{CO}_{2}$ at commercial scale continues to include numerous technical challenges and uncertainties regarding costs and performance (e.g. van den Broek, Hoefnagels, Rubin, Turkenburg, \& Faaij, 2009).

${ }^{7}$ This expectation presumed that numerous CCS demonstration projects would be set-up in the meantime. As said, many of these projects have been cancelled in recent years.

${ }^{8}$ See for example Steinberg et al. (1984), Blok, Hendriks \& Turkenburg (1989) or Holloway (1996).
} 
Storage in salt domes was for example considered "too expensive to be practical." Re-using $\mathrm{CO}_{2}$ in e.g. soft drinks or horticulture greenhouses was seen as insufficient. A suggestion made by the Editor of ChemTech Magazine ("If we've gone through the trouble of separating the $\mathrm{CO}_{2}$, why not simply follow Mother Nature's lead and use the $\mathrm{CO}_{2}$ to generate useful or recyclable biomass products?") was illustratively mocked by a representative of US Department of Energy at a CCS conference:

"I have some bad news for you Mr. Gelbein, your 'great idea' is seriously flawed. We are talking here about storing billions of tons of $\mathrm{CO}_{2}$. Your idea, even if commercially successful, and that's a huge if, could only fix a fraction of that amount. Unfortunately, there are still many 'experts' like Mr. Gelbein out there.”10

$\mathrm{CO}_{2}$ can also be injected in the deep ocean. There is a continuous exchange of around 90,000 $\mathrm{Mt} \mathrm{CO}_{2} /$ year between the atmosphere and the ocean surface. Some portray ocean injection of $\mathrm{CO}_{2}$ as simply an acceleration of this natural process. There are several problems though. First, it is unclear whether and how re-entry of the injected $\mathrm{CO}_{2}$ to the atmosphere can be sufficiently delayed to actually mitigate climate change. Second, when $\mathrm{CO}_{2}$ dissolves in water, this results in an acid mixture. The environmental effects (e.g. on the ecosystems and the physiology of marine animals) were long considered uncertain. In turn, experiments with ocean storage have remained relatively small-scale. ${ }^{11}$ The gaze of the international CCS community has therefore turned to the deep underground.

Broadly speaking, two main storage locations are envisaged: (i) water-filled layers called 'aquifers' and (ii) depleted gas fields or nearly depleted oil fields. Studies indicate that these formations can accommodate over 2,000,000 Mton $\mathrm{CO}_{2}$ worldwide. ${ }^{12}$ For comparison: IPCC scenario studies indicate that around 1,200,000 Mton should be reduced globally by $2100 .^{13}$ Let me briefly discuss the two storage options, explaining their perceived advantages and drawbacks.

\footnotetext{
${ }^{9}$ IEA. (1994). Scoping study: Energy and environmental technologies to respond to global climate change concerns. IEA/OECD, p. 177.

${ }^{10}$ Bergman, P. (1998). Geological sequestration of $\mathrm{CO}_{2}$ : A status report. In B. Eliasson, P. Riemer, \& A. Wokaun (Eds.), Proceedings of the 4th International Conference on Greenhouse Gas Control Technologies (pp. 169-174). Interlaken (Switzerland): Pergamon.

${ }^{11}$ For early studies on this approach, see e.g. Marchetti (1977) or Cole, Stegen \& Spencer (1993). An update can be found in Herzog et al. (2000) or Adams \& Caldeira (2008). When talking of CCS in the remaining chapters, I will not include efforts to inject $\mathrm{CO}_{2}$ in the deep ocean. As a form of geo-engineering, ocean disposal invites different normative, scientific and governance debates compared to geological disposal schemes (Keith, 2000; Poumadère, Bertoldo, \& Samadi, 2011).

${ }^{12}$ Source: IPCC, 2005, p. 12. Oil and gas fields can accommodate between 675,000 and 900,000 Mton $\mathrm{CO}_{2}$. Estimations on storage capacity in aquifers range from 1,000,000 to possibly 10,000,000 Mton $\mathrm{CO}_{2}$, depending on assumptions made about criteria for site selection (e.g. Bachu et al., 2007; Chadwick et al., 2010).

${ }^{13}$ This is an early estimation, quoted by Turkenburg (1992).
} 


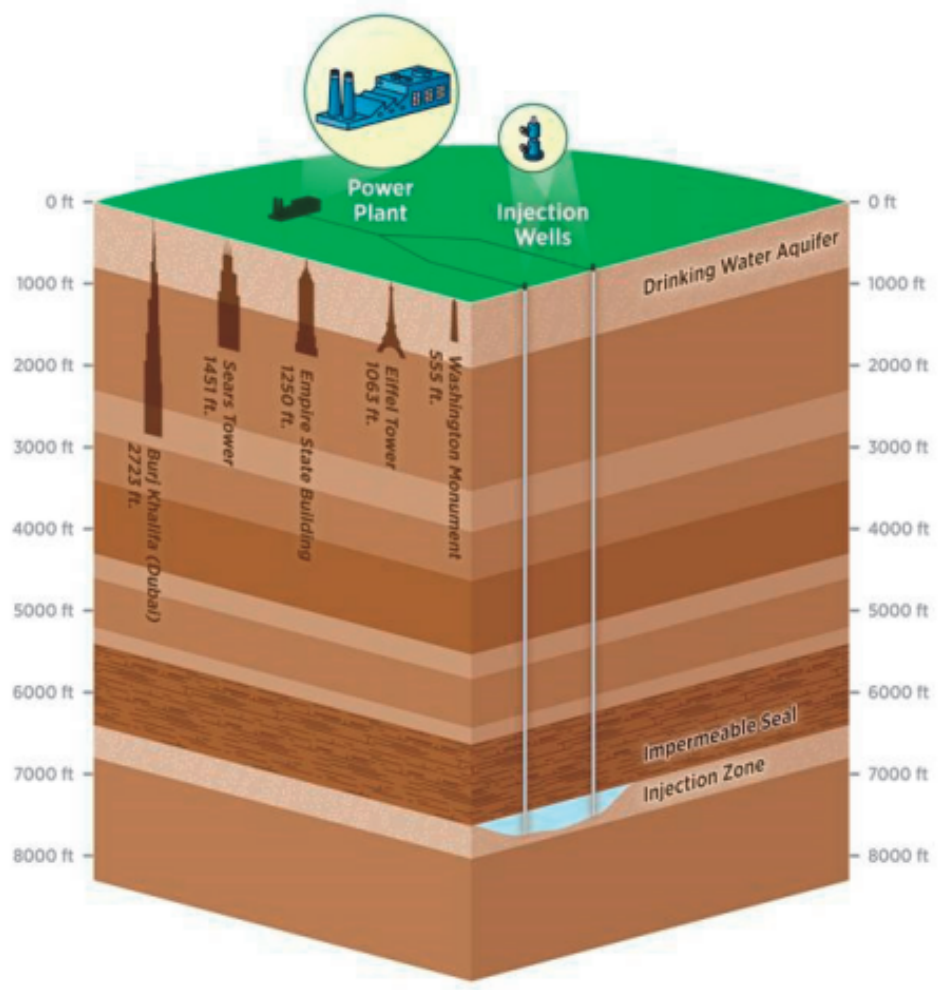

Figure 1: Schematic overview of CCS

Source: US Environmental Protection Agency

Aquifers are permeable layers in the deep underground, consisting mostly of sand or rock. Miniscule holes in this material allow for a flow of fluids and gases. They are therefore filled with saline water, in which minerals are dissolved. Aquifers can be found all over the world, although their thickness and depth vary significantly. Some aquifers have an impermeable layer on top of them. This 'cap rock' can act as a seal, trapping gas or liquids in the aquifer. ${ }^{14}$ As the injected $\mathrm{CO}_{2}$ is more buoyant than the water present in an aquifer, it will move upwards and eventually be trapped underneath cap rock. Part of the $\mathrm{CO}_{2}$ moves horizontally and could potentially reach areas of the aquifer without sufficient cap rock.

\footnotetext{
${ }^{14} \mathrm{CO}_{2}$ is typically injected at depths greater than $800 \mathrm{~m}$. At those depths, $\mathrm{CO}_{2}$ is no longer in gas but in supercritical, liquid phase (allowing more $\mathrm{CO}_{2}$ to be stored). To achieve this phase at shallower depths, one would have to 'over pressurize' the reservoir, which is considered dangerous because it could fracture the cap rock after which concealing properties can no longer be guaranteed (Holloway \& Savage, 1993, p. 926; see also Holloway \& van der Straaten, 1995). An additional advantage of injecting $\mathrm{CO}_{2}$ at considerable depth is that the chance of leakage into freshwater supplies is limited (Riemer \& Ormerod, 1995).
} 
This is not necessarily problematic, as $\mathrm{CO}_{2}$ is expected to travel only horizontally at a slow pace, resulting in long residence times. In this period, several other mechanisms are expected to keep the $\mathrm{CO}_{2}$ trapped in the underground.

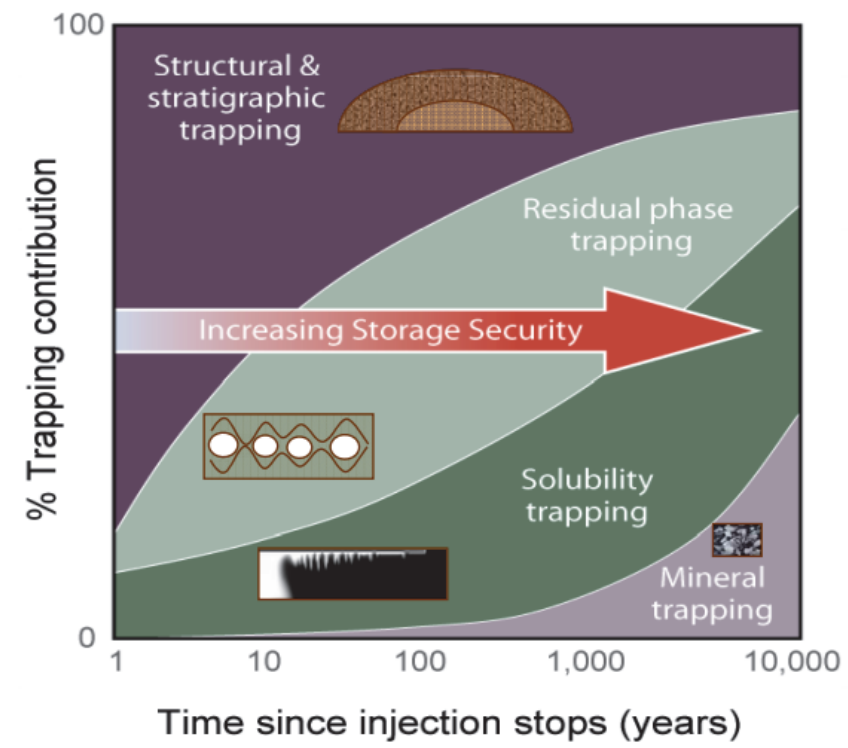

Figure 2: Relative contribution of various trapping mechanisms.

Source: Benson, S. (2009). 'CCS in deep geological formations,' Public workshop at Stanford University Global Climate \& Energy Project.

A graph like Figure 2 is often used in CCS communications to indicate the effect of the various trapping mechanisms. Initially, the $\mathrm{CO}_{2}$ is kept in the deep underground primarily because it is trapped underneath cap rock. Over time though, this cap rock (which could fracture if placed under too much stress) becomes less important. The injected $\mathrm{CO}_{2}$ replaces water, causing the porous rock formation to act as a sponge (residual trapping). Part of the $\mathrm{CO}_{2}$ dissolves in the saline water. The resultant mixture is denser than the surrounding fluids and gradually sinks to the bottom of the aquifer, instead of moving up (solubility trapping). As $\mathrm{CO}_{2}$ dissolves in saline water, an acid mixture is formed. This mixture reacts, on a long timescale, geochemically with minerals present in the rock formation, thus forming solid carbonates (mineral trapping). Again, graphs like Figure 2 above are meant to emphasize that the security of underground $\mathrm{CO}_{2}$ storage only increases over time.

In the 1980s and 1990s, trapping mechanisms were only qualitatively understood. Researchers were struggling with a lack of experience and of suitable data. In turn, sitespecific studies and demonstration projects were set-up to turn aquifer storage "from an interesting insurance option to an off-the-shelf deployable technology in a 10 to 15 year 
time horizon." 15 The project which is most often referred to in CCS literature is the Norwegian Sleipner Aquifer $\mathrm{CO}_{2}$ Storage project. In 1996, Statoil decided to inject $\mathrm{CO}_{2}$ in an aquifer, lying roughly 1000 meters below the seabed. SACS was heralded as a "milestone in industrial history." ${ }^{16}$ It brought together an international team of experts with knowledge of geology, geochemistry, geophysics, reservoir engineering and monitoring. By pooling existing knowledge together (i.e. on the initial stress and temperature differences in the formation), a preliminary storage model was made. Simulations indicated that some of the $\mathrm{CO}_{2}$ could travel up to $3 \mathrm{~km}$ from the injection point, to parts of the underground that were less known. This meant that minor $\mathrm{CO}_{2}$ leakage could not be excluded beforehand. Importantly though, simulations were only the first step in an iterative loop. A few years after injection started, seismic images and other monitoring exercises were done to check whether the $\mathrm{CO}_{2}$ behaved as expected. This data was then used to update the model of the underground and to make new predictions. The iterative loop had a double function. First, it showed that monitoring techniques 'worked': they could measure even relatively small $\mathrm{CO}_{2}$ accumulations, so major leakage would have been detected too. And with confidence in the quality of the monitoring techniques established, researchers could also state with confidence that there was "no leakage" in the Sleipner project (Arts, Chadwick, \& Eiken, 2004).

Historian of Science Naomi Oreskes reminds us that models of complex systems like the Utsira aquifer can never be completely validated or verified (Oreskes, 1998, 2000; Oreskes, Shrader-Frechette, \& Belitz, 1994). Judgment on the adequacy of models is always tied up with judgment on the normative and social implications of what one expects to model (and thus on how one assesses the implications of being (slightly) wrong). From the 1990s onwards, a lot of information has been gathered from other CCS demonstration projects like BP's In Salah project in Algeria and from natural and industrial analogues for $\mathrm{CO}_{2}$ storage (e.g. Benson, Hepple, Apps, Tsang, \& Lippmann, 2002; Benson, 2007). This has made the international CCS community confident that $\mathrm{CO}_{2}$ can safely be stored in selected aquifers, uncertainties notwithstanding. The iterative loop between modelling and monitoring is best understood as a tool for decision-making under uncertainty. It helps to decide whether (or: when) the risks involved in a CCS project are acceptably small.

\footnotetext{
${ }^{15}$ Source: Webster, I. (1995). IEA Greenhouse Gas Programme: Continued international collaboration. Energy Conversion and Management, 36(6-9), p. 867. For many, knowledge and experience gained in early demonstration projects allowed for such a general assessment by 2005 , as reflected by the IPCC Special Report on CCS.

${ }^{16}$ IEA-GHG. (1997). Sleipner carbon dioxide storage workshop (25-26 November 1997, Trondheim, Norway). IEA Greenhouse Gas R\&D Programme, p. 4.
} 

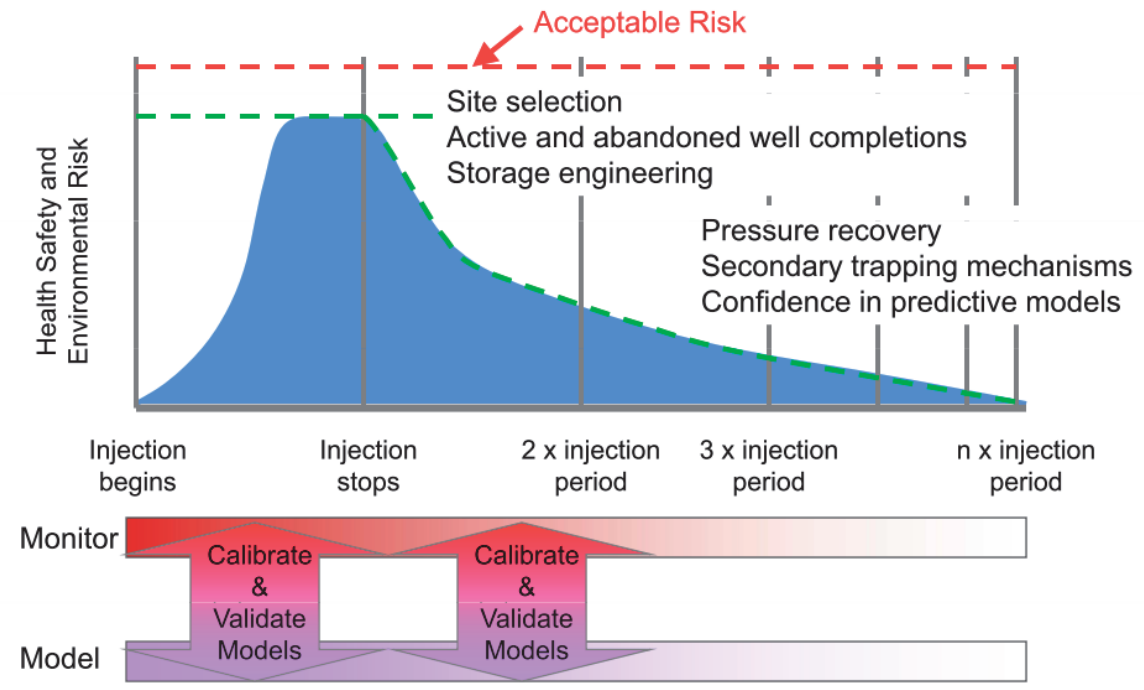

Figure 3: Long term risk profile of CCS.

Source: Benson, S. (2009). 'CCS in deep geological formations,' Public workshop at Stanford University Global Climate \& Energy Project.

A graph like Figure 3 is often used in CCS communications to illustrate this. It suggests that health, safety and environmental risks decline over time, as monitoring helps to improve the predictive models and secondary trapping mechanisms kick in.

The risk profile is somewhat different when injecting $\mathrm{CO}_{2}$ in depleted gas or oil fields. Although their estimated storage capacity is smaller compared to aquifers, these formations have several advantages. First, reservoir properties are often well-known, since a lot of information has been gathered during extraction. Second, the presence of a sealing cap rock is considered to be 'proven over millions of years.' The reasoning is simple: without rock covering the reservoir, there would not have been an accumulation of natural gas or oil in the first place. ${ }^{17}$ Third, wells and infrastructure are often already in place, which can be reused for $\mathrm{CO}_{2}$ transport and injection. It should be noted that abandoned wells are considered the most likely pathway for leakage. However, several techniques are available to reduce this risk, like checking conditions of the wells, placing monitoring devices or plugging wells with a thick concrete layer (known as a 'pancake plug'). Provided that storage locations are properly selected and managed, it is considered highly unlikely that the injected

\footnotetext{
${ }^{17}$ This 'rule of thumb' is often referred to in CCS literature. See for example (Ormerod, Webster, Audus, \& Riemer, 1993; Holloway, 1996, p. 1150; Freund \& Ormerod, 1997).
} 
$\mathrm{CO}_{2}$ will leak back to the atmosphere. ${ }^{18}$ Injecting $\mathrm{CO}_{2}$ in oil fields has an additional advantage: it can help to maintain reservoir pressure and thus increases the oil production. This is known as Enhanced Oil Recovery. EOR has been in commercial use since the 1970 s. In the US alone, more than $2,500 \mathrm{~km}$ of pipeline is in place. In 2001, these pipelines were transporting over $33 \mathrm{Mt} \mathrm{CO}_{2} /$ year. ${ }^{19}$ Most of this was coming from natural reservoirs. However, EOR can also be linked to anthropogenic sources of $\mathrm{CO}_{2}$ so that it becomes a climate strategy.

What to take away in the context of this thesis? The deep underground provides ample space for $\mathrm{CO}_{2}$ storage. Parties within the international CCS community are confident that the risks involved in individual projects can be reduced to a point where they are acceptably small (that is: comparable or lower than the risks of established practices like natural gas storage and underground disposal of acid gas). Few parties consider CCS to be a 'silver bullet' or a preferred climate approach. However, influential studies suggest that large-scale implementation of CCS is a necessary, safe and feasible element of any cost-effective climate strategy. ${ }^{20}$

\subsection{CCS AS AN EMERGING SOCIO-TECHNICAL SYSTEM}

In the above, I have sketched some of the steps involved in CCS. It should be noted though that 'CCS' is an ambiguous term. Besides capturing and storing $\mathrm{CO}_{2}$, CCS requires a large physical infrastructure for transportation and monitoring too. Additionally, it will require an extensive bureaucratic infrastructure to account for the location of large quantities of $\mathrm{CO}_{2}{ }^{21}$ So, CCS is hardly a single entity. It involves numerous steps, practices and technologies. Some are more advanced than others. This makes it hard to speak 'in general' about

\footnotetext{
${ }^{18}$ Leakage to the atmosphere is not the only risk when injecting $\mathrm{CO}_{2}$ in the deep underground. It could for example trigger seismic activity too. Damen et al. (2006) and Bachu (2008) provide an overview of the health, safety and environmental risks involved in CCS.

${ }^{19}$ IEA-GHG. (2001). Putting carbon back in the ground. IEA Greenhouse Gas R\&D Programme, p.14.

${ }^{20}$ See e.g. IPCC. (2005). Special Report on Carbon Dioxide Capture and Storage. Cambridge University Press. And: IEA. (2008). $\mathrm{CO}_{2}$ Capture and Storage - A key carbon abatement option. International Energy Agency, Paris. Or: ZEP. (2013). CCS - An essential technology to reconcile EU energy security with climate objectives. Zero Emissions Platform, The Hague.

${ }^{21}$ Especially in a context where companies have to pay if they fail to properly store their $\mathrm{CO}_{2}$ emissions, it is important to account for the location of huge quantities of $\mathrm{CO}_{2}$ in a trustworthy manner. It is not yet clear what the required 'information infrastructure' for this will look like. Trade-offs will have to be made, as every additional check or monitoring device only adds to the costs of CCS.
} 
$\mathrm{CCS}^{22}$ Is CCS a new or an existing technological practice? Is CCS adequately demonstrated or not? These are important questions in governance debates, but answers depend on what 'CCS' is meant to refer to in a particular context. Classifications and words are not neutral in this respect. When talking of $\mathrm{CO}_{2}$ capture and storage, other practices like nuclear waste storage may act as a rhetorical trope, suggesting e.g. that leakage is unacceptable. But not everyone is convinced that this is the right association. From a climate perspective, it may be important to also select those storage locations which could leak a little bit, as long as re-entry to the atmosphere is sufficiently delayed. ${ }^{23}$ And does Enhanced Oil Recovery qualify as CCS, when part of the injected $\mathrm{CO}_{2}$ leaves the oil reservoir through the production well? Therefore, some prefer to speak of ' $\mathrm{CO}_{2}$ sequestration' or ' $\mathrm{CO}_{2}$ removal' instead of ' $\mathrm{CO}_{2}$ storage.' Others try to push the term CCUS, including the Utilization of $\mathrm{CO}_{2}$ (e.g. in horticulture or carbonated beverages). Again, this has important governance implications: different rules and regulations apply when $\mathrm{CO}_{2}$ is classified as a hazardous waste or as a commodity. Finally, it makes little sense to discuss 'CCS' in isolation. It is not a set of stand-alone technologies, but an abatement strategy which can be applied to various facilities, ranging from hydrogen factories to existing power plants and from coal-fired to biomass-fired power plants (where application of CCS could result in 'negative emissions'). All options invite different governance discussions.

In this book, I will use 'CCS' as a container term, referring to those socio-technical systems which are meant to sequester $\mathrm{CO}_{2}$ emissions from fossil fuel usage by injecting it in the deep underground. I will add further nuance (e.g. by specifying the precise steps or technologies used in a particular project) when I feel that it is necessary to understand the dynamics of a debate or the positions taken by actors. My depiction will focus less on the development of specific CCS technologies, but will mostly touch on those structures, processes and considerations which govern the implementation of CCS.

\subsection{RESEARCH DESIGN AND METHODOLOGY}

Starting point of my analysis is the observation that there is a dominant discourse pushing for CCS. Few consider underground $\mathrm{CO}_{2}$ storage to be an attractive climate strategy. So,

\footnotetext{
${ }^{22}$ I take this point from Russell, Markusson \& Scott (2011).

${ }^{23}$ The IPCC (2005) for example works with 'acceptable leakage rates'. Like other elements of this special report, such rates were negotiated in view of two demands: scientific rigor and policy relevance (Narita, 2012). Some commentators argued for example that a low leakage rate would provide a sufficiently large margin of error to reassure the public and stakeholders, while a 'zero leakage' demand could stifle innovation (Shackley \& Gough, 2006, p. 287).
} 
actors typically draw on knowledge regarding the (i) necessity, (ii) safety and (iii) feasibility of CCS in order to coordinate, legitimize and govern timely implementation of CCS. Nevertheless, this implementation has been slow in recent years. To understand this situation, each chapter is based on a 'hard' case. This case provides a context where respectively the necessity, safety and feasibility of CCS seemed almost self-evident and where few would question whether CCS could be implemented. But they are also contexts where knowledge on CCS became heavily contested and where surprisingly little (or no) $\mathrm{CO}_{2}$ was stored underground.

In this thesis, I will use three analytical perspectives to bring different aspects of the governance of CCS in focus. These perspectives are 'socio-technical imaginaries', 'framing' and 'boundary work' (see table 1). Affected publics, end users and interest groups are increasingly involved in attempts to make the governance of energy reform (and innovation in general) more democratic. Increasingly, the various claims that these groups use-pleas for energy policies, support or rejection of concrete energy projects, proposals for regulation-are legitimized by referring to techno-scientific knowledge. Actors feel the need for, or are invited to provide support for their viewpoints through evidence. Put differently, contemporary democratic societies typically rely on a public display of rationality when legitimizing collective action-also on energy reform. The three analytical perspectives have in common that they all focus on the politics of knowledge in governing CCS.

A perspective on 'energy imaginaries' helps to understand how specific energy policies and specific CCS visions take shape in a particular context (Chapter 2). Energy imaginaries play an important role in the governance of CCS. They suggest to actors what a collective energy future might (and should) look like, who is responsible for realizing this future and how the associated costs and benefits should be distributed. Energy imaginaries alone cannot account for the way that decisions on concrete CCS projects are made though. For this, a perspective on 'frames' is introduced (Chapter 3). As actors try to come to an authoritative decision on a project, they rely on a specific framing of the problem at hand. Frames help to suggest what knowledge on CCS should be taken into account and which experts should be consulted. As my analysis will show, frames are partly structured by existing rules and regulations. But such regulations are not fixed. In fact, new regulations are being developed worldwide in order to spur and ensure commercial-scale application of CCS. To understand how such regulations are legitimized, a perspective on 'boundary work' is helpful (Chapter 4). Regulations are often portrayed as an alternative or supplement to energy policies, in the sense that they are based on techno-scientific evidence rather than sociopolitical considerations. But this distinction is hardly straightforward. It is worth investigating how actors try to draw a boundary between 'techno-scientific evidence' and 'sociopolitical considerations' as they try to put appropriate regulations in place. My central claim 
is that the three analytical perspectives together (i) help to understand what role knowledge plays in the governance of CCS and (ii) provide clues on why the implementation of CCS has been slow.

Table 1: Outline of the thesis

\begin{tabular}{lll}
\hline Analytical perspective & Case & Central theme \\
\hline $\begin{array}{l}\text { Socio-technical energy } \\
\text { imaginaries }\end{array}$ & $\begin{array}{l}\text { Development of climate and energy policies } \\
\text { (the Netherlands and Rotterdam) }\end{array}$ & Necessity \\
Frames and overflows & $\begin{array}{l}\text { Decision-making process on a concrete CCS project } \\
\text { (Barendrecht, NL) }\end{array}$ & Safety \\
$\begin{array}{l}\text { Boundary work and } \\
\text { demonstrator's regress }\end{array}$ & $\begin{array}{l}\text { Dynamics of regulatory process } \\
\left(\mathrm{CO}_{2} \text { standard for new coal-fired power plants, US) }\right.\end{array}$ & Feasibility \\
\hline
\end{tabular}

To be clear, the analytical perspectives are not exclusively tied to the central themes of the chapters. Imaginaries, frames and boundary work play a role in each of the studied casesand, I suggest, in all cases of CCS — but I have foregrounded one specific approach in each chapter for reasons of brevity and comprehensiveness. A complete analysis of one single case would need to pay attention to all three aspects: the dominant socio-technical imaginary, the framing of the issues, and the boundary work for creating appropriate regulation.

My qualitative research is based on two types of material. Primary documents were selected for each case. Relevant material differed considerably from chapter to chapter. Chapter 2 draws mainly on policy (advisory) documents on Dutch energy reform and climate action. Chapter 3 draws on safety studies, public reports and minutes of meetings that were produced during the Barendrecht controversy. Chapter 4 is mainly based on an extensive body of public comments, minutes of meetings and technical reports that was produced during EPA's standard-setting process. Collected documents were chronologically ordered and coded, partly by hand and partly by using computer program Atlas.Ti. A different coding scheme was developed for each chapter. At times, I was swamped by the number of documents available on the selected cases. The regulatory standard of Chapter 4 invited for example more than 2 million public comments. Of course, it is impossible to analyze all of this material. To supplement and guide the document analysis, I conducted over 50 semistructured interviews between 2011 and 2013 (see Appendix A for an overview). Interviews helped to familiarize myself with the main points of contestation in the selected cases and helped to select relevant sources. Furthermore, interviews provided valuable insight in those considerations and negotiations that were not mentioned in the studied documents.

Respondents were selected because they had been involved in the selected cases or because they work on CCS implementation in the Netherlands or the United States. A snowballing method was used, asking interviewees to identify other important groups or persons that 
played a role in the selected cases. I have spoken with e.g. geophysicists, geochemists, reservoir engineers, risk assessors, former ministers, civil servants, business developers, lobbyists, knowledge brokers, environmentalists and members of local actions groups. An interview topic guide was used to explore the respondent's background, her/his views on the desirable future of CCS (values), the risks, benefits and uncertainties involved in CCS (knowledge) and steps taken and perceived barriers towards realizing the desired future (actions). This protocol was adapted for each interview, so that in-depth knowledge could be gained. For example, I spoke at length with a reservoir engineer to gain an understanding of the long-term risk of $\mathrm{CO}_{2}$ leakage along abandoned injection wells (which is generally considered the most likely pathway for leakage). I also interviewed the Program Director of the Dutch CCS Research Program, who informed me about the consortium's scientific work to support CCS in the Netherlands. Obviously, the questions asked were different in both interviews. Interviews took between forty-five minutes and two and a half hours each. They were recorded and transcribed so that they could be analyzed later. I do not claim that I have spoken to all parties involved in the governance of CCS; I conducted interviews to the point where I felt that I knew enough to understand the dynamics of the selected cases. When giving direct quotations, I have asked the respondent for authorization and for her/his views on my interpretation and my English translation of their words. Ultimately, the interpretation is my own and I am responsible for the structure of my narrative and my representation of the often heated debates (e.g. when it comes to highlighting some details, while leaving others untold).

I realize that this thesis may be read by different audiences: those interested in CCS, those interested in STS and those interested in both. This is then also the place to position myself as a researcher. I visited three CCS symposiums ${ }^{24}$ and spoke to numerous people within the 'CCS community.' This made me familiar with the general discourse on CCS. At the same time, I do not consider myself a member of that epistemic community and I try to critically engage with the dominant discourse. Importantly, this does not mean that I claim that CCS is unnecessary, unsafe or unfeasible (nor do I claim that it is necessary, safe or feasible). Rather, my claim is that one can better understand the tensions, challenges and politics involved in the implementation of CCS if its necessity, safety and feasibility are not taken for granted, but are treated as contingent elements which need to be explained. I have focused on controversial cases because this provides rich material. This methodological choice may give some readers the impression that a lot is still unknown about CCS. To make up for this, I make rather extensive use of footnotes to sketch the broader context and refer to often-quoted studies on CCS.

\footnotetext{
${ }^{24}$ I attended the $5^{\text {th }}$ National CCS Symposium (Van Nelle Fabriek, Rotterdam 2011), the Accelerating CCS Conference (London, 2012) and the $7^{\text {th }}$ National CCS Symposium (Rai, Amsterdam 2014) and watched several online webinars of the Global CCS Institute on recent CCS developments.
} 


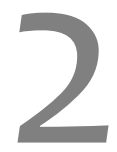

Imagining a collective energy future, constructing necessity 
Over the past decades, the Dutch climate strategy has come to focus on three main elements: saving energy, switching to renewable energy sources and cleaning fossil energy use (in Dutch: 'Schoon Fossiel'). This third element will require a large-scale infrastructure for capturing, transporting and storing the $\mathrm{CO}_{2}$ emissions produced by e.g. power plants, oil refineries or hydrogen factories. Schoon Fossiel has been described as one of the pillars underneath Dutch energy reform and as a necessary step in the transition towards a sustainable energy future. ${ }^{25}$ However, Schoon Fossiel still remains a fictive pillar. Progress has significantly slowed down in recent years. After a small-scale pilot project was conducted on the North Sea, larger demonstration projects were cancelled or delayed. By now, it is clear that early expectations on CCS will not be met in the Netherlands. How to understand this, given that CCS is still commonly portrayed as a necessary element of the Dutch energy future?

Scholars in the field of STS have gone out of their way to debunk strong notions of technological determinism, according to which technological chance follows a fixed trajectory of constant improvement while maintaining a singular function and meaning (e.g. Bijker, Hughes, \& Pinch, 1987; Bimber, 1990). Such studies also criticize the idea that existing socio-technical systems (like our fossil-based system of electricity production and distribution) force societies to continue using them. ${ }^{26}$ Closure on, and path-dependency of, a dominant technical design is always conditional. Importantly, Wyatt (2008) invites us to not merely debunk or dismiss the still-dominant idea of 'necessity' in technological development, but to study instead how this idea is constructed and what (justificatory) role it plays in structuring contemporary debates on, in the present case, energy reform and climate action. My starting point is therefore that the 'necessity' of CCS cannot be understood in terms of technical feasibility and cost-effectiveness alone. It is hardly self-evident that a developed nation like the Netherlands (having long prided itself for being an innovative international frontrunner on climate action) would strive to develop Schoon Fossiel, while for example the Danish government aims to realize a sustainable energy system which is based on renewable energy sources alone. To understand such differences in national policies on energy reform, Jasanoff $\& \operatorname{Kim}(2009$, p. 141) suggest that an analyst "needs to

\footnotetext{
${ }^{25}$ See for example: Rijksoverheid (2011). 'Klimaatbrief 2050 - Uitdagingen voor Nederland bij het streven naar een concurrerend, klimaatneutraal Europa', Kabinetsaanpak Klimaatbeleid, November 2011. Numerous other instances will be discussed later in this chapter.

${ }^{26}$ As Langdon Winner (1993) put it in a critical review of STS literature: "Social constructivist interpretations of technology emphasize contingency and choice rather than forces of necessity in the history of technology (pp. 3667). I too will argue that the 'necessity' of CCS was the result of contingency and choice in Dutch energy policies, whilst acknowledging that such choices were influenced by e.g. the existing energy system and the presence of depleted gas fields underneath the Netherlands.
} 
invoke not only the material and organizational resources that states deploy but also the imaginative resources with which they relate such policies to the public good."

This chapter will analyze the emergence of Schoon Fossiel on the Dutch policy agenda. Central questions are: What is the imagined relation between societal and technological progress guiding Dutch CCS projects and policies? How is responsibility for climate action and energy reform distributed? And what tensions does this imaginary entail for the implementation of CCS? I will argue that the energy imaginary which provides inspiration for collective visions of large-scale CCS also restricts the ways by which such visions can be realized in the Netherlands.

\subsection{STUDYING SOCIO-TECHNICAL IMAGINARIES}

Imaginaries can be defined as visions of feasible, desirable futures; they are representations both of how things could and should be (Fairclough, 2010). Importantly, imaginaries are not neutral. They are performative: by linking aspects of the present with preferred futures, imaginaries also create the conditions to achieve these futures (Levidow \& Papaioannou, 2013, p. 38; Nowotny, 2014). ${ }^{27}$ Imaginaries tend to come with a specific, but often implicit notion of the imagined audience too. This is most evident in political imaginaries, which provide the fictions necessary to shape and sustain political communities (Anderson, 1983; Ezrahi, 2012). The same is arguably at play in economic imaginaries, depicting a community of shared economic interests, as is for example drawn upon in narratives of the EU being a 'knowledge-based economy' (Levidow, 2013). STS scholarship has underlined that political imaginaries of modern democracies like the EU tend to be closely intertwined with developments in science and technology (Felt \& Wynne, 2007). This can be illustrated by highlighting two features. First, scientific knowledge plays a key role in making 'collective' decisions in modern democracies, allowing interventions to be portrayed as rational, accountable and virtually non-political (Ezrahi, 1990, 2004). Second, modern democracies tend to focus strongly on supporting innovation. This policy approach is typically legitimized by portraying citizens (as a seemingly homogenous community) as the ultimate beneficiaries of perpetual techno-scientific change (Wynne, 2007; Nowotny, 2014).

Given the importance of science and technology in modern democracies, Jasanoff and Kim (2009) argue that studying sociotechnical imaginaries is particularly fruitful. Sociotech-

\footnotetext{
${ }^{27}$ Similar points have been made about the role of more concrete expectations and visions in technological development (van Lente, 1993; Borup, Brown, Konrad, \& Van Lente, 2006; see also Hansson, 2012 on the role of expectations in the development of CCS specifically).
} 
nical imaginaries articulate feasible futures by providing visions of what is good, desirable and worth attaining for a political community (Ibid., p. 123). Their performativity can arguably best be understood as a process of co-production. On the one hand, "sociotechnical visions, and the policies built upon them, have the power to influence technological design, channel public expenditure and justify the inclusion or exclusion of citizens with respect to the benefits of technological progress" (Ibid., p. 120). On the other hand, technological systems reinforce particular imaginations of feasible futures, public good and nationhood (see also Hecht, 1998). Sociotechnical imaginaries thus play a crucial role in the way that new technologies get envisioned, practiced, assessed and governed. They warn against risks that might accompany innovation if it is pushed either too slow or too fast. Turning the gaze to sociotechnical imaginaries is meant to overcome a short-coming in STS literature too. STS has traditionally focused on the production of scientific knowledge claims (Latour \& Woolgar, 1986; Jasanoff, Markle, Peterson, \& Pinch, 1995), the design of technological artefacts (Bijker, 1995; Bijker et al., 1987), the assessment of risks and benefits (Wynne, 1987) and the dynamics involved in science-for-policy (Jasanoff, 1987, 1990 ). However, it is rarely asked why states support (and how they legitimize) particular forms of science and technology (Jasanoff \& Kim, 2009, p. 120; compare Nowotny, 2014). Looking at socio-technical imaginaries provides valuable insights on this matter.

Given their broad meaning and function, it may help to also clarify what 'sociotechnical imaginaries' are not (based on Jasanoff \& Kim, 2009). First, they are not the same as master narratives. Where master narratives are often extrapolated from past events and serve explanatory or justificatory purposes, imaginaries are more futuristic, projecting visions of what is good, desirable, and worth attaining for a political community. In that sense, imaginaries work as repositories: they provide (symbolic) resources for building and sustaining specific visions and narratives (Felt \& Wynne, 2007, p. 73). Second, sociotechnical imaginaries are not the same as policy agendas: they are less issue-specific, less goal-directed and less instrumental. They refer to the reservoir of norms and discourses, metaphors and cultural meanings out of which actors may build their policy preferences. Third, they are not the same as media packages. There, social reality depends on the repeated use of words and images in public communication. Sociotechnical imaginaries are instead associated with active exercises of state power, such as the selection of development priorities, the allocation of funds, the investment in material infrastructures, and the acceptance or suppression of political dissent.

As a particular kind of sociotechnical imaginary, energy imaginaries centre on the question of how to power modern social life and how to distribute ownership for the costs and benefits of envisaged changes to the shared energy system (Jasanoff \& Kim, 2013, p. 190). Energy systems are closely intertwined with the way that labour is organized, industries are 
clustered, cities grow, leisure time is spend and political affairs are conducted in a particular region (see for example Hughes, 1983; and Nye, 1998). Energy transitions therefore require a major reworking of societal order too (Gjefsen, 2013; Laird, 2013; Miller, Iles, \& Jones, 2013). Identifying energy imaginaries helps to understand why some pathways towards energy reform are favoured over others in a particular setting. ${ }^{28}$ Germany has for example invested in 'risk-free' solar energy, whilst the United States embraced biotech and agriculture (Jasanoff \& Kim, 2012). South-Korea seeks to develop itself through nuclear energy (Jasanoff \& Kim, 2009), whilst Austria traditionally prides itself for being a nonnuclear nation (Felt, 2013). In this chapter, I will argue that such a characterization is problematic for the Netherlands. By imagining itself as a networked nation (an 'open' transit place for international flows of fossil fuels, electricity, goods, people, money and greenhouse gases), realizing energy reform in the Netherlands entails a paradox: formulating attractive long-term visions is crucial for bridging competing interests, but it is at the same time acknowledged that no Dutch party can or should provide a blueprint of the nation's energy future. Put differently: societal parties voluntarily subscribe to collective visions (involving specific energy technologies like CCS), whilst acknowledging that the realization of these visions is heavily curtailed by economic considerations of commercial actors operating in a broader, international energy market.

\subsection{RESEARCH DESIGN}

How to study sociotechnical imaginaries? Jasanoff \& Kim (2009) argue that a longitudinal, interpretative study of national policies and regulations for science-based technologies provides a good starting point. After all, such policies have to balance distinctive national visions of desirable futures against fears of either not realizing those futures or causing unintended harm in the pursuit of technological advances: "S\&T policies thus provide unique sites for exploring the role of political culture and practices in stabilizing particular imaginaries, as well as the resources that must be mobilized to represent technological trajectories as being in the 'national interest'" (Ibid., p. 120-1). A nation's political culture, marked by patterns of public reason, evidence production and knowledge uptake, thus plays an im-

\footnotetext{
${ }^{28}$ Jasanoff \& Kim (2013) claim that different sociotechnical imaginaries are associated with different policy outcome: the US focuses on agri/biotech, Germany on wind and solar, South-Korea on nuclear energy. According to Levidow \& Papaioannou (2013) though, they fail to explain why these pathways were eventually adopted. I do not entirely agree with this criticism: the value of Jasanoff \& Kim's study is arguably that it helps to understand how a certain technological development occurred by contextualizing it, rather than explaining why it occurred by pointing to some form of causality.
} 
portant role in sociotechnical imaginaries (Jasanoff \& Kim, 2009, p. 140; Levidow \& Papaioannou, 2013, p. 38). As collectively imagined forms of social life and social order, these imaginaries are reflected in the design and fulfilment of nation-specific scientific and/or technological projects.

This chapter is based on an analysis of Dutch policy (advisory) documents on energy reform and climate action in general and on CCS specifically from roughly the 1980s onwards. Such documents were supplemented with insights gained during semi-structured interviews with parties working on CCS development in the Netherlands (see Appendix A). Drawing on Jasanoff \& Kim (2009 \& 2013), this material was analyzed to identify the following characteristic elements of the Dutch energy imaginary:

- The risks and benefits of (timely and untimely) energy reform that have risen to political salience in the Netherlands. Particular attention will be paid to the changing views on the climate problem, future fossil fuel scarcity and economic competitiveness, as these fuelled an interest in CCS.

- The dominant knowledge practices by which the Dutch energy future and the associated challenges are explored, and the ways by which this knowledge is put to use for political decision-making. Such practices are meant to anticipate technological developments, but also to ensure (through participation and deliberation) public acceptance for such pathways.

- The envisaged responsibilities of relevant social groups (e.g. the national government, the industry and electricity sector, scientists and environmental NGOs) in realizing energy reform. It will be important here to also discuss the institutionalization of 'transition management' in Dutch policy-making by the turn of the millennium, as this marked a shift in the imagined spatial and temporal horizon for responsible climate action in the Netherlands.

- Avenues and means for realizing closure on the Dutch energy future. These include voluntary agreements, future visions (meant to energize and mobilize societal parties around specific projects) and market incentives. This will also be the place to reflect upon the tensions involved in the implementation of CCS.

The elements above will serve to structure my narrative in the upcoming chapter. I will first set the stage by highlighting some characteristics of the nation's existing energy system. 


\subsection{THE NETHERLANDS - A TRANSIT PLACE FOR FOSSIL FLOWS}

Natural gas has traditionally played an important role in the Netherlands. In 1959, the Dutch Fossil Oil Company (NAM) discovered a huge gas field near Slochteren. In 1963, Gasunie started with the construction of a nation-wide distribution network for natural gas. Five years later, almost all households in the Netherlands were connected to this grid and coal mines in the Southern part of the country were closed. In just a few years' time, the Dutch energy system transformed, through deliberate interventions, from being primarily coal-based to having oil and natural gas as the primary energy carriers (Rotmans, Kemp, van Asselt, Geels, \& Molendijk, 2000, pp. 51-59). The Netherlands is now the biggest producer of natural gas in the EU, with extraction rates peaking to 85 billion $\mathrm{m}^{3}$ in 2010 . It is estimated that the Dutch underground holds another 1.100 billion $\mathrm{m}^{3}$ of recoverable natural gas. ${ }^{29}$

Views on how to utilize this domestic energy source responsibly have changed over time. In the 1960s, the Dutch government still felt that all gas should be sold as soon as possible, as it was expected that nuclear energy would become a cheaper and virtually inexhaustible resource for electricity production. This outlook changed due to public opposition and safety concerns, which were only fuelled by nuclear accidents in Three Mile Island (1979) and Chernobyl (1986). In turn, the Dutch energy policy focused on securing the long-term flow of domestic natural gas. Exploration of smaller gas fields was encouraged and a trans-boundary infrastructure was put in place to import cheaper natural gas from Russia and to export to the United Kingdom. In turn, revenues from natural gas flows increased significantly. They make up an important share of the total state income, amounting to nearly $€ 12$ billion in $2011 .^{30}$

\footnotetext{
${ }^{29}$ Source: Energie Beheer Nederland.

${ }^{30}$ For comparison: taxation of fossil-based electricity production resulted in $€ 4.2$ billion state income and $€ 1.5$ billion was available in subsidies to support renewable energy usage in 2011. See: PBL (2012). Nederland verbeeld: een andere blik op vraagstukken rond de leefomgeving. The Hague: Planbureau voor de Leefomgeving, p.23. In 2014, seismic activity in Northern-Netherlands triggered a debate on risks and safety related to extraction of natural gas. See the critical report by the Onderzoeksraad voor de Veiligheid, following an earlier warning of Staatstoezicht op de Mijnen that more severe earthquakes were to be expected. (Source: ORV (2015). 'Aardbevingsrisico's in Groningen', Onderzoeksraad voor de Veiligheid, February 2015). This report triggered debate on whether or not gas extractions should be lowered and on the effects that this would have for the Dutch energy economy. These contemporary debates largely fall outside the scope of the present chapter, which only focuses on the rise of Schoon Fossiel on the Dutch policy agenda between roughly the 1980s and 2015 (when the main CCS demonstration project in Rotterdam was supposed to start).
} 
Following the second oil crisis of 1978, the Dutch government has also tried to increase the share of renewable energy flows. ${ }^{31}$ Although considerable advancements were made from mid-1990s onwards, renewable sources play only a marginal role in the Dutch energy system. Electricity production for example continues to be based primarily on natural gas and (imported) coals (see Figure 4 below).

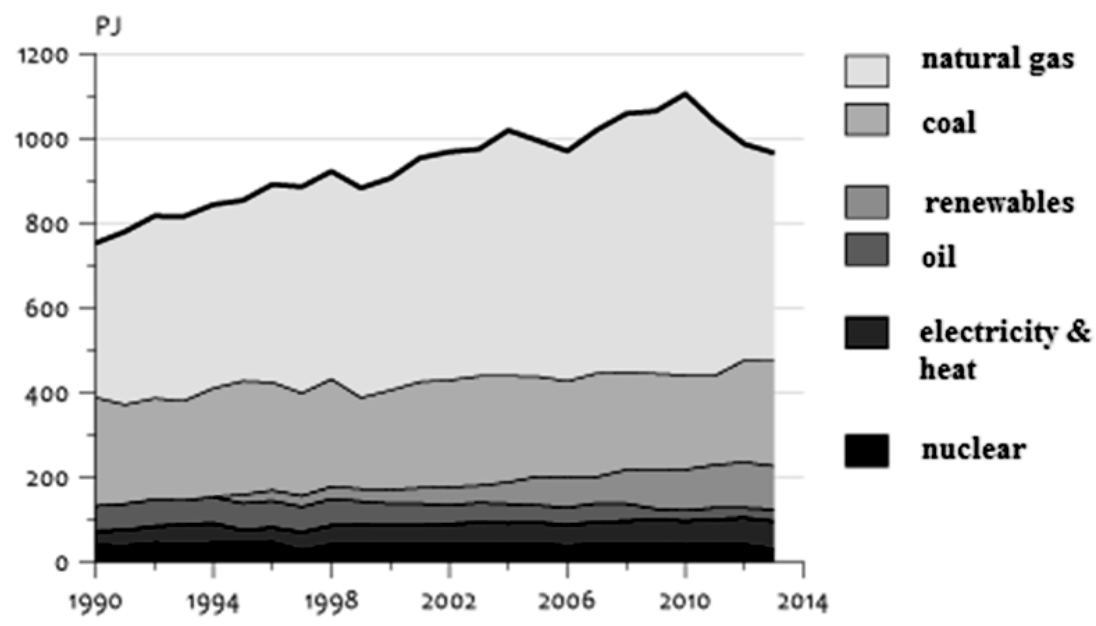

Figure 4: Share of energy carriers for Dutch electricity production (1990-2013).

Source: Centraal Bureau voor de Statistiek, Compendium voor de Leefomgeving, 2014.

In 2012, the total Dutch energy consumption amounted to 3.000 PJ. Roughly 3\% came from renewable sources. Over 10,000 PJ was imported, primarily in the form of crude oil and coals. Export of natural gas, coal and oil products amounted to over $8.700 \mathrm{PJ} .^{32}$ For some, such figures suggest that the Netherlands is best described as a transit place for fossil energy flows (e.g. Lysen, 2011). Or, as the International Energy Agency writes on its website:

"A prominent producer of natural gas in Europe, the Netherlands also serves as a hub for energy trade and transit - a role that could expand in the future." 33

The causality involved is hard to pinpoint. Is this vision of an international 'energy hub' the result of the Dutch geographic location and geological conditions, or are the Dutch socio-

\footnotetext{
${ }^{31}$ See Verbong et al. (2001) for a historical overview of the development of renewable energy technologies in the Netherlands.

32 Source: Compendium voor de Leefomgeving.

${ }^{33}$ Source: http://www.iea.org/countries/membercountries/netherlands/. Archived under: http://www.webcitation.org/6OKsKjAs9. WebCite (r) is an on-demand archiving system, providing stable copies of archived web pages. I will use this system when referring to online sources.
} 
technical systems for handling and transporting fossil flows the result of the nation's ambition to become an international energy hub? In this Chapter, I will trace the 'coproduction' of energy systems and socio-political ambitions in the Netherlands over a period of several decades. To structure my narrative, I will sketch the characteristics of an emerging energy imaginary, according to which the Netherlands is (or should become) a networked nation, open to international flows of fossil energy carriers and $\mathrm{CO}_{2}$.

\subsection{RISKS AND BENEFITS AS INCENTIVES FOR CHANGE}

Jasanoff \& Kim (2009) argue that energy imaginaries are characterized by a particular framing of the risks of technical innovations developing either too slow or too rapidly. In the Netherlands, two main incentives for energy reform can be identified: (i) concerns over global warming and (ii) vulnerability of the Dutch energy economy. The precise interpretation of these changed over time, as I will discuss next. Importantly, both environmental and economic incentives for energy reform were understood against the background of (and helped sustain) an imaginary of the Netherlands being a 'networked nation.'

\subsubsection{Global warming and national targets}

Environmental thinking in the 1970s and 1980s was heavily influenced by reports from the Club of Rome and the Brundlandt Commission. Both underlined that drastic changes were needed to avoid that unchecked industrialization would result in irreversible environmental degradation. In the Netherlands, this mood was forcefully captured by the Rijksinstitunt voor Volksgezondheid en Milieu (RIVM). Its report 'Zorgen voor morgen' (touted the nation's "first scientifically grounded environmental exploration") warned that increased atmospheric $\mathrm{CO}_{2}$ concentrations could lead to an average temperature rise of $8^{\circ} \mathrm{C}$ and a sea level rise of up to 70 centimetres by $2100 .^{34}$ In response, the Dutch government published its first National Environmental Policy Plan (NMP1), starting with a gloomy diagnosis: "The environment is in a disastrous state." ${ }^{35}$ Global warming and associated sea-level rise

\footnotetext{
${ }^{34}$ RIVM. (1988). Zorgen voor Morgen - Nationale Milieuverkenning 1 (1985-2010). Rijksinstituut voor Volksgezondheid en Milieuhygiene, p. xv.

${ }^{35}$ NMP1. (1989). Nationaal Milieubeleidsplan. Ministerie van Volkshuisvesting, Ruimtelijke Ordening en Milieubeheer, p.1.
} 
were portrayed as "great risks" threatening the Netherlands. ${ }^{36}$ Building upon a century-old tradition of forward-looking public planning (Hanf \& van de Gronden, 1998), NMP1 aimed to reverse environmental degradation within just one or two generations. Under the broad norm of 'sustainable development,' several other norms were institutionalized too: the Dutch government strived for (i) equitable, (ii) cost-effective and (iii) precautionary implementation of the polluter-pays principle. In practice, this meant that mainly 'no regret' measures were pursued. This refers to measures (e.g. energy saving) which have additional benefits besides uncertain climate effects (Pettenger, 2007).

NMP1 was one of the first official documents to specifically address climate change as a serious environmental problem. It included an ambitious target of stabilizing domestic GHG emissions at 1989/1990 levels in 2000. ${ }^{37}$ After publication of NMP1, the Netherlands tried to position itself as international leader on climate action. Together with Germany and France, the Dutch government successfully raised climate change as an EC policy issue (Cass, 2006, p. 44). Members of the European Community were urged to install an international tax on carbon-intensive fuels and to formulate GHG objectives. When European nations committed to stabilize their $\mathrm{CO}_{2}$ emissions in 2000 by signing the 1992 UNFCCC Rio Declaration, the Dutch government went a step further. It aimed to stabilize domestic GHG emissions already in 1995, after which a reduction of 3 to $5 \%$ should be achieved by 2000 compared to $1990 .^{38}$ After ratifying the Kyoto Protocol in 1994, the Dutch government sought to reduce emissions with 6\% by 2008-2012 compared to 1990 . In 2001, it argued that a reduction of 40 to $60 \%$ should be the "normative objective for Western Europe for the year 2030" (NMP4, 2001). ${ }^{39}$ By 2007, the national goal was to reduce GHG emissions with $30 \%$ by 2020 compared to $1990 .{ }^{40}$

The role of such quantitative targets in imagining energy reform can hardly be overstated. By providing a time horizon (typically one or two decades), a spatial boundary (the Netherlands) and a unit of analysis to assess the effectiveness of climate policies $\left(\mathrm{CO}_{2}\right.$ emis-

\footnotetext{
${ }^{36}$ Ibid, p.9. They were arguably seen as uncertain risks. Assessments of future climate change entailed numerous scientific uncertainties, so the Dutch government opted for a precautionary approach. See for example EZ. (1993). Vervolgnota Energiebesparing. Ministerie van Economische Zaken, p. 37. The plea for precautionary climate action came with a call for innovating the associated knowledge practices too (e.g. Rotmans \& van Asselt, 1996; van Asselt \& Rotmans, 1996). This will be further explored in Section 2.5.

${ }^{37}$ NMP1. (1989). Nationaal Milieubeleidsplan. Ministerie van Volkshuisvesting, Ruimtelijke Ordening en Milieubeheer, p.66. Schoon Fossiel was not yet mentioned at the time: "As there are currently no affordable possibilities for fighting $\mathrm{CO}_{2}$ (in Dutch: 'bestrijdingsmogelijkheden'), emissions reductions can only be achieved through energy saving, choice of fuel usage and using sustainable energy sources" (Ibid., p.213.).

${ }^{38}$ NMP2. (1994). Milieu als maatstaf. Ministerie van Volkshuisvesting, Ruimtelijke Ordening en Milieubeheer.

${ }^{39}$ NMP4. (2001). Een wereld en een wil - Werken aan duurzaamheid. Ministerie van Volkshuisvesting, Ruimtelijke Ordening en Milieubeheer.

${ }^{40}$ VROM. (2007). Nieuwe energie voor het klimaat. Werkprogramma Schoon en Zuinig.
} 
sions), the targets have greatly structured the ideas on when, where and how energy reform should be achieved. ${ }^{41}$ The Dutch government has always portrayed anthropogenic climate change as a global risk waiting for an international solution. Setting national (or regional) reduction targets helped to delineate a time and space for responsible climate action and to prevent that continued debate on the uncertainties involved in anthropogenic climate change would stifle innovation. ${ }^{42}$

Although seemingly clear-cut, the GHG emission reduction targets entailed numerous ambiguities. The spatial boundary for realizing the objectives was for example deliberately blurred. By ratifying the Kyoto Protocol, the Dutch government agreed to reduce its GHG emissions by $6 \%$ in 2008-2012. But during post-Kyoto negotiations, the precise way in which this target should be realized became fiercely contested: was it a national responsibility or should cost-effectiveness be the guiding principle, allowing for greater implementation of flexible instruments like Joint Implementation, Clean Development Mechanisms and international GHG emission trading schemes? In this 'normative battle' (Cass, 2006), the Dutch government defended the latter position. It vigorously opposed binding domestic targets, not least because energy saving and natural gas (less carbon-intensive than oil and coal) already played an important role in the Dutch power sector, making it relatively expensive for the nation to realize further emission reductions. ${ }^{43}$ By the turn of the millennium, it was decided that only $50 \%$ of the 'Dutch' GHG emission reduction should be realized within the Netherlands. The rest could be done via flexible instruments.

\footnotetext{
${ }^{41}$ Compare: "So long as scientists and policy makers frame climate policy in terms of stabilizing concentrations of atmospheric carbon dioxide, then we should expect geo-engineering [including carbon sequestration] to be a key part of the international climate policy debate" (Pielke Jr., 2010, p. 142). See Boehmer-Christiansen (2003) for a critique on this 'technocratic' approach towards responsible climate action.

${ }^{42}$ Sheila Jasanoff (2010a) has pointed out that there is a potential mismatch between (i) the impersonal, apolitical and universal image of global warming advanced by scientific assessments and (ii) the subjective, normative and situated images which tend to guide societal responses to climate change. Put differently: when climate change is portrayed as a global phenomenon (based on impersonal observations), it may become detached from the embedded experiences which inspire us to do things differently. National and regional targets for GHG emission reductions can be seen as an attempt to bridge this gap.

${ }^{43}$ The Dutch emphasis on international cooperation for trans-boundary environmental problems was based, at a minimum, on a well-understood self-interest (Hanf \& van de Gronden, 1998, p. 155). De Jong et al. (2005, p. 138) note for example that using 1990 as a reference point for climate objectives was strategically pushed for by the Dutch government, as it meant that the emissions of the newly-constructed coal-fired power plants at Amer and Hemweg- 8 would be included in the baseline. The Dutch (internationally-connected!) natural gas infrastructure was important too. In the 1990s, estimations of the domestic gas reserve had greatly increased due to newly discovered reservoirs and updated capacity calculations. With natural gas (the least carbon intensive of all fossil energy carriers) abundantly available within its borders, the Dutch government felt that a competitive advantage might be gained if stringent international targets for GHG emission reductions were agreed.
} 
In 2005, the spatial boundary for climate action was further blurred with introduction of the EU's emission trading scheme (EU-ETS). This scheme covers around $2000 \mathrm{Mt}$ of $\mathrm{CO}_{2}$ a year, representing roughly half of Europe's total emissions. As an artificial market, the EU-ETS can be seen as a 'techno-political experiment' (Callon, 2009; MacKenzie, 2010). It required an elaborate bureaucratic infrastructure for tracking carbon emissions in EU member states. The resultant archive has informed political (and highly contested) decision-making on the distribution of allowances, as this is based on an assessment of further reductions that are considered feasible for affected sectors. After its introduction, the EU-ETS has become the primary means by which EU member states meet their obligations under the Kyoto Protocol. In 2008, trading totalled nearly \$92 billion. In the context of the present chapter, it is important to note that the EU-ETS made 'national' climate targets less effective in providing an incentive for energy reform and stimulating technological development.

The Dutch government lobbied extensively for this international cap-and-trade system, as other instruments were seen as endangering the competitiveness of its domestic export industries (Wurzel, Zito, \& Jordan, 2013, p. 164). Already in 1998, the Dutch government noted:

"For an open economy like ours, it is undesirable to weaken its competitive position by putting costly $\mathrm{CO}_{2}$ policies in place. Especially energy-intensive exporting companies are incapable of incorporating the costs of $\mathrm{CO}_{2}$ policies in their product prices. (...) Therefore, the introduction of a system of tradable emission reductions could offer important benefits for the nation as a whole." 44

The above illustrates that Dutch climate policies were informed by a particular understanding of the nation as an open (or: 'networked') energy economy, as will be further explored next.

\subsubsection{Vulnerability of the Dutch energy economy}

Like many European countries, the Netherlands became keenly aware of its dependence on fossil flows during the oil crises of the 1970s. These crises underlined that political developments abroad could have a direct impact on the domestic energy supply. Oil from the Middle East, natural gas from Eastern Europe, liquid gas from Algeria, coal from Northern

\footnotetext{
${ }^{44}$ NMP3. (1998). Nationaal Milieubeleidsplan 3. Ministerie van Volkshuisvesting, Ruimtelijke Ordening en Milieubeheer, p. 220, italics added.
} 
America: all were streams that could potentially 'dry-up. ${ }^{35}$ To deal with this risk, the Netherlands sought political solutions. It for example became a founding member of the International Energy Agency (IEA), which was charged to design an international system of oil stocks that could be deployed in case of future embargos. ${ }^{46}$ Geopolitical developments were not the only reason for concern though. Throughout the 1970s, the dominant expectation was that fossil reserves would be depleted within just a few decades. ${ }^{47}$ When the Dutch government published its first Energienota in 1974, fossil fuel scarcity was explicitly mentioned as a source of economic vulnerability. ${ }^{48}$ Prescribed medicine was to increase energy saving and to diversify the domestic fuel mix. ${ }^{49}$

From the 1980s onwards, liberalization of the European energy market became a dominant policy in Western Europe (Cass, 2006, p. 199). This trend further increased the openness and interconnectedness of the Dutch energy economy and greatly affected Dutch thinking about effective climate policies. Still expecting fossil fuel scarcity in the nearfuture, it made sense to lower and discourage their usage. ${ }^{50}$ But the Ministry of Economic Affairs (EZ) underlined that such a policy would have to strike a balance:

"It should be avoided that Dutch exporting companies have to stop their activities due to the Dutch climate policy, if this means that products are then produced elsewhere in a less efficient manner. From a climate perspective, this would entail a net loss." 51

\footnotetext{
${ }^{45}$ This indicates that not only drying-up but also the abundance of fossil streams has historically been an incentive for energy reform. In the 1960s, the availability of cheap coal from the US for example made closure of coal mines in Southern Netherlands possible. More recently, the rise of shale gas extraction in the US has again led to an increased import of 'cheap' American coal, causing shifts in the merit order of electricity production.

${ }^{46}$ After its inception in the 1970s, the IEA has developed into one of the world's most influential institutions for multilateral energy cooperation. Its focus has shifted over time. Due to integration of the oil market, changes in the global energy mix (i.e. growing demand for natural gas) and the rise of climate change on the political agenda, the IEA was gradually transformed from an emergency response organization to a proactive policy adviser guiding governments on issues related to energy security and global warming (van de Graaf \& Lesage, 2009). Activities of the IEA underline the global interconnectedness of energy systems, which affects the 'open' Dutch economy in particular.

${ }^{47}$ Verbong \& van Selm (2001, p. 60) note that the Energienota-I of 1974 put 'uncertainty' centre stage in Dutch energy policies: "The certainties of the past, a constant growth, made possible by a reliable and cheap energy supply, had disappeared. Instead, there emerged a nagging sense of uncertainty: what will the future energy demand look like and in what way can this demand be accommodated?"

${ }^{48}$ EZ. (1974). Energienota-I. The Hague: Ministry of Economic Affairs.

${ }^{49}$ See also: EZ. (1979). Energienota-II. The Hague: Ministry of Economic Affairs.

${ }^{50}$ See NMP+. (1990). Nationaal Milieubeleidsplan-plus. Den Haag: Ministerie van Volkshuisvesting, Ruimtelijke Ordening en Milieubeheer. And: NME. (1997). Nota Milieu en Economie: Op weg naar een duurzame economie. Den Haag: VROM, EZ, LNV, V\&W.

${ }^{51}$ EZ. (1996). Energienota-III. The Hague: Ministry of Economic Affairs, p. 75.
} 
So, the (imagined and sought-after) openness of its energy economy has traditionally made the Dutch government reluctant to take climate actions that will place its domestic industries at a competitive disadvantage (Hanf \& van de Gronden, 1998).

Importantly, views on fossil fuel scarcity started to change towards the turn of the millennium. It was expected that coal, oil and gas reserves would be big enough for "centuries of intensive energy usage." ${ }^{2}$ Given this novel outlook, a shift in problem definition occurred. As civil servants from the Ministry of VROM (working to advance underground $\mathrm{CO}_{2}$ storage as members of the fledgling international CCS community) put it:

"We have learned that fossil fuel supplies will be adequate to supply world energy needs for a long time to come. It is not energy, but rather the atmosphere's ability to absorb carbon which is the real 'scarcity' problem." 53

The Dutch government started to adopt a similar stance. The climate strategy was no longer to limit or discourage fossil flows, nor to realize a Dutch energy system based on renewable sources alone. Instead, the Netherlands had to become 'climate-neutral.' This framing was adopted in the first Energierapport of 1999, in which the Dutch government sketched its long-term energy strategy. ${ }^{54}$ Citing studies by the IPCC and IEA, it was expected that oil, coal and gas would continue to dominate the global economy for decades to come. In turn, it was suggested that the Netherlands should aim to utilize these fossil flows as cleanly as possible. This could be done via, amongst others, CCS. ${ }^{55}$

In sum, timely development of CCS was meant to reduce the vulnerability of the nation's open energy economy whilst expecting (and actively pursuing) ever more stringent climate action on an international level. ${ }^{56}$ What knowledge was drawn upon to imagine the role of CCS in the Dutch energy future?

\footnotetext{
${ }^{52}$ NMP4. (2001). Een wereld en een wil - Werken aan duurzaamheid. Ministerie van Volkshuisvesting, Ruimtelijke Ordening en Milieubeheer, p. 133. See also: "Until 2050, the worldwide demand for primary energy carriers is expected to double, perhaps even quadruple. There will be an immense pressure to exploit all available sources, both of fossil, renewable and nuclear origin. Paradoxically, it turns out that renewable sources are, in practice, often more 'scarce' than fossil ones. We have enough coal for centuries to come, and a very large gas reserve seems to be on the horizon." Source: Stuij, B. \& H. Schreurs (2002). Zwarte schoonheid? Over de fossiele bijdrage aan een verduurzamende energiehuishouding. Appendix of AER (2002). 'Post-Kyoto Energiebeleid: Advies aan de Minister van Economische Zaken', p. 50-6.

${ }^{53}$ Lenstra, W., \& Van Engelenburg, B. (2000). 'Climate policy, $\mathrm{CO}_{2}$ storage and public perception'. In D. Williams, R. A. Durie, P. McMullan, C. A. J. Paulson, \& A. Y. Smith (Eds.), Proceedings of the $5^{\text {th }}$ International Conference on Greenhouse Gas Control Technologies. Cairns (Australia), p.32.

${ }^{54}$ EZ. (1999). Energierapport-I. The Hague: Ministry of Economic Affairs.

${ }^{55}$ The VROM-Raad was one of the first policy-advisory bodies to call for large-scale development of Schoon Fossiel in the Netherlands, following feasibility studies by researchers at Utrecht University (Blok et al., 1989; Hendriks, 1994).

${ }^{56}$ NL. (1998). Uitvoeringsnota Klimaatbeleid. Tweede Kamer: Nota 26603 (nr.2), p. 37.
} 


\subsection{KNOWLEDGE ON THE DUTCH ENERGY FUTURE}

In the Netherlands, several institutes provide policy-advice on energy reform and CCS in particular. The Energie Centrum Nederland (ECN) is the nation's largest energy research institute. Founded in 1955, it initially specialized in nuclear energy only. After the oil crises of the 1970s, this focus was broadened to include e.g. solar, wind and coal gasification technologies too. Since 2001, ECN's entire program is focused on (i) energy efficiency, (ii) renewable energy and (iii) Schoon Fossiel. Other parties doing research on CCS are the Netherlands Organization for Applied Scientific Research (TNO), with its cluster of geological expertise, and consultancy firms like Ecofys or CE-Delft. In 2004, Dutch expertise on Schoon Fossiel was clustered in a national research consortium: $\mathrm{CO}_{2}$ Afvang, Transport en Opslag (CATO). Led by researchers at Utrecht University, this network started as a bottomup initiative (Vergragt, 2009a). The objective was initially "to find out whether the promises of CCS will hold for the Netherlands." ${ }^{57}$ Receiving over $€ 25$ million in subsidies, Phase 1 of CATO (2004 - 2008) focused on i.e. improving capture efficiency, monitoring postinjection $\mathrm{CO}_{2}$ behaviour and risk perceptions. Participants included representatives of the energy sector, universities and research institutes and several environmental organizations. ${ }^{58}$ Looking at CCS reports produced by such institutes, two knowledge practices stand out as crucial for imagining the Dutch energy future: (i) scenarios on potential GHG emission reductions and (ii) back-casting on the basis of long-term objectives. Such practices were not static. They have evolved over time, due to changed framing of the climate problem and changed views on how to realize socio-technical change in an open energy economy.

\subsubsection{Looking ahead, ranking pathways}

After the Dutch government adopted quantitative emission targets, scenario studies were used to assess how reductions could (and how much should) be achieved in the future. In 1992, ECN for example published a National Energy Outlook, sketching three scenarios with different assumptions about industrial change, fuel prices, technological development and the level of European cooperation in the period 1990-2015..$^{59}$ Balanced Growth was the

\footnotetext{
${ }^{57}$ Source: CATO. (2009). Catching carbon to clear the skies: Experiences and highlights of the Dutch R\&D programme on CCS. Utrecht: Dutch CATO Program, p.5.

${ }^{58}$ Phase 2 of CATO, running from 2009 to 2013, focused more on applied research and support for early CCS projects. In turn, more industrial groups were enrolled, while some environmental NGOs (like Greenpeace) decided to drop-out. I will return to the role of CATO in more detail in Chapter 3.

${ }^{59}$ ECN. (1992). Nationale energie verkenningen (1990 - 2015). Energie Centrum Nederland.
} 
most 'optimistic' scenario, characterized by high economic growth, fast technological developments and a strong emphasis on free-market principles. It was calculated that GHG reduction targets could only be achieved via a combination of coal gasification plants with CCS and nuclear power plants. It was noted that this would require a "fundamental change in Dutch decision making on energy." ${ }^{60} \mathrm{ECN}$ claimed to "explore the Dutch energy future," but doing so forced the researchers to make assumptions about the future sociopolitical order too. After all, a limited set of reduction options was fed into the computer model while others were neglected (like applying CCS to existing power plants), and numerous assumptions had to be made about the conditions under which CCS would have to operate in the future (e.g. on the acceptability of onshore or offshore $\mathrm{CO}_{2}$ storage locations). Scenario studies thus not merely explored particular pathways for energy reform but also helped to construct these pathways. ${ }^{61}$

To increase their policy-relevance, scenario studies are typically combined with a costeffectiveness analysis. ECN and RIVM for example ranked emission reduction options on this basis in their 1998 study on how to meet the Dutch Kyoto target. ${ }^{62}$ CCS had an estimated reduction potential of 14 Mton $\mathrm{CO}_{2}$ by 2010 if it was applied to two new coalgasification plants and three existing power plants. This was considered feasible only in case of "very expeditious implementation." 63 Other options were energy saving, solar panels, wind energy, heat pumps, fuel-switching and reduction of other GHGs, like methane. The share of each option in possible reduction packages was plotted as a function of costeffectiveness and the share of reductions that had to be achieved domestically instead of abroad through flexible instruments (see Figure 5 below).

\footnotetext{
${ }^{60}$ Ibid., p. 2.

${ }^{61}$ Scholars studying the role of discourse and argumentation in policy formation have made similar points (F. Fischer \& Forester, 1993). Scenario studies have informed thinking about EU-wide CCS infrastructures (Kjärstad \& Johnsson, 2009; Neele, Hendriks, \& Brandsma, 2009; 2009) and have helped to imagine the role of CCS in the global energy system too (IPCC, 2005). Social scientists Bryngelsson \& Hansson (2009) provided a critical analysis of the (often overlooked) role of uncertainty in scenario studies for CCS in particular. They argue that such studies serve to 'colonize the future', in the sense that they also restrict the ways by which societies imagine their energy future. Put differently, a restricted framing of scenario studies may 'close-down' the imagined pathways for realizing energy reform (Stirling, 2004; Leach, Scoones, \& Stirling, 2010). Parties working on Schoon Fossiel in the Netherlands have responded to such criticism by trying to open-up the knowledge practice of scenario studies to broader societal/stakeholder concerns. For a good example of such a participatory approach, see Ramirez, Hoogwijk, Hendriks \& Faaij (2008). See also the back-casting exercises discussed below.

${ }^{62}$ ECN, \& RIVM. (1998). Optiedocument voor emissiereductie van broeikasgassen - Inventarisatie in het kader van de Uitvoeringsnota Klimaatbeleid. Energieonderzoek Centrum Nederland \& Rijksinstituut voor Volksgezondheid en Milieu.

${ }^{63}$ Ibid., p. 136.
} 


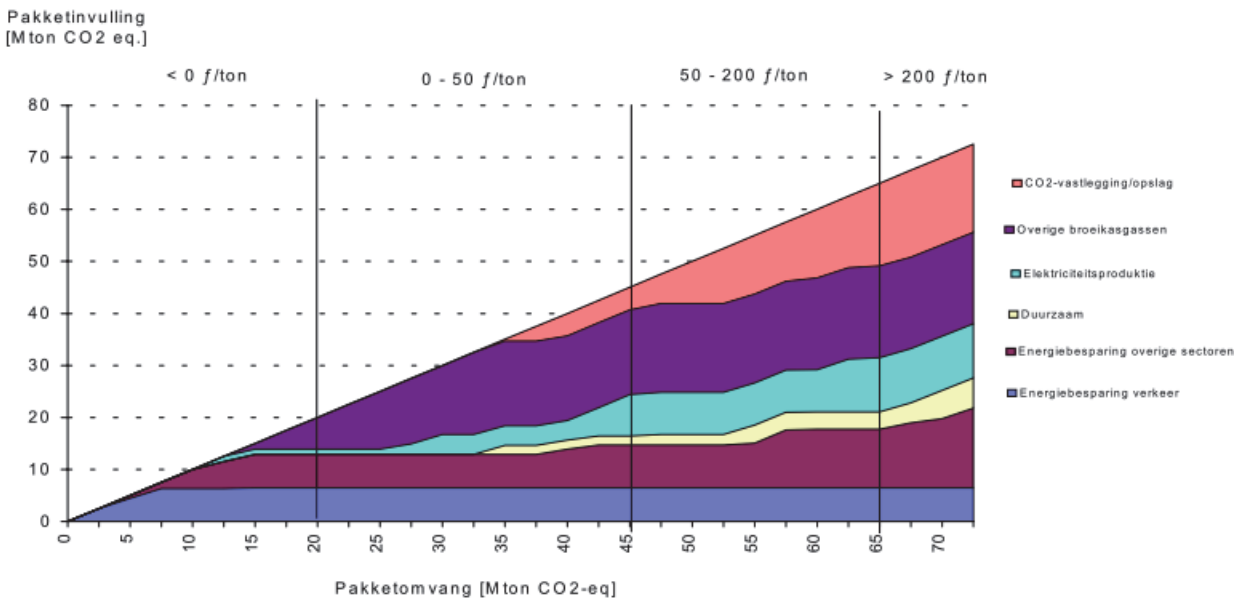

Figure 5: Packages for domestic reduction ranked by cost-effectiveness, with CCS being the top chunk.

Source: ECN, \& RIVM. (1998). Optiedocument voor emissiereductie van broeikasgassen - Inventarisatie in het kader van de Uitvoeringsnota Klimaatbeleid. Energieonderzoek Centrum Nederland \& Rijksinstituut voor Volksgezondheid en Milieu, p. 162

The resultant plot was meant to provide input for political decision-making. It suggested for example that ' $\mathrm{CO}_{2}$ sequestration' ${ }^{64}$ had the second largest reduction potential, but came at a cost. This also meant that the future share (and 'necessity') of CCS depended mostly, if not entirely, on the political choice regarding how much GHG reduction should be achieved domestically and how much could be realized elsewhere via flexible instruments. If less than 35 Mton (out of an estimated total of 50 Mton) reduction needed to be achieved domestically by 2010 , injecting $\mathrm{CO}_{2}$ under Dutch territory would not be needed at all. ${ }^{65}$

Eight years later, ECN and the Milieu en Natuur Planbureau ${ }^{66}$ published an updated Option Document, sketching the reduction potential, costs and estimated societal support for more than 150 pathways to reduce GHG emissions by 2010/2020. ${ }^{67}$ The Global Economy scenario was used as a reference point, expecting high growth in both population and

\footnotetext{
${ }^{64}$ This study actually referred to both $\mathrm{CO}_{2}$ sequestration through forestry and underground $\mathrm{CO}_{2}$ storage.

${ }^{65}$ ECN, \& RIVM. (1998). Optiedocument voor emissiereductie van broeikasgassen - Inventarisatie in het kader van de Uitvoeringsnota Klimaatbeleid. Energieonderzoek Centrum Nederland \& Rijksinstituut voor Volksgezondheid en Milieu, p. 166.

${ }^{66}$ In 2008, the MNP merged with the Ruimtelijk Planbureau to become the Planbureau voor de Leefomgeving $(\mathrm{PBL})$, charged with conducting strategic policy analysis. See also: Hajer, M. (2011). De energieke samenleving: Op zoek naar een sturingsfilosofie voor een schone economie, The Hague: Planbureau voor de Leefomgeving. ${ }^{67}$ ECN, \& MNP. (2006). Optiedocument Energie en Emissie (2010 - 2020). Energieonderzoek Centrum Nederland \& Milieu en Natuurplanbureau. This report was explicitly referred to by the Dutch government in backingup its environmental policies and has been described as particularly influential for the development of Schoon Fossiel in the Netherlands (van Alphen, 2011, p. 85).
} 
economic activity and a significant rise of $\mathrm{CO}_{2}$ production. The analysis assumed that application of CCS would result in no more than $16 \mathrm{Mt} /$ year in 2020 . In turn, costoptimal reduction packages were calculated. Large-scale utilization of CCS and nuclear energy was expected to be necessary worldwide for stabilizing atmospheric $\mathrm{CO}_{2}$ concentrations at $450 \mathrm{ppm}$. It was argued that excluding these options would significantly increase the costs of climate action in the Netherlands, as relying on alternatives only (like renewable and energy saving) would be more costly:

"When nuclear energy is excluded, the annual costs of future climate policy increase with $€ 590$ million; when $\mathrm{CO}_{2}$ storage is excluded, costs rise with $€ 1.8$ billion/year." 68

There is a striking difference between the reports of 1998 and 2006. The former study portrayed CCS as a costly 'backstop' option that should only be deployed in case other domestic reduction options had fallen short. In the latter, not developing CCS was portrayed as a costly option. How to account for this change?

Throughout the 1990s, visions of CCS were directly linked to the assessment of how much additional $\mathrm{CO}_{2}$ emissions should be reduced domestically to realize near-term targets. ${ }^{69}$ As most considered CCS "expensive, requiring a lot of additional energy and involving several uncertainties," it remained part of the Dutch reserve package on climate action. ${ }^{70}$ By the turn of the millennium though, Dutch policy-makers started to adopt a broader framing of the climate problem. In 2006, scenario studies looked at the global objective of limiting the world's temperature increase to $2^{\circ} \mathrm{C}$ and stabilizing $\mathrm{CO}_{2}$ concentrations at $450 \mathrm{ppm}$ (as calculated by the IPCC and embraced by the EU). ${ }^{71}$ In order to reach this long-term target by 2050 or 2100 , anticipatory energy reform was needed within the upcoming decades. ${ }^{72}$ Expecting (i) continued global use of fossil flows and (ii) increased carbon constraints, early investment in CCS was portrayed as a sensible precautionary

\footnotetext{
${ }^{68}$ MNP. (2006). Van klimaatdoel naar emissiereductie - Nieuwe inzichten in de mogelijkheden voor beperking van klimaatverandering. Milieu- en Natuur Planbureau, p. 51.

${ }^{69}$ See for example: NL. (1998). Uitvoeringsnota Klimaatbeleid. Tweede Kamer: Nota 26603 (nr.2).

${ }^{70}$ EZ. (1996). Energienota-III. The Hague: Ministry of Economic Affairs, p.65.

${ }^{71}$ MNP. (2006). Van klimaatdoel naar emissiereductie - Nieuwe inzichten in de mogelijkheden voor beperking van klimaatverandering. Milieu- en Natuur Planbureau.

${ }^{72}$ See also: PBL, \& ECN. (2011). Naar een schone economie in 2050 - Routes verkend (Hoe Nederland klimaatneutraal kan worden). Planbureau voor de Leefomgeving \& Energieonderzoek Centrum Nederland. And: ECN, \& SEO. (2012). Kosten en baten van $\mathrm{CO}_{2}$-emissiereductie maatregelen. Energie Centrum Nederland \& SociaalEconomische Raad.
} 
strategy in the Dutch context. ${ }^{73}$ This broader framing of the climate problem required innovations in the knowledge practice of scenario studies too.

\subsubsection{Reasoning backwards to identify future barriers}

From roughly 2000 onwards, Dutch environmental policy-making has been based on a double time horizon. For meeting the Kyoto targets, it sufficed to look one or two decades ahead. But stabilizing global atmospheric $\mathrm{CO}_{2}$ concentrations was expected to take five or even ten decades. Forecasting technological developments was deemed to fall short here, due to the large uncertainties involved. In turn, the practice of back-casting was introduced. Back-casting can be defined as "a participatory method that explores the innovations necessary to realizing a collectively formulated picture of a sustainable future in the long term" (Kok, Vermeulen, Faaij, \& De Jager, 2002, p. 12). As a formal approach to imagining alternative futures, back-casting has two functions. First, it promises to reduce mistrust between parties through greater involvement of those potentially affected by future energy reform (O'Riordan \& Timmerman, 2001, p. 439). Second, it allows for more precautionary policy-making: rather than trying to forecast potential impacts in a deterministic fashion, government agencies, industry, environmental groups and the public are now invited to develop a collective vision of where society should be and then work backward to determine steps towards that goal (Tickner, 1999, p. 163).

An example of back-casting was the Dutch research project on 'Climate Options fOr the Long term' (COOL). Scenario studies had long promised "salvation through technology, with a touch of economic instruments or regulations added, depending on the scientific discipline of the authors" (Hisschemöller, Van de Kerkhof, Kok, \& Folkert, 2002, p. 217). Social scientists now emphasized that realizing such technocratic visions would require social changes too and decided to organize a "national dialogue" between representatives from government, industry and environmental groups. Two long-term visions were drafted, both allowing for a domestic GHG emission reduction of $80 \%$ by 2050 compared to 1990 (see Faaij, 2002). 'Reasoning backwards' was used to identify institutional and cultural barriers to pathways that might lead to one of the visions sketched. Back-casting exercises could serve other purposes too. Some for example considered it "an important tool to prove

\footnotetext{
${ }^{73}$ VROM, \& AER. (2004). Energietransitie: Klimaat voor nieuwe kansen. VROM-raad \& Algemene Energieraad, p. 38. A similar reasoning is adopted by parties who portray CCS as a 'necessary' climate strategy at the international level too. See e.g. IEA. (2008). $\mathrm{CO}_{2}$ capture and storage: A key carbon abatement option (Energy Technology Analysis). IEA/OECD.
} 
the necessity of CCS as a third pillar of the Dutch climate policy." 74 This function was contested though, as back-casting could also be used to argue the opposite. Greenpeace for example constructed a "normative" scenario to reduce European GHG emissions with $80 \%$ by 2050 . This particular back-casting exercise suggested that such a target could be achieved even without CCS: renewable sources and energy efficiency could make an almost complete phase-out of fossil fuels in Europe possible. ${ }^{75}$

In sum, back-casting provided knowledge on barriers towards alternative energy futures and could be used to explore whether desired, normative futures were 'realistic' (in the sense that they could garner the required societal support). It is important to note here that back-casting is a participatory form of knowledge production. By 2001, it was commonly acknowledged in the Netherlands that a pathway's emission reduction potential could not be assessed by looking at technical feasibility, storage capacity and cost-effectiveness alone. Stakeholder / public acceptance was considered crucial, because pathways would have to be realized by a network of actors. ${ }^{76}$ This envisaged responsibility has developed over time, as the next section will show.

\subsection{CHANGING RESPONSIBILITIES FOR ENERGY REFORM}

In the 1970s and 1980s, Dutch environmental policy still focused on top-down implementation of post-hoc regulations. In its first National Environmental Policy Plan of 1989 though, the Dutch government started to portray itself as a facilitator of change. Its envisaged role was to formulate 'quality objectives' (i.e. in the form of quantitative GHG emissions reduction targets) that would provide "the right conditions for environmentally friendly behaviour, stimulating, guiding and investing." 77 Realizing these objectives was

\footnotetext{
${ }^{74}$ Jip Lenstra (Ministry of VROM), quoted in: IEA-GHG. (2001). Report of a seminar "Putting $\mathrm{CO}_{2}$ sequestration on the policy agenda”, 13-14 March 2001 (PH4/2). IEA Greenhouse Gas R\&D Programme \& CO2NET, italics added.

${ }^{75}$ Greenpeace. (2005). Energy revolution: A sustainable pathway to a clean energy future for Europe (A European energy scenario for $E U-25)$. Greenpeace International. Note that this is one of the few energy scenarios without CCS. Several interviewees questioned therefore its economic feasibility and felt that it represented an 'unrealistic' vision of the energy future.

${ }^{76}$ It is illustrative that expectations on public acceptance greatly affected the expected future share of CCS in the Dutch energy mix. In a study commissioned by the World Nature Fund, Ecofys assumed for example that by 2050 still only 11.5 Mton of $\mathrm{CO}_{2}$ would be stored in depleted gas fields, due to a lack of public acceptance and regulatory uncertainty. Source: Ecofys (2006). A low-carbon vision for the Netherlands in 2050. PECSNL061624. ${ }^{77}$ NMP1. (1989). Nationaal Milieubeleidsplan. Ministerie van Volkshuisvesting, Ruimtelijke Ordening en Milieubeheer, p. 89
} 
considered the responsibility of affected target groups. ${ }^{78}$ After liberalization of the power sector, increased emphasis was placed on cooperation between target groups, governments and other stakeholders. As energy companies had to compete at a (semi-) international market, setting an 'unrealistic' target would harm the nation's international competitiveness. The Dutch government therefore pursued an EU-wide climate approach. In so far as it was successful in this, there were paradoxically also fewer means to realize domestic energy reform. ${ }^{79}$ In this context, the national government started to portray itself as only one player within a broader network:

"The national government cannot shape the environmental policy agenda by itself, let alone execute it. The national government is one of the partners in a network, consisting also of other government bodies, targets groups, societal organisations and citizens." $" 0$

By the turn of the millennium, it had become clear that policies to decouple economic growth and environmental pressure had fallen short. In fact, Dutch GHG emissions had risen with $11 \%$ between 1990 and $1997 .{ }^{81}$ Further liberalization and economic harmonization was expected to fall short for reaching the national targets. In turn, the aim of Dutch policies shifted from decoupling in the short term to realizing a sustainable energy economy in the longer term.

\subsubsection{Transitions as collective journeys}

The metaphor of an 'energy economy' [in Dutch: energiehuishouding] suggests not so much homogeneity of interests, but rather an economic co-dependence of the nation's inhabitants (citizens, companies and governments alike) on a shared infrastructure for energy distribution. ${ }^{82}$ In turn, all members of the 'household' are encouraged to help realize

\footnotetext{
${ }^{78}$ NMP2. (1994). Nationaal Milieubeleidsplan 2. Ministerie van Volkshuisvesting, Ruimtelijke Ordening en Milieubeheer, p. 7.

${ }^{79}$ NMP3. (1998). Nationaal Milieubeleidsplan 3. Ministerie van Volkshuisvesting, Ruimtelijke Ordening en Milieubeheer, p.31.

${ }^{80}$ Ibid., p. 61. This network perspective on the role of the government is fitting with the political culture of the Netherlands. As Hanf \& van de Gronden (1998, pp. 157-9) noted, the Dutch have a tradition of cooperation and consensus politics in which the national government tends to ask private organizations for advice on controversial issues. Departments of EZ and VROM have historically been surrounded by an 'iron ring' or advisory councils through which private organizations have an opportunity to influence policy decisions. See Kickert (2003) on the historical origins of the Dutch consensual style of governance.

${ }^{81}$ NL. (1998). Uitvoeringsnota Klimaatbeleid. Tweede Kamer: Nota 26603 (nr.2), p. 17.

${ }^{82}$ Scholars like John Urry (2003) and Manuel Castells (2010) have studied how the pervasiveness of flows (of objects, people and information) became a whole mark of the 'ecological dominance' of globalizing capitalism,
} 
domestic energy reform. Such shared responsibility was also at the heart of the new approach towards climate action which the Dutch government officially adopted in 2001: 'transition management.'

Transitions can be defined as long-term, gradual, continuous processes of structural societal change (Rotmans et al., 2000). Climate change was portrayed as an emblematic case, necessitating a Dutch energy transition: "addressing climate change has to be done by addressing the energy economy." ${ }^{83}$ As Rene Kemp, one of the intellectual founding fathers of the Dutch transition approach, noted:

"Initially, the energy transition was a self-contained process, largely separated from existing policies for energy savings and the development of sustainable energy sources. It is now one of the pillars of the overall government approach for climate change" (Kemp, 2010).

Transition management suggests that policies should look both broader (beyond national borders) and further ahead, taking 2030 or even 2050 as a horizon, "because realizing a sustainable balance in for example 30 years' time requires making choices in the present time." ${ }^{\prime 4}$ As a policy approach, transition management drew upon (and reinforced) the idea that the national government should act as a facilitator of changes which should, in the end, be realized in a broader network of businesses, societal groups and multi-level governments. ${ }^{85}$ Realizing energy reform was described as taking a collective journey:

"We (the society) want to travel 'South' (a sustainable energy economy) and are therefore looking for travel companions (active market players). At the moment, it is not so important where in the South we want to go exactly: one group may want to go to Rome, another to Africa (each party can have its own goals). We do not know which mode of transportation is most suitable: train, plane, automobile (keeping

undermining the legitimacy and power of traditional structures (e.g. national governments) to govern sociotechnical change.

${ }^{83}$ NMP4. (2001). Een wereld en een wil - Werken aan duurzaamheid. Ministerie van Volkshuisvesting, Ruimtelijke Ordening en Milieubeheer, p. 128.

${ }^{84}$ Ibid., p.6.

${ }^{85}$ See for example: "De effectiviteit van transitiebeleid staat of valt immers met de inzet en gedrevenheid van alle betrokkenen: overheid, bedrijfsleven, kennisinstituten en een scala van maatschappelijke groeperingen”. Source: SER. (2001). Advies over het vierde Nationale Milieubeleidsplan (NMP4). The Hague: Sociaal-Economische Raad, p. 37. Some considered 'transition management' to be a contradiction in terms: "It is suggested that we have gained enough experience to put in place or manage new transitions. This implies a governance pretence which the Council would like to play down. History shows that such processes of change, in which technologies often plays a crucial role, are difficult to steer and control” (VROM-Raad, 2001, p. 32). However, the acknowledgement that sociotechnical change cannot directly be controlled but can only be facilitated or governed is arguably at the heart of the transition approach. See also the scholarly exchange between Shove and Walker (2007) and Rotmans and Kemp (2008). 
options open). After a while, we will assess whether we are on the right track (feedback) and whether we have chosen the right vehicle (learning by doing). And by sending a postcard home, we may inspire those that stayed behind to join us on our journey (communicating success and experiences)." 86

CCS was never portrayed as the only road leading towards a sustainable energy future. From roughly 2000 onwards, Dutch policy documents sketch three main pathways: (i) lowering energy usage, (ii) switching to renewable energy and (iii) developing Schoon Fossiel. ${ }^{87}$ Often referred to as the 'Trias Energica's8, these three approaches continue to dominate the Dutch climate portfolio till the present day. Together, they make up the traditional Polder-mix (Van Est \& Verbong, 2007). ${ }^{89}$

According to the transition logic, all three pathways should be kept open and explored in a balanced way, without one dominating the other due to short-term considerations. ${ }^{90}$ In turn, the Dutch policy on Schoon Fossiel was initially one of "wait and see" (Turkenburg, 2004). This changed in 2004 with the introduction of a national Taskforce Energy Transition. This Taskforce was chaired by the president of Royal Dutch Shell. Other members included large energy companies, established research institutes like ECN and one environmental NGO: the relatively small 'Klimaatbureau.' The national Taskforce was asked to formulate in concrete and operational terms "which role sustainable energy could play in realizing a sough-after future energy supply, which technologies could support this role, which opportunities this would offer to Dutch companies and how these could be realized and utilized." ${ }^{11}$ In October 2005, the Taskforce set up a working group specifically for Schoon Fossiel. It involved representatives from the Ministries of VROM and EZ, fossil-

\footnotetext{
${ }^{86}$ EZ. (2002). Investeren in energie. Keuzes voor de toekomst (Energierapport 2002). Ministry of Economic Affairs, p. 82.

${ }^{87}$ See for example:Rijksoverheid (2011). 'Klimaatbrief 2050 - Uitdagingen voor Nederland bij het streven naar een concurrerend, klimaatneutraal Europa', Kabinetsaanpak Klimaatbeleid, November 2011.

${ }^{88}$ A term coined by Eric Lysen (1996), founder of the Center for Energy Research and initiator of CATO. Importantly, the term suggests that Schoon Fossiel is the least preferred option and should only be developed in case energy saving and renewables fall short. However, it is unclear how this ranking can be enforced in a networked nation, as I will argue in the remainder of this Chapter.

${ }^{89}$ At times, nuclear energy is added to this portfolio too. See for example: VROM, \& AER. (2004). Energietransitie: Klimaat voor nieuwe kansen. VROM-raad \& Algemene Energieraad.

${ }^{90}$ NMP4. (2001). Een wereld en een wil - Werken aan duurzaamheid. Ministerie van Volkshuisvesting, Ruimtelijke Ordening en Milieubeheer, p. 149. This is a persistent idea in policy advisory report on energy reform. See for example: "there is no magic bullet and we will need every presently known technology to address the issue [of climate change]" (Lenstra \& van Engelenburg in (IPCC, 2002, p. 115)). See also the influential article of Pacala and Socolow (2004) on the portfolio of available technologies that could be developed "to meet the world's energy needs over the next 50 years and limit atmospheric $\mathrm{CO}_{2}$ to a trajectory that avoids a doubling of the preindustrial concentrations".

91 Taskforce Energietransitie. (2006). Meer met energie - Kansen voor Nederland. Interim report, p.1.
} 
based energy companies, knowledge institutes (ECN, TNO, CATO) and one environmental NGO: Stichting Natuur \& Milieu.

Some have criticized the composition of the Taskforce Energy Transition for including mainly regime players, thus smothering the potential for radical system innovations (Rotmans \& Kemp, 2008, pp. 1007-8). Although the enrolment of political heavy-weights helped to spread the message and provided credibility to the Dutch transition approach, it also replicated the very kind of elite network structures which transition scholars suggest should be avoided (Hendriks, 2008). Looking at the Schoon Fossiel Working Group, a similar assessment could be made. Its sudden introduction, without much public debate, was described by a representative of a Dutch environmental NGO as "an illustration of the total corruption of the transition by vested interests" (quoted in A. Smith \& Kern, 2009, p. 94). ${ }^{92}$ In any case, both the Taskforce Energy Transition and the related Schoon Fossiel Working Group underlined the idea that a network of actors, instead of the national government alone, was considered responsible for shaping the Dutch energy future.

\subsubsection{From wait-and-see to a CCS Task Force}

Drawing on scenario studies by the IPCC and IEA, members of the Schoon Fossiel Working Group emphasized that CCS could realize between 15 and $55 \%$ of the global $\mathrm{CO}_{2}$ emissions reductions needed by 2100 . It was estimated that the Dutch underground could accommodate $\mathrm{CO}_{2}$ emissions from all large sources in the Netherlands for 175 years (!) to come. Given its experience with handling natural gas flows, the nation could become an international frontrunner on $\mathrm{CO}_{2}$ storage too. ${ }^{93}$ But making large-scale CCS 'work' in the Netherlands entailed several challenges. ${ }^{94}$ Early projects faced a first-mover disadvantage, as they required considerable investments in infrastructure and faced the risk of local opposition. The Dutch government was therefore urged to abandon its 'wait and see attitude' and take on an active role by reserving abandoned gas fields for future $\mathrm{CO}_{2}$ injection (so-called

\footnotetext{
${ }^{92}$ By focusing on frontrunners, radical innovation and niche players, transition management tried to break with the institutionalized consensual style of policy-making. Derk Loorbach, Professor of Socio-Economic Transitions, therefore described the Dutch government's explicit adoption of the transition philosophy as a 'governance experiment', in the sense that it could also turn out to be merely "another fashionable governance innovation that is being used to cover up that in the meantime, it is still policy as usual" (Loorbach, 2010, p. 163; see also Vollenbroek, 2002; Hendriks, 2008). This is perhaps not surprising, since CCS was supposed to be developed within the existing, fossil-based energy regime and thus relied on the enrolment of dominant regime players (e.g. energy companies and heavy industry).

${ }^{93}$ Werkgroep Schoon Fossiel. (2006). Advies van de werkgroep Schoon Fossiel van het Platform Nieuw Gas aan de Taskforce Energietransitie, p.15.

${ }^{94}$ See also: Ecofys. (2007). Making large-scale CCS in the Netherlands work: An agenda for 2007 - 2020. Ecofys.
} 
'moth-balling'), subsidizing CCS demonstration projects and providing clarity on the judicial and technical requirements that such projects would have to meet. And, to reduce the risk of local opposition, the Dutch government was urged to "guarantee a sufficient level of safety" regarding CCS by putting a clear regulatory framework in place. ${ }^{95}$

If the national government would not take on its prescribed role as facilitator, CCS would only play a marginal role in the Netherlands. In the short term, this would hardly have negative consequences. However, the Working Group warned that there was a risk for the longer term:

"Our country will lose knowledge- and innovation power. Furthermore, there are opportunity costs involved, as the chance of competitive sector-development is wasted. ... Not substantially activating the CCS option in the short term will place much greater pressure on the few sustainable options for realizing $\mathrm{CO}_{2}$ emission reductions domestically (like energy saving, wind energy and biomass, but possibly nuclear energy too)." ${ }^{\prime 6}$

So, slow implementation of CCS could lead to missed income in the longer term (or worse, to the expansion of nuclear energy).

In 2008, a public-private Taskforce on CCS was installed, chaired by the former Directorate General 'Energy' of the Ministry of EZ. This CCS Taskforce had a more hands-on approach compared to the previous CCS Working Group. Members included political heavy-weights from the regions Rotterdam and Groningen, the presidents of energy companies Electrabel and Shell-NL, the Scientific Director of Ecofys, the chair of Stichting Natuur \& Milieu and the project-director CCS at VROM/EZ. They urged the Dutch government to act as a 'transition manager' by drafting a master plan for CCS infrastructure development. ${ }^{97}$ Execution of this plan should be managed by semi-public parties like Gasunie and Energie Beheer Nederland, which had earlier done so for the national gas infrastructure. Two large-scale demonstration projects were foreseen in Rotterdam and Northern-Netherlands, which should help to make CCS commercially available by 2020 . But tensions were flagged as well. Although CCS was considered necessary to realize the Dutch climate objectives, the Taskforce argued that actual application of CCS should be governed by market-based instruments (i.e. EU-ETS) and goal- instead of technology-based

\footnotetext{
${ }^{95}$ Werkgroep Schoon Fossiel. (2006). Advies van de werkgroep Schoon Fossiel van het Platform Nieuw Gas aan de Taskforce Energietransitie, p.12. Chapter 3 will study the contested decision-making on the main onshore CCS demonstration project to better understand why it was so difficult to come to an authoritative verdict on safety. ${ }^{96}$ Ibid., p. 23.

${ }^{97}$ Taskforce CCS. (2009). Advies van de TaskForce CCS inzake de organisatie van de transport- en opslaginfrastructuur. TK 081-2009: Taskforce CCS. See also: McKinsey. (2009). Large scale roll out scenarios for CCS in the Netherlands: 2020-2050. Final report for the Ministry of Economic Affairs and the Ministry of Housing, Spatial Planning and the Environment, p. 69.
} 
regulations at the EU level. So, commercial parties should not be forced by the Dutch government to capture and store their $\mathrm{CO}_{2}$ emissions. ${ }^{98}$

In sum, it was considered the responsibility of the national government to put favorable systematic conditions in place for energy transitions to occur. But commercial partners would then have to select, travel and construct the pathways which they themselves deemed most appropriate. The Ministry of Economic Affairs described the responsibilities as such:

"The Dutch Cabinet does not provide a blueprint for the energy system of 2050. The government formulates objectives and conditions, it stimulates and directs. The market invests and thereby determines the energy mix." ${ }^{\prime 9}$

The Dutch energy future would (and should) ultimately be determined by a network of actors, operating in a European market. ${ }^{100}$ Nevertheless, the development of a domestic infrastructure for CCS was considered necessary, as this could yield (for the nation as a whole) economic and environmental benefits in the longer term. How could closure on CCS be realized in this networked nation?

\subsection{REALIZING CLOSURE IN AN OPEN ECONOMY}

The Dutch political culture has long been characterized by the 'Poldermodel.' Polders refer to the low parts of the country, which, being vulnerable to flooding, traditionally require a high level of collaboration to keep them safe for their inhabitants. The associated political culture is one in which dialogue and collaboration are essential to develop new policies

\footnotetext{
${ }^{98}$ Taskforce CCS. (2010). Advies inzake aanvullend instrumentarium CCS. TF008-2010: Taskforce CCS. According to Vergragt (2009a, p. 200), the Taskforce understood achieving public acceptance of CCS "as one of its most important tasks”, but did little to make this a reality. More on public acceptance in Chapter 3.

${ }^{99}$ Source: EZ (2008). Energierapport 2008. Ministry of Economic Affairs, p. 11.

100 This shift in imagined responsibility is not unique for the Dutch government and can arguably be placed in a broader context. In his book on Governmentality, sociologist Mitchell Dean (2010) notes for example that the end of the $20^{\text {th }}$ century (the period which Ulrich Beck called 'reflexive modernization') was characterized by a broad shift away from traditional government of national economies towards a form of 'reflexive government'. In Western democracies at least, the task of national governments is no longer the management of self-regulating national economies to secure benefits to 'society', conceived as the totality of members of a national population. The task is instead to reform those individual and institutional conducts that are considered likely to affect economic performance compared with that of other national or even regional populations (Ibid, p. 247-8). Indeed, realizing sociotechnical change remained at the heart of the Dutch 'reflexive' governance approach. However, it no longer sought to achieve this through direct intervention in processes (i.e. regulating the domestic fuel mix for electricity production) but through changing the mechanisms, techniques and agencies of government themselves (i.e. through the introduction of the EU-ETS and further liberalization of the European energy market).
} 
faced with different and sometimes competing societal interests (Kok et al., 2002, p. 7). In turn, voluntary agreements with commercial parties have become a typical way of governing the Dutch polder (Hanf \& van de Gronden, 1998, p. 169; Bressers \& de Bruijn, 2005). In 1994, efforts to negotiate a $\mathrm{CO}_{2}$ covenant with the electricity sector were temporarily put on hold, as the anticipated liberalization of the energy market would introduce too many uncertainties to come to such a long-term agreement. In 1999, a benchmarking covenant was signed with heavy industry on increasing energy efficiency. And in 2002, a covenant was signed with electricity producers on the use of biomass. Realizing a covenant on CCS proved more difficult though. Although the prospect of CCS has played an important role in the Dutch energy policy from 2001 onwards, the uncertain economic outlook made it difficult to negotiate a covenant with the power sector. Commercial parties felt that CCS technologies (although "by themselves familiar") were "immature" due to lack of practical experience and emphasized that demonstration projects were needed. ${ }^{101}$ At the same time, the economic benefits of participating in (and co-funding) such projects were uncertain, because they depended on the future price of $\mathrm{CO}_{2}$ as determined by political interventions at the EU level.

Introduction of the EU-ETS made voluntary agreements and national emission reduction targets less effective means for governing socio-technological change domestically. ${ }^{102}$ How then was closure on CCS pursued? As the next section will show, visions and metaphors played a crucial role. Obviously, I do not claim that these were the only means for realizing closure on CCS. EU-wide instruments like R\&D subsidies and direct regulation on 'capture-readiness' of new coal plants played an important role too. ${ }^{103}$ Still, I focus on the role of visions and metaphors because these provide clues for understanding both the 'necessity' and the slow implementation of CCS in the Netherlands.

\footnotetext{
${ }^{101}$ EZ \& VROM. (2003). Beleidsnotitie “Schoon fossiel." TK 2003-2004, 28 241, no. 6. I will return to the 'readiness' of CCS and the lessons learned in CCS demonstration projects in Chapter 4.

${ }^{102}$ Already in 2003, ECN argued for example: "Regardless the method of allocating allowances, the Benchmarking Covenant could be considered to be abolished once the EU-ETS becomes operational, since there are no convincing reasons to continue its existence... alongside the EU-ETS”. Source: Sijm \& van Dril (2003). The interaction between the EU emissions trading scheme and energy policy instruments in the Netherlands. ECN, no. ECN-C-03-060, p. 11.

103 The Dutch government has, together with the UK, actively tried to make CCS development an EU priority. Other member states, like nuclear-dependent France and Southern-European countries with fewer geological $\mathrm{CO}_{2}$ storage locations, were reluctant to support research and development of CCS through public funding though (Fischer, 2012). Gjefsen (2013) argues that EU policies on CCS were guided by an imaginary of 'europeanization'.
} 


\subsubsection{A bridge or a dead end?}

As an environmental policy approach, transition management drew upon (and further strengthened) the idea that no party could or should provide a blueprint of the national energy future. ${ }^{104}$ The Dutch government thus deliberately decided not to single out a promising pathway. It would be misguided to characterize this as a 'non-imaginary' though. The opposite is arguably true. Given that it is considered impossible to unilaterally and wilfully re-design the Dutch infrastructure for handling energy flows, visions became crucial in mobilizing societal resources, capturing collective enthusiasm and bridging competing interests necessary for realizing energy reform in the Netherlands.

Under transition management, visions are used to encourage societal actors to realize more sustainable sociotechnical systems (Kemp, Rotmans, \& Loorbach, 2007). In its NMP4 of 2001, the Dutch government for example sketched three visions of what the national energy system might look like in 2030. ${ }^{105}$ First, Status Quo meant that the existing infrastructure would remain largely unchanged. Natural gas, oil and electricity would remain the final energy carriers as purchased by Dutch consumers, although the primary flows could be of renewable or 'cleaned' fossil origin. Second, there was the vision of the Netherlands as a hydrogen land. This would require an all-or-nothing transformation, where renewable, nuclear and fossil energy sources would be used for large-scale production of hydrogen. Third, the Netherlands could become an electricity land. This too would require a fundamental change to the energy infrastructure, as large-scale sociotechnical systems for decentralized production, electric cars, heat pumps and underground $\mathrm{CO}_{2}$ storage would need to be put in place. ${ }^{106}$ In all these visions, CCS played an important role. However, developing CCS also entailed a tension.

\footnotetext{
${ }^{104}$ See also: "In the eyes of the authors, the term 'blueprint' does not imply that the future energy supply can be designed and realized according to a master plan. The blueprints are only meant to inform analyses and to structure discussions. Therefore, they are designed in such a way that the entire playing field of options is covered" (ECN, \& RIVM. (2000). Perspectives for energy and mobility in the Netherlands in 2030. ECN \& RIVM, p.5). And: "Especially in the initial phase, the formulation of end state visions can go hand in hand with the development of new energy technologies. So, end state visions are not synonymous with rigid blueprints" (SER. (2001). Advies over het vierde Nationale Milieubeleidsplan (NMP4). The Hague: Sociaal-Economische Raad, p.42.). Rotmans and Kemp (2008, p. 1006) also emphasize that transition management was developed "as a cyclical process of searching, experimenting, and learning, merely as a response to deterministic, blueprint-based steering methods used during the last decades".

${ }^{105}$ NMP4. (2001). Een wereld en een wil - Werken aan duurzaamheid. Ministerie van Volkshuisvesting, Ruimtelijke Ordening en Milieubeheer. This report drew heavily on a study by Rotmans et al. (2000).

${ }^{106}$ Energy visions have to balance particular (and sometimes conflicting) values, like sustainability or 'cleanliness', reliability/security, affordability and competitiveness. Actors often disagreed on the precise interpretation of these values (Ramirez et al. 2008). It is therefore not surprising that other visions were formulated too. The Dutch
} 
Transition management aimed for radical reform of the Dutch energy system. But it was unclear whether and how large-scale CCS would contribute to this. Rotmans et al. (2000) argued for example that the 'Status Quo' vision entailed too little change to count as a transition. ${ }^{107}$ Although part of their policy-advisory report was reproduced verbatim, this particular qualification was not copied by the Dutch government. ${ }^{108}$ The NMP4 stressed instead:

"Although the term implies the opposite, the 'Status Quo' vision will require major transformations: massive amounts of produced synthetic gas and captured $\mathrm{CO}_{2}$ will have to be stored in, amongst others, depleted gas fields." 109

In 2003, the Ministries of EZ \& VROM went even further and argued that the introduction of a large-scale infrastructure for CCS could be considered a transition by itself:

"If Schoon Fossiel starts to play a substantial role in the energy supply, this will entail a substantial change to the existing energy infrastructure. In fact, it will constitute an energy transition." 110

So, some argued that CCS development was legitimized because it constituted an energy transition by itself. But others (e.g. Greenpeace) reasoned from a different long-term vision. They equated a 'sustainable' energy economy with a renewable-based energy economy, in which fossil fuels and CCS would not play a role anymore. ${ }^{111}$ To accommodate both viewpoints, policy papers started to portray Schoon Fossiel as a metaphorical bridge towards a truly sustainable energy future. ${ }^{112}$

Energy Council, an independent policy advisory body, for example sketched four different visions: (i) Netherlands natural gas land, (ii) Netherlands $\mathrm{CO}_{2}$ storage land, utilizing depleted natural gas fields and Dutch geological expertise, (iii) Netherlands at sea, using the harbour of Rotterdam to attract and handle fossil and biomass streams and (iv) Netherlands knowledge land, drawing on high-tech expertise in the field of e.g. solar cells. It was suggested that all four visions could be pursued, as they arguably strengthened the nation's competitive advantages and allowed for sustainable economic growth in a liberalized energy market.

${ }^{107}$ For a detailed discussion on the relation between CCS and carbon lock-in, see e.g. Vergragt (2009b) and Unruh (2000).

${ }^{108}$ I take this point from Smith \& Kern (2009, p. 85).

${ }^{109}$ NMP4. (2001). Een wereld en een wil - Werken aan duurzaambeid. Ministerie van Volkshuisvesting, Ruimtelijke Ordening en Milieubeheer, p.153.

${ }^{110}$ EZ \& VROM. (2003). Beleidsnotitie “Schoon fossiel.” TK 2003-2004, 28 241, p. 17.

${ }^{111}$ See for example: CE-Transform. (2003). Dialoog om de diepte: Eindverslag klankbordgroep CRUST/CO ${ }_{2}$-opslag. CE-Transform. And: " $\mathrm{CO}_{2}$-storage is more expensive than energy saving and does not result in a transition towards a sustainable energy supply”. Source: Milieudefensie. (2005). Subsidiëren van $\mathrm{CO}_{2}$-opslag: Een keuze voor de doodlopende weg van fossiele brandstoffen. Amsterdam: Friends of the Earth/CE-Delft.

${ }^{112}$ AER. (2002). Post-Kyoto Energiebeleid - Advies aan de Minister van Economische Zaken. Algemene Energieraad, p. 28. And: EZ \& VROM. (2003). Beleidsnotitie “Schoon fossiel.” TK 2003-2004, 28 241, p. 10. See also Minister of EZ, Toezegging uit AO van 9 november 2005 betreffende Schoon Fossiel, 7 December 2005, E/EP / 5716306 and Ministers of EZ \& VROM (2009), Beleidsbrief Schoon Fossiel, ET/ED 9110811. 
Describing CCS as an intermediary 'bridge' helped to accommodate two expectations: (i) fossil fuels will eventually be replaced and (ii) fossil fuels will remain abundantly available for decades to come. A graph started to circulate, depicting CCS as a "necessary intermediary step in the transition" (see Figure 6 below). ${ }^{113}$

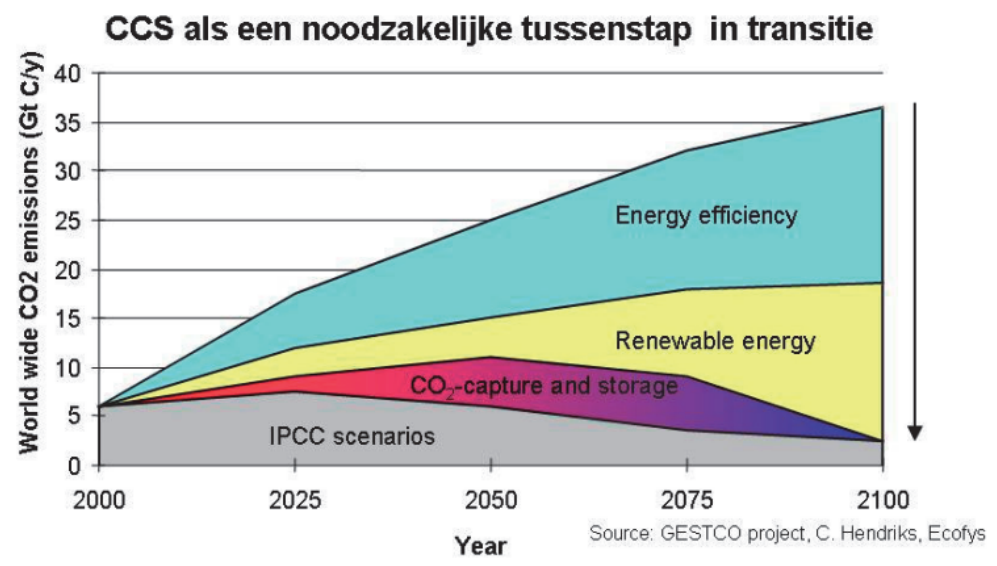

Figure 6: Graph depicting CCS as a necessary intermediary step Source: Ecofys. (2007). Making large-scale CCS in the Netherlands work. Ecofys.

The ambiguity of the 'bridge' metaphor should be highlighted. Its imagined size and length were only partially based on expectations regarding fossil scarcity and technology development. Expectations on the future socio-political order played an important role too. The graph suggested for example that CCS would be a 'back-stop' option, developed only after maximum efforts were made to advance energy efficiency and renewable energy. However, it was unclear how this ordering could be ensured in a networked energy economy. ${ }^{114}$ Additionally, the graph depicted the potential global role of CCS. Translating this to the Dutch situation, with its abundant $\mathrm{CO}_{2}$ storage capacity, unavoidably involved a form of wishful thinking. ${ }^{115}$ Some environmental groups felt that CCS should cease to play a role in the

\footnotetext{
${ }^{113}$ This graph was for example used by the Project Director CCS at EZ/VROM when communicating the necessity of CCS in general and Shell's CCS demonstration project specifically to inhabitants of Barendrecht. More on this project in Chapter 3.

${ }^{114}$ Some scenario studies suggested CCS would out-compete renewable energy and would therefore delay their implementation. ECN researchers concluded therefore: "CCS will not function as a bridge to fully renewable energy systems" (de Coninck et al., 2006, p. 30).

${ }^{115}$ EDN. (2009). $\mathrm{CO}_{2}$ afvang en -opslag: Vijgenblad, noodzakelijk kwaad of wereldkans? - Eindrapport EDN CCS Dialoog. Energie Dialoog Nederland, p. 24-5.
} 
Netherlands by 2050. ${ }^{116}$ But some industrial groups argued that CCS could play a role even after 2100. Members of the Schoon Fossiel Working Group had for example used the graph below (Figure 7) to underline that CCS could be attractive for 'de BV Nederland' for decades to come.
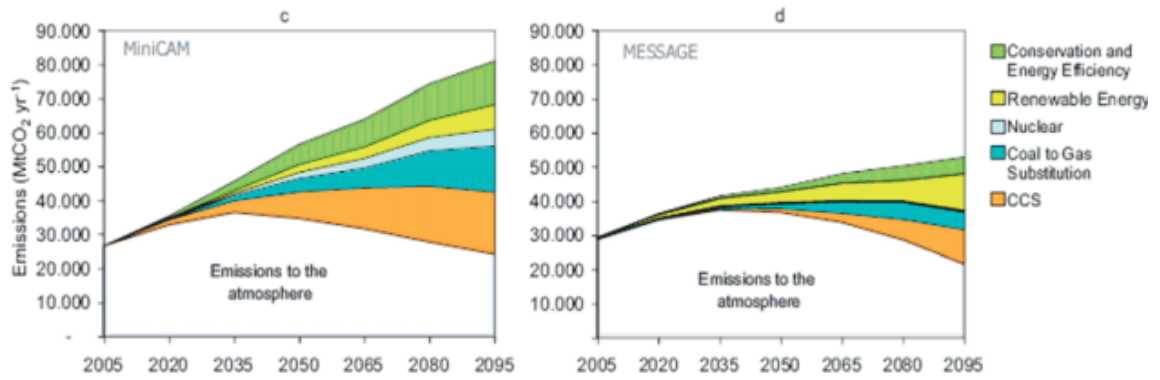

Figure 7: Illustration of the potential global share of CCS, depicted as a final option under GHG policies. Source: Werkgroep Schoon Fossiel. (2006). Advies van de werkgroep Schoon Fossiel van het Platform Nieuw Gas aan de Taskforce Energietransitie, p. 14

Although (or perhaps: because) its size and length were ambiguous, the 'bridge' metaphor helped to communicate to all groups that developing CCS was both a global necessity and a national opportunity. At the same time, it was acknowledged that no party could unilaterally decide on the future share of CCS in the Netherlands. Energy reform would have to be realized by commercial companies, operating within an international energy market. In turn, visions of hubs and roundabouts started to play an important role in inspiring projects and in realizing closure on CCS.

\subsubsection{Visions of hubs and roundabouts}

By 2005, the EU-ETS had created an artificial market for $\mathrm{CO}_{2}$ allowances. ${ }^{117}$ The dominant expectation was that $\mathrm{CO}_{2}$ emissions would, through political intervention, gradually

\footnotetext{
${ }^{116}$ Ecofys. (2007). Sustainability framework for carbon capture and storage. Utrecht: Ecofys \& Copernicus Institute for Sustainable Development and Innovation, p.30. Note that Greenpeace has long tried to reframe the pathway of Schoon Fossiel as a "dead end" instead of a bridge. Greenpeace. (2005). Energy revolution: A sustainable pathway to a clean energy future for Europe (A European energy scenario for EU-25). Greenpeace International, p.3. See also: Greenpeace. (2010). CO2-dumpen: waarom niet?. Greenpeace Netherlands.

${ }^{117}$ In the Netherlands, most societal groups expected that the EU-ETS would play a key role in governing CCS implementation (Ecofys, 2007; Green4Sure, 2007; EZ, 2008; McKinsey, 2009; PBL, 2009; RMNO, 2010; PBL \& ECN, 2011)).
} 
become more expensive. In turn, early investment in CCS turned from an expensive 'regret' option into an economic opportunity. If capturing and storing $\mathrm{CO}_{2}$ in the underground would be cheaper than buying allowances, a competitive advantage could be gained. After introduction of the EU-ETS, visions of $\mathrm{CO}_{2}$ hubs and roundabouts started to circulate in the Netherlands. In 2007, the Schoon Fossiel Working Group argued that they would allow the nation to capitalize on its knowledge of both the deep underground and of handling fossil flows. ${ }^{118}$ In 2009, the Ministry of Economic Affairs noted:

"The Netherlands [aims] to become a hub in a more sustainable energy supply, a 'round-about' where technology, production, trade and knowledge come together. ... In the short term, this energy transition will come at a price. But if investments are not made in the present, the costs will be much higher in the long term. There are abundant opportunities for business and knowledge institutes. ... CCS can help to attract economic activity to the regions of Rotterdam and Eemshaven. ... Industry offers a world of solutions for the major energy problems that we face today." 119

And indeed, the vision of a $\mathrm{CO}_{2}$ roundabout proved a powerful way for bridging competing interests and bringing societal groups together. This is most visible in the region Rotterdam-Rijnmond.

Rotterdam is home to one of the biggest harbours in the world, specialized in handling fossil flows. Already in 2003, policy-advisors noted a dilemma for the region's long-term future. The question was not so much whether renewable energy would eventually take over the role of fossil fuels, the main question was when. Estimations on this varied significantly. The dilemma (called 'to C or not to C') was therefore whether Rotterdam should make an anticipatory switch to facilitate new, low-carbon energy flows (e.g. biomass) or should try to prolong its position as a carbon-intensive port by efficiently and cleanly handling fossil flows. ${ }^{120}$ Rotterdam opted for the latter approach and positioned itself as a national 'transition garden' for Schoon Fossiel. In 2007, the Rotterdam Climate Initiative (RCI) was initiated by the City of Rotterdam, the Port Authority, the regional Environmental Protection Agency DCMR and industry organization Deltalinqs. Aim was to turn Rotterdam into the world capital of $\mathrm{CO}_{2}$-free energy. As the Program Director of RCI put it:

\footnotetext{
${ }^{118}$ Werkgroep Schoon Fossiel. (2007). Beleidsrapportage Schoon Fossiel: Advies van de werkgroep Schoon Fossiel, p.23.

${ }^{119}$ EZ. (2008). Energierapport 2008. Ministry of Economic Affairs, p.5 - 16.

${ }^{120}$ Bosma, A., Brouwer, G., Diepenmaat, H., Jordan, C., Soest, J. P. van, Toledo, G. van, \& Weiden, A. van der. (2003). "To C or not to C, that's the question...": Laveren tussen continuïteit en vernieuwing in het Rotterdamse haven-industrieel complex.
} 
"We're unleashing a new industrial revolution here." 121

An ambitious quantitative target was negotiated too: regional $\mathrm{CO}_{2}$ emissions would be reduced with $50 \%$ by 2025 compared to $1990 .{ }^{122}$ CCS played a crucial role in the envisaged 'revolution.' ${ }^{123}$ In the words of Ruud Lubbers (former Prime Minister of the Netherlands and quartermaster of the RCI):

"CCS was, and still is, essential for achieving our $50 \%$ objective. It will remain the foundation of the RCI." 124

In turn, a vision was formulated in which Rotterdam would become a European, and perhaps even global, $\mathrm{CO}_{2}$ hub. ${ }^{125}$

${ }^{121}$ Wiert-Jan de Raaf (RCI) and Maarten de Hoog (DCMR), quoted in: Port of Rotterdam (2010), 'Rotterdam Energy Porty', Port Special, June 2010, p. 21.

122 Paradoxically, the stringent $\mathrm{CO}_{2}$ target allowed for business-as-usual. As the former chairman of ROM-

Rijnmond (precursor of RCI) put it: "The advantage of this objective was: you can continue business-as-usual and the problem will be solved. That was in the interest of industry. You facilitate that they continue their activities. So it does not structurally change the energy system. That is why it was embraced as a concept." (interview GB, 2012). More on this below, in the section 'The performativity of expectations'.

${ }^{123}$ Historian of technology David Edgerton (2006) argues that a lot of 'innovation' is done not by radical change and invention but by adapting old technologies to present-day conditions. Linking CCS to coal-fired power plants is arguably a case in point.

${ }^{124}$ Written correspondence, Ruud Lubbers, Quarter Master RCI, 2012.

125 "Given the favourable location factors in Rotterdam (i.e. the vicinity of nearly depleted gas fields, BvO) and the cost-benefit analysis, one can conclude that the vision of Rotterdam as a global $\mathrm{CO}_{2}$ hub is realizable." Source: RCI. (2007). $\mathrm{CO}_{2}$-afuang en opslag in Rijnmond. Rotterdam Climate Initiative, p. 57. 


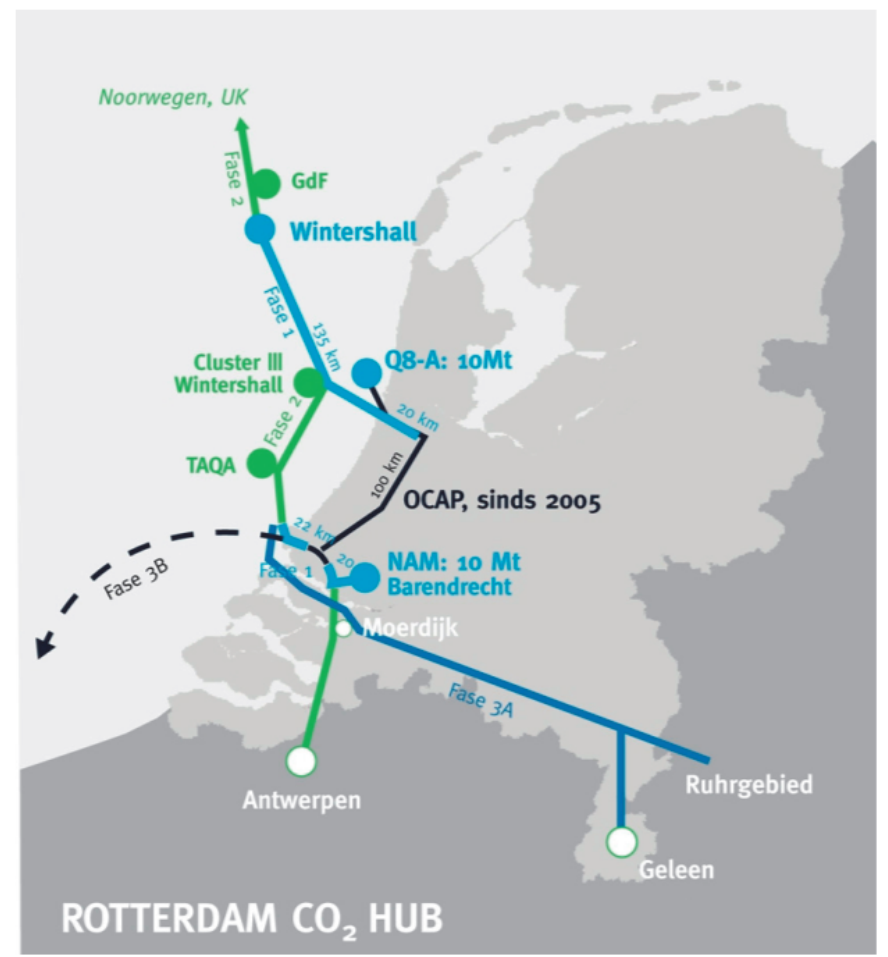

Figure 8: Vision of a Rotterdam $\mathrm{CO}_{2}$ hub Source: RCI (2008), $\mathrm{CO}_{2}$-afvang, -transport en -opslag; Rapportage 2008, Rotterdam Climate Initiative, p. 37.

Images of hubs and roundabouts were drafted on other occasions too. Already in 2005, plans were made to update the Dutch gas infrastructure. This should allow for more transboundary transport and for temporary gas storage. The Ministry of EZ sketched an image of the nation as a 'gas hub':

"The Netherlands wants to take full advantage of its position as a gas nation. The country should increasingly become a hub for international gas trade." 126

The image of a hub was evoked in pleas for new coal gasification facilities and hydrogen production too. ${ }^{127}$ And when new coal-fired power plants were build in Northern Netherlands, a rather crude sketch of a $\mathrm{CO}_{2}$ roundabout was added (Figure 9).

\footnotetext{
${ }^{126}$ EZ. (2005). Nu voor later - Energierapport 2005. Ministry of Economic Affairs, p.11.

${ }^{127}$ AER (2008). 'Brief aan Minister van EZ: Waterstof uit kolen'. Algemene Energieraad, 2 September 2008, $08 / 567$.
} 


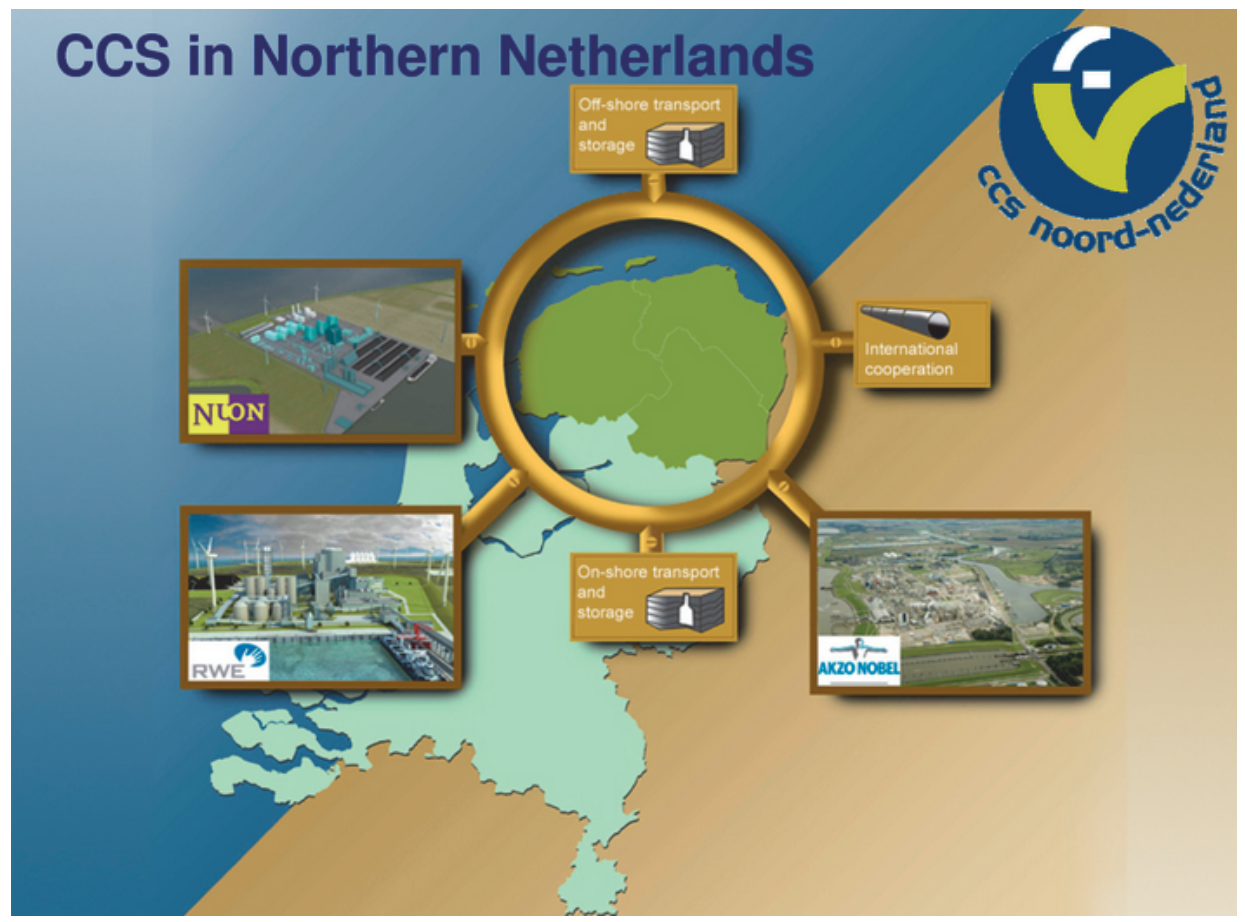

Figure 9: Slide used in public communications, sketching a future $\mathrm{CO}_{2}$ roundabout in Northern Netherlands. Source: CATO. (2009). Catching carbon to clear the skies: Experiences and highlights of the Dutch R\&D programme on CCS. Utrecht: Dutch CATO Program.

One may question whether the idea of a roundabout could easily be applied to $\mathrm{CO}_{2}$. Other than natural gas, $\mathrm{CO}_{2}$ is essentially a waste product. That is: every transformation (e.g. purifying the stream or monitoring post-injection behaviour) only adds costs without increasing the product's value. As the former Project Director CCS at EZ \& VROM put it in retrospect, this presented a problem for realizing the $\mathrm{CO}_{2}$ roundabout:

"Like the gas round-about, that $\mathrm{CO}_{2}$ round-about was a concept that was difficult to realize. I think that we were capable, and also had scenarios, to for example import $\mathrm{CO}_{2}$ from Antwerp or the Ruhr area. ... We had sketched such a ring. We could also undertake some activities in Northern Germany. We had ideas, but in the end, you don't make any money with CCS. It is simply a debit entry. It sounds appealing, a $\mathrm{CO}_{2}$ round-about, but you have to realize that you are in the waste business and not in the oil business, where a lot of money can be made. You are at the end of the chain, you will have to do everything at the lowest margin costs, be- 
cause every eurocent that you spend is one too many. So I think that the idea was there at the time, but that it was never going to work. (Interview HB, 2013)"128

Again, one may question whether visions of $\mathrm{CO}_{2}$ hubs and roundabouts can be realized. However, it is arguably their symbolic value which makes them powerful ways of imagining energy reform in the Netherlands. They resonate with the collective experience of putting a national infrastructure for natural gas distribution in place in the 1960s. As such, these images draw upon (and rehearse) the idea that the Netherlands is a networked nation, prosperous by being an 'open' place for fossil energy flows.

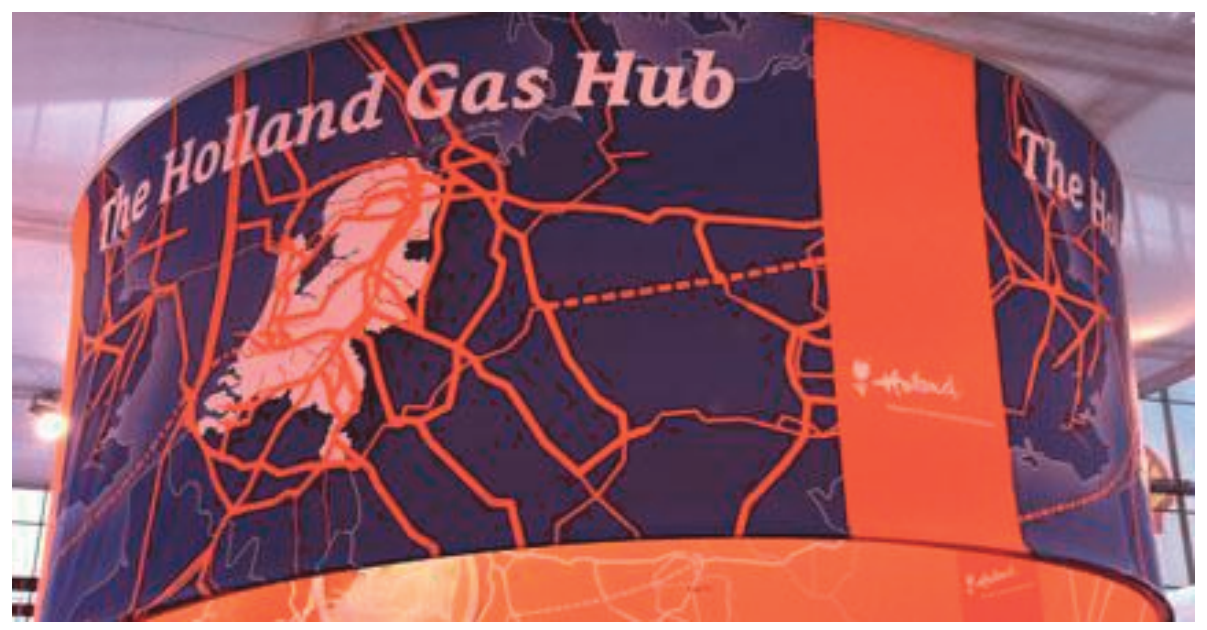

Figure 10: Stand by the Dutch government on a Natural Gas Fair (2010), depicting the nation in orange as 'the Holland Gas Hub.'

The relation between visions of $\mathrm{CO}_{2}$ hubs and the 'necessity' of CCS can now be highlighted, focusing again on the region of Rotterdam.

\subsubsection{The performativity of expectations}

By 2005, the EU-ETS had turned $\mathrm{CO}_{2}$ into a tradable commodity. For the Port Authority of Rotterdam, this meant that it could capitalize twice on handling fossil flows. As the Head of Energy \& Processing Industry put it:

\footnotetext{
${ }^{128}$ See also: "For several reasons, CCS will never have the same level of public support as the natural gas transition of the 1960s. ... There is no win-win situation: CCS will remain expensive and fundamentally wrong in the eyes of some”. Source: RMNO. (2010). De volle zaaiershanden - Eindrapport van Project Energie \& Duurzaamheid. The Hague: Raad voor Ruimtelijk, Milieu- en Natuuronderzoek, p. 26. Rotmans (2011) made a similar argument.
} 
"We formulated a regional climate objective, which may act as a flywheel [for CCS development]. But what we are actually saying: we are the energy port of NorthWestern Europe. We are handling fossil flows. And the harmful component of this, once captured, can be transported back in a reverse hub, in an infrastructure that we're happy to develop. (...) So the $I$ have a dream is that $\mathrm{CO}_{2}$ becomes another major stream in our books. In fact, it already is. It's just encapsulated in oil, coals and gas [laughs]. We are already handling hundreds of millions of tons of fossil streams, part of which consists of carbon. And what we're saying: this $\mathrm{CO}_{2}$, which is now considered to be harmful, should actually be brought back. That way, we twice make a profit on $\mathrm{CO}_{2}$, to put it bluntly" (interview $\mathrm{RM}$ ).

For the Port of Rotterdam, developing a regional $\mathrm{CO}_{2}$ hub made economic sense. It was attractive for energy companies and heavy industry to embrace this vision. In fact, subscribing voluntarily to the RCI's stringent $\mathrm{CO}_{2}$ targets helped to legitimize carbon-intensive activities in the region. When GDF SUEZ and E.ON for example unfolded plans to construct new coal-fired power plants, they negotiated operating conditions with the Municipal government of Rotterdam. Both companies made public promises to store part of their $\mathrm{CO}_{2}$ emissions in the future (if this was economically viable) and to participate in an offshore CCS demonstration project, co-funded by the EU and the Dutch government. As the Project Manager of one of these companies explained, participation in this project was based on a belief rather than a clear-cut cost-benefit analysis:

"At the moment, there is no profitable business case. This project is costing us millions of Euros. The question is: what are the benefits? In this R\&D project, we are talking about knowledge creation, but also about good will, publicity and reputation. You are an innovative company, starting new development. In the end, investment in CCS is a strategic choice in which the belief that CCS will be able to stand on its own feet after the demonstration phase plays an important role. Otherwise, the knowledge gained in this project will be of little value. We still believe in CCS and are convinced that fossil fuels will play an important role in the energy transition: during the transition, fossil fuels will have to be used as cleanly as possible and CCS is going to play an important role in achieving this." (interview AS, 2011)

The performativity of this expectation must be highlighted, in the sense that it helped to construct the regional and national necessity of CCS.

Techno-economic studies by RCI partners indicated that $20 \mathrm{Mt} \mathrm{CO}_{2} /$ year could be captured and stored at reasonable costs by 2025 . In turn, Rotterdam could become a major $\mathrm{CO}_{2}$ hub. Controversially, this vision legitimized that regional $\mathrm{CO}_{2}$ production would actually increase between 2009 and 2025 (see Figure 11). 


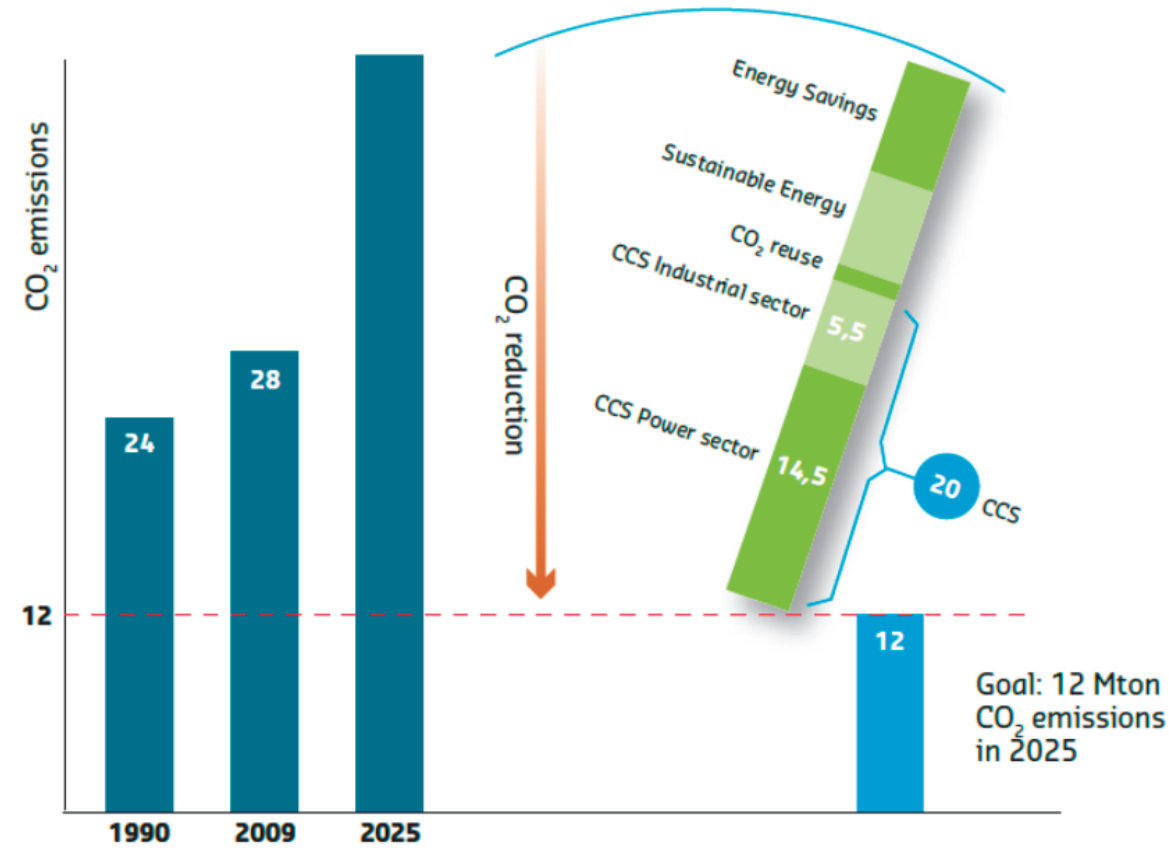

The $\mathrm{RCl}$ projects that CCS will contribute more than half of Rotterdam's emissions reductions target

Figure 11: Graph depicting the expected share of CCS in achieving the regional climate target Source: RCI (2010), $\mathrm{CO}_{2}$ capture and storage in Rotterdam: A network approach, Rotterdam Climate Initiative, p.5

The power plants of GDF SUEZ and E.ON would emit 3.8 and 5.6 $\mathrm{Mt} \mathrm{CO}_{2} /$ year respectively. ${ }^{129}$ With a stringent emission reduction target in place and the permits for these new coal plants granted, regional implementation of CCS became a 'necessity.'

A similar dynamic is visible at the national level. Around 2005, energy companies requested the expansion of domestic coal usage, arguing that this would decrease the vulnerability of the Dutch energy economy. ${ }^{130}$ In granting this wish, the Ministry of EZ stated in deterministic fashion:

\footnotetext{
${ }^{129}$ Or as Greenpeace put it: the equivalent of adding 2 million extra cars to the Netherlands. Such calculations are notoriously tricky to make though, as electricity production is a tightly coupled system: state-of-the-art coal facilities were expected to replace older (less efficient and more polluting) power plants by way of the Dutch merit order.

${ }^{130}$ VROM. (2005). Onderweg naar Kyoto - Evaluatienota Klimaatbeleid. VROM, p.19. For a similar line of reasoning, see AER (2008). 'Brief aan Minister van EZ: Waterstof uit kolen'. Algemene Energieraad, 2 September 2008, 08/567. See also: EZ (2008) Energierapport 2008. Ministry of Economic Affairs.
} 
"In the future, it will be possible to capture and safely store $\mathrm{CO}_{2}$ emissions of coalfired power plants." 131

The expectation that CCS could and would be applied in the future played an important, justificatory role: it legitimized the construction of new coal-fired power plants, because CCS would reduce the associated climate risk to an acceptable level. However, mandating CCS entailed an economic risk too, as capturing and storing $\mathrm{CO}_{2}$ would significantly increase the operating costs. The Ministry of EZ therefore added a precondition:

"Because climate change is a global problem, the same conditions will have to apply to neighbouring countries." 132

Again, underlying this consideration was the imaginary of the Netherlands as an open, 'networked' energy economy.

In sum, ambitious $\mathrm{CO}_{2}$ targets and visions of $\mathrm{CO}_{2}$ roundabouts helped to mobilize commercial parties. However, being dependent upon voluntary agreements also made for a vulnerable arrangement. In the experience of several interviewees, energy companies and carbon-intensive industry use a multi-level lobbying strategy: in the Dutch context, they emphasize that the EU-ETS should govern commercialization of CCS, but in Brussels they lobby for a low $\mathrm{CO}_{2}$ price. ${ }^{133}$ When demonstration projects were proposed around 2009, it had become clear that emitting $\mathrm{CO}_{2}$ would (until at least 2020) be cheaper than applying CCS. Following the economic crisis, the price of $\mathrm{CO}_{2}$ plummeted from $€ 25 /$ ton in 2008 to $€ 20 /$ ton in 2011 and less than $€ 5 /$ ton in $2013 .{ }^{134}$ In turn, implementation of CCS came to a virtual standstill in the Netherlands. GDF SUEZ and E.ON long postponed their Final Investment Decision on offshore CCS. As a reason, they stated that "low $\mathrm{CO}_{2}$ price levels gave insufficient economic incentives to investments in capital intensive low-carbon technologies like CCS." ${ }^{135}$ In 2015, their new power plants came online unabated.

\footnotetext{
${ }^{131}$ Source: EZ. (2005). Nu voor later-Energierapport 2005. Ministry of Economic Affairs, p.10.

132 Ibid., p. 27.

${ }^{133}$ Obviously, energy-intensive companies operating in the Netherlands are not the only ones lobbying the EUETS dossier. Governments of member states relying on coal for electricity production (or having limited $\mathrm{CO}_{2}$ storage capacity) typically oppose political reform of the EU-ETS which would result in a higher $\mathrm{CO}_{2}$ price.

${ }^{134} \mathrm{RCI}$ studies indicated that CCS would cost around $€ 24 /$ ton $\mathrm{CO}_{2}$ in Rotterdam. Prior to the commercial stage (initially expected to start after 2012), enhanced recovery was meant to result in a revenue stream of $€ 32$ to 58/ton and to make CCS economically viable in case the EU-ETS and public funding provided insufficient economic incentives for commercial parties to invest. Source: RCI. (2007). $\mathrm{CO}_{2}$-afvang en opslag in Rijnmond. Rotterdam Climate Initiative, p. 9.

135 See: ROAD. (2013). The ROAD Project Experiences and Rotterdam Cluster Development Update. Rotterdam: Presentation by Hans Schoenmakers (Program Manager ROAD) at the 7th European CCS Conference.
} 


\subsection{CONCLUSION}

This chapter has explored the imagined relation between societal and technological progress which has inspired visions of CCS in the Netherlands. I have sketched how an energy imaginary of a 'networked nation' took shape from roughly the 1980s onwards, against the background of an ever more liberalized and European energy market. CCS was portrayed as a way to (again) capitalize on the Dutch position as a transit place for fossil flows and gas streams. Expectations on large-scale CCS allowed for stringent $\mathrm{CO}_{2}$ reduction targets in the Netherlands. At the same time, they helped to legitimize the construction of new coal-fired power plants. In turn, CCS became a necessity. I would claim that the imaginary of a 'networked nation' also helps to understand the slowness of CCS implementation. Most societal groups agreed that CCS should be implemented in the Netherlands. At the same time, it was acknowledged that the investment decisions of individual companies would (and should) be guided by developments at the EU level. Put differently, societal groups voluntarily subscribed to collective visions of large-scale CCS. However, the realization of this vision was curtailed by market-based considerations of commercial parties.

In his book The Politics of Climate Change, Anthony Giddens (2009) argues that global warming calls for an 'ensuring state': "As far as climate change is concerned, the state has to act as a facilitator, an enabler (...). Yet it can't be only an enabling body, since it has to ensure that definite outcomes are achieved - most notably a progressive reduction in carbon emissions. An ensuring state is one that has the capacity to produce definite outcomes, upon which not only can its own citizens rely, but so too can the leaders of other states" (2009, p. 8). In context of the EU-ETS and liberalization of the European energy market, it is unclear whether and how national governments can ensure that the production of $\mathrm{CO}_{2}$ emissions (stemming from fossil usage) is reduced within their borders. ${ }^{136}$ This is visible when looking at the collective Energy Agreements negotiated between the Dutch government, labour unions, industry representatives and environmental NGOs. The Agreement of 2013 depicts application of CCS (and the closure of three older coal-fired power plants) as 'necessary' for realizing sustainable energy reform. At the same time, it remains unclear how timely implementation of CCS can be ensured. The Agreement merely states:

"To realize a fully sustainable energy supply in the long term, CCS will be inevitable. CCS can be applied to industry and to gas- and coal-fired power plants. The

\footnotetext{
${ }^{136}$ At the time of writing, it is too early to tell what effect the court ruling (Urgenda Foundation vs the Dutch State, C/09/456689/HAZA13-1396) will have on the Dutch energy policies.
} 
national government will take the initiative to formulate a long-term vision of the role in CCS in the transition towards a fully sustainable energy supply." 137

So again, a collective vision is presented as crucial for inspiring (and governing) CCS implementation in the Netherlands. At the same time, the realization of this vision cannot simply be mandated, as this would negatively affect the competitive position of commercial parties operating under the EU-ETS and thereby of the Dutch 'energy economy' as a whole.

The energy imaginary sketched in this chapter is not static or pre-given. It developed over time, in response to changing views about climate change and fossil fuel scarcity. It drew upon local geological conditions (i.e. the presence of gas reservoirs suitable for $\mathrm{CO}_{2}$ storage) and on existing infrastructures and expertise (i.e. regarding gas extraction and distribution). The Dutch energy imaginary also provided an incentive for the development of new infrastructures (i.e. the EU-ETS, which the Dutch government has actively supported). In that sense, the notion of an 'energy imaginary' helps to explore the coproduction of techno-scientific and socio-political order. The reader may have noticed that I paid relatively little attention to changes in the Dutch government or to the outcome of national elections, even though these had important implications for the way that energy reform was pursued in particular periods. When suggesting that a Dutch energy imaginary took shape over time, I claim that there are cultural features and practices which have come to 'transcend' such political contingencies. Think of the culturally embedded and partly institutionalized emphasis on deliberation and participation. At the heart of an influential knowledge practice like back-casting is the idea that no single party can (or should be able to) wilfully redesign the national energy future. Obviously, these cultural features do not transcend day-to-day politics in an absolute sense. This is arguably the downside of the concept of socio-technical imaginaries. It obscures moments of change and intervention, e.g. when a particular group of actors decided that new coal-fired power plants were needed in the Netherlands. ${ }^{138}$.

To understand the decision-making process for concrete CCS projects, a different analytical perspective is needed. I will develop this in the next chapter, focusing on a project which seemed safe to most CCS experts but which became controversial nonetheless.

\footnotetext{
${ }^{137}$ Source: SER (2013). 'Energieakkoord voor duurzame groei', Sociaal Economische Raad, p. 98. More on the challenges involved in governing commercial-scale application of CCS in Chapter 4.

${ }^{138}$ For the reconstruction of such an influential moment, see: Heilbron, B., Mommers, J., Muntz, T., \& De Zeeuw, H. (2013). Nog een eeuw fossiel : Land van gas en kolen (Onderzoeksdossier). De Groene Amsterdammer, 136(4), 22-33. Regarding the Dutch energy imaginary of a networked nation, the introduction of a domestic natural gas infrastructure and the EU-ETS can arguably be seen as 'constitutional moments'.
} 

Framing safety and the politics of expertise 
Two issues are routinely put together in discussions on the future of CCS. Public acceptance is crucial for large-scale implementation. And demonstrating safety is a precondition for gaining public acceptance. As the International Energy Agency put it in one of its reports:

"The single most important hurdle which CCS must overcome is public acceptance of storing $\mathrm{CO}_{2}$ underground. Unless it can be proven that $\mathrm{CO}_{2}$ can be permanently and safely stored over the long term, the option will be untenable, whatever its additional benefits." 139

Or, as Rien Herber (Professor in Geo-Energy working on the implementation of CCS in Northern Netherlands) put it in 2009:

"Citizens just want to know whether it [CCS] is safe, that there will be no leakage for example. It is the task of science to answer these questions." 140

This suggests a 'classic' division of labour between science and politics, where experts establish the risks involved in a CCS project and communicate their findings to political decision-makers and the affected public. In general, experts from the international CCS community are confident that $\mathrm{CO}_{2}$ can safely be stored in the deep underground. Depleted gas fields are considered particularly well-suited, as they have contained natural gas for millions of years and reservoir properties are known from the extraction phase (see also Section 1.1). However, even in such projects, it can be far from straight-forward for actors to demonstrate safety and gain public acceptance.

This chapter will examine the controversy which surrounded the main onshore CCS demonstration project in the Netherlands (2006-2010). Experts were convinced that $\mathrm{CO}_{2}$ could safely be stored underneath the Dutch town of Barendrecht. Engineers claimed to have an intimate understanding of the designated gas fields. They stressed that the technologies for transporting and injecting $\mathrm{CO}_{2}$ had already been proven to work and that a combination of risk assessment and risk management could be used to guarantee safety. But some critics disagreed and stressed the uncertainties involved. Over a period of years, heated exchanges took place between experts, politicians and members of the public. More and more safety studies were conducted and 'Barendrecht' turned into an object of national debate. Ultimately, the project was cancelled in November 2010. Time delays and lack of public acceptance were cited as official reasons. $\mathrm{No} \mathrm{CO}_{2}$ had been stored and the issue of 'safety' remained unsettled. This cancellation has signalled the end of onshore $\mathrm{CO}_{2}$ storage in the Netherlands until the present day.

\footnotetext{
${ }^{139}$ IEA. (2004). Prospects for $\mathrm{CO}_{2}$ capture and storage, International Energy Agency, p. 20.

${ }^{140}$ December 2009, http://www.kennislink.nl/publicaties/rug-gaat-de-grond-in. Archived under: http://www.webcitation.org/6SG77sM8h.
} 
Guiding questions in this chapter are: How did actors try to come to an authoritative verdict on safety of the Barendrecht project? And why was this so difficult to achieve? To answer these questions, I will use a perspective on frames and overflows. This helps to see that the roles of 'expert', 'politicians' and 'member of the public' were not static or pre-given. Rather, they were constructed and contested. The perspective also makes clear that actors tried to supplement the 'classic' risk governance approach (with its strict division between certified safety experts and lay people) in subtle, reflexive ways. In the conclusion, I will suggest why such attempts failed to settle the Barendrecht controversy and will discuss relevant insights for understanding the slowness of CCS implementation more broadly.

\subsection{FRAMES, OVERFLOWS AND HYBRID FORUMS}

Sociologist Erving Goffman (1974) used the concept of 'frames' to describe the dynamics of interpersonal relations. What is a frame? It refers to a cultural space within which interactions can take place, more or less independently of the surrounding context (Callon, 1998, p. 249). ${ }^{141}$ Within a frame, actors with different forms of knowledge and different behavioural strategies are brought together. Assembled actors are capable of agreeing, often implicitly, on the frame within which their interactions take place and on the courses of action open to them. ${ }^{142}$ In the spirit of Actor-Network Theory, one may add that framing does not depend on the enrolment of human actors alone: frames involve physical and organizational devices too. Think of a theatre play. As a frame, it brings together backstage technicians, onstage players, audience members, seats facing the stage, limelight, et cetera. A theatre play comes with implicit rules and common signifiers (lifting the curtain means 'ssst!'). Only when all assembled actors play their part, the performance is convincing and the outside world temporarily forgotten. Other forms of daily interaction can be understood as frames too, like attending an academic lecture, queuing for the bus or doing gro-

\footnotetext{
${ }^{141}$ Where Goffman and Callon understand 'frames' in a dramaturgical sense, scholars in the fields of policy analysis, social movements and media studies have interpreted frames more as linguistic devices (e.g. Schön \& Rein, 1994; Nylander, 2001; Nisbet, 2009; Huttunen \& Hildén, 2014). All strands of literature have in common that particular frames can become institutionalized (or embedded in specific technological arrangements (Zwartkruis, 2013)), thereby structuring interactions and influencing actors' preferences, interests and beliefs. By adopting the dramaturgical perspective, I want to draw attention to the knowledge/power relations involved: within a frame, particular actors are legitimized to speak and particular forms of knowledge are considered more relevant than others.

${ }^{142}$ In that sense, 'frames' are introduced to overcome the structure-agency problem in sociology. Frames structure interactions, but only as long as the actors involved play their designated roles.
} 
ceries. All such situations are governed by specific rules and expectations; they 'work' only as long as the human and non-human actors involved play their designated roles.

Frames work by mobilizing people and objects (each endowed with supposed autonomy) and reducing them to specific actors following a script (Callon, 1998, p. 39). In the frame of traffic, people are temporarily reduced to eligible drivers, passengers and pedestrians. In the EU Emission Trading Scheme, $\mathrm{CO}_{2}$ is performed as a commodity (Callon, 2009; MacKenzie, 2009). Stephen Hilgartner, Professor in Science \& Technology Studies, has used this dramaturgical perspective to argue that scientists gain epistemic authority by carefully managing their back-stage and front-stage performance (2000, 2004). In academic lectures for example, the research process is typically portrayed as smooth and logical, thus obscuring the moments of frustration, doubt, improvisation and tinkering that are part of 'doing science' too.

Following a dramaturgical perspective, 'technology demonstrations' can be understood as performances too (W. Smith, 2009). Goffman argued that a demonstration is typically meant to provide "an ideal running through of an activity for learning or evidential purposes" (1974, p. 68-9). This fits with the distinction that is historically made between experiments and demonstrations in techno-scientific development (Shapin \& Schaffer, 1985). Experiments carry with them the possibility of surprise; their outcome is partly uncertain. Learning is done when things develop in unforeseen ways. Experiments are therefore typically conducted in a controlled and private setting. Demonstrations on the other hand are typically staged as public performances. They are meant to let spectators see for themselves that the science or technology involved 'works' (W. Smith, 2009, p. 452). Put differently: "The work of being a good demonstrator is not a matter of finding out unknown things, but of arranging a convincing performance" (Collins \& Pinch, 2010, p. 63). We may thus interpret the Barendrecht project as an attempt to demonstrate the safety of $\mathrm{CO}_{2}$ transport and storage to a variety of publics. This meant that a number of human and non-human actors had to be enrolled, like safety studies, risk regulations, pipelines, technicians, industry representatives, politicians, citizens and $\mathrm{CO}_{2}$. Initiators of the Barendrecht demonstration project were convinced that it could be safely executed. The question then is: why was it so difficult to orchestrate a convincing performance?

To understand this, an additional concept is needed. ${ }^{143}$ Frames 'work' (that is: they help to achieve stability in social interactions) by putting the complexity of the outside world

\footnotetext{
${ }^{143}$ A similar point is made by Noortje Marres (2007). She argues that 'frames' are usually understood as relatively stable entities that are relied upon to set limits for unstable things and issues. Frames are credited with the ability to organize public engagement by prescribing which considerations are relevant when responding to an issue. In turn, she argues that the notion of 'frames' alone (especially when understood in a discursive sense) cannot account for the dynamics of public controversies on techno-scientific developments. For Marres, a pragmatists' account of public involvement is better suited for this, as it directs attention to those instances where the issues
} 
between brackets. Crucially though, frames rarely succeed in abolishing all links of the assembled actors. More often than not, there are 'externalities' or 'overflows. ${ }^{\text {'144 }}$ An example, adapted from Callon (1998), may help to illustrate this: imagine that A, B and C are agents negotiating a business case for the construction of a coal-fired power plant. In the course of their interactions, they express their interests and evaluate possible agreements. The decision they take has positive or negative consequences (what economists label 'externalities') for another set of agents X, Y and Z, for example because these can purchase electricity or because they are affected by the power plant's pollution. The interactions between $\mathrm{A}, \mathrm{B}$ and $\mathrm{C}$ take place within a particular frame: that of negotiating a viable business case (bringing together market surveys, coal futures, equity partners, grey suits, et cetera). X, Y and $\mathrm{Z}$ are not involved in these negotiations, either because they have no way of intervening or because they have no wish to do so. When the consequences on $\mathrm{X}, \mathrm{Y}$ and $\mathrm{Z}$ remain unaccounted for, they remain externalities. Overflows can then be defined as those externalities of a frame which cause a challenge to the frame and its related techno-scientific practices.

It is hard if not impossible to determine whether overflows occur because actors point to 'real' (yet unrepresented) consequences or because actors break away from their designated roles and start to represent new problems. ${ }^{145}$ Overflows occur when the assembled human and non-human actors fail to play their designated role. Or, put differently, when a frame fails to keep the outside world at bay. The example of the coal-fired power plant can again help to make this clear. A, B and C conceived of X as consumers that are only concerned about the price of electricity. However, X may turn out be environmental activists, willing to pay extra for 'clean' electricity or to legally challenge the power plant's permits. And regardless of the consequences for $\mathrm{X}, \mathrm{Y}$ or $\mathrm{Z}$, we could imagine that agent $\mathrm{B}$ initially

under consideration change. So, when either the necessity or the safety of CCS turns into 'an issue', publics do more than simply adopting a joined discursive frame. They start to build alternative attachments between humans and non-humans. I agree with Marres that a perspective on 'frames' alone is insufficient for understanding the dynamics of a public debate and that it is worth exploring how specific publics mobilize around specific issues. At the same time, institutionalized frames and procedures do matter, in the sense that they structure public controversies to a certain extent and suggest which issues and what knowledge should be taken into account in political decision-making. In this chapter, I will focus therefore on the dynamic relation between frames and overflows as actors tried to 'settle' the issue of safety.

${ }^{144}$ Michel Callon uses the word débordements in his French writings (Callon, Lascoumes, \& Barthe, 2001). This is translated as 'overflows' in the English version (Callon et al. 2009). I prefer to translate the term initially as 'externalities', because 'overflows' might give the impression that a frame exceeds its borders by itself, like a river overflowing its natural basin. This visualization can be misguiding for the present purpose. It is what is outside of the original frame, those elements that are not originally contained, those actors which were not enrolled, that may cause a challenge to the frame. Put differently: the problem is not that a frame contains too much, but that it often contains too little and fails to keep the outside world at bay.

${ }^{145}$ From an Actor-Network Theory perspective, these are two sides of the same coin (see also Latour, 2005). 
joined the contract negotiations as an eager investor, but then started to doubt the business case for coal due to shale gas extractions elsewhere in the country. Agent $\mathrm{C}$ might have been a process engineer. Originally enrolled for his expertise on the energy penalty involved in $\mathrm{CO}_{2}$ capture, he may later start to express concerns about the uncertain health effects of nitrosamine emissions too. ${ }^{146}$ The point is that all such changes put pressure on (and potentially overflow) the original frame of negotiating a viable business case. New actors need to be enrolled and new knowledge gathered to contain these externalities in a new and 'broader' framing.

As said, overflows can be defined as those externalities of a frame which cause a challenge to this frame. Importantly, externalities are rarely clear from the start. Think of the link between asbestos and cancer. When the practice of using asbestos in building material became controversial, uncertainties rather than clear-cut health consequences were first highlighted. This links to broader discussions about the role of knowledge and uncertainty in democratic decision-making on techno-scientific developments (e.g. Gezondheidsraad, 2008; WRR, 2009; Dijstelbloem \& Hagendijk, 2011). According to Callon et al. (2009), modern democracies are characterized by two great divides: (i) that between 'lay' people and 'experts,' entitled to determine scientific and technical facts and (ii) that between publics and their political representatives. These two divisions are crucial for making (i) authoritative and (ii) legitimate decisions on techno-scientific issues. But when such issues become controversial, the double divide is challenged. Think of the development of HIV/AIDS and related treatments, as studied by sociologist Steven Epstein (1995). It was marked by heated debates. Who counts as an expert on the emerging disease: patients or doctors? And who can act as a legitimate spokesperson for patients when communicating with regulatory agencies like the US Food and Drug Administration or with pharmaceutical companies? The two democratic divides were contested and re-negotiated as new knowledge on HIV/AIDS was produced. The same is visible in debates on the externalities of nuclear waste, genetic modification, electromagnetic fields and, as I intend to show here, underground $\mathrm{CO}_{2}$ storage.

When externalities of techno-scientific developments are identified, they may overflow the double democratic divide and thereby challenge institutionalized frames for decisionmaking. A typical response is to organize 'hybrid forums' (Rip, 2003). These are open cultural spaces for interaction (thus: frames too) which are specifically designed to accommodate both the changing identities of actors and the changing stakes of a techno-scientific

\footnotetext{
${ }^{146}$ This is not a farfetched example. The uncertain health risk of degraded amine components, a by-product of the post-combustion $\mathrm{CO}_{2}$ capture process, became a matter of concern in the CCS Test Centre at Mongstad. Evar and Shackley (2012) have explored in detail how this scientific uncertainty affected the decision-making process on this Norwegian CCS project.
} 
development. Examples of hybrid forums are consensus conferences, citizen juries and focus groups. All aim to contain or anticipate the externalities of techno-scientific developments, e.g. in nanotechnology or geo-engineering. According to Callon et al. (2009), hybrid forums have the potential to democratize democracy. Or in the words of Robert Hoppe, Professor of Policy and Knowledge, there is a "political necessity of hybrid forums to correct for the overflows / externalities of a basically contractual society" (2011, p. 351). In order to do so, hybrid forums have to strike a balance between increasing variety ('openingup') and productive convergence ('closing-down') of actors and issues in order to result in a portable product and usable outcome (Rip, 2003, p. 424; Stirling 2004; Kouw, 2012, pp. 157-198). Finding this balance is far from straight-forward though in case of CCS, as I intend to show in this case study of the Barendrecht controversy.

Let us now return to the central questions of this chapter: How did actors try to come to an authoritative verdict on safety in the Barendrecht case? And why was this so difficult to achieve? I will argue that a perspective on frames helps to highlight that specific divisions of labour solidified within an institutionalized frame: the Environmental Impact Assessment procedure and its associated norm-based approach for risk acceptance. Still, it cannot explain why there was an incentive to enrol new actors and conduct additional safety studies. This is where the concept of overflows is helpful. Overflows provide an incentive to broaden the scope of inquiry, to mobilize new forms of knowledge and to subtly change the roles of 'experts,' 'politicians' and 'public representatives.' I will show that, throughout the Barendrecht controversy, actors reflexively looked for (and struggled to find) an appropriate balance between opening-up and closing-down the cultural space for expert deliberations to inform decision-making on the CCS project.

\subsection{RESEARCH DESIGN}

My analysis is based on information gathered during semi-structured interviews with 26 people involved in the Barendrecht controversy (see Appendix A). Interviews took between 45 minutes and $2 \frac{1}{2} 2$ hours each. Three interviews were held via telephone. All others were conducted in person at a location decided by the interviewee. Insights gained from interviews were supplemented with a textual analysis of reports used in the decision-making process and transcripts of public meetings. ${ }^{147}$ Written sources covered the period between April 2007 (start of the national tender procedure for an onshore CCS demonstration

\footnotetext{
${ }^{147}$ Some of these documents are archived and publicly available at the Historische Vereniging Barendrecht (visited on 26 March 2013).
} 
project) and November 2010 (when the newly appointed Minister of EZ cancelled the Barendrecht project). I strived for data saturation, in the sense that I collected material and conducted interviews to the point where no new relevant information was gathered. Data was analyzed using an open coding scheme. Initial codes were drawn from the theoretical framework, e.g. 'role: expert,' 'uncertainty' and 'overflow.' These codes were adapted, merged and changed during the research process and occasionally new codes gave impetus to new lines of inquiry. For example, it became clear that some critics used a different criterion for trustworthy expertise: affinity with matters of public concern. This was then investigated in more detail in some of the interviews.

This is not the first study of the Barendrecht controversy. Readers interested in public engagement, outreach and risk communication may for example turn to the excellent report "What happened in Barendrecht?!" by researchers from ECN (Feenstra, Mikunda, \& Brunsting, 2010). My depiction of the controversy will place greater emphasis on the (contested) role of experts and techno-scientific evidence. To structure my narrative, I broadly distinguish between project advocates and project critics. Under this first rubric, I cluster those people that were of the opinion that enough was known about safety to proceed with the Barendrecht project. Under the second rubric, I cluster those who felt that not enough was known about safety (without wanting to suggest that they were unambiguous spokespersons for the affected publics). ${ }^{148}$

Importantly, Shell's demonstration project was not a single performance. Over a period of years, actors were brought together in various cultural spaces to discuss numerous issues, including safety. Appendix B provides a chronology of the controversy, indicating the main procedures, events and publications. To structure my narrative, I distinguish between three periods (which partly overlap in time). This distinction serves to highlight the subtle changes in relations between 'experts,' 'political decision-makers' and 'public representatives' when it comes to assessing safety. Section 3.4 of this chapter revolves around the Environmental Impact Assessment procedure and its overflows (I: December 2007 - April 2009). Section 3.5 focuses on the alternative frame for decision-making drafted by local politicians (II: June 2008 - June 2009). This gave rise to a hybrid forum: Knowledge Table sessions, in which subtly different experts were enrolled and new safety knowledge was

\footnotetext{
${ }^{148}$ I will not speculate on reasons why some people were more concerned about safety than others. Readers interested in this aspect may turn to academic studies on risk perceptions, trust and risk acceptance (Slovic, 1993; R. Kasperson et al., 2000; Vlek, 2004; Daamen et al., 2011; Terwel, Daamen, \& ter Mors, 2013). Studies in these fields has shown that a given risk tends to be seen as less acceptable if the (perceived) controllability of consequences is lower; if the nature of the consequences is unfamiliar and dreadful; if one is exposed to the risk involuntarily; if the benefits of the activity are less clear and smaller; if the effects are more acute and closer in space and time; if risk and benefits are unfairly distributed; and if the likely harm is intentional (Van der Sluijs \& Turkenburg, 2006).
} 
produced. Mid-2009, local and provincial politicians voted against the Barendrecht project. But by that time, decision-making power had formally shifted to the national level. Section 3.6 how national politicians and members of CATO (the national consortium of CCS researchers) tried to accommodate the criticism on safety studies and reflexively looked for ways to allow for authoritative decision-making after all (III: April 2009 - November 2010). Before discussing the dynamics of the Barendrecht controversy, let me set the stage.

\subsection{SETTING THE STAGE}

The Nederlandse Aardolie Maatschappij (NAM) and Royal Dutch Shell have long embraced CCS, as it may add resilience to their portfolio of fossil-based activities in a carbonconstrained world. ${ }^{149}$ Or, as Shell's Project manager on $\mathrm{CO}_{2}$ storage put it in a company magazine:

"Large-scale $\mathrm{CO}_{2}$ storage allows for prolonged use of the earth's fossil fuel reserves. ... The ultimate goal should not be to replace the enormous amount of fossil energy that we currently use by an even larger amount of renewable energy; the challenge will be to let global prosperity grow sustainably, so with persistently lesser energy regardless of its origin." 150

Following a small-scale CCS pilot project on the North Sea, the Dutch government made public funding available for an onshore demonstration project. NAM/Shell responded to this tender. Shell owns a refinery at Rotterdam Pernis, producing more than 5 Mton $\mathrm{CO}_{2} /$ year which can be captured at relatively low cost. NAM (itself owned by Shell for $50 \%$ ) owns several depleted gas fields which can be used for $\mathrm{CO}_{2}$ storage. Initially, the focus was on a field called 'De Lier,' located only $15 \mathrm{~km}$ from Pernis. Studies indicated that injected $\mathrm{CO}_{2}$ would not leak from this gas field. However, several wells penetrated the reservoir. These wells could not be accessed anymore, so it would be impossible to (at reasonable costs) install monitoring devices, check their conditions or install additional plugs. ${ }^{151}$ Following a precautionary reasoning, De Lier was dismissed as a $\mathrm{CO}_{2}$ storage location. Next, the gaze turned to Barendrecht.

Barendrecht is home to over 45,000 people and is located $18 \mathrm{~km}$ from Pernis. Situated roughly 2 kilometres below residential areas are two gas fields. When the Dutch govern-

\footnotetext{
${ }^{149}$ Speech by Dick Benschop, CEO of Royal Dutch Shell, at the $7^{\text {th }}$ National CCS Conference (2014) in Amsterdam.

${ }^{150}$ Shell Venster (2006). 'CO 2 gaat ondergronds', Shell Nederland BV, May/June 2006, p. 9.

${ }^{151}$ See (van Luijk, 2003; CATO, 2009, pp. 34-39).
} 
ment made $€ 30$ million available for an onshore CCS demonstration project in 2007, NAM/Shell submitted a proposal to inject $10 \mathrm{Mt}$ of $\mathrm{CO}_{2}$ underneath Barendrecht at a rate of $0.4 \mathrm{Mt} /$ year (see Figure 12 below). NAM is owned by Shell and ExxonMobile. Allegedly, the latter company did not want to host $\mathrm{CO}_{2}$ injection in the designated gas fields. So, a new venture was started which bought the gas fields from NAM: Shell $\mathrm{CO}_{2}$ storage NV. Some critics felt that such changes in ownership made it unclear which company was ultimately responsible for ensuring safety. For reasons of simplicity, I will speak of 'Shell' in the remainder of the text, referring broadly to the industrial parties which took the initiative for the Barendrecht demonstration project by replying to the tender of the Dutch government.

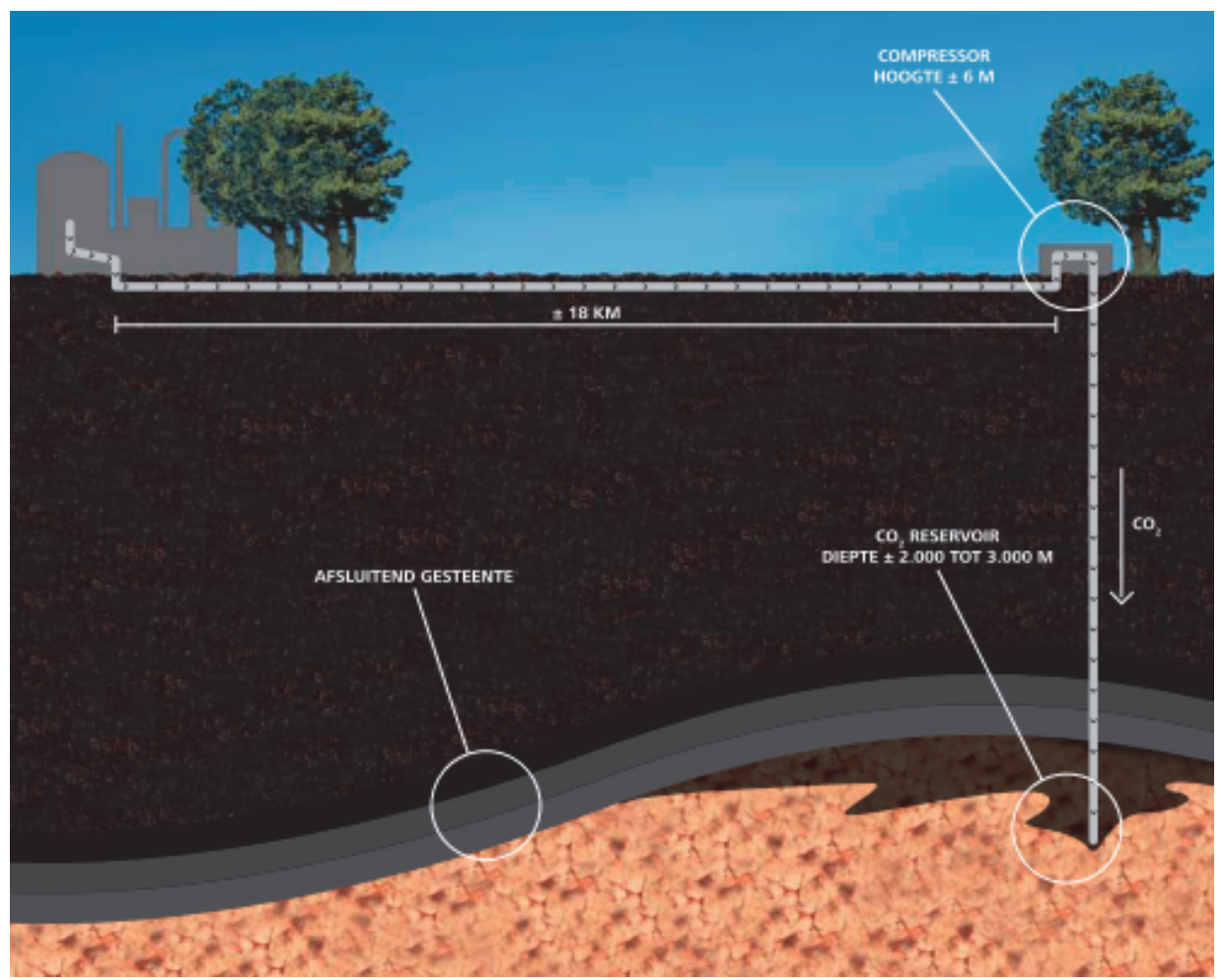

Figure 12: Schematic depiction the Barendrecht CCS project ${ }^{152}$

Raffinaderij, NAM \& OCAP.

152 Source: Shell (2007). Opslag van $\mathrm{CO}_{2}$ in lege aardgasvelden- Ondergrondse opslag bij Barendrecht, Shell Nederland. It is hard, if not impossible to 'set the stage' in a neutral manner. Any depiction of the underground, here in $2 \mathrm{D}$, is the result of numerous decisions and translations (see Latour, 1995). Some elements are represented, others are not. Figure 12 is for example not at scale, which gave some inhabitants the impression that CO 2 would be stored close to the surface. Furthermore, the figure depicts cap rock as a fluent, homogenous layer. Later in the controversy, Shell represented the underground differently. It for example circulated a 3D graph which involved 


\subsection{THE ENVIRONMENTAL IMPACT ASSESSMENT PROCEDURE}

By 2007, there was broad consensus amongst CCS professionals that enough practical experience had been gained to move to industrial-scale demonstration projects (Kuijper, 2011, p. 6228). Generic studies suggested that the risks involved could be mitigated via proper site selection and technical measures. ${ }^{153}$ In turn, an 'Environmental Impact Assessment' (in Dutch: MER) was seen as the appropriate way to provide political decisionmakers with factual input on safety of a specific project. The MER procedure consisted of several steps. In December 2007, Shell published an initial report which introduced the project and sketched the scope of the intended MER study. Members of the public and of an Advisory Committee MER (cie-MER) then had time to submit critical viewpoints. Taking these viewpoints into account, Shell published its final MER in December 2008. This report stated that legal norms regarding external safety were met. ${ }^{154}$ Again, critical viewpoints could be submitted. In April 2009, the cie-MER concluded that the MERBarendrecht had been adequately conducted.

Both the institutionalized division between expert judgment and political decisionmaking and the possibility to submit public comments are meant to give authority to the MER. The extent by which this 'opens-up' the frame is limited though. First, stakeholders may participate in knowledge production by submitting critical viewpoints, but the decision-making power ultimately remains in the hands of competent authorities (the municipal, provincial or national government). Second, the MER procedure only accommodates public comment on downstream risks relating to health, safety and the environment (Wynne, 2005). 'Soft' impacts on e.g. cultural values, labour relations or aesthetics fall outside of its scope (Swierstra \& Molder, 2012). So do broader issues like situational validation, systems vindication or ideological choices which play an important role in practical reasoning and the way that people come to an opinion about a project (F. Fischer, 2005). The MER procedure for example did not allow for a discussion on the use and necessity (in Dutch: nut en noodzaak) of CCS. It is illustrative that the cie-MER advised Shell to simply refer to international climate policies when responding to such comments. The MER itself

\footnotetext{
several other non-human actors, like faults, minerals surrounding the injection well and the Euromast of Rotterdam (to emphasize the relative depth at which underground CO2 storage would take place). My depiction of the controversy will focus less on the role of non-human actors, but will focus primarily on the changing roles of 'experts', 'politicians' and 'publics' in relation to the issue of safety.

${ }^{153}$ See also AMESCO. (2007). Generic environmental impact study on $\mathrm{CO}_{2}$ storage. Royal Haskoning, Ecofys, TNO, CE-Delft \& Golder.

${ }^{154}$ Shell. (2008). Samenvatting MER “Ondergrondse opslag van $\mathrm{CO}_{2}$ in Barendrecht." Shell $\mathrm{CO}_{2}$ storage BV, p. 34.
} 
should focus on one issue only: health, safety and environmental impacts of the Barendrecht project.

Before publishing its draft-MER in December 2007, Shell held informal meetings with the Executive Board of Barendrecht. Initially, local politicians did not strongly oppose to the project (Feenstra et al., 2010). This changed after public information sessions were held. In February 2008, Shell organized a first public meeting to inform inhabitants of Barendrecht. Roughly 60 people gathered in the local theatre, half of which had a professional interest in CCS. On stage were representatives of Shell and the Ministry of VROM. First, they sketched the official MER procedure and its openness to public comment. Second, the national climate policy was introduced, positioning CCS as a "necessary intermediate step in the transition towards a sustainable energy household." ${ }^{155}$ The Dutch government wanted to gain experience with the technology via small-scale demonstration projects: "Only then, we will know whether CCS can realize her promise." 156 Third, some technical details and characteristics of the local underground were sketched. Reference was made to Shell's experience in the oil and gas industry, to experiences with natural $\mathrm{CO}_{2}$ fields elsewhere in the world, to geological evidence (i.e. the fact that the Barendrecht fields had contained natural gas for millions of years) and to site-specific studies. These references were all meant to result in one simple message: " $\mathrm{CO}_{2}$ transport and storage is safe." 157

No doubt, this message was uncontroversial for the gathered CCS professionals. But others in the audience were worried. Present was for example Corrie Righolt-Dam, chairwomen of the local Christian Democrats (CDA-Barendrecht). Having obtained a doctoral degree in biochemistry at the University of Utrecht, she combined her political work with a part-time position as a lecturer in chemical technology at the Hogeschool Rotterdam. Righolt-Dam felt that the central focus of Dutch environmental policies on $\mathrm{CO}_{2}$ (as an important and allegedly harmful greenhouse gas) was 'dogmatic.' ${ }^{158}$ During the meeting in February 2008, Righolt-Dam raised several concerns. She criticized the analogy between natural gas and carbon dioxide, stressing that the two substances have different chemical properties. She also asked whether escaped $\mathrm{CO}_{2}$ could suffocate people. ${ }^{159}$ Representatives of NAM/Shell tried to ensure her (and others at the meeting) that $\mathrm{CO}_{2}$ is not a dangerous gas. Referring again to "roughly 50 years of experience" with resealing gas fields under high

\footnotetext{
${ }^{155}$ NAM \& VROM (2008). 'Ondergrondse opslag van $\mathrm{CO}_{2}$ in lege aardgasvelden: Ondergrondse opslag bij Barendrecht'. Presentation given during: Informatie Avond (5 February 2008, Barendrecht). See also Chapter 2. 156 Ibid. 157 Ibid.

${ }^{158}$ Interview CRD. See also: Vragen CDA-Fractie n.a.v. Startnotitie MER, February 11 2008, available at: http://www.cdabarendrecht.nl/co2-opslag-in-barendrecht/, archived under http://www.webcitation.org/63m8Haz4M).

${ }^{159}$ Gemeente Barendrecht (2008). Verslag informatieavond $\mathrm{CO}_{2}$-opslag in Barendrecht.
} 
pressure, they claimed that the only realistic way for $\mathrm{CO}_{2}$ to escape from the reservoir would be via the injection well. Given the well's concrete casing, the chance of this happening was estimated to be 'near-zero.' And since only a small amount of $\mathrm{CO}_{2}$ could leak anyway, this would immediately be dispersed by the wind. According to the experts on stage, there was therefore no realistic chance of suffocation. Righolt-Dam (considering herself an expert too) was infuriated by the feeling that her questions were arrogantly dismissed:

"They told a nice story: ' $\mathrm{CO}_{2}$ is a greenhouse gas. We are working to put in the underground so that it is no longer harmful.' But still, $\mathrm{CO}_{2}$ can be lethal if its percentage in the ambient air exceeds 5\%. And regarding this, it was said: 'This will not happen.' Look, I am a chemist, so I certainly do possess some knowledge on this matter. So I asked for background information. We just wanted to exchange views with these people, at an academic level. But when I asked to see the supporting literature, this was categorically denied. And this triggered suspicion." (interview CRD, Chair of CDA-Barendrecht)

Righolt-Dam's suspicions were not taken away. Over time, she became one of the most prolific critics of the Barendrecht project.

Other people had safety concerns too. Tessa Augustijn (chairwoman of GroenLinksBarendrecht) recalled for example that her mother had been present at the first information session and had returned home worried. For Augustijn, this was the beginning of a demanding and stressful period. Though lacking a technical education, she started reading the draft-MER and actively searched for information on the Internet. She for example stumbled upon the disastrous $\mathrm{CO}_{2}$ leakage from underneath Lake Nyos in Cameroon. ${ }^{160}$ Over time, her concerns only grew. In March 2009, she organized a protest march in which over 300 people participated. The core message: Shell's CCS project should not be sited in a residential area.

I have introduced these two figures in some length, because they adopted different strategies of critique. One was based on 'facts and figures,' the other on public protest. Of course, I do not mean to claim that all of Righolt-Dam's arguments were based on unambiguous facts. She notoriously claimed at a council meeting and in a national newspaper that 100,000 people in Barendrecht and neighbouring Rotterdam could die if all of the $\mathrm{CO}_{2}$ would suddenly escape. Few consider this to be a likely scenario. Nor is my aim to dismiss Augustijn's concerns about a rapid release of $\mathrm{CO}_{2}$ as mere fiction, in the way that

\footnotetext{
${ }^{160}$ See: http://en.wikipedia.org/wiki/Lake_Nyos. Note that administrators of this webpage engaged in numerous discussions about the causes and consequences of the disaster: http://en.wikipedia.org/w/index.php?title=Lake_Nyos\&offset=\&limit=500\&action=history. As a natural analogue, the $\mathrm{CO}_{2}$ release at Lake Nyos is used to increase scientific knowledge about geological $\mathrm{CO}_{2}$ storage too (Benson et al., 2002; Holloway, Pearce, Hards, Ohsumi, \& Gale, 2007).
} 
project advocates have done. ${ }^{161}$ Instead, I want to emphasize that both followed a different strategy to influence the decision-making process. And, the Municipal government adopted the former strategy. Barendrecht is hardly characterized by a protest culture. So, local politicians emphasized that a decision on whether or not to approve Shell's project should be based on 'facts and figures' alone. ${ }^{162}$

\subsubsection{Criticizing the MER, constructing overflows}

Local politicians criticized the outcome of the MER in various ways. They argued that there might be political bias. The MER procedure prescribes that experts gather behind closed doors and discuss how to interpret available studies, how to deal with remaining uncertainties and how to implement the critical viewpoints submitted on the draft-MER. Only afterwards, findings are communicated to the wider public and to political decisionmakers. This distinction between backstage and front-stage is meant to give authority to the MER. But someone like Righolt-Dam challenged it by presenting herself as a 'knowledgeable' (though excluded) spectator of the drafting of the MER. This critique was especially potent when combined with the suggestion that safety studies could be tainted by financial and political interests of those wanting to swiftly implement CCS. In turn, local politicians demanded to see the backstage. Initially, Shell dismissed this request because they felt that the normal procedure would ensure a more authoritative outcome:

"The Municipal governments ask for the technical reports by TNO. Project initiators have indicated that this information will be available together with publication of the MER. This is the usual procedure. As soon as the MER and all underlying reports are available, municipalities and other parties will have time to study these and reach a conclusion. Project initiators considered it unwise to publish the availa-

\footnotetext{
${ }^{161}$ See for example: "The Committee is convinced that a disaster like in Cameroon is unthinkable in case of the Barendrecht $\mathrm{CO}_{2}$ storage project" (Source: Cie-MER. (2009). Ondergrondse opslag van $\mathrm{CO}_{2}$ in Barendrecht: Toetsingsadvies over het milieueffectrapport (2047-172). Commissie MER, p.7).

162 The decision of GroenLinks to organize a protest march was seen by other local politicians as a grave 'faux-pas'. Augustijn was accused of pursuing personal/political gains by publicly opposing the project with her single-party initiative. For some months, GroenLinks-Barendrecht was banned from participating in Municipal meetings on the CCS dossier. One might interpret the emphasis on facts and figures as a strategic choice. An early 'no' would have made local politicians vulnerable to the accusation of being NIMBY's, especially in the period that the MER procedure was not finalized yet. Regardless, many critics made clear in interviews that they genuinely questioned the safety of Shell's project.
} 
ble 'raw' information earlier, at a time when it is still impossible to come to an all encompassing, well considered verdict." 163

Righolt-Dam disagreed and continued to publicly criticize the MER procedure for a lack of transparency. She for example did so during an interview in television program Buitenhof (focusing on political affairs). In response, Shell took an unusual decision: it shared the underlying technical reports before publication of the final MER.

But showing the backstage was not enough. Critics maintained that an independent scientific review was missing. Without this, the MER procedure could still be tainted by financial and political interests. The cie-MER is the institutionalized actor to prevent this from happening. The chair of the committee emphasized that its final verdict on the quality of the MER was 'non-political':

"It is relevant to note that the Advisory Committee MER does not give a political verdict (e.g.on whether something is safe enough), but investigates whether the given environmental information and environmental arguments are correct. The cieMER is put in place and is being subsidized by the Ministry, but operates completely independent and based on expertise. ... Minister Cramer of Environmental Affairs plays no role in the MER procedure."164

But according to critics, this provided insufficient assurance. Shell had based its safety claims mainly on practical experience with analogue industrial activities and on site-specific studies. Critics instead presented 'independence' and 'peer review' as whole marks of authoritative science. ${ }^{165}$ As Righolt-Dam put it:

"TNO was hired by Shell. There was nobody ... Shell is a major player, right, also in terms of financing. ... No knowledge institute is independent anymore. Someone in my direct environment also had an email conversation with the Chair of the CieMER. This also revealed so much ignorance [in Dutch: onkunde]. Really ... And also these were people with antennas and interests. This [cie-MER] was also not completely independent, because some of them had worked for Shell" (Interview CRD)

The suggestion was that the 'experts' of the cie-MER provided insufficient assurance that political and financial interests had been kept at bay in safety studies.

\footnotetext{
${ }^{163}$ Shell. (2008). Verslag van de informatieavond project $\mathrm{CO}_{2}$-opslag Barendrecht (16 april 2008). Shell $\mathrm{CO}_{2}$ Storage BV.

${ }^{164}$ Barendrecht. (2008). Notulen openbare vergadering commissie Ruimte (18 November 2008). Gemeente Barendrecht, p.3.

165 This could be understood as 'expulsion', a form of boundary work in which some aspects of good science are emphasized over others (Gieryn, 1999). Using their own yardsticks for authoritative science-for-policy, critics tried to dismiss the MER as an untrustworthy basis for political decision-making.
} 
Furthermore, critics argued that some relevant aspects (or: externalities) had been overlooked or remained unaccounted for. Questions were for example raised about the effect on local property values. This issue was not discussed in the MER and quickly turned into an overflow. And, as regulations prescribed, the MER had only assessed the risk of people dying from $\mathrm{CO}_{2}$ leakage. But critics argued that this frame was too narrow: non-lethal health effects should be considered too (i.e. when drafting an emergency response plan). To give another example: the EU Directive on CCS (2009) prescribes that a transfer of responsibility/liability from operator to national government may occur after sufficient trust is built that the injected amount of $\mathrm{CO}_{2}$ is safely stored. This trust is gained by collecting seismic data and monitoring the underground for a period of 10 to 50 years. But local politicians also wanted to know what would happen after this period. How could eternal monitoring and the proficiency of century-long risk management measures be guaranteed? Shell did not (have to) indicate this in its project proposal. According to some critics, consequences that could occur after 50 years time remained uncertain and thus constituted an overflow at the moment of decision-making.

\subsection{THE LOCAL TOETSKADER}

To contain overflows, local politicians drafted their own criteria for decision-making. The so-called 'Toetskader' consisted of a list of questions and risk-averse demands. Standards of evidence were added too, like:

"All of the technology used should have proven itself, in terms of reliability and safety, already in practice. The Municipality of Barendrecht and the direct surrounding should in no way suffer damages and / or be exposed to unacceptable risks caused by the $\mathrm{CO}_{2}$ project." 166

Obviously, such a demand begged the question of who gets to decide upon the acceptability of risk. In the Netherlands, legal norms are the institutionalized way to settle this political question. Place-bound risks are for example an expression of the chance/year that one person, who is permanently and unprotected present at a given location, will die from accidental exposure to a hazardous substance or activity. According to the legal norm, a chance below $10^{-6} /$ year is acceptable. ${ }^{167}$ But local politicians did not agree with this norm.

\footnotetext{
${ }^{166}$ Gemeente Barendrecht (2008). Toetskader $\mathrm{CO}_{2}$ opslag. Approved by the Municipal Government of Barendrecht on 15 December 2008, p.1.

${ }^{167}$ See Ale (2005) for the historical and political background of this aspect of the Dutch safety culture.
} 
Righolt-Dam for example argued in favour of a more stringent cut-off point, given the eternal character of underground $\mathrm{CO}_{2}$ storage:

"The risks that they gave were one in a million. After I had informed myself, I was of the opinion that at least $10^{-9}$ should be used instead of $10^{-6}$. So the risk should be a factor 1000 less, because calculations indicated that this still meant 5 fatalities in 1000 years time. Well, eternally, this would add up to a lot.” (Interview CRD, Chair of CDA-Barendrecht)

The implicit suggestion was that local politicians should be free to set their own criteria for decision-making, established rules and procedures notwithstanding.

\subsubsection{Enrolling 'critical' experts}

Local politicians insisted that they would base their decision on 'facts and figures' instead of mere public opinion. The Toetskader was meant to avoid that "the truth would become the first $\mathrm{CO}_{2}$-victim." ${ }^{168}$ Local politicians thus decided to consult experts to provide the requested knowledge and to answer the questions raised. Importantly, these were subtly different 'experts' than the ones originally enrolled in the MER frame. Under normal circumstances, local politicians would turn to the regional Environmental Protection Agency (DCMR) for advice. DCMR has an excellent reputation in the region of Rotterdam. As the former vice-president of the Agency put it, the epistemic authority of the DCMR is rarely questioned:

"As Alderman of Rotterdam, I was also vice-president of DCMR. At the time, I ensured that DCMR would not come to a judgement on Barendrecht in a rash manner. For this, the status of DCMR is simply too important ... DCMR is the absolute authority in terms of safety and environmental risk. It has this reputation. In principle, a judgement of DCMR is undisputed." (Interview MH, former wethouder Milieu, Economie en Haven, Rotterdam)

In the Barendrecht project though, DCMR had to play three roles simultaneously. First, it was meant to advise regional politicians on health, safety and environmental aspects. Second, the Agency was charged with enforcing environmental regulations and granting environmental permits on behalf of the Provincial government. Third, and more controversially, DCMR supported the regional development of CCS as a founding member of the Rotterdam Climate Initiative (see Section 2.7). ${ }^{169}$ DCMR employees had put in place an internal (and mostly informal) 'firewall' to prevent that the Agency's authority would be un-

\footnotetext{
${ }^{168}$ Gemeente Barendrecht (9 March 2009). 'Notulen Openbare Vergadering Commissie Ruimte', p.6.

${ }^{169}$ DCMR is a founding member of the Rotterdam Climate Initiative (see Chapter 2).
} 
dermined by role confusion. However, politicians in Barendrecht were unconvinced and felt that DCMR's experts were untrustworthy, because their employer had a political interest in advancing CCS. ${ }^{170}$ In turn, DCMR was asked to take on a fourth role: facilitator of the decision-making processes.

Arie Deelen (the eminent Head of DCMR's internal Expertise Centre) was seen as the ideal person to play this unconventional role, because he was sufficiently separated from the Agency's more 'political' work on permit applications and CCS development:

"Also in our internal organisation, there was a department working on permitting. I wasn't the Head of that department. At that time, I was the Head of the internal Centre of Expertise, which meant that I had the most free role and could thus join the conversation in the most neutral and independent manner. That's how we tried to separate the various roles, also within the organisation." (interview $\mathrm{AD}, \mathrm{DCMR}$ )

Arie Deelen invited politicians of the Municipality Barendrecht, the province SouthHolland and the national government to discuss administrative issues on a regular basis. Their 'Bestuurlijk Afstemmingsoverleg $\mathrm{CO}_{2}$ ' $\left(\mathrm{BCO}_{2}\right)$ was a procedural innovation (Feenstra et al., 2010). Participants reflexively looked for ways to frame the interactions between 'experts,' 'politicians' and 'the public,' so that an authoritative verdict on safety of the Barendrecht project could be made.

Initially, members of the $\mathrm{BCO}_{2}$ drafted a list of expert-advisors. As Arie Deelen recalled, the criterion was that they should have a "broad kind of expertise which could also be authoritative towards Barendrecht" (interview AD). However, the list was met with suspicion by local politicians. As the Municipality's Secretary recalled, they used a different criterion for authoritative expertise:

"When the Ministry and DCMR were like: 'just be advised by someone who can explain that all will be well', there started to emerge a counter movement. Like: we'll be advised by someone critical, because we have several serious questions. It was for example suggested that mister Turkenburg [Professor of Natural Sciences and Society at Utrecht University and one of the initiators of the national CCS research program CATO] could give an explanation. They were saying: 'He can tell a good story and will turn that room around in no-time.' But I was thinking: I am not here to look for someone who can convince an audience, I am looking for someone who can give a serious answer to our questions" (interview MV)

So, local politicians looked for 'critical' experts, meaning that they would take local concerns seriously. They had to be 'independent' too. Almost all people on the list had either worked for Shell or participated in the national research program CATO. They were there-

\footnotetext{
${ }^{170}$ VVD-Barendrecht and SGP-Barendrecht maintained that DCMR was in fact trustworthy. These parties wanted to be consulted in the regular way. However, the majority of local parties disagreed.
} 
fore dismissed. Experts with a clear interest in opposing CCS were officially dismissed too. Olaf Schuiling, an emeritus professor in geochemistry at Utrecht University who passionately advocated the use of olivine as a more viable climate mitigation measure, for example offered his advice to local politicians but was never officially consulted. ${ }^{171}$ Instead, Cees van den Akker (emeritus professor on hydrology at TU/Delft and former-director of RIVM) was hired for issues relating to the underground. Frank Candreva of Det Norske Veritas (an international company working on certification, verification and management of technological risk) was asked to have a critical look at $\mathrm{CO}_{2}$ transport and injection. ${ }^{172}$

\subsubsection{The Knowledge Table as a hybrid forum}

With critical experts selected, the question was how they could inform political decisionmaking. Participants of the $\mathrm{BCO}_{2}$ decided to organize so-called 'Knowledge Table sessions' in which a range of experts would critically discuss the available knowledge regarding, amongst others, safety. ${ }^{173} \mathrm{~A}$ distinction between backstage and front-stage was negotiated too. As Arie Deelen (DCMR) explained, participants should be free to discuss and demonstrate their uncertainties "in een zekere vertrouwelijkheid en openheid." It was thus decided to have closed expert meetings and to publish a joint summary report afterwards, which would indicate the areas of agreement and disagreement. The goal was not to take away all scientific uncertainties, as this could take forever. Rather, the Knowledge Table was meant to provide timely and authoritative input for political decision-making.

The role of the two 'critical' experts was contested. Margriet Kuijper (Shell's $\mathrm{CO}_{2}$ Project Manager) felt that especially Van den Akker lacked the necessary knowledge to partici-

\footnotetext{
${ }^{171}$ See also: http://www.pm.nl/artikel/221/olivijn-beste-oplossing-voor-CO ${ }_{2}$-problematiek.

Archived under: http://www.webcitation.org/6QOmRKpsS. Professor Olaf Schuiling was never officially consulted as an expert by politicians in Barendrecht, but some kept in touch with him informally. In October 2009, Schuiling was invited to participate as an expert in the Round Table Session organized by politicians of the province South-Holland.

${ }^{172}$ Some local politicians questioned whether the representative of DNV had been critical enough. As the Municipal Secretary put it: "DNV took a very moderate stance. It has a lot of contact with Shell and does not benefit from making bold statements. It is a professional organisation. ... That is also the hard part of the 'facts and figures' strategy: you easily end up in two camps. We weren't really looking for 'against', but much more for 'critical'. En that is a more nuanced stance, which can be difficult to come by. ... Lookin back, I think that we expected a more critical stance from DNV en a slightly less extreme one from Van den Akker" (Interview MV). Some local politicians even started to question the authority of Van den Akker, because he was being too critical. Nevertheless, Van den Akker's arguments (more than Candreva's) informed the critical viewpoint which local politicians unanimously adopted in response to Shell's MER. This chapter therefore focuses mostly on the actions and arguments of Van den Akker.

${ }^{173}$ Other issues were e.g. site selection and monitoring. I will only focus on (external) safety here.
} 
pate in expert discussions. Arie Deelen (DCMR's process manager) disagreed. He emphasized that the professor's role was not to contribute directly to the production of new knowledge, but to critically reflect upon the work of others:

"They [the experts consulted by Barendrecht] have a generic sort of expertise, a generic sort of scientific experience, by which they can, without knowing all the ins and outs of the technology... They should be able, and there I disagree with Kuijper, to understand the explanation of an expert. And then they should be able to challenge that explanation." (interview AD)

Looking back on his experiences, Van den Akker felt that he indeed could draw on his general knowledge as a civil engineer and his experiences with environmental protection as a former employee of the RIVM. Often though, topics had fallen beyond this professional expertise. In those cases, he had tried to play a hybrid role:

"I promised that I would join the sessions, as if I was an inhabitant of Barendrecht. I would bring my expertise. But in case this falls short, I am just an inhabitant and ask: 'How does this feel?' That was my approach. ... I was in-between. On the one hand, I felt that I understood reasonably well what those technical guys known, because I also know how to construct a well. Perhaps not one for the deep underground, but still... And I know something about the structure of the underground, so I could understand that reasonably well without being a pure specialist myself. On the other hand, I also had an understanding of the local concerns. I tried to fill the space in-between." (Interview CvdA)

As an emeritus Professor in Hydrology, Van den Akker lacked certified expertise on the deep underground. However, he claimed to fill the metaphorical space between 'experts' and 'the affected public.' On the one hand, he stressed that he had more knowledge than an average inhabitant of Barendrecht, which legitimized his presence at the Knowledge Table. On the other hand, he tried to show more affinity with local concerns than other participants, which legitimized his role as a 'critical expert' for Barendrecht.

\subsubsection{Containing overflows through focused inquiry and peer review}

As a hybrid forum, the Knowledge Table was meant to contain the overflows of the MER. Participants were asked to critically look at the conducted safety studies. They did so in several ways. First, differences between the MER's depiction of reality and actual conditions in and underneath Barendrecht were explored. It was for example noted that the computer models used to calculate the risk of leakage had failed to take into account that $\mathrm{CO}_{2}$ pipe- 
lines would partly run through a tunnel. ${ }^{174}$ This meant that both the chance of a pipeline rupture ('failure rate') and the associated consequences should be reassessed. And it was noted that risk calculations had only focused on the effect of $\mathrm{CO}_{2}$ leakage on humans. However, non-human actors could be affected too. Experts from the Safety Region Rotterdam (VRR) asked whether it was known how fire trucks and other emergency response vehicles would behave when driving through a cloud of $\mathrm{CO}_{2} \cdot{ }^{175}$ After investigation, Shell concluded that internal combustion engines are only jeopardized if atmospheric $\mathrm{CO}_{2}$ concentrations exceed 10 to $20 \%$, a situation which was not expected to happen. In sum, participants pointed to differences between the conditions assumed in the MER study and actual conditions in the local context. This resulted in new lines of inquiry and helped to contain some overflows.

Second, participants used expert peer review to assess whether the MER had properly dealt with known epistemic uncertainties. Let me give an example. Probit functions are used in risk analyses to calculate the percentage of fatalities if humans are exposed to different concentrations of a substance for different periods of time. These functions are based on animal experiments, which are mathematically translated to provide a measure of human inhalation toxicity. Already in 2007 though, RIVM had issued a communication on the probit function for $\mathrm{CO}_{2}$. Experiments suggested that exposure to high $\mathrm{CO}_{2}$ concentrations caused an uncommon 'all or nothing' effect. RIVM therefore warned that it might be impossible to deduce a reliable probit function for $\mathrm{CO}_{2}$ until further experiments would be done. The authors of the MER had been aware of this epistemic uncertainty and had dealt with it by using conservative assumptions: $1 \%$ of people will die if exposed for 30 minutes to an atmospheric concentration of $5 \%$ of $\mathrm{CO}_{2}$ and $100 \%$ will die if exposed to a concentration of $10 \%$. At the Knowledge Table, it was discussed whether these assumptions were conservative enough. As a form of quality control, external experts from RIVM were consulted. They replied that it was at that time "still debated whether using a probit function for $\mathrm{CO}_{2}$ was at all viable," but added that the probit function used in the MER was more conservative than the one provisionally suggested by RIVM in $2007 .{ }^{176}$ Participants of the Knowledge Table therefore concluded that the MER had used assumptions which were sufficiently conservative. Although the exact probit function for $\mathrm{CO}_{2}$ remained unknown, this uncertainty did not undermine the trustworthiness of the MER.

\footnotetext{
${ }^{174}$ DCMR (2009). Kennistafel $\mathrm{CO}_{2}$-opslag Barendrecht, Einddocument. April 2009, p. 9.

${ }^{175}$ Ibid., p. 64.

${ }^{176}$ Ibid., p. 47.
} 


\subsubsection{Ignorance and the 'paper reality' of safety studies}

Van den Akker agreed that focused inquiry and peer review helped to contain some overflows of the MER. He nonetheless remained critical. When advising the Municipal government, Van den Akker did more than acting as a neutral 'broker' of (non-)knowledge. He took a clear stance: $\mathrm{CO}_{2}$ should not be injected underneath Barendrecht. The Professor in Hydrology considered CCS to be an outdated practice, reminiscent of waste management in the 1960s and 1970s. In those days, hazardous substances were still routinely injected in the underground for future generations to solve. Although $\mathrm{CO}_{2}$ is less hazardous than other chemical substances, inhabitants would still be exposed to risk. Van den Akker judged this risk to be very small, but it was unpleasant nonetheless. He felt that introducing it was unacceptable, because the risk was (in his view) not offset by clear benefits to the local community. According to Van den Akker, the Barendrecht project only served the economic interests of Shell and the careers of national politicians. Importantly, these opinions did not match with his role as a 'critical expert' on the underground. So during Knowledge Table sessions, Van den Akker argued instead that Shell's project involved uncertain and potentially harmful consequences.

First, Van den Akker pointed to a tension in risk communication. Shell would receive nearly $€ 30$ million in public subsidies for the Barendrecht project. This was legitimized by pointing out that a lot still had to be learned about CCS. In the first paragraph of its Startnotitie MER, Shell stated for example:

"Although many studies have been done [on storing $\mathrm{CO}_{2}$ in depleted gas fields], there is still little practical experience with this." ${ }^{177}$

But in its safety communications, Shell qualified CCS as a 'known practice.' According to project advocates, this did not mean that there were no uncertainties or that all risks could be calculated in a deterministic fashion. Instead, they insisted that ignorance (caused by a lack of practical experience) would not have harmful consequences because operators could take technical prevention measures which were known from related industrial practices, like

\footnotetext{
177 Shell. (2007). Startnotitie milieu-effectrapportage: Ondergrondse opslag van $\mathrm{CO}_{2}$ in Barendrecht. NAM \& Shell, p. 5. Shell emphasized in its final MER of December 2008 that there was actually enough experience to ensure safety of underground $\mathrm{CO}_{2}$ storage, making reference to the small-scale K12-B project on the Dutch North Sea and the larger Sleipner project in Norway: "There is, both in the Netherlands and elsewhere in the world, already sufficient knowledge and experience to technically realize and safely execute storage projects". Source: Shell. (2008). Samenvatting MER “Ondergrondse opslag van $\mathrm{CO}_{2}$ in Barendrecht." Shell $\mathrm{CO}_{2}$ storage BV, p. 6.
} 
underground gas storage. ${ }^{178}$ In turn, Shell claimed that its demonstration project would mostly yield non-technical lessons:

"The use of known technologies does not mean that there are no uncertainties: none of the identified uncertainties will however lead to an unacceptable risk. We foresee that the main uncertainties and learning effects will relate to the non-technical aspect of the project, like judicial issues, public acceptance, emission credits and communication." 179

Van den Akker challenged this ordering though. For him, the lack of practical experience with CCS meant that there remained 'technical' uncertainties too:

"When I read the main report, like a partial expert, I noticed that it stated on so many occasions: 'It is safe'. Virtually on every page... My reasoning was: 'If it does not qualify as standing technology, there is uncertainty. And if there is uncertainty, there are safety risks.' So I understand that Shell is saying: 'We have a lot of experience, we can do this. For us, this is standing technology'. But then you contradict yourself, because you also claim that you want to do this demonstration project because you still want to learn" (Interview CvdA, italics added)

To turn uncertain consequences into overflows, Van den Akker referred to collective experiences with another activity in the deep underground: natural gas extraction in NorthernNetherlands. This was presented as evidence that uncertain geological processes could have harmful consequences despite state-of-the-art calculations:

"Project initiators went to great lengths (in terms of research and model simulations) that show that $\mathrm{CO}_{2}$ storage really is safe... We want to warn against relying too much on models. On this point, experts of Barendrecht have pointed to experiences with natural gas extraction in Northern-Netherlands. At the time, the negative effects that now have occurred were not indicated by model-based calculations"180

\footnotetext{
178 Think of compartmentalizing the $\mathrm{CO}_{2}$ pipeline, installing a blow-out prevention system or creating a safety margin by quitting injection when the gas field was still a few bars below its original pressure. Van den Akker questioned the effectiveness of such safety measures. He argued for example that the pressure difference would be levelled-out over time, thus making the 'safety margin' ineffective in the long run. Needless to say, this was a contested statement. Project advocates argued that several other trapping mechanisms would help to keep the injected $\mathrm{CO}_{2}$ securely in place.

${ }^{179}$ Source: Shell. (2008). Plan van aanpak Barendrecht $\mathrm{CO}_{2}$-opslag project. Royal Dutch Shell, p. 49. This style of reasoning is not neutral: "To declare that an issue is technical is efficiently to remove it from the influence of public debate; on the other hand, to recognize its social dimension restores its change of being discussed in political arenas" (Callon et al., 2009, p. 25).

${ }^{180}$ DCMR. (2009). Kennistafel $\mathrm{CO}_{2}$-opslag Barendrecht-einddocument. Expertisecentrum, p. 19. Compare: "This type of model-based calculations, going beyond a couple of years, are by definition unreliable because we don't have that experience. The underground is terribly complex. You can make a simplified model and say: 'we know it
} 
Via this analogy, the trustworthiness of safety studies was fundamentally challenged. ${ }^{181}$ Van den Akker warned that the MER only constituted a 'paper reality.' As the Secretary of Barendrecht recalled, this argument was picked up by local politicians:

"Of course, that was the responsibility that the Municipal government started to feel towards its population: if we are claim that it is safe, we really must be sure that it is. And Van den Akker indicated to us: 'Do realise, it [the MER] is a paper reality. It is all available knowledge combined; there is no hidden agenda behind it. But it is limited. You can, like in Groningen, claim at a certain moment that the underground will not move, based on the brightest minds and the most advanced analyses, but it can still happen'." (Interview MV)

In other words, some local politicians felt that ignorance undermined the authority of even the best safety studies. A similar reasoning was followed for other overflows, like the possible effect of Shell's project on local property values. In January 2009, local politicians commissioned a study on this issue. Four months later, an advisory bureau found that no economic damage had yet been done. However, the study also stressed that declining property values could not be predicted due to possible "temporary psychological effects" in the future, caused by e.g. public safety concerns. ${ }^{182}$ Thus, this new study only reiterated that Shell's project entailed uncertain (and for some: unacceptable) consequences. ${ }^{183}$

One should note that, at this point in the controversy, it had become difficult to separate 'facts and figures on safety' from 'public safety concerns.' Let me illustrate this with an example. Referring to her knowledge of chemistry, Righolt-Dam had claimed that a sudden release of all injected $\mathrm{CO}_{2}$ could suffocate over 100,000 people in the region. In retrospect, she acknowledged that this claim had made some people worried:

"I did not delete it from our website, because it is a piece of history. In hindsight, I think: if it makes people scared, you should formulate it differently. Obviously,

\footnotetext{
so well and we will do this and we will make a calculation', but you simply do not know for sure" (interview CvdA, professor Hydrology and consultant for the Municipal government of Barendrecht).

${ }^{181}$ Analogies arguably tell us about the potential impact of reducible ignorance. It seems much more difficult, if not impossible, to turn irreducible ignorance into an overflow. Since this form of uncertainty can by definition not be accounted for in decision-making, pointing to it has little critical thrust.

182 SAOZ. (2009). Risicoanalyse (plan)schade met betrekking tot het project "Ondergrondse $\mathrm{CO}_{2}$ opslag" in de gemeente Barendrecht. Stichting Adviesbureau Onroerende Zaken, May 2009.

${ }^{183}$ This overflow was later picked-up in the scientific sphere too. Numerous studies have been done on whether/how compensation may help to overcome local opposition (e.g. Wade \& Greenberg, 2011; Mors, Terwel, \& Daamen, 2012; Terwel, Koudenburg, \& Mors, 2014). Such studies emphasize the importance of fairness and timing in offering compensation. For the Barendrecht project though, these insights came too late. When representatives of the national government cautiously and informally mentioned the possibility of compensation Mid2009 , local politicians (convinced that safety could not be guaranteed) dismissed it as an unacceptable form of bribery.
} 
what can theoretically occur does not have to occur. It is about risk and for a lot of people, this is hard to understand. But we had trouble activating Rotterdam-Zuid. Perhaps the way that we published this involved emotions, but we had to trigger people" (interview CRD, chairman of CDA-Barendrecht).

The crude calculation thus served a double purpose. As a hyperbole, it illustrated that Shell's project could have harmful consequences. More controversially, the calculation also served to mobilize a concerned public. ${ }^{184}$ For this reason, the chairman of VVDBarendrecht considered it a form of demagogue politics. He was personally convinced that Shell's project was safe and urged his fellow politicians not to engage in 'scaremongering. ${ }^{185}$ Nevertheless, he recognized that public safety concerns had become a very real consequence in Barendrecht. In June 2009, local politicians unanimously voted against Shell's project because they felt that (i) safety could not be guaranteed and (ii) there were public safety concerns. A few months later, provincial politicians did the same. This was hardly the end of the risk controversy though.

\subsection{SHIFTING TO THE NATIONAL LEVEL}

In April 2009, the 'Rijkscoördinatie-regeling' had become effective. It shifted decisionmaking power on energy projects of national interest from the municipal to the national level. In June 2009, the responsible Ministers of Economic Affairs (EZ) and Environmental Affairs (VROM) visited Barendrecht. They stressed that political decision-making should be based on facts instead of emotions. It was difficult for local politicians to directly challenge this rhetorical divide, if only because many critics had indeed been emotional when expressing their concerns. So, they instead questioned the relevance of the distinction. ${ }^{186}$ The MER had only assessed the risk of people dying from $\mathrm{CO}_{2}$ leakage. But critics argued that this frame was too narrow: psychosomatic consequences could occur as well. It was

\footnotetext{
${ }^{184}$ See also Feenstra, Mikunda \& Brunsting (2010, p. 17).

${ }^{185}$ Whether the appeal to emotions is objectionable arguably depends on one's understanding of democracy. A Deweyian interpretation suggests for example that an issue (e.g. safety of underground $\mathrm{CO}_{2}$ storage or global warming) may spark a group of engaged actors (thus: a public) into being. But this 'sparking' does not occur by itself (Marres, 2007). It requires a considerable amount of work. As Mark Brown notes: "All activities with indirect consequences create a protopublic, and simultaneously, a need for representatives to transform the protopublic into a self-conscious public, aware of itself and capable of responding intelligently to conditions that affect it" (M. Brown, 2009, p. 142).

${ }^{186}$ See also the work of philosopher Sabine Roeser (2011) on the relevance of emotions for making informed judgments about risk situations. Obviously, her plea is not to treat emotions as risky (in the sense of potentially causing psychosomatic complaints).
} 
irrelevant whether these were caused by $\mathrm{CO}_{2}$ leakage or by fear of leakage; they could be real nonetheless. After their visit to Barendrecht, the national Ministers commissioned several new studies, including one on safety and one on the health effects of public safety concerns.

RIVM was asked to investigate the latter overflow. Unsurprisingly, the research institute found that it was impossible to scientifically assess the risk of health complaints caused by safety concerns (or by general discontent regarding CCS). There was simply a lack of experience with onshore CCS projects and since Shell had failed to conduct a baseline survey of local health complaints before the controversy started, any post-hoc measurement had become unreliable. ${ }^{187}$ The overflow was thus not further taken into account. National Ministers stressed that they would base their decision only on facts instead of emotions. ${ }^{188}$

DCMR was asked to bundle all of the safety knowledge which had been accumulated after publication of the MER-Barendrecht. ${ }^{189}$ As Arie Deelen put it, it was hoped that this Integral Safety Report would allow for authoritative decision-making after all:

"Decision-makers relied heavily on this. Also in the sense of: 'Dear DCMR, dear Safety Region, dear et cetera, tell us: is it safe or not? It is justified to make this decision, yes or no?" (Interview AD)

Again, the verdict was positive: DCMR concluded that existing legal norms for external safety were met. ${ }^{190}$ In turn, the national Ministers indicated they would support Shell's project (despite the negative verdict of local and provincial politicians). But again, this was hardly the end of the controversy. In the next section, I will introduce three new critics, as their actions help to understand the dynamic of the risk controversy after decision-making power had shifted to the national level.

\footnotetext{
187 See: RIVM (2009). 'Advies gezondheidsklachten naar aanleiding van $\mathrm{CO}_{2}$ opslag in Barendrecht'. Letter to Interdepartementale Projectorganisatie CCS, 13 October 2009 (20090389/IMGLG).

${ }^{188}$ In their case-study on the controversial siting of a nuclear reprocessing facility, Shackley, Wynne \& Waterton (1996) argue that 'simplicity' of the risk situation was achieved by framing the debate as a factual versus emotional conflict wherein the social assumptions and commitments of the authorities were seen as non-negotiated prescripts and not as hypotheses. Opponents of the facility employed a wider frame (including for example the issue of radioactive waste, weapons, spin-off effects), but this was discarded as emotional: "A factual scientific approach meant containing the decision according to the official definitions of the risks of the THORP plant alone" (Shackley, Wynne, \& Waterton, 1996, p. 209). A similar dynamic can be identified in the Barendrecht controversy: given the institutionalized framing of the MER, the critics' call for a broader framing could be dismissed as either emotional or politically-biased.

${ }^{189}$ This for example included new models on the behaviour of people when trying to escape from a tunnel in which non-lethal concentrations of $\mathrm{CO}_{2}$ have accumulated.

${ }^{190}$ With the exception of one section of the designated $\mathrm{CO}_{2}$ pipeline, but this could be solved via technical mitigation measures.
} 


\subsubsection{Uncertainty claims and the mobilization of a concerned public}

Krijn de Jong is a Professor in Inorganic Chemistry at Utrecht University. He was enrolled in the national research program CATO for his expertise in $\mathrm{CO}_{2}$ capture. However, the professor was sceptical about the feasibility and desirability of large-scale CCS. In turn, De Jong considered it his academic duty to be critical of the knowledge routinely used in decision-making on concrete CCS projects. Adopting an almost Latourian vocabulary, he argued:

"Some colleagues said: 'Yes, if the MER is positive, it is safe'. Well, I would rather open the box to see what's inside. Perhaps it does not contain diamonds after all, but merely coals. Both are made of carbon, but still. ... I consider it my role as an academic to put the facts on the table. Of course, I have an opinion and am happy to indicate whether or not I would have done these calculations differently. But ultimately, the decision is made by politicians." (Interview KdJ)

Already in March 2009, De Jong had submitted a critical opinion piece to a national newspaper, arguing why " $\mathrm{CO}_{2}$ should not be stored, certainly not underneath Barendrecht." 191 The critique focused on the energy penalty involved in $\mathrm{CO}_{2}$ capture (his field of recognized expertise). Additionally, De Jong pointed to uncertainties in the deep underground. He argued that injected $\mathrm{CO}_{2}$ could chemically react with underground minerals, thereby increasing roughly $70 \%$ (!) in volume and potentially causing the surface to lift. This possibility was allegedly unaccounted for in the MER and thus constituted an overflow. De Jong concluded his article by stressing that safety of the project could not be guaranteed: "How safe is $\mathrm{CO}_{2}$ storage? No one knows." ${ }^{192}$ The claim of $70 \%$ expansion was heavily criticized by geologists and fellow scientists from Utrecht University. Faced with new information on the minerals present in the Barendrecht fields, De Jong later agreed that his crude calculation ("although theoretically correct") might have been misguided. His uncertainty claims nevertheless helped to mobilize a concerned public. This becomes clear when looking at the actions of two other prolific critics: Huub van Gorp and John Poppelaars.

Huub van Gorp had lived in Barendrecht for over 60 years. With his background in mechanical engineering and working experience at Shell Chemical Manufacturing and an international shipping company, Van Gorp felt that he had enough 'technical connoisseurship' to judge the safety claims of others. In March 2009, he registered to speak during a Theatre Session in Barendrecht. ${ }^{193}$ This session was meant to reiterate the framing of the Knowledge Table by facilitating an exchange between (i) local politicians and their consult-

\footnotetext{
${ }^{191}$ De Jong, K. (2009). 'Opslag $\mathrm{CO}_{2}$ in leeg gasveld is niet veilig'. In: NRC Handelsblad, 5 March 2009.

${ }^{192}$ Ibid.

${ }^{193}$ Gemeente Barendrecht (9 March 2009). 'Notulen Openbare Vergadering Commissie Ruimte’.
} 
ed experts and (ii) members of the affected public. But at this point in the risk controversy, such a division had become difficult to maintain. Although invited as an 'inhabitant,' Van Gorp started his speech by challenging the speaking time assigned to him and took on the role of 'critical expert' instead. Van Gorp qualified the "experimental" approach of Shell as "technically weak" and made three critical remarks. First, CCS involves a considerable energy penalty and therefore resembles 'carrying coals to Newcastle. ${ }^{194}$ Second, $\mathrm{CO}_{2}$ is an active gas which could chemically react with dissolved minerals that are present in the underground. These reactions may fracture the cap rock or may cause the surface to lift. Third, Van Gorp argued that monitoring (as discussed in the MER) would be of little value when something would actually go wrong. In conclusion, Van Gorp urged local politicians to vote against Shell's project, "due to the uncertainties involved and the counterarguments made by professors. ${ }^{\prime 195}$ This referred explicitly to Professor Krijn de Jong. ${ }^{196}$

The critical stance of Huub van Gorp was shared by John Poppelaars, a fellow inhabitant of Barendrecht and director of a consultancy firm specializing in economic risk analysis. Poppelaars had submitted several critical viewpoints on the MER, in which he questioned the necessity of CCS, the scientific link between anthropogenic $\mathrm{CO}_{2}$ emissions and global warming and the scientific quality of available safety studies. ${ }^{197}$ Like other critics, Van Gorp and Poppelaars wanted to base their criticism on techno-scientific facts alone. They for example distanced themselves from $\mathrm{CO}_{2}$ isNEE, an action group ${ }^{198}$ which used public protest to mobilize inhabitants in Barendrecht:

" $\mathrm{CO}_{2}$ isNEE focused mainly on the streets, on protesting. Mobilisation, you could say. But we were like: we should also have a technical approach. Knowledge-based. We wanted to have an impact, not merely by shouting that the project is unsafe, but by also saying why it is unsafe and by showing that." (Interview HvG \& JP)

\footnotetext{
${ }^{194}$ In Dutch: water naar de zee dragen.

195 Ibid., p.4.

${ }^{196}$ Van Gorp did not refer to Van den Akker, the 'critical expert' enrolled by local politicians: "Er zat een emeritus hoogleraar [Van den Akker] die verstand had van geologie, maar die ging niet dieper de grond in dan een paar honderd meter. Daar had ik eerlijk gezegd geen hoge pet van op hoor. Ik bedoel, wat komt zo'n man praten over iets wat veel dieper zit? (smirks)" (Interview $\mathrm{HvG}$ ).

197 See: Poppelaars, J. (2010). 'Zienswijze Voornemen Project $\mathrm{CO}_{2}$-opslag Barendrecht', Inspraakpunt Project $\mathrm{CO}_{2}$-opslag Barendrecht, 29 September 2010, pp. 4-5.

${ }^{198} \mathrm{I}$ am hesitant to qualify $\mathrm{CO}_{2}$ isNEE as a local action group. Members were aware that criticism on Shell's project could easily be dismissed as NIMBY-ism. They strategically tried to mobilize other publics too (e.g. in Rotterdam and Northern Netherlands), for example by publishing rudimentary maps in national and local newspapers, sketching the location of gas fields which could potentially be used for $\mathrm{CO}_{2}$ storage in the future. After the Barendrecht controversy, representatives of CO2isNEE met with an action group in Northern-Netherlands (CO2NTRAMINE) to share knowledge on CCS and experiences in opposing CCS projects.
} 
Krijn de Jong, Huub van Gorp and John Poppelaars tried to play the role of 'critical experts'. They claimed to have (i) enough expertise to judge the safety claims of others and (ii) more affinity with public concerns than others with certified expertise on safety of CCS specifically (and thereby, an alleged professional interests in advancing CCS). Initially, their role was not recognized. The three critics had neither helped to draft the MER nor participated in the Knowledge Table Sessions. However, their role changed after they expressed their uncertainty claims in national media.

Mid-2010, two documentaries aired on national television. One was entitled ' $\mathrm{CO}_{2}$ bomb underneath Barendrecht,' made by Zembla. It suggested that national decisionmakers had overlooked the voice of critical experts. Righolt-Dam (CDA-Barendrecht) was shown, stating that she did not trust the MER and wanted to have more certainty on the risks involved. Huub van Gorp was interviewed while flying over Barendrecht in a small airplane. He pointed out that the designated injection point was surrounded by dikes. In case of major $\mathrm{CO}_{2}$ leakage, the resultant cloud could only go in one direction: towards residential areas. Krijn de Jong also figured prominently in this documentary. Sitting in a chemistry lab, he illustrated the suffocating effect of $\mathrm{CO}_{2}$ by pouring some of the gas onto a candle, causing the flame to die. De Jong added that the chance of $\mathrm{CO}_{2}$ leakage might be small but that the consequences in a residential area with 50,000 inhabitants were "potentially enormous." 199 The voice-over concluded:

"According to experts, there are still too many uncertainties involved in $\mathrm{CO}_{2}$ storage. We should first do restrained research in remote areas. Still, the Netherlands is rushing a controversial test underneath a residential area in Barendrecht. This means that we, perhaps for no reason, may cause a problem for future generations in Barendrecht."

Two weeks later, a second documentary was broadcasted. Again, it was presented as the outcome of investigate journalism:

"How do Shell and the Dutch government know for sure that $\mathrm{CO}_{2}$ storage is safe? Netwerk carefully examined the risk analyses and discovered that the studies might be flawed."

\footnotetext{
${ }^{199}$ Ibid. This public performance infuriated many of his colleagues. One, specializing in risk assessments for CCS projects, noted for example: "I considered it a grave journalistic blunder [journalistieke dwaling]... People are also not worried when opening a can of Coke... and that's the amount of $\mathrm{CO}_{2}$ release that we were talking about at some point" (interview JK). In retrospect, Professor de Jong acknowledged that his performance had partly been rhetorical. However, he legitimized this by referring to the political decision to place Shell's project under the Crisis- and Recovery Act. In his view, this had changed the 'rules of public engagement'. Again, Professor de Jong considered it his academic duty to instigate broad public debate on CCS and his participation in the documentary should be seen in this context.
} 
The documentary emphasized that DCMR played a double role: it had to assess safety of the Barendrecht project, but also wanted to advance CCS in the Rotterdam region. By way of clever montage, it was suggested that Arie Deelen (Head of DCMR's Expertise Centre) had withheld information on the limits of current risk assessment practices. 'Expertinhabitant' John Poppelaars was interviewed, saying that he did not trust the calculations of the MER. The documentary-makers stated that they had looked for independent experts to check the claims of Poppelaars and had eventually found only two: Krijn de Jong and Hans Pasman (Research Professor on Process Safety and member of the Dutch Adviesraad voor Gevaarlijke Stoffen). Both were quoted questioning the scientific validity of conducted risk assessments.

To sum up, the two media outlets frames critics as 'experts' and suggested that the MER-Barendrecht was flawed or biased. The documentaries thus threatened to undermine the epistemic authority of certified CCS experts. To understand their response, the next section will focus on the activities of CATO. This national research program aimed to bring together (and represent) 'the' Dutch community of CCS experts. CATO members studied topics like $\mathrm{CO}_{2}$ capture efficiency, trans-boundary $\mathrm{CO}_{2}$ transport, regulatory issues, public acceptance and risk/safety. It is worth noting that Professor de Jong was a member of CATO too, studying chemical aspects of $\mathrm{CO}_{2}$ capture. ${ }^{200}$ Few colleagues shared his critical stance. The next section will explore how CATO tried to facilitate an informed, authoritative decision on the safety of CCS. I will argue that the consortium tried to strike a delicate balance between two poles: (i) providing a clear, unambiguous message about safety and (ii) being open about the limits of knowledge and about dissenting viewpoints.

\subsubsection{The CATO research consortium and scientific authority}

Phase 1 of CATO ran from 2004 to 2008 . Receiving $€ 25.4$ million in funding, it brought together companies like Shell, NAM and Gasunie, research institutes ECN and TNO, scientists from the universities of Twente, Delft, Leiden and Utrecht and three environmental organizations: Greenpeace-NL, WNF-NL and SNM. The objective was 'to build a strong knowledge network, collect validated knowledge, analyze the societal and industrial base and generate the necessary technological expertise to prepare for the possible transition

\footnotetext{
${ }^{200}$ De Jong himself downplayed the significance of this enrolment. He stressed that CCS was only a marginal part of his research activities and that he had been critical of the technology from the start. There were two reasons for his involvement in CATO. First, one (of his fifteen) $\mathrm{PhD}$ students could receive a grant to work on the energy penalty involved in $\mathrm{CO}_{2}$ capture. Second, De Jong felt that participating in CATO made it easier to get involved in academic debates on CCS and to thereby go beyond merely shouting from the sideline: 'this will never work' (Interview KdJ).
} 
to large-scale use of CCS in the Netherlands.' CATO initially focused mostly on fundamental research. In Phase 2 (running from 2009 to 2014), the focus shifted towards applied research. Receiving nearly $€ 64$ million in funding, numerous additional partners from the power sector were enrolled as CATO increasingly aimed to support concrete demonstration projects.

CATO members conducted research on many topics relating to CCS. ${ }^{201}$ Here, I will discuss only those activities which were relevant vis-à-vis the Barendrecht controversy (see Table 2 below).

Table 2: Selection of CATO activities

\begin{tabular}{ll}
\hline 1 & conduct scientific research on safety/risks of CCS \\
2 & conduct scientific research on (public) risk perceptions \\
3 & engage in risk communication to structure and inform the public debate on CCS \\
4 & facilitate critical review of risk analyses \\
5 & open up the cultural space for 'expert' deliberations on safety of CCS \\
\hline
\end{tabular}

First, CATO conducted scientific research on the risks involved in CCS. Some members participated in international research groups, like the 'Risk Assessment Group' of the IEAGHG. Some members advised the Dutch regulator on how to develop an appropriate regulatory framework to handle the risks involved in CCS projects. According to Jacqueline Cramer (former Dutch Minister of Environmental Affairs), she could base her political decision to support the Barendrecht project on the majority opinion of CATO researchers:

"There was a large CATO programme, in which many researchers participated. I knew several of them. In essence, it resembled the climate debate. $99 \%$ of these researchers felt: it is safe. Safe enough and adverse consequences can be managed or controlled" (Interview JC, former-minister of VROM) ${ }^{202}$

So, based on techno-scientific studies, CATO tried to represent the broad scientific consensus that $\mathrm{CO}_{2}$ could safely be stored in depleted gas fields like the ones underneath Barendrecht.

\footnotetext{
${ }^{201}$ For an overview of all activities, see CATO (2009) and de Vos (2014).

202 Looking back, the former Minister of VROM recalled that the 'Barendrecht dossier' had involved several issues: site selection, safety and necessity of CCS. Each issue involved a different risk situation and thus warranted a different treatment (see e.g. Klinke \& Renn (2002) or Van Asselt \& Renn (2011) on ways to differentiate and handle simple, complex, uncertain or ambiguous risk situations). My analysis focuses primarily on the issue of safety. After reading the MER and consulting CATO, the responsible Ministers felt that enough was known about the health, safety and environmental impact of the Barendrecht project to warrant a 'classic' risk governance approach: experts were asked to assess the risks involved, after which political decision-makers related them to legal norms on external safety (WRR, 2009).
} 
Second, psychologists and social scientists conducted scientific research on risk perceptions and public opinions. An important finding was that most Dutch people hold 'pseudoopinions' on CCS. That is:

"Most lay people admit they have never heard of specific CCS options. Nevertheless, when asked, they provide their overall evaluations of these options instead of refraining from evaluation" (CATO, 2009, p. 40; De Best-Waldhober et al., 2009; see also De Best-Waldhober \& Daamen, 2006).

Problematic from an industrialist's perspective, such uninformed opinions are highly unstable. They can change within minutes depending on the information provided or the mood of the respondent. When respondents were provided with "relevant, valid, balanced and comprehensible information" though, only a minority seriously opposed to CCS. The conclusion was therefore that "after processing good quality information on pros and cons," the Dutch general public would "probably agree to large-scale implementation of CCS, although reluctantly" (CATO, 2009, p. 41). ${ }^{203}$ Another important finding on risk communication was that trust in the sender of a message matters even more than the content of this message. People trust environmental NGOs and research institutes like TNO more than industrial parties like Shell.

This insight shaped a third activity of CATO: members tried to inform the political and public debate on CCS via risk communication. CATO was in a tough spot here. Communication studies indicated that 'persuasive communication,' aiming to outright advocate CCS, was likely to be counterproductive in terms of public acceptance. ${ }^{204}$ So, mapping arguments pro and against CCS helped to appear independent and neutral. ${ }^{205}$ According to the former Minister of Environmental Affairs, CATO had acted as a 'neutral' knowledge broker in that respect:

"It was a scientific programme, not a lobbying club. Their role was not to formulate a political vision. But they can compare different viewpoints or they can monitor what is being said in the media and cluster this, so that all information on the pros and cons, on critics and advocates is listed. That is what they have done. ... But they never took a political stance or provided a judgement on the position of those in favour or against CCS.” (Interview JC, former Minister of Environmental Affairs)

\footnotetext{
${ }^{203}$ See Malone, Bradbury and Dooley $(2009 ; 2010)$ for a critical reflection on the role of public attitude surveys in enhancing stakeholder involvement on CCS. They argue that the framing of stakeholder / public involvement exercises (e.g. in terms of the goals, the issues under consideration and the role of expert consultation) is crucial for their success. Malone et al. (2009) warn against treating public involvement merely as a tool for probing, "in an 'advertising-like way', what characteristics of respondents could be used to 'sell' the idea of CCS” (p. 4792). ${ }^{204}$ Source: (CATO, 2009, p. 42; Terwel, Harinck, Ellemers, \& Daamen, 2009; Terwel, Harinck, Ellemers, Daamen, \& De Best-Waldhober, 2009).

${ }^{205}$ See also Van Egmond \& Hekkert (2012).
} 
During the Barendrecht controversy though, many conflicting claims on CCS had started to circulate in the public domain (see Section 3.6.1). In turn, CATO tried to inform the political and public debate on CCS by distinguishing between 'facts' and 'opinions. ${ }^{206}$ Several examples can be given. On the consortium's website, CATO's own Krijn de Jong was criticized for his role in the Barendrecht debate, as he allegedly had not contributed to an informed, fact-based public debate. CATO members helped to set-up several information points: one online (www.co2afvangenopslag.nl) and one in the centre of Barendrecht, where inhabitants could pose questions and collect information on CCS. Journalists were taken on a field trip to the Eifel to show that $\mathrm{CO}_{2}$ leakage, occurring naturally in that region, is not as dangerous as suggested in some newspaper articles. And CATO handed out black boxes, containing three samples each (Figure 13).

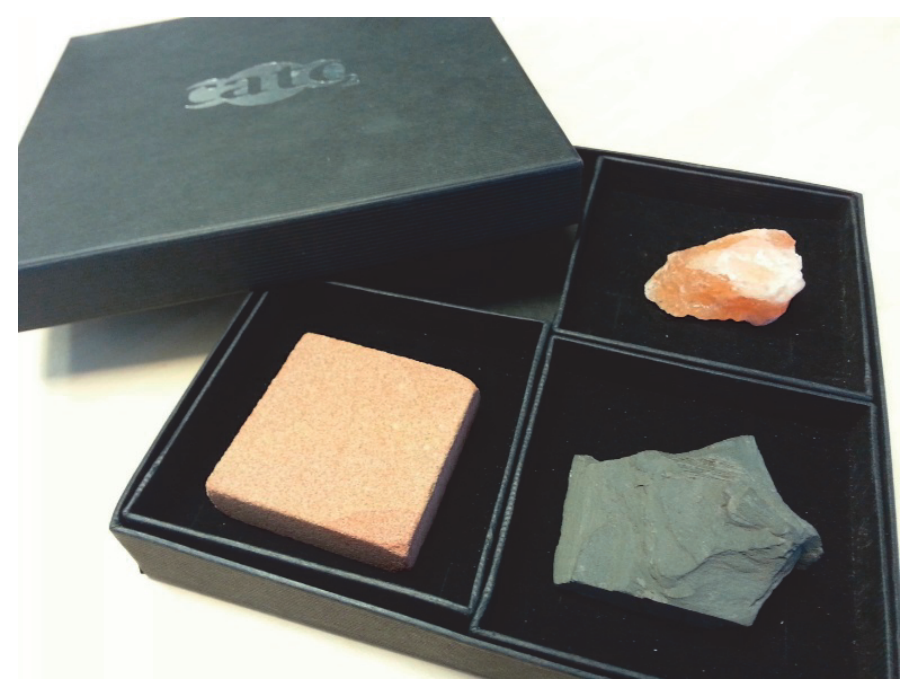

Figure 13: Box with exemplary samples from the deep underground Source: Personal collection of author, given by Program Director of CATO-2.

The piece on the left resembled the porous, brick-like stone of which gas fields consist. On the bottom right is a sample of the clay stone which covers reservoirs like the ones underneath Barendrecht. The pinkish element on the top right represents the salt minerals which act as a better, more flexible seal for the gas fields in Northern Netherlands. This black box was meant to make the deep underground (which had become a matter of concern) tangi-

\footnotetext{
${ }^{206}$ See: http://www.co2-cato.nl/nl/uitleg-co2-opslag/feiten-en-meningen. Archived under: http://www.webcitation.org/6U0UUcwTZ.
} 
ble and to avoid the misconception that a gas field is an empty space in the underground which could pop like a balloon when filled with $\mathrm{CO}_{2}$.

Again, CATO members tried to inform the public debate on CCS via risk communication, whilst being reluctant to take an outright 'political' stance in favour of CCS. However, a challenge remained: providing evidence on the safety of CCS could wrongfully be interpreted as a claim that all uncertainties were taken away. After all, risk analyses are designed to make informed decisions in light of uncertainty. But communicating these uncertainties was tricky too. As Maarten Hajer (Professor in Public Policy) notes in his research on authoritative governance in the contemporary Dutch society:

"What seems to be crucially new nowadays, is that political actors must constantly reckon with the fact that what they say at one stage, to one particular public, will often almost instantaneously reach another public that might 'read' what has been said in a radically different way and mobilize because of what is heard" (Hajer, 2009, p. 46).

I would argue that the same is true for CATO members when communicating about the risks involved in CCS. On the one hand, they felt scientifically obliged to be open about the limits of knowledge. On the other hand, they increasingly realized that their uncertainty claims could be picked-up in different contexts and could thereby undermine the authority of safety studies. ${ }^{207}$ Uptake of the so-called AMESCO study is illustrative here. ${ }^{208}$ As a generic environmental impact assessment, this study had served as an important basis for the MER-Barendrecht. But in the interpretation of some critics, it undermined the trustworthiness of this MER. An often-quoted section of AMESCO for example warns against calculating risks in a deterministic fashion:

"A dynamic learning process throughout the lifetime of the location is essential to judge the value of the models of the underground. Using models of the underground at a particular moment in time (e.g. during the permitting process) to make

\footnotetext{
${ }^{207}$ A similar dilemma can be noted for proposed risk management options. As a geologist of the Netherlands Organisation of Applied Scientific Research (TNO) recalled, plans to install monitoring devices (e.g. in the basements of inhabitants) were proposed to increase safety of the project, but only increased public safety concerns: "I was there, at a public information session in Barendrecht. ... We felt that it could safely be done. But then some citizens came to me and said: 'I don't believe that it is safe'. On such an occasion, you can say the opposite, you can put one report on the table, you can put fifteen reports on the table, but it does not matter. I find that very frustrating. ... Perhaps we became more careful after that with the way that we described our findings. .... Let me put it like this: the interpation in the public domain is difficult to predict. When we are saying: $\mathrm{CO}_{2}$ can safely be stored in one location and we suggest a monitoring plan, this can be interpreted in two ways. It is safe, but monitoring makes it more safe. No. The interpretation is: 'if storage is safe, why do you propose a monitoring plan?' Ok, you tell me, what should I do?” (Interview FN, geologist at TNO and project manager FP7, CATO). ${ }^{208}$ See: AMESCO. (2007). Generic environmental impact study on $\mathrm{CO}_{2}$ storage. Royal Haskoning, Ecofys, TNO, CE-Delft \& Golder.
} 
absolute prediction, does not seem to be useful because such a 'snapshot' is unsuitable for a system that is relatively unfamiliar and of which (some) properties will only gradually become clear." 209

According to critics, this meant that scientific risk assessments should only play a limited role in political decision-making. Project advocates strongly disagreed with this interpretation. Margriet Kuijper (Shell's Project Manager and former member of AMESCO's steering committee) stressed for example that the section referred to injection in aquifers, where reservoir conditions are poorly known. Gas fields pose a different situation, with smaller risks and fewer uncertainties. During the Barendrecht controversy, CATO members had gone out of their way to communicate this difference to various audiences. To little avail. Some critics overlooked the difference between aquifers and depleted gas fields all together. Others pointed to AMESCO as evidence that uncertainty and lack of practical experience undermined the trustworthiness of even the best safety studies.

This relates directly to a fourth activity of CATO: it tried to facilitate critical review of risk analyses. Emphasis on scientific consensus could lead to under-exposure of dissenting views and made CATO vulnerable to the accusation of political bias. ${ }^{210} \mathrm{So}$, a $\mathrm{PhD}$ researcher in Science \& Innovation Studies at Utrecht University was for example hired to act as an academic 'thorn in the side' of the CCS community. Joris Koornneef studied knowledge gaps regarding health, safety and environmental consequences of CCS. He examined, amongst others, the strengths and limitations of the Barendrecht MER study. Koornneef found that knowledge gaps and uncertainties had "a large effect on the accuracy of the assessed risks" (2010, p. 231). Using different assumptions and different models, there was a considerable range in calculated risks. Koornneef and his colleagues (2010) urged regulators to develop clear standards and guidelines for risk assessments to reduce this spread. This plea for standardization is visible within the international CCS community more broadly. ${ }^{211}$ Arguably, standardization of terms and of risk assessment approaches was meant to act as a 'trust device' (Halffman, 1998) in two distinct ways. First, standardization could help to avoid confusion amongst stakeholders and the wider public on important terms like

\footnotetext{
${ }^{209}$ Ibid., p. 127. For more on the treatment of uncertainty in risk analyses for geological systems, see e.g. CSLF (2009). 'Phase I Final Report from CSLF Risk Assessment Task Force', Carbon Sequestration Leadership Forum, November 2009.

${ }^{210}$ Van der Sluijs et al. (2010) argue that IPCC's 'consensus' treatment of the uncertainties in climate science is also problematic in this respect.

211 This plea is visible within the broader CCS community too. See for example: IEA-GHG. (2004). Risk assessment workshop (February) (No. PH4/31). International Energy Agency - Greenhouse Gas R\&D Programme. IEAGHG. (2005). Launch meeting of the risk assessment network. TNO-NITG/International Energy Agency - Greenhouse Gas R\&D Programme. IEA-GHG. (2006). Summary report of 2nd risk assessment network meeting (draft). Lawrence Berkeley National Laboratory / International Energy Agency - Greenhouse Gas R\&D Programme.
} 
'leakage', 'seepage', 'risk' and 'safety'. Second, it could help to compare and potentially benchmark the various risk assessment approaches that were being used worldwide. By 2010, such standardization had not yet occurred. Therefore, Koornneef et al. (2010) argued that there was room for improvement. Importantly, they also found that Dutch safety norms could be met in early CCS projects (like the one in Barendrecht), despite remaining uncertainties and despite the spread in risk approaches.

To sum up, CATO members critically reviewed the available risk approaches (as a form of quality control) and communicated the resultant safety knowledge to political decisionmakers and the broader public. However, there was yet another challenge. Critics questioned the 'objectivity' and 'independence' of certified experts. Increasingly, some members of the CCS community also started to suggest that this 'independence' could not simply be presumed. In January 2010, Heleen De Coninck (researcher at ECN and coordinator of IPCC's Special Report on CCS) for example wrote a letter to the editors of Nature, in which she argued that CCS experts should not be CCS advocates:

“Academics' valuable time would be better spent on research into the limitations, rather than on advocacy. CCS has plenty of powerful support in politics and in industry" (de Coninck, 2010)

De Coninck expressed a similar concern in March 2010 in an interview in De Volkskrant. She noted a change in attitude. Initially, a small group of experts had gathered at international conferences and had reflected upon the future of CCS in a critical way. The authors of IPCC (2005) for example had tried to be "as objective as possible" by avoiding prescriptive formulations and avoiding words like 'favourable,' 'promising' and 'early opportunities.' However, as national governments and industrial parties had become interested in CCS, this attitude had allegedly changed:

"There is no longer an academic atmosphere at the conferences. Government and industry have become enthusiastic. Unknowingly, experts have joined this enthusiasm. I have seen the CCS community change from a small, self-critical group of scientists to a much larger group, primarily congratulating itself." 212

To be clear, De Coninck did not suggest that CCS was unsafe or that safety studies were biased by economic or political agendas. However, her call for self-criticism and transparency did affect CATO's work.

Over time, CATO engaged in a fifth activity: it tried to open-up the cultural space for 'expert' deliberations on safety, so that critical voices and dissenting opinions were accom-

\footnotetext{
${ }^{212}$ Persson, M. (2010). 'Onenigheid over $\mathrm{CO}_{2}$ opslag', De Volkskrant, 19 March 2010. Other than suggested by some journalists and politicians, De Coninck's call for self-criticism and non-advocacy should not be understood as a plea against CCS. See also: ECN (22 March 2010). 'Letter to Ministry of EZ on ECN's position regarding CCS and De Coninck's interview in De Volkskrant', Energie Centrum Nederland.
} 
modated. An anecdote may illustrate the dramaturgical character of this activity. During an annual meeting of the Dutch CCS community, Jan Brouwer (Program Director CATO) decided to stage a performance. Actors were hired to play emotional members of the public, posing critical questions. Brouwer deliberately responded "in the wrong way" and had them evicted from the premises. As the Program Director recalled, the scene triggered a lot of debate amongst the gathered CCS professionals:

"I was walking upstairs to get some gifts for the actors. There, colleagues were buzzing: 'we have intruders, who have entered the CATO meeting and are being physically expelled!' But we had plotted it like this on purpose, to indicate that there may indeed be some truth in it, in the way that we shield ourselves from the rest of the world and of the type of discussions that we have amongst ourselves." (interview JB)

The performance was meant to encourage self-reflection. Besides conducting extra scientific studies and communicating risks and uncertainties to the outside world, CATO also decided to broaden the scope of participants in expert discussions (if only to show that the Dutch CCS community took public safety concerns and the arguments of critics seriously). This fifth activity also gave rise to a hybrid forum on the Barendrecht project specifically, as the next section will explore.

\subsubsection{The Fact Finding Workshop as a hybrid forum}

In May 2010, CATO organized a so-called 'Fact Finding Workshop' on the Barendrecht project. This workshop had two objectives: to identify the main points of disagreement and to suggest, where possible, constructive steps which could break the deadlock. Professionals with certified expertise in CCS were invited, but so were prominent critics: Krijn de Jong, Huub van Gorp and John Poppelaars. First, all participants sketched their involvement in Shell's project. Then, two critics got the opportunity to give a short presentation on their arguments. After this, a representative of an engineering firm gave an update on risk assessment methodologies and on knowledge gained after publication of the MER. Finally, the chair and other participants had time to question the presenters. Three journalists were invited to observe the discussions. ${ }^{213}$ Organizers hoped that this performance would provide the media with a balanced picture of the risks involved in CCS and would show that experts discussed the (limits of) scientific knowledge in an open, unbiased manner to the outside world.

\footnotetext{
${ }^{213}$ Access to the workshop's documents was granted by John Poppelaars, who also gave permission to make direct reference to his argument (which can also be found in the critical viewpoint which he submitted in response to the MER).
} 
Content-wise, disagreement centred mostly on the risk that $\mathrm{CO}_{2}$ would escape from the transportation pipeline or the injection well. Critics argued that the institutionalized computer model (Safeti-NL) had fallen short to assess this risk. It could for example not mimic a situation in which there was no wind and had arguably failed to take relevant elements of the local context into account (like dikes and highways). If $\mathrm{CO}_{2}$ were to escape under low pressure and on a day with little wind, it could act as a suffocating 'blanket' as it is heavier than air and displaces oxygen. Critics used meteorological data to show that low wind speeds were not uncommon in Barendrecht and pointed to an analogue experience: in August 2008, a considerable amount of $\mathrm{CO}_{2}$ had leaked from a fire extinguish system in a factory in Mönchengladbach. Due to the low pressure of the escape, nearby obstacles and weather conductions, the $\mathrm{CO}_{2}$ spread over a distance of hundreds of meters. Emergency vehicles had difficulty reaching the scene because their engines were smothered and numerous people experienced (non-lethal) health effects. This experience was used to underline that a low-pressure release of $\mathrm{CO}_{2}$ on a day with low wind speeds was a worst-case scenario which should (but could not be) accounted for in Safeti-NL and thus constituted an overflow. ${ }^{214}$

Furthermore, critics argued that quantitative risk assessments entailed considerable expert judgment. ${ }^{215}$ Reference was made to studies by Koornneef (CATO's academic 'thorn in the side'), who had found that different computer models resulted in significantly different risk numbers. To reduce this spread, Koornneef et al. (2010) had urged the Dutch regulator to develop clear guidelines for quantitative risk assessment. But critics emphasized that such unification would not increase the 'reality content' of calculated risks. They quoted an academic paper by Hans Pasman (Research Professor on Process Safety and member of the Dutch Advisory Council for Hazardous Substances):

"To get rid of spread in risk analysis results by prescribing (by law) the use of one particular model, in one particular version with a particular set of model options is scientifically unsatisfactory. User influence on the results is this way minimized, but the reality content remains questionable" (Pasman \& Fabiano, 2008, p. 7)

Critics also questioned the practical use of QRAs more generally. A report by the Dutch Advisory Council for Hazardous Substances was quoted to argue that QRAs should not be

\footnotetext{
${ }^{214}$ Here too, reference was made to people with recognized expertise in risk assessment. In a personal communication, Ben Ale (Professor in Risk Management, TU-Delft) had for example written to John Poppelaars: "De huidige QRA modellen zijn verouderd, met name op het punt van het modelleren van de dynamiek van gaswolken in bebouwde regio's" (quoted in Poppelaars'submitted viewpoint).

${ }^{215}$ Like members of CATO, project critics also drew on scientific studies on risk perceptions. They for example referred to the work of psychologists Kahneman \& Tversky (1972) on 'subjective probabilities' to underline that 'experts' (like all people) tend to rely on simple heuristics when making judgments under uncertainty, which may result in systematic errors. So, cognitive processes were presented as overflows of the conducted risk calculations, undermining their truth value.
} 
used as an absolute basis for decision-making. ${ }^{216}$ Instead, they should be used to inform (and be informed by) an early dialogue between various stakeholders on safety of a project and on priorities in risk management.

As a hybrid forum, the Fact Finding Workshop triggered several new lines of inquiry. ${ }^{217}$ However, it failed to break the dead-lock. For many participants, the bottom-line was that a CCS demonstration project had to comply with existing regulations (i.e. legal norms on external safety). There was thus an institutional pressure to 'close down' understandings of potential consequences of Shell's project to the narrow terms of risk. ${ }^{218}$ At the same time, critics insisted that the truth value of these calculated risks was limited.

\subsubsection{Problem structuration and multi-level tensions}

In the sections above, I have suggested that CATO members tried to safeguard their scientific authority and tried to inform political decision-making on CCS by navigating between two poles. On the one hand, there was a 'regulative' pressure to provide a clear, unambiguous message on the risks involved in the Barendrecht project, following established legal norms and risk assessment procedures. On the other hand, there was a 'reflexive' tendency to be open about dissenting opinions, about the limits of established risk approaches and about the ambiguity of safety knowledge. This reflexive tendency resulted for example in the so-called Fact Finding Workshop, in which some critics were enrolled as 'critical experts'. However, this framing was exception rather than rule. In most other discussions at

\footnotetext{
${ }^{216}$ Adviesraad voor Gevaarlijke Stoffen. (2010). Risicoberekening volgens voorschrift: een ritueel voor vergunningverlening.

${ }^{217}$ Critics argued for example that models of the dispersion of a $\mathrm{CO}_{2}$ release under varying circumstances were hardly validated by practical experience or field tests. Making such models is challenging due to, amongst others, the complex phase changes (dense, vapour, solid) of the $\mathrm{CO}_{2}$ flow (Witlox, Harper, \& Oke, 2009). Early validations that were done by firms like DNV and BP often involved confidential information. So, critics argued that safety protocols could be informed by accidents like the one in Mönchengladbach and that simulations should be done on major leakage from high-pressure $\mathrm{CO}_{2}$ pipelines. Members of CATO acknowledged that such (expensive) research could reduce the uncertainties involved. However, they also stressed that it could take years before such knowledge was publicly available and could thus not be used for decision-making at that moment in time. CATO2 invested heavily in theoretical and experimental research on the risks involved in transporting $\mathrm{CO}_{2}$ via pipelines. For scientific publications on this, see (Hulsbosch-Dam, Spruijt, Necci, \& Cozzani, 2012; Ahmad et al., 2013; Mack \& Spruijt, 2014).

${ }^{218}$ Compare: "Contrasting representations of the completeness or quality of knowledge are not politically symmetrical. Powerful imperatives to deploy knowledge as a means to justify, persuade and legitimate very often force a process of 'closing down', [where] system dynamics and their implications come to be treated in terms of 'risk'” (Leach et al., 2010, p. 78).
} 
the national level, the classic distinction between certified experts and lay-people was maintained. ${ }^{219}$

Already in 2009, Shell had for example financed the National Energy Dialogue on CCS $(\mathrm{EDN}){ }^{220}$ This dialogue brought together over 80 certified experts, opinion leaders, environmental groups and other stakeholders from the energy field. It was meant to increase mutual trust and understanding by debating the Dutch energy future, "of course with a sharp eye for the place of the Netherlands in international energy policy." 221 As the Chair of the EDN recalled, it was hoped that structuration of the expert debate at the national level would improve decision-making on concrete CCS projects like the one in Barendrecht:

"We tried to structure the national opinion leader discussion. Knowing, and this was more relevant for Shell than for us, that any NIMBY discussion would encounter a fundamental discussion [on the necessity of CCS] at the national and international level. So the idea was: we will investigate whether it is possible to achieve a certain consensus amongst Dutch opinion leaders at the national level. If so, parties like Shell and the national government could engage in debates on specific CCS projects, like the one in Barendrecht, against the background of a more harmonized discussion. To be sure, this consensus was not an end by itself. We were looking for a constructive dialogue." (interview JvS, chair of Energy Dialogue Netherlands).

After deliberations, most participants agreed that CCS should play an important role in the Dutch energy future. In November 2009, EDN published yet another report, entitled: Why CCS, why a demonstration project, why onshore, and why in Barendrecht? It stressed the necessity of CCS. ${ }^{222}$ Additionally, it underlined that there was consensus amongst 'true' experts that $\mathrm{CO}_{2}$ could safely be stored in depleted gas fields:

"Notwithstanding some nuances, all experts agree that $\mathrm{CO}_{2}$ storage in depleted gas fields does not entail any noteworthy risks. In essence, the risks of $\mathrm{CO}_{2}$ storage are in a purely technical perspective (risk $=$ change*effect) smaller than those in the storage of, or simply the natural presence of, natural gas. ... Conclusion: there are

\footnotetext{
${ }^{219}$ In fact, the distinction played a role in the frame of CATO's workshop too. In retrospect, Krijn de Jong felt that the 'expert-inhabitants' from Barendrecht could match the level of knowledge of other participants. But in the workshop's final report, one of these participants venomously ascribed the rift between project advocates and project critics to a rift between 'experts' and 'lay people'.

${ }^{220}$ Although Shell financed this dialogue, it did not demand a fixed outcome. By that time, the Dutch government had already embraced CCS as a third pillar of its energy policy. This was also the reason why the Dutch government would not subsidize this particular, open-ended dialogue on the need and necessity of CCS. ${ }^{221}$ EDN. (2009). $\mathrm{CO}_{2}$ afvang en -opslag: Vijgenblad, noodzakelijk kwaad of wereldkans? - Eindrapport EDN CCS Dialoog. Energie Dialoog Nederland. See also Chapter 2.

222 "De noodzaak van CCS in het klimaatbeleid is onbetwist. O.a. de EDN-dialoog heeft laten zien dat vanuit een internationaal en nationaal nut- en noodzaakperspectief vrijwel niemand aan de onontkoombaarheid van CCS twijfelt. Dat NL een belangrijke rol heeft te vervullen is evenmin punt van discussie” (Source: Ibid., p.1.)
} 
no substantial arguments against continuation of the project that will also really be understood as substantial [in Dutch: inhoudelijk]. Cancellation of Barendrecht will be understood as a political reconsideration, where the government caved in to local protests." 223

Participants of the National Energy Dialogue thus suggested that critics of the Barendrecht project were (i) lay persons and/or (ii) representatives of an (ill-informed) local public. ${ }^{224}$ After all, scientific studies on risk perceptions indicated that an informed public would, "after processing good quality information on pros and cons," "probably agree to large-scale implementation of CCS" (CATO, 2009, p. 41). If elected politicians would cave to local pressure, the implementation of CCS would be significantly delayed. This would make it more difficult (and more expensive) to realize national climate goals, so the report stated.

Indeed, the Barendrecht project was ultimately cancelled after a shift in political representation. In February 2010, the Dutch Cabinet collapsed over participation in the Afghan war. The Minister of Environmental Affairs was forced to resign. Her colleague at Economic Affairs emphasized that a political decision on Barendrecht would only be made after the national elections and that it would take (i) safety and (ii) public acceptance into account. In May 2010, CATO researchers conducted a survey amongst 800 inhabitants of Barendrecht. ${ }^{225}$ The outcome was clear: $80 \%$ of the respondents considered Shell's demonstration project "unsafe," whilst $86 \%$ felt that it was "unacceptable." This could not be ascribed to climate scepticism: the vast majority of respondents felt that climate action was desirable. Respondents did seem to questions the effect that the Barendrecht project would have though: only $19.4 \%$ considered it very likely that it would actually help to prevent global warming. One month later, the liberal VVD and right-wing PVV won the elections. VVD preferred nuclear power over new coal plants (with or without CCS). PVV politicians, denying anthropogenic climate change, felt that no public money should be spent on $\mathrm{CO}_{2}$ storage. During the formation, the energy dossier became heavily lobbied and local

\footnotetext{
${ }^{223}$ Ibid, p.9. See also: "[The EDN made clear] that there was broad consensus that safety was not an issue (with proper site selection and design) but that opinions were still divided on the need for CCS, the effectiveness of CCS, and the conditions under which CCS (and government funding of CCS) would be acceptable" (Kuijper, 2011, p. 2633).

${ }^{224}$ Their ability to represent the local public was questioned too. Although public meetings in Barendrecht had often turned into 'theatres of dissent' (Boholm, 2008), it was unclear whether the critics who were so vocal at these events also spoke for other inhabitants of Barendrecht (and of the Netherlands more broadly!). Some civil servants used another proxy for local acceptance: they monitored the turnover of Shell's petrol station in Barendrecht. The fact that there was no abnormal pattern in sales during the controversy was taken as an indication that local resistance against Shell was not widely shared.

${ }^{225}$ Daamen, D., Terwel, B., \& ter Mors, E. (2010). Wat weten en vinden Barendrechters van het $\mathrm{CO}_{2}$ opslag plan en van voorlichting en besluitvorming over dit plan? Resultaten van een enquête in mei 2010 onder ruim 800 inwoners. Available at website of CATO-2.
} 
politicians in Barendrecht were often in direct contact with national politicians from the PVV. In October 2010, VVD and CDA formed a minority government with support of PVV. One month later, Maxime Verhagen (the newly-appointed Minister of EZ) spoke to his CDA-colleague in Barendrecht to see if there could ever be local acceptance for CCS. RigholtDam indicated that this would not be the case. A few days later, political support for Shell's project was withdrawn. Time delays and lack of public acceptance were cited as official reasons. Some commentators have interpreted this as a victory of Dutch climate sceptics (Vergragt, 2009a). Others have condemned the political decision for leaving the issue of 'safety' unsettled. ${ }^{226}$

\subsection{CONCLUSION}

This chapter has examined how actors tried to come to an authoritative verdict on safety of the Barendrecht project. All responsible politicians insisted that they would base their decision on techno-scientific facts alone. The perspective on frames and overflows highlights that the production of relevant safety facts was hardly straight-forward though. As Callon et al. (2009, pp. 29-30) put it:

"Decision-makers think that the parameters of the questions to be dealt with have been suitably and properly defined, from both a technical and a political point of view, and now overflows identified by the actors demonstrate the opposite."

My analysis has also highlighted that actors reflexively looked for ways to contain such overflows. Both the Knowledge Table Sessions (Section 3.5) and the Fact Finding Workshop (Section 3.6) were procedural innovations. To inform political decision-making, they had to strike a delicate balance between increasing variety ('opening-up') and productive convergence ('closing-down') of actors and issues (Rip, 2003, p. 424). In both instances, some people were enrolled as 'critical experts.' Even though these people lacked certified expertise, their participation was legitimized because they (i) had sufficient general expertise to critically review the safety studies produced by others and (ii) had knowledge of local conditions and/or greater affinity with the questions and concerns of the affected public.

\footnotetext{
${ }^{226}$ After decision-making power had shifted to the national level, local politicians instigated a private party ('Veilig Duurzaam Barendrecht', chaired by Huub van Gorp) which was preparing to appeal in front of the Dutch Council of States. This judicial body would then have to judge whether the appropriate procedures had been followed and whether available safety studies had been correctly used. Both local politicians and members of the $\mathrm{BCO}_{2}$ indicated in interviews that they would have liked such a verdict, as it would have provided clarity for future CCS projects.
} 
In a sense, both hybrid forums put into practice suggestions made by sociologists of science Harry Collins and Robert Evans (2002, 2007). Collins \& Evans warn that it might become practically impossible to organize informed decision-making when the traditional epistemic justification for separating the claims of experts from those of lay people is denied (or is replaced by a democratic call for increased public participation in discussions on, as they assert, matters of fact). In turn, Collins \& Evans have proposed a 'normative theory of expertise,' according to which only specific uncertified members of the public should be allowed to participate in expert discussions, namely those who possess a core-set of expertise necessary to evaluate and understand the issues at hand. During the Knowledge Table Sessions and Fact Finding Workshop, a similar criterion was implicitly used. The hybrid forums were meant to provide a cultural space where a broad range of experts would feel free to challenge safety studies and assess the relevance and potential impact of remaining uncertainties. It was hoped that this would allow for authoritative decision-making after all.

The question then is: why was it so difficult to settle the issue of 'safety'? I can see two main reasons. First, it should be emphasized that the enrolment of relevant expertise is not strictly an epistemic problem, but a political one as well (Wynne, 2003). Demeritt (2006) criticizes Collins \& Evans for overlooking this aspect and argues:

"One reason that science is so often in the firing line in environmental politics is that all too often policy decisions are legitimated in purely technical terms, leaving opponents with only scientific grounds for contesting policies that they oppose for other reasons." (p. 473)

This dynamic is visible in the Barendrecht case too. In June 2009, local and provincial politicians voted against Shell's project due to remaining uncertainties and public safety concerns. However, decision-making power shifted to the national level. The responsible Ministers followed the classic, regulative approach towards risk governance. They emphasized that they would only withdraw political support for Shell's project if there was conclusive techno-scientific evidence that safety could not be guaranteed. This was not because the Ministers felt that 'safety/risk' was the only issue worthy of consideration. Rather, other relevant issues (i.e. the necessity of CCS) had already been discussed in different forums at the national level. All of the critics mentioned in this chapter wanted to base their objections on facts. At the same time, they were concerned about other issues than safety alone (e.g. economic consequences, the feasibility and desirability of CCS as a climate strategy, the reality of global warming or fairness and procedural justice). ${ }^{227}$ Given the institutional tendency to 'close-down' deliberations to the narrow issue of safety/risk, they could only

\footnotetext{
${ }^{227}$ Terwel et al. (2012) found that most inhabitants of Barendrecht were concerned about other issues than safety alone.
} 
oppose Shell's project by questioning the completeness and quality of conducted safety studies and suggesting that there (unavoidably) remained uncertainties.

Second and related, the appropriate relation between 'experts' and 'the affected public' was contested too. Political theorist Mark B. Brown has pointed out in his book Science in Democracy that 'representation' is a key aspect of democracy (M. Brown, 2009). Scientific representation means that an actor (e.g. a graph, a number, an expert) is able to stand for entities and phenomena in the natural world. Political representation means that some are legitimized to speak and decide for others, with elections, referenda and votes of noconfidence as the institutionalized ways for orchestrating the relation between political spokespersons and their constituencies. During a controversy though, the 'double democratic divide' between (i) experts and lay people and (ii) publics and their political representatives is challenged. As Sheila Jasanoff notes in a review of Brown's book, this raises new demands for achieving a socially robust solution on contested techno-scientific developments:

"It makes sense to ask not only whether a scientific claim bears a reasonable relation to nature, but also whether the people making the claim are the right kinds of people to speak for the phenomena they represent. Indeed, if one looks at current debates in environmental policy (...), disputes often centre on the credibility of particular spokespersons rather than the reliability of their claims. In this respect, a core question of democracy-how good are our representatives- has infiltrated science" (Jasanoff, 2010c)

This is visible in the Barendrecht controversy too.

At turbulent information sessions in the local theatre, audience members questioned whether certified experts could be trusted to include all relevant elements in their studies and whether they were the right people to speak about safety. So, local politicians consulted 'critical experts' instead, asking them to take questions and concerns of the affected public into account. In turn, affinity with public concerns became an important precondition for trustworthy expertise. ${ }^{228}$ This was problematic though, as both local and national politicians insisted that an authoritative verdict on safety should be based on facts and 'nonpolitical' considerations alone. Critics presented themselves as (i) knowledgeable enough to challenge the safety claims of certified experts and (ii) representatives of 'the' affected public. This role warranted them a seat in some hybrid forums. But at the national level, the same role made them vulnerable to the accusation of (i) lacking relevant expertise on safety

\footnotetext{
${ }^{228}$ Sometimes, this call for 'affinity' was quite literal. During Theater Sessions, some audience members argued for example that the home addresses of politicians and their consulted experts should be made public. The suggestion seemed to be that only those living in Barendrecht could be trusted to make collective decisions, as they would themselves be exposed to the uncertainties consequences of their actions.
} 
and (ii) bias as they had an alleged interest in (or ideological reasons for) opposing CCS. As a result, the issue of 'safety' remained unsettled.

The present chapter has explored how actors tried to come to an authoritative decision on a concrete CCS project. My analysis made clear that decision-making is framed (and thus partly structured) by existing rules and regulations. Think of the regulations on external safety, suggesting that a semi-quantitative risk analysis was an appropriate way to generate knowledge on safety of the Barendrecht project. Regulation in general plays an important role in the governance of CCS. But rules and regulations are not fixed. In fact, actors deliberately renegotiate and reflexively update regulations as they try to govern timely implementation of CCS. To understand how such regulations are legitimized (and how knowledge on CCS gets negotiated in the process), a perspective on 'boundary work' is helpful. The next chapter will focus on a specific piece of regulation. It was introduced in a context where it seemed almost self-evident that commercial-scale CCS was 'feasible' (which is the third element of the dominant discourse pushing for CCS). Nevertheless, the feasibility of CCS became heavily contested during the regulatory process and it proved difficult to govern commercial-scale application of CCS. 



\section{4}

A promising or proven technology? Boundary work in the regulation of commercial-scale CCS 
From the 1990s onwards, studies have indicated that it is technically feasible to link CCS to a commercial-scale power plant (e.g. Hendriks, 1994; IEA-GHG, 1994; Holloway, 1996). Such studies have helped to legitimize that billions of dollars were invested in research and demonstration of clean coal technologies. This chapter will focus on a context where commercial-scale CCS seemed particularly feasible: the United States of America. The US underground provides ample space to $\mathrm{CO}_{2}$ emissions and coal had traditionally played an important role in the American energy mix. Already under the George W. Bush Administration, developing clean coal technologies became an important policy objective. The prospect of large-scale CCS came to act as 'political glue'. It helped to align industrial and environmental agendas and allowed parties to bargain financial support for CCS development with political support for stringent climate action (Meadowcroft \& Langhelle, 2010; Pollak, Phillips, \& Vajjhala, 2011; Wilson, Zhang, \& Zheng, 2011). In 2009, under the Obama Administration, the US Environmental Protection Agency (EPA) started a process to introduce a $\mathrm{CO}_{2}$ standard for new power plants. ${ }^{229}$ This standard had to be stringent enough to mitigate climate change, but not overly stringent as to stifle the implementation of CCS (Herzog, 2009; see also Wiener (2004) more broadly). In the regulatory process, the feasibility and readiness of CCS technologies became fiercely contested. This chapter explores how EPA tried to legitimize a stringent $\mathrm{CO}_{2}$ standard and why this was so difficult to achieve.

Before introducing the analytical perspective of this chapter, it should be noted that the United States is marked by a different energy imaginary than the Netherlands. Gjefsen (2013) has for example recently argued that CCS policies in the US are guided by a sociotechnical imaginary, according to which clean coal technologies can help to achieve energy independence and alleviate the nation's reliance on foreign oil (see also Stephens 2009). In the American imaginary, political support for the development of CCS is legitimized by presenting individual businesses and consumers as the ultimate beneficiaries of innovation. This has important governance implications too. In the US, there is for example less room for national energy dialogues and the federal government did not request a 'master plan' for the national implementation of a shared $\mathrm{CO}_{2}$ pipeline infrastructure, as the Dutch government did. Instead, the US government focused more on supporting cutting-edge research on clean coal technologies, guided by the prospect of technology transfer to other

\footnotetext{
${ }^{229}$ Several other rules to govern commercial-scale CCS were recently introduced in the US, like the 'Federal Underground Injection Control Class VI Program for $\mathrm{CO}_{2}$ Geologic Sequestration Wells' (under authority of the Safe Drinking Water Act) and the 'Greenhouse Gas Reporting Rule' (under authority of the Clean Air Act). Such rules are meant to reduce barriers to widespread development of CCS. This chapter will only focus on the New Source Performance Standard, as this triggered renewed debate on the 'feasibility' of CCS and is the only rule which is explicitly meant to ensure timely and sufficient abatement of new coal-fired power plants. In other words, it is the only US rule which is meant to govern the commercialization of CCS.
} 
countries. In the set-up of early CCS projects, differences can be observed as well. In the US, great emphasis is placed on the enrolment of local stakeholders (not least because private landowners own subsurface rights, as noted by Gjefsen (2013 p. 75)). Municipalities were for example asked to compete against each other in hosting the nation's flagship CCS project. And in decision-making on CCS demonstration projects, framing has typically centres on local economic consequences (e.g. the creation of high-skilled jobs or the effect on local energy bills) (Stephens et al. 2011).

Indeed, the implementation of CCS is governed differently in the US than in the Netherlands or in the EU. I do not intend to explore such trans-Atlantic differences though. It is generally recognized that the implementation of CCS has been slow in the United States too and that numerous CCS projects have recently been cancelled. I will sketch characteristics of the American context when I think that they are relevant for understanding how EPA tried to implement a regulatory standard which could incentivize, ensure and govern commercial-scale application of CCS for new American coal plants.

\subsection{STANDARDS, EVIDENCE AND BOUNDARY WORK}

In their study on standard-setting in the telecommunication sector, Schmidt \& Werle (1998) distinguish two types of standards: coordinative and regulative standards. Coordinative standards tend to be self-enforcing and often develop gradually over time. By reducing transaction costs, the likelihood of compliance increases and some form of 'path dependence' or lock-in occurs. ${ }^{230}$ Bodies like the International Organization for Standardization (ISO) have come to play an important role in the negotiation of coordinative standards. Tineke Egyedi (2000) for example studied how the dimensions of freight containers became standardized in the 1960s. The resultant 'ISO container' became a gateway technology, in the sense that it created both technical compatibility and the alignment of national transport policies and operator interests (see also Egyedi, 2000). Coordinative standards and other socio-technical conventions, e.g. on the size of electricity plugs, are powerful ways of governing society (Higgins \& Larner, 2010).

Regulative (or: regulatory) standards are powerful too, but only as long as they are enforced by a competent authority. This chapter will examine the introduction of such a standard in the American context. Three characteristics are noteworthy. First, regulatory standards are almost invariably the result of conflict or disagreement (Busch, 2011). Parties

\footnotetext{
${ }^{230}$ See David (1985) for a classic study on how QWERTY keyboards de-facto became the 'standard' keyboard even though there are alternatives which seem superior from an efficiency standpoint.
} 
often disagree on the goals and effects of regulations vis-à-vis economic or environmental interests. And these presumed interests of actors are not fixed either: they are challenged, negotiated and translated in the rule-making process (Bal, 1999; Halffman, 2003). Second, regulatory standards are typically Janus-faced. On the one hand, they describe 'normal' behaviour for a regulated community. As such, standards rarely refer to the extraordinary; commercial parties should be able to comply with reasonable cost and effort. On the other hand, regulatory standards are typically introduced to spur a change in behaviour too. Precisely because of this double character, standards play an important role in the governance of socio-technical change. Third and related, actors involved in regulatory standard-setting typically draw on various forms of knowledge. They have to make claims about both the present and the future; they have to argue what the world looks like today and what it can (and should) look like after the standard is introduced. To bridge 'is' and 'ought' statements in an authoritative manner, it is necessary to separate techno-scientific knowledge from socio-political considerations (and to subtly link them together).

Scholars in the field of Science and Technology Studies (STS) remind us that this separation is hardly straightforward. One influential strand of research suggests that scientific authority is based on drafting a metaphorical boundary between science and non-science, experts and lay-people, scholars and politicians or between competing scientific disciplines (e.g. Gieryn, 1983; Guston, 2001; Halffman, 2003). Such boundaries are not drawn on the basis of a fixed and unambiguous normative criterion of what counts as 'good science' (as the standard view of science would have it). Rather, what counts as 'good' scientific knowledge is context-dependent and the construction and dispersion of such knowledge involves complicated and intensive social processes (Bijker et al. 2009, p. 27). The processes and practices by which actors gain epistemic authority can be labelled 'boundary work'.

In a landmark article, sociologist of science Thomas Gieryn (1983) for example explains how John Tyndall tried to secure public support for biological studies at the Royal Institution of London in the decades following the publication of Darwin's The Origin of Species in 1859. In Victorian England of the time, the intellectual authority of long-standing religious beliefs still entailed resistance towards the scientific explanation of natural phenomena. Tyndall used public addresses and popular writings to explain to a variety of audiences what progress was being made in the biological sciences. In such speeches, he rhetorically contrasted science to religion in order to attribute certain characteristics. 'Science is practically useful in inspiring technological progress to improve the material conditions of the nation, where religion is merely useful for aid and comfort in emotional matters.' 'Scientific truth is based on experimentation with observable facts of nature, where religious truth is based on spiritual, unseen forces assumed without verification.' 'Science is sceptical in accepting no authority other than facts of nature, where religion is dogmatic in respecting the 
authority of worn-out ideas and their creators.' Such rhetorical attributions helped to demarcate science from religion, it provided a rationale for the intellectual superiority of scientists and it helped to legitimize public funding for the sciences (Ibid.). Gieryn (1994) later distinguished various types of boundary-work. Scientists may claim the unique authority of a particular scientific method (monopolization). Scientists may try to push the boundary of their authority to spaces that were previously claimed by others (expansion). Think of psychologists or anthropologists challenging assumptions about the homo economicus' or of cognitive neuroscientists challenging conventional ideas about good parenting. Scientists may also seek to purify their field from 'non-scientific' practices, like the alleged cherry-picking of specific data by climate sceptics (expulsion). Or scientists may seek to safeguard their resources and shield themselves from interference by e.g. politicians, managers or public opinion (protection of autonomy).

A perspective on boundary work helps to understand how scientists and academic institutes gain epistemic authority. But it can also be used to understand the intricate ways by which policy-advisory bodies like the Dutch Health Council (Bijker et al. 2009) or the IPCC (Guston 2001) or regulatory agencies like the US Environmental Protection Agency gain authority. Such organizations have to make scientific knowledge 'policy relevant', without themselves being accused of political bias. In The Fifth Branch, Jasanoff (1990) studied the changing role of science and politics in the American regulatory process specifically. She countered the prevailing idea that regulations are either (a) purely science/technology-based and therefore legitimate or (b) biased by political interests or agency incompetence and therefore illegitimate. Jasanoff proposed an alternative reading:

"Looking at the substance and context of scientific disputes [or: regulatory debates], it is plausible to conclude that they had relatively little to do with the competence or incompetence of agency officials and a great deal to do with social construction, boundary work, and the politics of scientific knowledge" (Jasanoff, 1990, p. 37).

So, regulatory standards are not simply 'set' in view of unambiguous techno-scientific evidence; they are constructed in a process where the very boundaries between the technical, the scientific, the social and the political are drawn and redrawn (see also Zeiss 2004).

Taking stock, this chapter traces how the US Environmental Protection Agency tried to introduce a $\mathrm{CO}_{2}$ standard. I will argue that EPA had to engage in boundary work in order to legitimize its standard in a credible, authoritative manner. ${ }^{231}$ Sheila Jasanoff $(1987,2002$,

\footnotetext{
231 Scientific or epistemic authority can be defined as "the legitimate power to define, describe, and explain bounded domains of reality" (Gieryn, 1999, p. 1). Importantly, such authority does not exist "as an omnipresent ether, but rather is enacted as people debate (and ultimately decide) where to locate the legitimate jurisdiction over natural facts" (Ibid, p. 15). Under the Clean Air Act, EPA has legal authority to set a regulatory $\mathrm{CO}_{2}$ standard. I
} 
2005) has argued that democracies are characterized by distinct institutionalized and culturally embedded ways of separating science from (and relating it to) politics in law suits, policy-making or public inquiry. In the contentious American context, EPA had to make clear that its standard was purely based on techno-scientific evidence rather than a political agenda. But it was hardly self-evident what counted as evidence of the working of CCS and how such evidence should be interpreted. I will show that EPA engaged in boundary work to legitimize its carbon rule. The Agency tried to show that its rule met the criterion of 'being techno-scientific based' and simultaneously tried to shape this criterion during the regulatory process.

I will understand EPA's boundary work firstly as a rhetorical practice. This means that I will explore in detail how the Agency accounted for its standard in written and verbal communications. But boundary work involves organizational actions too. EPA did not just formulate its standard and despatched it into the world. Instead, it organized several listening sessions with affected parties and consulted specific experts from research institutes, industry and civil society. By acknowledging that viewpoints on the status and future of CCS differed (and by trying to accommodate this difference without choosing sides), EPA tried to justify its regulatory intervention. I will show that EPA also used other organizational means (i.e. direct intervention in the permitting process for a new coal plant) to legitimize its rule. To understand why it was so difficult for EPA to set a stringent standard, I will argue that the Agency had to circumvent what I call 'demonstrator's regress'.

\subsection{RESEARCH DESIGN}

This chapter is based on a multi-level research design. It traces the actions of EPA on anthropogenic climate change, focusing on its efforts to introduce a $\mathrm{CO}_{2}$ standard for new coal-fired power plants at the federal level. There is an extensive record of public comments, minutes of meetings and regulatory considerations publicly available online. ${ }^{232}$ Such documents provide insight in the viewpoints of affected parties (e.g. the power sector and the environmental community) and the role of evidence in the standard-setting procedure. Documents are supplemented with semi-structured interviews conducted during fieldwork in the US from May to July 2013. My analysis at the federal level is supplemented with an analysis of EPA's actions in Illinois. This State aims to be a national and international

take it that the Agency has to engage in boundary work to secure its epistemic authority when giving substance to this legal obligation.

${ }^{232}$ See for example: www.epa.gov and www.federalregister.gov. 
frontrunner on CCS implementation. ${ }^{233}$ My analysis focuses on regulatory debates which surrounded the Taylorville Energy Center (TEC). Few would question the feasibility of CCS for this new coal plant. Nevertheless, the project triggered a fierce debate on, amongst others, the feasibility of CCS. Both Illinois-EPA and EPA played an important role in settling this debate. As such, the case provides an excellent opportunity to study the multilevel boundary work of EPA as it tried to legitimize its federal carbon standard.

In terms of narrative, this chapter is chronologically structured. Section 4.3 sketches the political context which gave EPA legal authority to take climate action (1980s - 2009). Section 4.4 explores how EPA tried to determine a 'normal' $\mathrm{CO}_{2}$ emissions profile for new coal plants $(2009$ - 2012). Section 4.5 focuses on EPA's intervention in the regulatory process surrounding a new clean coal plant in Illinois (2005 - 2013). Section 4.6 will return to the federal level. EPA was forced to revoke its proposed standard and drafted a revised version in light of fierce legal, political and scientific scrutiny (2012 - 2015). The standard-setting process is lengthy, complex and often highly technical. To prevent that the reader loses track of the multi-level developments, an overview is provided in Appendix C. The arrows indicate when events at the federal and state level were directly related.

A caution regarding my use of words is warranted. In the American context, policy papers on CCS commonly speak of 'clean coal.' The precise meaning of this term is notoriously vague and contested (Fitzgerald, 2012). It was first adopted by the American power sector in the 1980s, when the Clean Air Act started to push emission control technologies for coal usage (i.e. limiting $\mathrm{SO}_{2}$ and $\mathrm{NOx}$ emissions). In later years, global warming became a public relations disaster for the fossil fuel industry. In turn, 'clean coal' started to suggest low(er) $\mathrm{CO}_{2}$ emissions too. Many environmental NGOs dismiss the term as an oxymoron, because the extraction and use of coal continues to have a harmful environmental impact, i.e. through mountaintop removal or because coal ash pollutes rivers (Ibid.). In this chapter, I will use the term 'clean coal' to refer to technologies for linking CCS to coal-fired power plants, as this has become common in American policy discourse. However, I do not want to suggest that clean coal technologies are without negative environmental impact.

Since the previous two chapters have focused on the Dutch context, section 4.3 will briefly introduce the American context. I will sketch how CCS has emerged on the American policy agenda and how EPA became legally obliged to regulate $\mathrm{CO}_{2}$ emissions.

\footnotetext{
233 The US approach towards climate change has traditionally been characterized by stagnating environmental federalism (Rabe, 2008). In turn, the onus of American climate action has shifted to the regional, state and local level (Lutsey \& Sperling, 2008; Stephens, 2009, p. 28). The implementation of CCS is therefore governed by developments at the State level too (Wilson, Stephens, Rai Peterson, \& Fischlein, 2009). In 2008, Illinois was the first State to introduce a Clean Coal Portfolio Standard to incentivize CCS development. So, it provides a context where the dominant discourse on the 'feasibility' of linking CCS to commercial-scale power plants seemed most convincing.
} 


\subsection{REGULATING THE AMERICAN AIR}

In 1963, US Congress passed the influential Clean Air Act. This stimulated the development of emission control technologies like flue gas desulphurization systems (so-called 'sulphur scrubbers'), in order to reduce pollution stemming from large sources like power plants and steel mills. Towards the end of the 1960s, public enthusiasm for environmental protection only grew (Mitchell, 1989; Dunlap \& Mertig, 1992). Post-war economic growth had created affluence, which allowed for lower materialistic concerns and greater concern over the quality of life. Scientific knowledge about environmental problems began to grow. Publications by authors like Rachel Carson, David Brower and Paul and Anne Ehrlich had captured the imagination of the American public: their books underlined both the natural beauty of ecosystems and their vulnerability to human infliction (e.g. the use of DDT and other pesticides to increase food production). In this context, conservation organizations like the Sierra Club and the Environmental Defense Fund started to address a wider range of environmental issues (Dunlap \& Mertig, 1992). Other environmental organizations were founded too, like the National Resources Defense Council in 1970. On April 22 1970, the environmental spirit culminated in Earth Day. Roughly 20 million Americans, Republicans and Democrats alike, participated in this national demonstration, which made clear that environmental protection should be high on the political agenda. In the same year, Congress passed ambitious amendments to the Clean Air Act.

With these 1970 amendments, standards came to play a key role in environmental protection. National Ambient Air Quality Standards (NAAQS) were introduced to limit the concentration of wide-spread pollutants: carbon monoxide, lead, nitrogen dioxide, ozone, particulate matter and sulphur dioxide. NAAQS protect public health in general, whilst also differentiating for specific risk populations like children, elderly people or those suffering from asthmatics. Besides ambient air quality standards, New Source Performance Standards (NSPS) were introduced to limit pollution at the source. NSPS apply to major sources of air pollution, like power plants, oil refineries, steel mills and factories producing glass, concrete or rubber tires. New sources have to obtain a construction permit. This permit is only granted when the facility meets the relevant performance standards. Additionally, the facility has to be equipped with the Best Available Control Technology (BACT). BACT is established on a case-by-case basis, taking the costs and energy penalty of installing abatement tools into account. In the contemporary debate on CCS, central to this chapter, parties fiercely disagree on what is an adequate performance standard and whether or not CCS qualifies as BACT for new coal-fired power plants.

The Environmental Protection Agency (EPA) plays a key role in settling such disputes. This federal Agency, established in 1970 too, is responsible for setting standards and moni- 
toring compliance under the Clean Air Act. By 1990, Congress provided EPA with broader authority to implement and enforce regulations. A program was for example established to phase out chemicals which cause depletion of the ozone layer and the acid rain program promoted innovative technologies to clean $\mathrm{SO}_{2}$ emissions associated with coal use. At the same time, increased emphasis was given to the cost-effectiveness of regulations, where EPA was urged to adopt market-based standards. This means that standards should not be 'technology-forcing'. Instead, commercial parties should be free to decide for themselves how they wanted to meet the standard, using technologies which are (or soon will become) available in the market place.

Public accountability came to play an important role too. The 1990 amendments to the Clean Air Act ensure that members of the public can comment on EPA's decisions. In case of major rulings (like proposed NSPS), the Agency holds hearings in varies cities across the country and asks for written comments. The public can help review construction permits and can ask EPA to take action against polluters in case of non-compliance. Public involvement and transparency have become crucial to safeguard EPA's epistemic authority. At the same time, it is emphasized that regulations and standards are science- and technology-based, rather than political interventions. ${ }^{234}$ EPA periodically reviews the science upon which its standards are based and updates the standard themselves (NSPS are for example updated every 8 years). This is not to say that political developments do not affect the work of the Agency too. This becomes clear when looking at EPA's actions on one pollutant in particular: $\mathrm{CO}_{2}$. Regulatory action on $\mathrm{CO}_{2}$ was heavily curtailed by political opportunities, as the next section will make clear.

\subsubsection{Climate politics and the promise of CCS}

The American climate approach has changed considerably over the years. In 1992, the US signed the UNFCCC Rio declaration, a non-binding (!) agreement to reduce national GHG emissions. The event was heralded as a victory for the environmental community. In the same period, an anti-environmentalist countermovement started to emerge in the US, spearheaded by the fossil fuel industry, its business allies and conservative think tanks and politicians (McCright \& Dunlap, 2011, p. 158). This movement effectively worked to debunk the scientific evidence for climate change and thus undermined the legitimacy of domestic climate action, be it in the form of a carbon tax, a cap-and-trade system, binding reduction targets or regulatory measures (Ibid.; see also Oreskes \& Conway, 2004). Early

\footnotetext{
${ }^{234}$ EPA itself does not conduct scientific research. The Agency and its Scientific Advisory Board focus on reviewing the way that knowledge is produced by other actors (Jasanoff, 1990).
} 
1990s is also the period that the US started to make substantial public funding available for research and demonstration of CCS (Stephens, 2009, p. 27).

In 1997, President Bill Clinton signed the Kyoto Protocol, which included binding targets for reducing GHG emissions. However, Clinton never submitted this Protocol to the Senate for ratification. He knew that it would fail, as the Senate had earlier (by bipartisan vote of 95 to 0 ) expressed its opinion that the US should not participate in an agreement that would limit domestic GHG emissions without also limiting emissions from developing countries (Hammit, 2011, p. 170). Opposition to binding climate action continued during the George W. Bush Administration. Insiders of the Administration engaged in a wide range of practices to debunk climate science (McCright \& Dunlap, 2011, p. 159). Again, this does not mean that no political incentive was given to mitigate climate change. The focus was simply on voluntary technological innovation instead of binding federal action that could harm the fossil fuel industry or the American economy at large. One could even say that CCS has been pursued in the US as an alternative to the Kyoto Protocol's climate approach (Gjefsen, 2013, p. 75).

Large-scale implementation of CCS promised to allow for continued use of domestic coal reserves. Coal has traditionally played an important role in the American economy. Coal is relatively easy to mine, transport and store and is therefore a cheap source of energy. ${ }^{235}$ Supplies are abundant. The US soil holds an estimated 238 billion tons of coal, equivalent to $29 \%$ of the proven coal reserve of the entire world. Most of the recovered coal is used in the power sector. Between 40 to $45 \%$ of all American electricity is generated by coal-fired power plants. Those facilities account for roughly a third of the total $\mathrm{CO}_{2}$ emissions attributable to human activities in the entire United States. Besides abundant coal reserves, the American underground also provides ample storage space for $\mathrm{CO}_{2}$. Experts from the National Energy Technology Laboratory (NETL) estimate that around 2.400 Gton of $\mathrm{CO}_{2}$ can safely be injected underneath North America. With roughly 6 Gton of $\mathrm{CO}_{2}$ produced in the US per year from large sources, this translates into 'hundreds of years of storage potential. ${ }^{236}$

Under the Bush Administration (2001 - 2009), CCS became a key element of the American climate approach. In 2002, the Clean Coal Power Initiative was initiated under auspices of DOE/NETL. This Initiative aimed to demonstrate CCS and drive down the costs involved. ${ }^{237}$ And in February 2003, \$1 billion in public funding was made available to

\footnotetext{
${ }^{235}$ Environmental organizations emphasize that coal usage is only 'cheap' as long as externalities (e.g. the impact of coal burning on global warming or of coal mining on the environment) are not included in the price of coal. ${ }^{236}$ Source: DOE/NETL. (2007). Carbon Sequestration Atlas of the United States and Canada. Albany (OR): US Department of Energy; National Energy Technology Laboratory.

${ }^{237}$ For more on these initiatives, see Figueroa, Fout, Plasynski, McIlvried \& Srivastava (2008).
} 
create the world's first zero-emission electricity/hydrogen plant, called FutureGen. At the time, this CCS demonstration project was the cornerstone of the Bush Administration's climate program (Stephens, 2009, p. 30).

Importantly, not everyone was convinced that a voluntary, technology-driven climate strategy sufficed. ${ }^{238}$ Already in 1999, several parties had engaged in litigation to force EPA to treat $\mathrm{CO}_{2}$ as a regulated pollutant. In 2003, the Agency answered this petition with a firm 'no.' EPA argued that GHGs provided a poor fit with the Clean Air Act, which was originally designed with pollutants like sulphur dioxide and mercury in mind (having more direct, more clear-cut and more local cause-effect-relations with public health). EPA considered it unwise to undertake unilateral action in a time when a causal link between GHGs and the increase in global surface air temperatures was not unequivocally established (Lutsey \& Sperling, 2008, p. 673). Scientific uncertainty was thus presented as a reason for regulatory inaction. But climate science developed over time. In a landmark ruling of 2007, the US Supreme Court dismissed EPA's earlier reference to scientific uncertainty. As one of the judges put it, the burden of proof was on the federal Agency:

"Under the clear terms of the Clean Air Act, EPA can avoid taking further action only if it determines that GHGs do not contribute to climate change or if it provides some reasonable explanation as to why it cannot or will not exercise its discretion to determine whether they do" (Massachusetts $v$. Environmental Protection Agen$c y, 415$ F. 3d 50)

This ruling did not oblige EPA to issue a so-called 'Endangerment Finding' on GHGs, nor did it prescribe what measures the Agency should to take in case of such a finding. EPA was merely forced to "ground its reasons for action or inaction in the statute" (Folger, 2013a, p. 14). After the Supreme Court's ruling, EPA drafted standards to curb GHG emissions from motor vehicles, which effectively constituted an Endangerment Finding. By December 2007, this regulatory package was send to the White House Office of Management and Budget (OMB) for review. But this Office refused to upload the agencies' materials and thus stalled White House clearance of the standards (Heinzerling, 2012). In doing so, EPA's regulatory climate action came to a halt under the Bush Administration. ${ }^{239}$

\footnotetext{
${ }^{238}$ In a commentary of 2008, Heleen de Coninck (editor of IPCC's Special Report on CCS) argued for example: "The United States is the largest contributor to CCS research, but its budget so far has been spent on relatively small-scale CCS demonstrations. It has failed initiating efforts to seriously commercialize CCS” (de Coninck, 2008 , p. 2). This has arguably changed under the Obama Administration, as I will explain in the remainder of this chapter.

${ }^{239}$ Epistemic uncertainties on global warming were gradually reduced. For regulatory action though, they did not have to be taken away completely. Wiener et al. (2011) emphasize that the Clean Air Act allows for anticipatory regulation of uncertain risks too. In fact, EPA has routinely legitimized the introduction of new and more stringent air quality standards as being 'precautionary' (Ibid, p.10).
} 
To understand such political obstruction, one should be aware of the far-reaching implications that EPA's Endangerment Finding could have for the American power sector and, potentially, the economy as a whole. Regulating $\mathrm{CO}_{2}$ in one instance (i.e. motor vehicles) would trigger permitting requirements for a host of other $\mathrm{CO}_{2}$ producers too, like power plants and heavy industry. ${ }^{240}$ So, the science-based Endangerment Finding constituted political dynamite.

EPA's leeway for regulating GHGs changed with the inauguration of Barack Obama as $44^{\text {th }}$ President of the US in 2009. Obama struggled to garner bipartisan support for meaningful political action on climate change. ${ }^{241}$ So, the Obama Administration pushed for regulatory climate action instead. In December 2009, EPA published its long awaited Endangerment Finding. ${ }^{242}$ But regulating GHGs was not an easy task. Despite significant advances in climate science, there remained major challenges in issuing National Ambient Air Quality Standards. ${ }^{243}$ Greenhouse gases disperse from sources throughout the world. They are pollutants with long atmospheric lifetimes. Ambient air concentrations are not higher in areas with many emissions sources compared to areas with fewer sources. And it was difficult to determine which GHG concentrations would suffice to protect public health and the environment. So, EPA decided not to introduce NAAQS for $\mathrm{CO}_{2}$. Instead, it tried to reduce domestic $\mathrm{CO}_{2}$ emissions via (amongst others) a performance standard for new power plants. The rest of this chapter is dedicated to exploring how EPA tried to put this particular standard in place.

\footnotetext{
240 Theoretically, all producers of $\mathrm{CO}_{2}$ (large or small) could be affected. Some feared therefore that an Endangerment Finding on $\mathrm{CO}_{2}$ would lead to a cascade of climate regulations.

${ }^{241}$ Obama's preferred cap-and-trade legislation (H.R.2454, American Clean Energy and Security Act, also known as the 'Waxman Markey Bill) passed the House in June 2009 (with 219 to 212) but later died in Senate.

${ }^{242}$ Journalists had long urged EPA through the Freedom of Information Act to make its draft report on the Endangerment Finding publicly available. The Agency had always refused to do so during the Bush Administration. It finally released the $2007 \mathrm{draft}$ in October 2009. According to an EPA spokeswoman, the draft "demonstrates that in 2007 the science was as clear as it is today [and] the conclusions reached then by EPA scientists should have been made public and should have been considered" (quoted in: Samuelsohn, S. \& Bravender, R. (2009). EPA Releases Bush-Era Endangerment Document. The New York Times, October 13, 2009. Available at http://www.nytimes.com/gwire/2009/10/13/13greenwire-epa-releases-bush-era-endangerment-document47439.html, archived under http://www.webcitation.org/6VM44EBdT). This turn of events illustrates that the actions of the EPA, although science- and technology-based, are heavily curtailed by the (changing) political climate in the US.

243 See: EPA. (2008). 'Regulating Greenhouse Gas Emissions under the Clean Air Act - Advance Notice of Proposed Rulemaking'. Environmental Protection Agency, EPA-HQ-OAR-2008-0318, July 2008.
} 


\subsection{DETERMINING A 'NORMAL’ EMISSION PROFILE}

EPA had to navigate between several poles when issuing a $\mathrm{CO}_{2}$ standard for new power plants. Section $111 \mathrm{~b}$ of the Clean Air Act requires the Agency to identify the best system of emissions reduction that is "adequately demonstrated." Four factors are taken into account: (i) is the system technically feasible, (ii) are the costs reasonable, (iii) what are the emission reductions and (iv) does the system promote technology development? These factors obviously invite several meta-questions too: What does it mean for an emission control technology to be 'adequately demonstrated'? And what proof or evidence can be given to establish this?

EPA's interpretation would surely invite legal opposition. ${ }^{244}$ To increase the chance that its standard would be upheld by the Supreme Court, the Agency organized several Listening Sessions in February and March 2011. ${ }^{245}$ These consisted of round table discussions with three broad groups: the energy sector (utilities, coal companies, and power suppliers), the environmental community and State-level regulatory agencies were subsequently invited. All sessions ended with a short period of time where members of the public could provide comments. So, although EPA claimed that its standard was based on techno-scientific evidence, this did not mean that it acted in an autocratic manner. Listening sessions helped to collect different viewpoints on the status and future of CCS. In the following, I will discuss the main issues and concerns that were raised during these sessions.

EPA's standard was meant to provide much needed certainty to the regulated community. ${ }^{246}$ Although ultimately tied to the Clean Air Act, EPA had considerable flexibility in

\footnotetext{
${ }^{244} \mathrm{EPA}$ officials expected industry to oppose regulations, like they had opposed NSPS for $\mathrm{SO}_{2}$ in 1979. This standard had mandated the elimination of 70 to $90 \%$ of a new coal plant's $\mathrm{SO}_{2}$ emissions and effectively forced the use of sulphur scrubber technologies. Industry claimed that this standard would be detrimental to the coal industry, as it would require an investment of billions of dollars in a technology that was not considered 'adequately demonstrated' yet (see e.g. Randle, 1979). Do note that the analogy between sulphur scrubbers and CCS is controversial (as is any statement on the status and future of CCS in the context of EPA's standard-setting process). Critics emphasize that CCS is hardly a simple 'add-on technology'.

${ }^{245}$ Recordings of these Sessions are available at http://www.ustream.tv/recorded/12457383 and http://www.ustream.tv/recorded/12714653. Public listening sessions (broadcasted live through web-feeds) were arguably meant to ensure the epistemic authority of EPA too, whilst operating in a highly adversarial environment: the American power sector.

${ }^{246}$ Indeed, regulatory uncertainty has often been described as a significant barrier for the commercialization of CCS. See for example: "Perhaps the most important thing Congress could do to facilitate the development of [CCS] projects is to provide regulatory certainty... Without regulatory certainty, the financial markets will remain reluctant to provide necessary project financing, or the financing they do provide will remain at a very high cost, stifling investment in CCS deployment". Source: Tenaska. (2009). Testimony of Dr. Gregory P. Kunkel, PhD, Vice President of Environmental Affairs, Tenaska, Inc. US House of Representatives, Committee on Energy and Commerce, Subcommittee on Energy and the Environment.
} 
setting standards. It for example had to decide upon their form. The Agency envisaged a standard in terms of $\mathrm{lbs} \mathrm{CO}_{2} / \mathrm{MWh}$, but it was up for debate whether this should be met at any given moment in time or whether facilities would be allowed to meet it on average (e.g. in a 12 -month period or over their lifetime of roughly 30 years). Additionally, EPA had to decide to which classes, types and sizes the standard would apply. After all, pulverized coal plants, coal gasification plants and natural gas plants all have different emission profiles. Adding (partial) CCS to commercial-scale power plants not only changes this profile, but also their overall cost and performance (Rubin, Chen, \& Rao, 2007).

A crucial question was how 'aggressive' the standard should be. EPA was in a tough spot here. The Agency stressed that it would not (nor could) determine the amount of $\mathrm{CO}_{2}$ emission reductions that should be achieved domestically. Instead, the performance standard was meant to simply 'level the playing field' in the power sector. The typology of standards offered by Lawrence Busch (2011) can be used to reformulate this. EPA's standard was meant to act as a filter: it would ensure that all new coal plants have at least a 'normal' emission profile. The BACT requirement added an Olympic standard: it forced individual companies to further minimize their $\mathrm{CO}_{2}$ emissions in the most cost-effective manner. How to do this would have to be assessed on a case-by-case basis. The power sector responded positively to EPA's explanation. Industry representatives argued that NSPS had traditionally been market-based without actually forcing the use of one particular technology. And practical experience with demonstration projects was presented as evidence that companies faced considerable challenges when trying to scale-up CCS to the size of a commercial power plant. ${ }^{247}$ In turn, CCS was not considered a 'normal' control technology (yet) and could therefore not be used to legitimize an overly aggressive standard.

The vision of NSPS as a non-dramatic, easily achievable baseline pleased the power sector. However, it was heavily criticized by environmental NGOs during EPA's second Listening Session. A representative of the Sierra Club argued for example that a more aggressive standard was essential to mitigate climate change:

"While EPA was reluctant to put stringent limits on sources, a more assertive approach is needed. More needs to be done than bringing laggards up to the level of mediocrity." 248

Other environmental groups agreed. The Clean Air Task Force (CATF) for example is a non-profit organization that aims to reduce the environmental impact of fossil fuel usage. According to CATF, it will be difficult (if not impossible) to mitigate climate change with-

\footnotetext{
247 See also Herzog (2009, p. 282).

${ }^{248}$ EPA (2011). Listening Session on GHG Standards for Fossil-Fuel Fired Power Plants. Session 2: Environmental and Environmental Justice Organizations, February 152011.
} 
out global use of CCS. ${ }^{249}$ During EPA's Listening Session, the CATF Director argued that a stringent performance standard could "be met by existing technologies today, especially CCS, which has been demonstrated as a technology." 250

In support of this claim, environmental groups emphasized several things. Enhanced oil recovery (EOR) has been in commercial use since the 1970s. In Texas alone, over 1 billion tons of $\mathrm{CO}_{2}$ has been used for EOR. There is over 3600 miles of $\mathrm{CO}_{2}$ pipeline in place in the US. Demonstration projects were injecting $\mathrm{CO}_{2}$ in aquifers underneath e.g. the North Sea, Algeria and Illinois. And $\mathrm{CO}_{2}$ capture was already in commercial use in California, Massachusetts and Sardinia (Italy). In West-Virginia, a pilot project captured roughly 200 ton of $\mathrm{CO}_{2}$ /day from the Mountaineer plant (emitting over 8.5 $\mathrm{Mt} \mathrm{CO}_{2} /$ year). The owner of this plant, American Electric Power, expected that this could be scaled-up to commercial-size by 2015 with financial support from the Department of Energy. ${ }^{251}$ Finally, various clean coal plants were in the permitting phase in Mississippi, Indiana, Kentucky, Texas and Illinois. All promised to capture and sequester a substantial part of their $\mathrm{CO}_{2}$ emissions. Such promises were presented as evidence that CCS was technically feasible and adequately demonstrated throughout the world. A representative of the Sierra Club concluded therefore:

"NSPS is relying on technology which is already out there: but demonstrated does not mean wide-spread. It can be demonstrated, but not necessarily in the US. So the Agency has room to adopt strict standards."252

Whereas industrial groups emphasized the uncertainties involved in commercial-scale CCS (e.g. in terms of power plant performance and associated costs), environmental groups felt that the uncertainties were sufficiently taken away. ${ }^{253}$ Put differently: both sides acknowl-

\footnotetext{
${ }^{249}$ See e.g. Clean Air Task Force. (2012). Written Testimony of John Thompson, Director of Fossil Transition Project, CATF on "American Energy Initiative" (HR6172). US House of Representatives, Committee on Energy and Commerce, Subcommittee on Energy and Power.

${ }^{250}$ EPA (2011). Listening Session on GHG Standards for Fossil-Fuel Fired Power Plants. Session 2: Environmental and Environmental Justice Organizations, February 152011.

251 This project was cancelled in 2013. American Electric Power feared that state regulators would not allow them to recover its costs for the $\$ 668$ million project by charging customers. The company therefore saw no compelling regulatory or economic reason to apply large-scale CCS to the 31-year old power plant. See: Wald, M., \& Broder, J. (2011, July 13). Utility Shelves Ambitious Plan to Limit Carbon. The New York Times. Retrieved from http://www.nytimes.com/2011/07/14/business/energy-environment/utility-shelves-plan-to-capture-carbondioxide.html, archived under http://www.webcitation.org/6dfm2Jb5B. I will return to this cancellation of US demonstration projects in Section 4.6.

252 EPA (2011). Listening Session on GHG Standards for Fossil-Fuel Fired Power Plants. Session 2: Environmental and Environmental Justice Organizations, February 152011.

${ }^{253}$ The same difference of opinion had earlier split industrial and environmental groups who participated in EPA's 'Advanced Coal Technology Working Group'. Source: Letter by NRDC and CATF (September 12, 2007). 'Concerns of NRDC and CATF regarding the Advanced Coal Technology Work Group to the Clean Air Act Advisory Committee, and the Work Group's Six Month Interim Report', p.3.
} 
edged that EPA's standard should be based on 'adequately demonstrated' control technologies, but only environmental groups felt that CCS qualified as such. ${ }^{254}$

It was not easy for EPA to say which side was right. In a third Listening Session, EPA called for input from States and other regulatory agencies on how aggressive its standard should be. Some States were of the opinion that EPA should take the lead in identifying CCS as "commercially demonstrated." But there was a challenge. As the representative of the National Association of Clean Air Agencies pointed out:

"To really get CCS up and running, there is a need for more funding [to create economies of scale and drive down development costs]. EPA cannot give that through NSPS, so our concern is: given the current financial situation, how do we think creatively about getting CCS running? Because the ultimate only way to reduce $\mathrm{CO}_{2}$ emissions from coal-fired power plants is coal gasification and CCS, or some other miracle technology has to appear. So we need this to work." 255

So, the promise of CCS was acknowledged, but it was also clear that the development of $\mathrm{CO}_{2}$ capture technologies and of infrastructures for large-scale $\mathrm{CO}_{2}$ storage (to the level where it would have a substantial impact on climate change) required a substantial economic investment. In absence of a carbon tax or a cap-and-trade system, few commercial parties would be willing to make this investment. EPA therefore considered a two-phased approach, where its standard would initially be based "on a more traditional approach of looking at which technologies are available," and then a second one that would "try to set a goal for technology development." ${ }^{256}$ In 2012, this approach took the following form.

Gas plants produce roughly half as much $\mathrm{CO}_{2}$ emissions as coal-fired power plants. Some environmental groups described them therefore as 'the gold standard.'257 In April 2012, EPA qualified gas plants as the best system of emission reduction for electricity gen-

\footnotetext{
${ }^{254}$ In his key note speech at NETL's CCS R\&D Review meeting, George Peridas (Chief Scientist of NRDC) stated for example: "I don't think that it's EPA's job to pick technologies, and they are not doing that. What EPA did...was to stay technology neutral... Gas could qualify and coal could also qualify. CCS isn't something that the proposed rule mandates, but it's a compliance option which people may choose, and I think that's the way to go". Available at: http://ghgnews.com/index.cfm/qa-nrdce28099s-george-peridas/, archived under: http://www.webcitation.org/6YXZbEH2S.

${ }^{255}$ EPA (2011). Listening Session on GHG Standards for Fossil-Fuel Fired Power Plants. Session 3: State and Tribal Representatives, February 172011.

256 Ibid.

${ }^{257}$ See for example: Eilperin, J. (2013, March 15). EPA may delay climate rules for new power plants. The Washington Post. Retrieved from http://www.washingtonpost.com/politics/epa-may-delay-climate-rules-for-new-powerplants/2013/03/15/28e9d37e-8cda-11e2-b63f-f53fb9f2fcb4_story.html?hpid=z1, archived under http://www.webcitation.org/6dflw0MAm. A similar standard has been proposed by environmental groups in the Dutch context. See: Green4Sure. (2007). Het groene energieplan voor Nederland. ABVAKABO, FNV, Greenpeace, Milieudefensie, Stichting Natuur en Milieu, Wereld Natuur Fonds.
} 
eration. If commercial parties wanted to build coal plant instead, these should operate at the same level as a gas plant. And according to EPA, this could be achieved by (partially) employing CCS. The proposed standard allowed for an 'averaging option' too: operators could either sequester roughly $50 \%$ of their $\mathrm{CO}_{2}$ from the start or they could achieve it on average over a 30-year period. This averaging option was meant to ease concerns over the remaining economic, regulatory and technical uncertainties involved in commercial-scale CCS. ${ }^{258}$

\subsubsection{Turning expectations into evidence}

Phrasing its standard in this manner can be seen as a form of boundary work. EPA provided evidence to show that CCS met the criteria of being 'technically feasible' and 'adequately demonstrated'. EPA simultaneously shaped these criteria in the standard-setting process. Listening sessions made clear that there remained uncertainties in commercial-scale CCS and that the technologies involved were not demonstrated at commercial-scale yet. But since new coal plants would only have to sequester half of their $\mathrm{CO}_{2}$ emissions, it was no longer needed to give 'full' and final evidence on the functioning of CCS. Put differently, EPA acknowledged that evidence on the economic and technical feasibility of CCS was not conclusive yet. However, the Agency maintained that enough was known for new coal plants to sequester roughly $50 \%$ of their emissions (thus meeting the 'gold standard' of a gas-fired power plant). Adding a 30-year averaging option allowed EPA to also mobilize different evidence in support of its standard. EPA acknowledged that commercial-scale CCS was not demonstrated at the time. However, it could now point to evidence suggesting that CCS would become 'adequately demonstrated' in the decades to come. This latter move meant that EPA pre-empted the outcome of future demonstration projects. It was based on the expectation that such projects would successfully demonstrate CCS in the future.

The averaging option raised a difficult question in the context of litigation: does the Clean Air Act allow expectations of future technology development as evidence that CCS is adequately demonstrated at the time the standard is introduced? EPA felt that it did. The Agency referred to a Senate Committee Report on 1970 Clean Air Act Amendments which

\footnotetext{
${ }^{258}$ Large-scale $\mathrm{CO}_{2}$ storage invites numerous legal questions, e.g. regarding pore space ownership, liability and criterions for (abandoning) injection wells. Many of these issues were not yet settled when EPA started deliberations on its performance standard. For more on the regulatory uncertainties that were perceived at the time, see (Wilson, Friedmann, \& Pollak, 2007; Vann \& Parfomak, 2008; Stenhouse, Gale, \& Zhou, 2009).
} 
states that anticipations of future developments may be used to determine an emission reduction system as 'adequately demonstrated':

"The term 'available control technology' is intended to mean that the Secretary should examine the degree of emission control that has been or can be achieved through the application of technology which is available or normally can be made available. This does not mean that the technology must be in actual, routine use somewhere. It does mean that the technology must be available at a cost and at a time which the Secretary determines to be reasonable." 259

EPA thus asserted that it could "reasonably project the path of technological development" when issuing a $\mathrm{CO}_{2}$ standard with a 30-year averaging option. ${ }^{260}$

EPA was not allowed to base a rule on mere "crystal ball' inquiry". ${ }^{261}$ So the Agency conducted an extensive review of economic studies, technology roadmaps and policy advisory reports. These included for example the 2010 Report of Obama's Interagency Task Force on CCS. ${ }^{262}$ This influential study acknowledged that early CCS projects faced economic challenges due to uncertain climate policies, first-of-a kind technology risks and the high costs of CCS. However, the report also stressed that there were no insurmountable technological barriers that prevented commercial-scale application in the future. The Task Force advised that 5 to 10 demonstration projects should be brought online by 2016, supported by DOE/NETL. ${ }^{263}$ And indeed, President Obama had made billions of dollars available for this under the 2009 American Recovery and Reinvestment Act. The underlying philosophy was that demonstration projects would move CCS through the remaining stages of 'Technology Readiness.' ${ }^{264}$ DOE/NETL uses a nine-step scale, ranging from basic science level [1] to commercially available [9]. Most CCS technologies were considered to be somewhere in the demonstration stage $[6-8] .{ }^{265}$ To reach the final stage, learning-by-

\footnotetext{
${ }^{259}$ EPA (April 13, 2012), 'Standards of Performance for Greenhouse Gas Emissions for New Stationary Sources; Electric Utility Generating Units; Proposed Rule', Federal Register, vol. 77, no. 72, p. 22419, italics added. 260 Ibid.

261 Ibid.

${ }^{262}$ Source: ITCCS. (2010). Report of the Interagency Task Force on CCS. Interagency Task Force on CCS, August 2010.

${ }^{263}$ Ibid. Roadmaps provided by the coal industry typically stressed that the federal government had a crucial responsibility in advancing CCS and called for continued funding of CCS demonstration projects. See for example: The Coal Based Generation Stakeholder Group (2005). A vision for achieving ultra-low emissions from coalfueled electric generation, p.5. or: National Coal Council (2006). Coal: America's energy future, March 2006. ${ }^{264}$ DOE. (2009). Technology Readiness Assessment Guide. Washington DC: US Department of Energy, nr. DOE 413.3-4. See also: Global CCS Institute (2012). Technology options for $\mathrm{CO}_{2}$ capture. Canberra: Global Carbon Capture and Storage Institute, p.5-6.

${ }^{265}$ Interview with Michael Knaggs, Program Director of DOE/NETL's Office of Major Demonstrations, July 2013. See also the Testimony given by Scott Klara (Deputy Laboratory Director of DOE/NETL) on May 12, 2011 for
} 
doing was considered crucial. Innovation literature suggested that this would help to drive down costs. ${ }^{266}$ EPA presented such studies (and the existence of governmental R\&D funding schemes) as evidence that CCS would become a normal abatement tool in the decades to come.

EPA provided a lot of evidence on the status and future of CCS. At the same time, the Agency stressed that it was not legally obliged to do so. After all, EPA had determined that gas-fired power plants were the 'gold standard' for electricity generation. So why was evidence on CCS included at all? This was arguably done to avoid the accusation that EPA had a political agenda: forcing coal out of the American energy mix. If coal plants were being phased-out, it should be due to market forces, not due to EPA's regulatory standard.

\subsubsection{Governing future CCS development}

Let us now return to the central question of this chapter: how did EPA try to legitimize a stringent $\mathrm{CO}_{2}$ standard? The Agency suggested that a gas plant was the 'gold standard' for electricity production. EPA included a 30-year compliance option for those parties wanting to build a coal plant instead. Although not legally required to do so, EPA pointed to R\&D funding schemes and economic studies as evidence that CCS would (also without the standard!) become adequately demonstrated in the near future.

Promises of technological development and future cost reductions are well-known phenomenon in the sociology of expectations (van Lente, 1993; N. Brown \& Michael, 2003). Such promises serve to mobilize actors and to attract public funding. They can thereby result in a self-fulfilling prophecy. But empirical studies have shown that early expectations often turn out to be grossly exaggerated (Junginger, Suurs, Verbong, \& Schaeffer, 2010, p. 43). This may result in a 'hype and disappointment dynamic,' where initial positive assessments of a technology's future are followed by an unexpectedly slow implementation (Borup, Brown, Konrad, \& Van Lente, 2006; Russell et al., 2011, p. 660). EPA was well aware of this possibility. ${ }^{267}$ In fact, the 30 -year compliance option was meant to prevent this dy-

the Senate Committee on Energy and Natural Resources, expressing the viewpoint that commercial-scale CCS demonstration project projects (like FutureGen) were needed to reach the final stage of technology readiness.

${ }^{266}$ See e.g. (Rubin et al., 2004; Hamilton, Herzog, \& Parsons, 2009; van den Broek et al., 2009).

${ }^{267}$ Already in the 1970s, EPA had tried to introduce standards to reduce CO and NOx pollution from new cars

(Rip \& Kemp, 1998, pp. 375-6). The automobile industry criticized these technology-forcing standards for being overly restrictive. They half-heartedly engaged in research and development of low-emission engines, expecting that the law would not be rigorously enforced upon them if they failed to develop compliance technologies. They were right: the standards were postponed by EPA in 1973 and 1975 and by Congress in 1974 and 1977. In case of 
namic from occurring. It both predicted and prescribed a time-span in which the economic costs of CCS would (and should) be sufficiently reduced and the technical working adequately demonstrated.

Importantly, EPA did more than adding techno-scientific evidence on the status and future of CCS. The Agency also tried to suggest that some uncertainties were normal in technology development. EPA recognized for example that the exact costs of commercialscale CCS were difficult to scientifically predict. But when proposing its standard, EPA added that economic uncertainty was normal for parties operating in a volatile energy market:

"The presence of cost uncertainty by itself does not mean that prospective power plants cannot be expected to adopt the 30-year averaging compliance option. We note that prospective power plants face significant cost uncertainties in any event." $^{268}$

EPA added market surveys to show that commercial parties were not expected to invest in new coal plants anyway (besides those receiving public funding to set-up CCS demonstration projects), due to the availability of cheap shale gas. So even if the proposed standard would add some economic uncertainty to the business case for coal, EPA suggested that this was irrelevant in view of much larger uncertainties caused by market fluctuations.

Besides such rhetorical positioning, EPA also used direct intervention to legitimize its regulatory standard. To understand this form of boundary work, it is instructive to look at the permitting process for a clean coal plant in Illinois.

\subsection{PERMITTING A CLEAN COAL PLANT IN ILLINOIS}

Located in America's Midwest, the economy of Illinois is dominated by agriculture (soy beans, corn), manufacturing and transportation of goods. Importantly, there is another industry which has made its mark. Underlying nearly $70 \%$ of Illinois' territory is the second largest coal reserve in the US. According to some calculations, it represents more potential power than "all of Saudi-Arabia's and Kuwait's oil reserves combined." ${ }^{269}$ Calculations suggest that coal provides nearly $\$ 1$ billion a year to the State's economy and could

$\mathrm{CO}_{2}$ too, EPA knew that they had to strike a balance: the performance standard for electricity generation should be strict enough to ensure environmental protection without stifling commercial investment in CCS technologies. ${ }^{268}$ EPA (April 13, 2012), 'Standards of Performance for Greenhouse Gas Emissions for New Stationary Sources; Electric Utility Generating Units; Proposed Rule', Federal Register, vol. 77, no. 72, p. 22419.

${ }^{269}$ See: Illinois State Geological Survey, http://www.isgs.illinois.edu/research/coal/illinois-coal.shtml (accessed on 29 May 2013, archived under: http://www.webcitation.org/6IY2yfyfx). 
continue to do so for centuries. ${ }^{270}$ There is thus a strong economic incentive to continue using this domestic resource. Underneath Illinois lie also numerous geological reservoirs which can potentially be used for $\mathrm{CO}_{2}$ storage. The Mount Simon aquifer for example has an estimated capacity of between 27,000 and 109,000 Mton $\mathrm{CO}_{2} \cdot{ }^{271}$ For comparison: all stationary sources in Illinois together produce less than 300 Mton $\mathrm{CO}_{2} /$ year. ${ }^{272}$ With abundant coal reserves and abundant $\mathrm{CO}_{2}$ storage capacity, enthusiasm for CCS should come as no surprise.

Illinois aims to be an international frontrunner in CCS development. The Prairie State has hosted several DOE-funded demonstration projects, including the national flagship project FutureGen. And during EPA's standard-setting process (2009-2015), three socalled 'clean coal' plants were being development in Illinois. I will focus on the project which seemed most promising and received the most political and economic support: the Taylorville Energy Center. It seemed almost self-evident that CCS was feasible for this project. After all, the project was situated in Illinois and received considerable funding to demonstrate CCS at commercial-scale. Nevertheless, 'feasibility' became heavily contested in the permitting process, as I will explain in the upcoming paragraphs.

\subsubsection{The Taylorville Energy Center}

Tenaska is one of the largest private energy companies in the US. With over $9000 \mathrm{MW}$ of electric generating capacity and an annual revenue stream of around $\$ 16$ billion, the company aims to develop affordable electricity and/or synthetic gas using innovative but 'avail-

\footnotetext{
${ }^{270}$ Ibid. Environmental groups disagree with this assessment. They commissioned a study which estimated that subsidies to the coal industry actually resulted in a net loss of $\$ 20 \mathrm{~m}$ on the State's budget, if one would take externalities into account. See: McIlmoil, R., Betcher, M., \& Kass, A. (2013). The impact of coal on Illinois state budget - FY2011. Downstream Strategies and the Center on Tax and Budget Accountability.

${ }^{271}$ Assessments of storage capacity vary, depending on the assumptions made about pressure build-up, operating conditions, economic restraints, et cetera (Bachu et al., 2007; Cavanagh, Haszeldine, \& Blunt, 2010). Capacity assessments vary especially for aquifers. In general though, geologists are of the opinion that the Illinois Basin provides ample storage space for accommodating $\mathrm{CO}_{2}$ emissions from the Illinois power sector. Most electricity in Illinois is generated by coal-fired (44\%) and nuclear power plants (32\%). Source: Illinois State Geological Survey, https://www.isgs.illinois.edu/outreach/geology-resources/illinois-energy-production-and-consumption (accessed on 18 December 2014, archived under: http://www.webcitation.org/6UuPrSDZ2). Illinois ranks as the $6^{\text {th }}$ American State in terms of annual $\mathrm{CO}_{2}$ emissions.

${ }^{272}$ MGSC. (2005). An Assessment of Geological Carbon Sequestration Options in the Illinois Basin (No. DE-FC2603NT41994). Champaign, IL: Midwest Geological Sequestration Consortium.
} 
able' technologies. ${ }^{273}$ Already in 2005, Tenaska submitted plans to construct a new 630MW power plant near Taylorville, Illinois. ${ }^{274}$ The so-called Taylorville Energy Center (TEC) would be an Integrated Gasification Combined Cycle power plant. The main advantage of this type of power plant is that it can turn coal into several product streams, like electric power, synthetic gas, sulphur and ammonia, which can all be sold as commodities (see Figure 14).

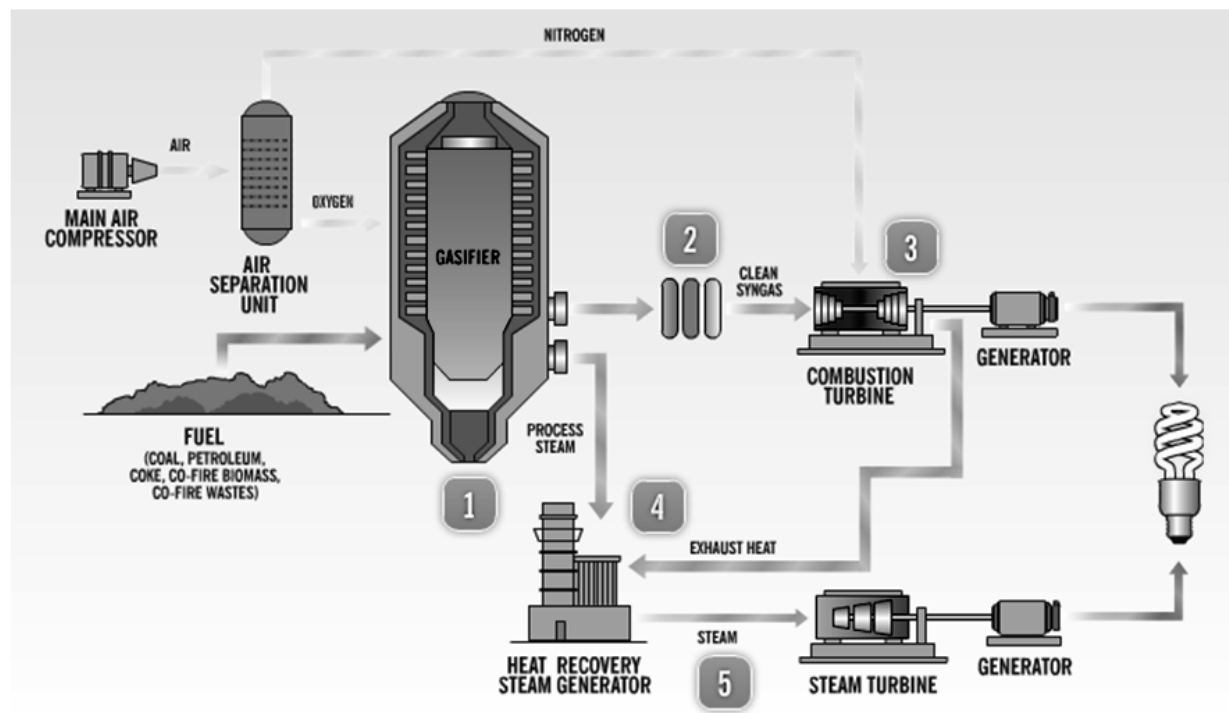

Figure 14: Schematic representation of integrated gasification combined cycle technology. Note that the flow of $\mathrm{CO}_{2}$ is not represented.

Source: www.duke-energy.com/about-us/how-igcc-works.asp, archived at: www.webcitation.org/6VQXaqurP).

Tenaska saw coal gasification as an economic opportunity in a time when the price of natural gas was still high, the oil market volatile and coal abundantly available. As coal gasification plants produce a relative pure stream of $\mathrm{CO}_{2}$, they are considered capture-ready 'by nature. ${ }^{275}$ However, actually capturing the $\mathrm{CO}_{2}$ emissions does affect a plant's reliability and thus negatively impacts its economic viability (Hoffmann \& Szklo, 2011).

\footnotetext{
${ }^{273}$ Tenaska (2009). Testimony of Dr. Gregory P. Kunkel, PhD, Vice President of Environmental Affairs, Tenaska, Inc. US House of Representatives, Committee on Energy and Commerce, Subcommittee on Energy and the Environment, p.3.

${ }^{274}$ Christian County Generation LLC submitted plans to construct the new power plant, but Tenaska was the designated operator. In the remainder of this chapter, I will simply refer to 'Tenaska' as the main project advocate. ${ }^{275}$ For more on the potential advantages of coal gasification for CCS development, see Hawkins et al. (2006).
} 
Due to changes in the American energy market (especially the boom in shale gas around 2008), it became clear that the $\$ 3.5$ billion coal gasification plant would often produce power at above-market prices. ${ }^{276}$ So, it was crucial for Tenaska to get financial and political support. This was done by promising to demonstrate CCS technologies. In August 2008, the Illinois General Assembly had introduced a so-called Clean Coal Portfolio Standard. This piece of legislation forced utilities in Illinois to buy a fixed portion of their electricity from clean coal plants. ${ }^{277}$ By promising to sequester part of its $\mathrm{CO}_{2}$, Tenaska could negotiate 30-year contracts with its future customers and could thereby significantly reduce the financial risks involved in the project. In January 2009, Tenaska also applied for a DOE loan guarantee of over $\$ 2.5$ billion. This loan guarantee was made available under the Energy Policy Act of 2005 (EPAct05) and aimed to support innovation in clean coal technologies. Tenaska calculated that this loan guarantee could save Illinois customers between $\$ 40$ and $\$ 60$ million per year. ${ }^{278}$ In July 2010, DOE awarded Tenaska another $\$ 417$ million in tax credits after the company had provided evidence that it could capture at least $65 \%$ of its $\mathrm{CO}_{2}$ emissions.

Tenaska presented TEC as "the cleanest coal-fueled power plant ever in Illinois and one of the cleanest in the world, creating 2,500 construction jobs and hundreds of permanent mining and operations jobs." ${ }^{279}$ However, not everyone was convinced by this promise. Consumer groups and small businesses feared a rise in their energy bills if TEC would come online. Environmental groups were concerned about the 4.9 Mton of $\mathrm{CO}_{2}$ which would annually be produced. In turn, an unusual blue / green alliance took shape. The 'Stop Tenaska Overpriced Power' (STOP) coalition challenged the win-win-win narrative of supporters. ${ }^{280}$ The coalition's main message to Illinois legislators was simple: "coal gasification $=$ increased costs + loss of jobs + unproven environmental benefits." 281

\footnotetext{
${ }^{276}$ The advantage of having coal gasification plants in a State's energy portfolio is that they may act as a 'hedge' against fluctuations in the energy market.

277 Clean Coal Portfolio Standard Law (SB 1987). Illinois General Assembly. Available at http://www.ilga.gov/legislation/publicacts/95/095-1027.htm (accessed on 12 June 2012, archived under: http://www.webcitation.org/6VD63qLMc).

${ }^{278}$ http://www.businesswire.com/news/home/20090713005734/en/Tenaska\%E2\%80\%99s-Taylorville-EnergyCenter-Selected-U.S.-DOE archived under: http://www.webcitation.org/6WnxGlqQu.

279 Tenaska Inc. (2010). 'Statewide poll shows Illinois voters overwhelmingly favor cleaner power from Illinois coal; Creating jobs is top energy priority'. Company press release, 10 November 2010. The other demonstration project FutureGen was accompanied by a similar 'win-win' framing (see Stephens, Markusson, et al., 2011). 280 The STOP-coalition was supported by Exelon too. Several interviewees indicated that Exelon, having six nuclear (and thus: zero emission) power plants in its portfolio, saw clean coal plants as unwelcome competition. Exelon supported the STOP-Coalition by providing money, expertise, lobbyists and 'political cloud', which is typically done via campaign donations.

${ }^{281}$ Interview with Kevin Wright, President of the Illinois Competitive Energy Association and chief-lobbyist for the STOP-coalition, July 2013.
} 
TEC invited fierce lobbying battles. To give away the ending, Tenaska ultimately failed to get crucial legislative bills passed and failed to obtain an air permit. Tenaska cancelled the project in June 2013, citing market changes and regulatory uncertainty as main reasons. The next sections will explore how evidence on the feasibility of CCS was negotiated in the permitting process. I will focus specifically on the conflicting interpretations of Illinois-EPA and EPA. ${ }^{282}$ (Note again that this debate in Illinois ran parallel to EPA's efforts to introduce a stringent standard for new coal plants at the federal level.)

\subsubsection{Illinois-EPA and the permitting process}

In April 2005, Tenaska first applied for a permit. It was obliged to use 'best available control technologies' (BACT) for regulated pollutants like nitrogen oxides, sulphur dioxide, particulate matter, carbon monoxide and sulphuric acid. Carbon dioxide was not yet on the list and Tenaska's initial project summary therefore mentioned nothing about capturing or sequestering $\mathrm{CO}_{2} \cdot{ }^{283}$ In January 2007, Illinois-EPA organized a public hearing on Tenaska's permit application, with a lot of interested parties joining. Powerful labour unions and other supporters emphasized the economic benefits of TEC. Some argued that coal gasification by itself qualified as a 'clean coal' technology (also without sequestering $\mathrm{CO}_{2}$ ). Others argued that TEC, being capture-ready by design, would contribute to CCS development in the future. ${ }^{284}$ But not everyone agreed. A representative of the Sierra Club stated that the mere "promise of a capability to capture" was too meagre. ${ }^{285}$ Environmental groups urged Illinois-EPA to mandate $\mathrm{CO}_{2}$ capture. However, the Agency responded that it lacked legal authority to do so and argued that CCS development should be encouraged by the General Assembly, not by the regulator. Furthermore, Illinois-EPA warned that "attempts to force controls or compel individual action on global warming through conventional environmental permitting programs are capricious" and could actually stifle CCS development. ${ }^{286}$ By

\footnotetext{
${ }^{282}$ Illinois is a delegated State. This means that the Illinois-EPA enacts EPA's authority under the Clean Air Act.

${ }^{283}$ Illinois EPA. (2006). Project Summary for a Construction Permit Application from Tenaska for the Taylorville Energy Center (No. 05040027). Illinois Environmental Protection Agency, Bureau of Air, Permit Section.

${ }^{284}$ A spokesperson of the environmental CATF argued for example: "We have to transition coal to a point where we capture $\mathrm{CO}_{2}$. (...) To be clear, this plant is not proposing to capture $\mathrm{CO}_{2}$, but it is a vital step in the direction of managing $\mathrm{CO}_{2}$ emissions into the atmosphere". Source: Illinois EPA. (January 11, 2007). Transcript of Public Hearing on proposed issuance of construction permit/PSD approval to Tenaska in Taylorville, Illinois Environmental Protection Agency, Bureau of Air, Permit Section, p. 26.

${ }^{285}$ Ibid, pp.43-4.

${ }^{286}$ Illinois EPA. (June 5, 2007). Responsiveness Summary for Public Questions and Comments on Tenaska's Taylorville Energy Center Power Plant Project near Taylorville, Illinois Environmental Protection Agency, Bureau of Air, Permit Section, p 6.
} 
June 2007, Illinois-EPA granted Tenaska a construction permit: no requirements on $\mathrm{CO}_{2}$ capture were included.

This reasoning shifted after EPA's Endangerment Finding of December 2009. New coal plants were now obliged to limit their $\mathrm{CO}_{2}$ emissions using 'best available control technologies.' To establish what counts as BACT, Illinois-EPA had to go through a topdown selection process:

\begin{tabular}{ll}
\hline Step 1 & Identify all available emission reduction options \\
Step 2 & Eliminate options that are technically infeasible \\
Step 3 & Rank the options by control effectiveness \\
Step 4 & Do a cost-benefit analysis \\
Step 5 & Select the highest ranking option as BACT
\end{tabular}

In November 2010, EPA published a guidance document on how to conduct a BACT analysis with respect to GHGs. ${ }^{287}$ It stated that CCS should be considered an available pollution control technology under Step 1. 'Available' meant that a technology had a potential for practical application, even though it might still be in the initial stages of development. ${ }^{288}$

When Tenaska applied for an air permit in 2012, Illinois-EPA conducted a BACT analysis. The responsible permit engineer explained that $\mathrm{CO}_{2}$ provided an "interesting challenge." CCS is not a simple add-on control technology, like a $\mathrm{SO}_{2}$ scrubber: "If one manages to economically capture $\mathrm{CO}_{2}$ from a commercial-scale power plant, the key question is still: what to do with the $\mathrm{CO}_{2}$ stream so that it will not be emitted to the atmosphere?" ${ }^{289}$ Due to the uncertainties involved, CCS was excluded in step 2 of the BACT analysis and again not mandated for Tenaska. As Illinois-EPA put it:

"The permit does not require sequestration, because this innovative technology is not yet adequately demonstrated so as to be able to definitively determine that it would be technically feasible when the plant begins operation and during its entire operating life (i.e., as BACT). However, one of the benefits of the plant should be to demonstrate the technical feasibility and reliability of $\mathrm{CO}_{2}$ sequestration." 290

\footnotetext{
${ }^{287}$ US EPA. (2010). PSD and Title V Permitting Guidance for Greenhouse Gases. Research Triangle Park, NC: US Environmental Protection Agency - Office of Air Quality Planning and Standards.

${ }^{288}$ EPA added that it did not expect CCS to be necessarily selected as BACT in Step 5 of every project.

${ }^{289}$ Interview with Permit Engineer at Illinois Environmental Protection Agency, June 2013.

${ }^{290}$ Illinois EPA. (April, 2012). Responsiveness Summary for Public Questions and Comments on the Construction Permit Application from Tenaska for the Taylorville Energy Center in Taylorville, Illinois (No. 021060ACB). Bureau of Air Permit Section.
} 
Put differently: CCS was classified as promising and theoretically feasible but did not qualify as technically feasible in the permitting context. Illinois-EPA and Tenaska argued that "considerable uncertainty" existed with respect to a number of issues, like the long-term ability of the Mount Simon aquifer to sequester $\mathrm{CO}_{2}{ }^{291}$ In turn, mandating CCS in a permit was deemed to "improperly subject Tenaska to considerable risk of unavoidable noncompliance." 292

\subsubsection{Different standards of evidence}

The emphasis on uncertainty may come as a surprise, since Tenaska had gone out of its way to reiterate the promise of CCS when applying for financial support. Sierra Club and NRDC were quick to point out that Tenaska's claim of building a 'clean' coal plant relied on its ability to store $\mathrm{CO}_{2}$. But Tenaska itself shed doubt on this ability in its permit applications! The apparent incoherence was presented as a token of bad faith, fuelling public distrust. I cannot say whether or not Tenaska had acted in bad faith. One could also interpret the company's alleged 'double-speak' differently. It is striking to see that the political and the permitting context came with different standards of evidence on CCS. The Clean Coal Portfolio Standard and DOE Loan Guarantee asked for theoretical evidence that CCS was promising. This was enough to legitimize that Tenaska received political and financial support. But in the permitting context, Illinois-EPA asked for practical proof of the technical feasibility of CCS. The difference is clear at several instances.

First, Tenaska had used a Feasibility Study by Schlumberger ${ }^{293}$ to convince Illinois legislators and DOE officials that CCS was promising and entailed only limited financial

\footnotetext{
291 Ibid, p. 114.

${ }^{292}$ Ibid. After reading this Chapter, the permit engineer at Illinois-EPA pointed to the Kemper CCS demonstration project in Mississippi. Here, CCS was qualified as BACT and so the project was meant to serve as the 'BACT template' for other projects, like Tenaska. However, the project was later cancelled due to, amongst others, shortage of funding. According to the permit engineer, this meant that also the Kemper project could not offer "solid proof" of CCS feasibility and viability.

293 Source: Schlumberger. (2010). Summary Results for: Carbon Storage Feasibility Study Taylorville Energy Center (TEC). Schlumberger Carbon Services. Schlumberger has been involved in CCS development from the mid-1990s and has recognized expertise in reservoir characterization, seismic services and geological modeling. The company website states: "With more than 80 years of experience mapping, measuring, and modeling underground rock formations, Schlumberger Carbon Services has been a pioneer in the adaptation of proven technology to address the challenges of storing $\mathrm{CO}_{2}$ underground safely, reliably, and efficiently." (http://www.slb.com/carbonservices.aspx, accessed on 29 December 2014, archived under: http://www.webcitation.org/6VD8G0iCl). For an in-depth analysis of how Schlumberger obtained its epistemic authority in the oil industry, see Geoffrey Bowker's (1994) Science on the Run: Information Management and Industrial Geophysics at Schlumberger, 1920-1940. Inside Technology Series, Massachusetts: MIT Press.
} 
risks. But this study had a different meaning in the permitting context. Here, Illinois-EPA argued:

"Although the Schlumberger study indicated favorable geologic conditions for $\mathrm{CO}_{2}$ sequestration using the Mount Simon formation, this preliminary finding does not constitute a guarantee. (...) Although the formation looks promising..., its ability to adequately hold the volume of $\mathrm{CO}_{2}$ produced by Tenaska is theoretical until demonstrated in practice." 294

According to Illinois-EPA, technical feasibility should be "demonstrated in practice." In turn, CCS was considered insufficiently demonstrated for Tenaska's project:

“Tenaska's chosen site indeed holds substantial promise for geologic carbon sequestration. As such [!], it confirms uncertainty about the achievability of sequestration technology for the project. BACT cannot be established based upon substantial promise for success." 295

The fact that CCS was merely theoretically promising meant that there remained uncertainties too. Therefore, it could not be mandated in a permit.

Second, FutureGen allowed for a Janus-faced interpretation too. Tenaska had referred to this prestigious demonstration project as evidence of (i) the suitability of Illinois geology for storing $\mathrm{CO}_{2}$ and (ii) the importance of maintaining political support for learning-bydoing. ${ }^{296}$ But in the permitting context, FutureGen was presented as "direct evidence" to show that CCS was "not currently demonstrated" and could "not yet be considered commercially available." 297 According to Illinois-EPA, this again meant that CCS could not be mandated in Tenaska's permit.

Third, Illinois hosted yet another DOE-funded demonstration project. From 2011 onwards, $\mathrm{CO}_{2}$ from an ethanol factory in Decatur was being injected into the Mount Simon aquifer. The so-called Illinois Basin - Decatur Project (IBDP) aimed "to demonstrate the commercial viability of CCS" and "to determine if $\mathrm{CO}_{2}$ can be safely stored in the deep rock formations of the Illinois Basin.”298 In October 2012, the project gained international recognition for making significant contributions to CCS development. In the context of Tenaska's permit, environmental groups argued that the "practical experience gained" and

\footnotetext{
${ }^{294}$ Illinois EPA. (April, 2012). Responsiveness Summary for Public Questions and Comments on the Construction Permit Application from Tenaska for the Taylorville Energy Center in Taylorville, Illinois (No. 021060ACB). Bureau of Air Permit Section, p. 120.

295 Ibid, p. 135.

${ }^{296}$ FutureGen had been significantly delayed after DOE withdrew its support in 2009, due to expected cost overruns. The project was later restructured and ultimately cancelled. ${ }^{297}$ Ibid, p. 129.

${ }^{298}$ See: http://www.sequestration.org/resources/topStories.html. Accessed on June 21, 2013, archived under: http://www.webcitation.org/6KjNePLe1.
} 
"wealth of data gathered" in this project constituted evidence that Illinois geology was suitable for $\mathrm{CO}_{2}$ storage (described as "the biggest source of technical uncertainty in any sequestration project"). ${ }^{299}$ But Illinois-EPA disagreed. It argued that commentators "exaggerated the usefulness of the geological data already obtained," since (i) the IBDP had only been underway for a limit period of time and (ii) "subsurface geology can vary greatly over the 30 mile distance from Decatur to Taylorville." ${ }^{300}$ In turn, Illinois-EPA ruled that this particular demonstration project (although successful) provided insufficient evidence that Tenaska could also inject its $\mathrm{CO}_{2}$ in the Mount Simon aquifer.

\subsubsection{Demonstrator's regress and EPA's intervention}

Sociologist of scientific knowledge Harry Collins (1985) has used the term 'experimenter's regress' to describe the circularity which sets in motion when there is no socially accepted criterion (yet) for determining whether a scientific experiment has been properly conducted. In such situations, debates about the quality of an experiment cannot be separated from debate about its output. I would argue that a similar 'demonstrator's regress' is at play at the forefront of technology development. When there is no socially accepted criterion (yet) for determining when the working of a technology (in terms of costs, performance, or...) has been adequately demonstrated, debate about the lessons learned from a demonstration project cannot be separated from debate about the representativeness of such projects. In case of CCS, demonstration projects are meant to show the working of CCS technologies in a particular context. Such projects receive public funding because the lessons learnt will be shared within the power sector and amongst members of the CCS community. The suggestion is that lessons learnt and experience gained applies to other contexts too. But the 'representativeness' of a demonstration project is not determined by technical characteristics alone. Capturing $\mathrm{CO}_{2}$ from an ethanol refinery may be different from capturing $\mathrm{CO}_{2}$ from a commercial-scale power plant. There are various types of power plants and various capture techniques available. There are various possible storage locations and various regulatory contexts which may affect a CCS project. So, what does it take to determine that full-scale CCS from a commercial coal plant is 'adequately demonstrated'? In principle, parties may always ask for more demonstration projects conducted under different circumstances or for the demonstration of a slightly different constellation of technologies. I propose to call this

\footnotetext{
${ }^{299}$ Illinois EPA. (2012). Responsiveness Summary for Public Questions and Comments on the Construction Permit Application from Tenaska for the Taylorville Energy Center in Taylorville, Illinois (No. 021060ACB). Bureau of Air Permit Section, p.117.

${ }^{300}$ Ibid, p. 118-9.
} 
circularity 'demonstrator's regress' and argue that it is circumvented by social convention (i.e. by imposing regulations which determine that a technology is 'in fact' adequately demonstrated) rather than technical learning alone. One could interpret the actions of EPA in this way too, as I will explain next.

NRDC and Sierra Club were infuriated by the reasoning of Illinois-EPA. Together, they filed a case for the Environmental Appeals Board (EPA's impartial adjudicator, made up of three judges that work firewalled off from the rest of the Agency's branches). Environmental groups argued that the standard of evidence which Illinois-EPA had used was flawed ad absurdum:

"If, as Illinois-EPA suggests, 30+ years of absolute certainty is what is required at the permitting stage in order for CCS to be identified as feasible in BACT Step 2, then CCS will essentially never be feasible." 301

As Tenaska's case was pending for the Environmental Appeals Board, something unusual happened. In June 2012, Illinois-EPA received a letter from EPA's Regional Administrator, urging the State Agency to reconsider its BACT analysis. This was meant to "avoid a lengthy permit appeal that could delay construction of this facility and undermine state and federal efforts to promote clean coal technology." ${ }^{302}$ Importantly, the letter was send in the same period that EPA had proposed its $\mathrm{CO}_{2}$ standard at the federal level. This NSPS sets the floor for BACT to go beyond. So, it would have been harmful in the context of litigation if CCS was classified as 'technically infeasible' for Tenaska's new coal plant (being capture-ready by nature, build in a region with excellent geology for $\mathrm{CO}_{2}$ storage and receiving federal funding to demonstrate CCS at commercial-scale!).

After receiving the letter, Illinois-EPA decided to revoke Tenaska's permit. The permit engineer working on the case typified this as a 'political' decision, because EPA had failed to submit any new evidence that could justify a revised classification of CCS:

“They claim that it's feasible to do it under Step 2. But I myself haven't really seen any documentation for that scientifically... The Obama Administration is pushing the envelope as far as they can to require companies to use CCS, even if it's not feasible or not been demonstrated a $100 \%{ }^{" 303}$

\footnotetext{
${ }^{301}$ EPA. (2012). Petition for review and request for oral argument (PSD 12-01). Washington DC: Environmental Appeals Board, p.16.

302 EPA (June 12, 2012). 'Letter by EPA's Regional Administration (Region 5) to Interim Director of IllinoisEPA'. Available at: www.yosemite.epa.gov.

${ }^{303}$ Interview with Permit Engineer at Illinois Environmental Protection Agency, June 2013. He emphasized that this was his personal opinion. Asked when Illinois-EPA would consider technical feasibility adequately demonstrated, the permit engineer pointed to the FutureGen project (delayed and ultimately cancelled) would have to be running for a few years: "I think at FutureGen they have to find out whether the technology works to sequester it.
} 
Tenaska agreed that commercial-scale CCS involved too many technical uncertainties to be mandated in a permit. As the company's Vice-President of Environmental Affairs put it:

"Did we think it was technically feasible to do sequestration on our location, based on the geology that we had? Yes. Could I prove it to the satisfaction of everyone? Well, no, not really because we hadn't done it. Nobody in the world has ever done injection at the size that we were proposing. So is it demonstrated? Uh, no... There's a lot we don't know. Would a lender, contemplating loaning billions of dollars, be satisfied with my ability to dispose of $\mathrm{CO}_{2}$ in this hole that I haven't drilled yet into geology that's not perfectly known based on some modeling that Schlumberger did? Probably not!"304

After EPA's intervention, Tenaska's permit was revoked and the company quickly lost political traction. In a desperate attempt to "meet all of the objections raised," the company proposed to feed its power plant with natural gas instead of Illinois coal. ${ }^{305}$ To little avail. Tenaska abandoned the project in June 2013, citing the changed economic outlook and uncertainty over state and federal energy regulations as important reasons. ${ }^{306}$

What can be taken from all this? This chapter explores how EPA tried to legitimize a stringent $\mathrm{CO}_{2}$ standard for new coal plants. Operating in the adversarial American context, EPA had to fight the accusation that it was waging a political 'war on coal.' No American power plant was applying CCS at commercial-scale yet. Various demonstration projects were underway, some of which were delayed or even cancelled. So to set a stringent $\mathrm{CO}_{2}$ standard, EPA had to convince others that commercial-scale CCS was feasible and would soon become adequately demonstrated. When Illinois-EPA classified CCS as not technically feasible for Tenaska's clean coal plant, EPA intervened. Instead of presenting new evidence, it pressured Illinois-EPA to come to a different conclusion in light of the evidence already provided. Put differently, it pressured Illinois-EPA to adopt a different 'standard of evidence' and to for example accept theoretical studies and experiences gained in other demonstration projects as evidence that $\mathrm{CO}_{2}$ storage would be technically feasible for Tenaska. Via this intervention (which some at Illinois-EPA qualified as a 'political' inter-

(...) FutureGen is a federal, DOE-funded project to see if oxy-combustion boilers can be an operable technology on a large scale and to find out the demonstration-viability of CCS itself. So in order to make sure that it is doable, you need federal funding first to make demonstrations.”

${ }^{304}$ Interview with Gregory Kunkel, Vice President of Environmental Affairs at Tenaska, July 2013.

${ }^{305}$ Bart Ford, Vice President of Tenaska, quoted in: Wernau, J. (2012, May 8). Tenaska wants to strike a deal that eliminates coal. Chicago Tribune.

${ }^{306}$ Landis, T. (2013, June 21). Developer pulls plug on Taylorville Energy Center. State Journal Register. Retrieved from http://www.sj-r.com/archive/x1292456584/Developer-pulls-plug-on-Taylorville-Energy-Center (archived under: http://www.webcitation.org/6VEJPDyam). Various interviewees argued that it was ultimately the shale gas revolution and rise of fracking which put a stop to coal gasification projects in Illinois. With natural gas flooding the market, transforming coal into synthetic gas simply stopped making economic sense. 
vention), EPA tried to circumvent demonstrator's regress. Let us now return to the Federal level, to see how EPA's struggle to introduce a stringent $\mathrm{CO}_{2}$ standard continued.

\subsection{SCIENTIFIC SCRUTINY, POLITICAL OPPOSITION AND LEGAL CHALLENGES}

EPA tried to legitimize a stringent standard by (i) presenting evidence that commercialscale CCS would become adequately demonstrated in the future and by (ii) including a 30year averaging option, suggesting that remaining technical and economic uncertainties would be reduced in the decades to come. Additionally, EPA tried to prescribe (sometimes through direct intervention) which uncertainties were 'normal' when building a clean coal plant. The standard proposed in April 2012 was highly controversial though. Opponents described it as a 'train wreck' that would be detrimental to the American economy. House Republicans accused EPA of waging a war on coal. A staggering 2,682,625 comments were submitted in response. ${ }^{307}$ Some applauded EPA's efforts to reduce domestic $\mathrm{CO}_{2}$ emissions. Others outright questioned the need for climate action and denied global warming. Again others (including representatives of the power sector) subscribed to the need for climate action, but argued that a $\mathrm{CO}_{2}$ performance standard was the wrong tool for the job. They emphasized that any CCS requirement would only add uncertainty to the business case for coal. The influential American Coalition for Clean Coal Electricity (an advocacy group representing major coal companies and electricity producers) prophesized for example that no new coal plant would be build in the US in case they were required to use CCS. As a side-effect, CCS development would come to a virtual stand-still. ${ }^{308}$

This was not what forced EPA to revise its proposed standard though. Legal commentators had pointed out that EPA could not refer to the emission profile of gas plants to legitimize a stringent standard for coal plants too. The Clean Air Act called for separate standards. This requirement had important repercussions, as EPA was now legally obliged to provide techno-scientific evidence on the status and future of CCS. This evidence was carefully scrutinized by internal and external parties.

\footnotetext{
${ }^{307}$ All comments are available at: http://www.regulations.gov/\#!documentDetail;D=EPA-HQ-OAR-2011-06600001.

${ }^{308}$ ACCCA. (2013). Major EPA regulations affecting coal-fueled electricity. Washington DC: American Coalition for Clean Coal Electricity.
} 


\subsubsection{Repositioning at the Science Advisory Board}

In June 2013, EPA circulated a draft of its revised standard. New coal plants would be required to capture roughly $45 \%$ of their $\mathrm{CO}_{2}$. EPA stressed that this standard was marketbased and not technology-forcing: commercial parties could either build a coal gasification plant with CCS or a pulverized coal plant with CCS to produce electricity. The draft was carefully scrutinized by other parties, including EPA's own Science Advisory Board (SAB).

Already in the 1970s, EPA installed the SAB to review the scientific and technical adequacy of its actions. Jasanoff (1990) has sketched the judicial and political background of this reform. She argues that both American courts and Congress had started to give greater responsibility for scientific interpretation to regulatory agencies like EPA. They were now allowed to follow a hybrid form of reasoning, which was based both on scientific and political considerations. A 'science policy paradigm' became institutionalized, which revolved around three elements (Jasanoff, 1990, p. 50). First, agencies were permitted to make precautionary decisions on the basis of suggestive rather than conclusive knowledge alone. Second, a 'science policy' determination (e.g. on appropriate ambient air quality standards) could be valid, even if the scientific community would not universally accept it as such. Third, when science alone was unable to provide unique answers, the choice among conflicting answers should be made by politically accountable agencies, like EPA, in accordance with their lawful regulatory mission (e.g. the Clean Air Act). So, it was acknowledged that EPA's actions on uncertain and complex issues like air pollution or hazardous waste storage would, in order to be effective, often be based on a mix of scientific and political considerations. Precisely because EPA was given such discretion, new ways were sought to assure the quality of EPA's determinations and to safeguard its epistemic authority. The Science Advisory Board was meant to provide this assurance.

The SAB has proven to be a dangerous ally for EPA, as its recommendations can be a lightning rod for controversy. In turn, the role and make-up of SAB has been heavily debated since its inception. There is a statutory requirement that SAB is 'fairly balanced in terms of point of view represented.' Interpretations of this requirement hover between two poles (Jasanoff 1990). Initially, there was a technocratic pressure to focus on peer review, known from the traditional sciences. $\mathrm{SAB}$ was portrayed as a 'neutral' arbiter. From this technocratic perspective, $S A B$ members should reflect a balance of expertise. However, it soon became clear that mimicking peer review practices was far from straightforward, because EPA's actions were based on 'regulatory science' and were often politically charged. In turn, political groups (resonating environmental and industrial interests) attempted to influence the $S A B$ appointments process. So, there was a democratic pressure which suggested that SAB should reflect a balance of interests rather than expertise. From the 1980s 
onwards, the SAB has transformed from an adversarial into a cooperative body (Jasanoff 1990). However, debate on its functioning continues to the present day, as the case of EPA's performance standard makes clear.

When EPA circulated its draft in June 2013, the Agency indicated that it would not require $\mathrm{SAB}$ review because the revised standard did not rely on new science. It was 'technology-based' instead:

"This action does not rely on new science. This action will rely on the identification of existing, proven technologies to set achievable emission standards" 309

But members of the responsible SAB Working Group were not convinced. ${ }^{310}$ First, based on the information provided, they could not determine whether "there was an adequate scientific and technological basis" for the proposed rule. Second, members felt that the peer review of information supporting EPA's proposed rule might have been inadequate. ${ }^{311}$

In December 2013, a first Fact Finding session was organized where EPA staff was invited to explain the proposed rule and its underlying science. As Sheila Jasanoff (1990, p. 98) noted, an ambiguous response from the SAB can produce regulatory paralysis at just those times when the agency is under most intense pressure to act. Strategic framing of issues offers a possible way out of this dilemma (Ibid.). The explanation of EPA staff can be understood as such: instead of presenting additional scientific or technical evidence, EPA officials stressed two things. First, the proposed standard only required partial use of CCS. This provided room for technology development and acknowledged that not all economic and technical uncertainties were (or had to be) taken away yet. It implied that CCS only had to be 'partially' demonstrated at the time the standard was introduced. Second, the proposed standard only mentioned $\mathrm{CO}_{2}$ capture. This subtle, rhetorical form of boundary work meant that scientific questions regarding $\mathrm{CO}_{2}$ storage and (the uncertainties involved

\footnotetext{
${ }^{309}$ EPA (November 12, 2013). 'Preparations for Chartered Science Advisory Board (SAB) December 4-5, 2013 Discussions of EPA Planned Agency Actions and their Supporting Science in the Spring 2013 Regulatory Agenda', p.3. Available at: www.epa.gov.

310 This particular group was chaired by a Professor in Civil and Environmental Engineering. Other members had academic expertise in occupational and environmental epidemiology, environmental engineering and economic policy analysis.

${ }^{311}$ EPA drew on economic studies conducted by the National Energy Technology Laboratory (NETL). EPA staff had indicated that such studies were peer reviewed and that EPA had not conducted additional peer review. Indeed, the NETL studies stated that initial results had been subjected to a significant peer review by industry experts, academia and government research and regulatory agencies. When asked about this process, NETL explained that EPA had provided review. However, NETL could not provide a publicly-available description of this review process and NETL staff added that primary data for coal-fired power plants had not been peer reviewed. The SAB Working Group considered this to be inadequate. This concern was later taken away after EPA staff clarified the peer review mechanism to SAB.
} 
in) full-scale CCS could be addressed elsewhere. ${ }^{312}$ The explanation triggered a debate within the SAB Working Group on the distinction between techno-scientific and sociopolicy considerations in EPA's rule-making:

"Several members spoke of the need for the work group to gather some additional information to more clearly identify the science questions and delineate science from policy. A work group member agreed and noted that the key issue is feasibility. The work group must gather information to determine whether the state of availability of CCS technology is a scientific issue or a policy determination, outside the SAB's purview." 313

SAB members only felt authorized to review the scientific judgment of EPA, not its policy considerations. Later in December 2013, the SAB met with several high-ranking EPA officials to discuss the matter further. The Associate Director of EPA's Office of Air Quality Planning and Standards underlined that the revised performance standard was indeed partly based on a policy consideration:

"Legislative history for the Clean Air Act makes it clear that the 'best system of emission reduction' technology does not need to be in actual routine use but can be projected based on existing technology... When setting a standard, this BSER determination is a policy judgment based on an evaluation of the available technologies and sector trends." 314

What did this policy judgement entail? ${ }^{315}$ CCS was not in routine use yet. EPA argued that this was not a problem, because its standard was based on the expectation (and would help to ensure) that CCS would become a normal abatement tool in the future. This was in line with funding policies for R\&D.

\footnotetext{
${ }^{312}$ E.g. in the context of the 'Federal Underground Injection Control Class VI Program for $\mathrm{CO}_{2}$ Geologic Sequestration Wells' or in debates regarding long-term liability and pore-space ownership. For an overview of broader regulatory issues that were relevant at that time, see (Wilson, Johnson, \& Keith, 2003; Stenhouse, Gale, Herzog, \& Wilson, 2005; Pollak \& Wilson, 2009).

${ }^{313}$ EPA (December 4, 2013). 'Minutes of Meeting of Science Advisory Board', Washington DC. Material of the meeting is available at:

http://yosemite.epa.gov/sab/sabproduct.nsf/a84bfee16cc358ad85256ccd006b0b4b/8120e4a3a64d4ec685257c220 0555d6b! OpenDocument $\&$ Date=2013-12-04, archived under: http://www.webcitation.org/6YXeCYcuQ.

${ }^{314}$ EPA (January 24, 2014). 'Revised Recommendations on the Adequacy of the Science Supporting the Standards of Performance for Greenhouse Gas Emissions from New Stationary Sources: Electric Utility Generation Units (2060AQ-91) listed in the Spring 2013 Regulatory Agenda', italics in original. Attachment A: Summary of SAB Meeting, p.5.

${ }^{315}$ In later minutes of meetings, the decision to only focus on $\mathrm{CO}_{2}$ capture and not on $\mathrm{CO}_{2}$ storage was qualified as a 'legal' interpretation. Indeed, EPA had to conduct its coordination work in view of changed legal grounds rather than changes in the political context in this period.
} 
After hearing this explanation, SAB members pursued no further review. EPA officials thus prevented an embarrassing stumbling block, because critics could interpret $\mathrm{SAB}$ review as a sign that the Agency had too hastily tried to introduce new regulations. The emphasis on policy considerations (supported by a strategic reframing of its revised standard) helped to avoid further scientific scrutiny. ${ }^{316}$ However, it also made EPA vulnerable to the accusation of political bias.

\subsubsection{Political attempts to curtail EPA's room for action}

EPA's revised standard triggered an extensive political debate on the Agency's use of techno-scientific evidence. In June 2013, Attorney General's of eighteen (mostly coal reliant) States published a letter, arguing that EPA had "pushed the envelope" in interpreting its legal authority to promulgate aggressive standards. They argued that CCS was "perhaps a decade away from being technologically and economically feasible." 317 In turn, these States felt no legal obligation to implement a 'flawed' standard. Political debate took place within other bodies too. EPA officials were questioned at numerous hearings organized by House Republicans (see Appendix D for an overview).

The critique voiced at such hearings was rather consistent: CCS is not sufficiently demonstrated yet to justify a stringent performance standard. In October 2013, the Subcommittees on Environment \& Energy of the House Committee on Science, Space and Technology for example organized a Joint Hearing, entitled 'EPA Power Plant Regulations: is the technology ready?' In his opening statement, Chair Stewart (R-Utah) directly challenged EPA's attempt to restrict the debate to $\mathrm{CO}_{2}$ capture alone. He emphasized that a system perspective was needed to judge whether CCS was adequately demonstrated or not:

"CCS is not one piece of equipment, rather a complicated system of many separated technologies. Each piece of chain must work in a seamlessly integrated fashion on a full scale power plant. No CCS project in the world meets this criterion." 318

In turn, the Republican chair criticized EPA's reliance on model-based arguments and future studies:

\footnotetext{
316 Selective emphasis to highlight certain aspect can be seen as a 'bridging mechanism', helping to coordinate the relation between political and techno-scientific considerations (Bijker et al. 2009).

317 State of Nebraska (September 11, 2013). 'Perspective of 18 States on Greenhouse Gas Emission Performance Standards for Existing Sources under $\$ 111$ (d) of the Clean Air Act’ (Letter to EPA), p. 17.

${ }^{318}$ https://science.house.gov/hearing/subcommittee-environment-and-subcommitte-energy-joint-hearing-epapower-plant-regulations, archived under: http://www.webcitation.org/6YXfC0bjL.
} 
"This hearing is about what unicorns, Big Foot and the 'adequately demonstrated' CCS for power plants all have in common: they are mere figments of the imagination. Talk of emission levels and cost-studies for hypothetical plants are noise to distract from the fact that, in the real world, the technology isn't ready." 319

A similar critique was expressed in various other committees. Ed Whitfield (House Republic representative of Kentucky and Chair of the Subcommittee on Energy \& Power) for example drafted a discussion bill which would prevent EPA from issuing a performance standard based on the 'best system of emission reduction,' unless such standard was achieved on average over a 12-month period by each of six commercial coal-fired power plants, located in different locations in the US. The discussion bill added that "no results obtained from any demonstration projects" could be used to legitimize a performance standard. ${ }^{320}$

So, politicians not only questioned EPA's interpretation of existing CCS demonstration projects, but also tried to curtail the role that such demonstration projects could play (as evidence) in the regulatory process. Such efforts focused on more than demonstration projects alone. They also targeted the function of EPA itself. The Republican-chaired House Subcommittee on Environment for example drafted the 'EPA Science Advisory Board Reform Act of 2014' (H.R.1422), which suggested that industry scientists were underrepresented in EPA's science advisory process. In turn, the proposed bill would bar EPA from basing its actions on regulatory science which it had reviewed itself. ${ }^{321}$ The bill passed the House in November 2014, but was never passed to Senate after the Obama Administration indicated that it would be vetoed. Critics thus looked for other ways to curtail EPA's room for regulatory climate action.

\subsubsection{Legal challenges and EPA's final rule}

The Clean Air Act provided EPA with legal authority to introduce a $\mathrm{CO}_{2}$ performance standard, based on the best system for emission reductions. An important criterion was that this technological system should be (or should soon become) 'adequately demonstrated.' But critics successfully pointed out that other legislation curtailed EPA's discretion for interpreting this criterion. In 2005, George W. Bush had signed the Energy Policy Act (EPAct05). This Act made public funding available for facilities (like the Taylorville Energy

\footnotetext{
${ }^{319}$ Ibid.

${ }^{320}$ This particular bill was also never signed into law, as President Obama indicate that he would use his veto right.

${ }^{321}$ Recall the second reason why the SAB Working Group had initially asked for review of EPA's use regulatory science under footnote.
} 
Center in Illinois) which promised to demonstrate CCS. However, the Bill also included a provision: no facility which received public funding under EPAct05 could (solely) be used as evidence that an emission control technology was 'adequately demonstrated' under the Clean Air Act. This clause had been overlooked by EPA officials and forced the Agency to again adapt its reasoning.

In January 2014, EPA proposed a revised standard of 1,100 lbs $\mathrm{CO}_{2} / \mathrm{MWh}$ for new coal plants. The Agency again referred to technology roadmaps, economic studies and demonstration projects as evidence that partial $\mathrm{CO}_{2}$ capture was adequately demonstrated. EPA added a Technical Support document to show that its determination was "not solely" based on government-funded demonstration projects. EPA for example pointed to plans by American Electric Power to scale-up $\mathrm{CO}_{2}$ capture from a $20 \mathrm{MW}$ to a $240 \mathrm{MW}$ slip stream. This project was cancelled in 2013. However, this had been due to a lack of regulatory support, not due to technical difficulties. Additionally, EPA pointed to an existing CCS project which aimed to capture $90 \%$ of the emissions from a $110 \mathrm{MW}$ power plant. This project (although still under construction) had not received financial support under EPAct05. Costs were covered by selling $\mathrm{CO}_{2}$ for enhanced oil recovery.

Obviously, a weak point of this argumentation was that no American coal plant was actually applying full-scale CCS yet. In fact, several demonstration projects (like FutureGen and the Taylorville Energy Center in Illinois) had been cancelled by $2014 .{ }^{322}$ In turn, EPA emphasized that it had legal authority to set a 'forward-looking' standard, which would stimulate the development of CCS technologies. In other words: EPA no longer presented its standard as a neutral market intervention. Now, the Agency emphasized that it pursued a 'political' agenda. The goal was not, as critics suggested, to force coal out of the American energy mix. On the contrary: the goal was to provide a regulatory driver for CCS so that new coal plants could have a place in a carbon-constrained world.

EPA's new proposal again received over 2 million comments. The Agency intended to finalize its rule by mid 2015. In the mean time, lobbying efforts shifted to the US Office of Information and Regulatory Affairs, which had to review EPA's standard before it could be submitted to the US Office of Management and Budget (OMB). The industry-funded Center for Regulatory Effectiveness warned for example that EPA had failed to conduct an "independent external peer review" even though this was required by OMB's rules on data quality assurance. It was suggested that EPA should either issue a less stringent standard or initiate a peer review process after all (using public participation and consultation by indus-

\footnotetext{
${ }^{322}$ For more on the restructuring and cancellation of FutureGen, see e.g. Folger (2013b). By 2014, several other commercial-scale CCS demonstration projects in the US had been hampered by significant cost overruns (e.g. the Kemper Plant in Mississippi or the Duke Edwardsport Facility in Indiana).
} 
try experts). ${ }^{323}$ In a letter, EPA dismissed this critique. The Agency simply stated that its standard would be based on "sound science" and that OMB's requirements were met. ${ }^{324}$ Still, it long remained unclear what the final standard would look like.

The debate was further complicated by EPA's efforts to regulate existing power plants too. The so-called 'Clean Power Plan' is the central element of Obama's climate strategy. CCS only plays a minor role in this plan, but there is an indirect connection: regulations on new power plants have to be in place before EPA can regulate existing power plants. So, legal challenges to EPA's performance standard could delay the Clean Power Plan too. In May 2015, Agency staff hinted that EPA might therefore strategically opt for a less stringent performance standard. ${ }^{325}$ This could help to avoid litigation and, since no new coal plants were expected in the years to come anyways due to the availability of cheap natural gas, the environmental impact would be minimal. However, commentators warned that this strategic decision could have a downside too: it could undermine the credibility of President Obama's sought-after leadership at the upcoming UN Climate Change Conference in Paris. Failure to implement a stringent $\mathrm{CO}_{2}$ standard in the US could give other nations, i.e. those in the $\mathrm{EU}$, a reason to delay stringent climate measures. ${ }^{326}$

In August 2015, EPA's final rule was passed by the OMB. A new coal-fired power plant typically produces over $1,600 \mathrm{lbs} \mathrm{CO}_{2} / \mathrm{MWh}$. The new standard determines that this should be reduced to $1,400 \mathrm{lbs} \mathrm{CO}_{2} / \mathrm{MWh}$, which can be done by applying CCS or by cofiring a significant amount of natural gas. The final rule is more lenient than the $1,100 \mathrm{lbs}$ $\mathrm{CO}_{2} / \mathrm{MWh}$ originally proposed. ${ }^{327}$ Still, it is expected to invite new legal challenges. Some attorneys have already identified EPA's determination that (partial) CCS is 'adequately demonstrated' as an important weak spot, which can be used to oppose EPA's climate approach altogether.

\footnotetext{
${ }^{323}$ Source: Center for Regulatory Effectiveness, February 2 2014, 'CRE Letter to EPA Administrator', available at: http://www.thecre.com/forum10/?p=198, archived under http://www.webcitation.org/6bXThLtDA.

${ }^{324}$ EPA, March 10 2014, 'Letter to Mr. Jim Tozzi, Center for Regulatory Effectiveness', US Environmental Protection Agency, Office of Air Quality Planning and Standards.

${ }^{325}$ Source: http://www.eenews.net/stories/1060022783, archived under http://www.webcitation.org/6aVLtLdn4j. See also: http://insideepaclimate.com/share/177625, archived under http://www.webcitation.org/6aWuaoUfU.

${ }^{326}$ The UK is the only EU country with a performance standard for coal-fired power plants. Note that it includes an exception for power plants participating in CCS demonstration projects.

${ }^{327}$ And more lenient than the $900 \mathrm{lbs} \mathrm{CO}_{2} / \mathrm{MWh}$ standard adopted by the UK government.
} 


\subsection{CONCLUSION}

As there is continued political opposition to binding federal climate action, the Obama Administration has recently pursued a regulatory climate strategy. A crucial element is a $\mathrm{CO}_{2}$ standard for new American coal plants. This chapter explored how EPA tried to introduce such a standard. I have shown that EPA engaged in boundary work, in the sense that it collected techno-scientific evidence from a variety of groups to show that CCS met the criteria of the Clean Air Act and, simultaneously, tried to shape these criteria during the regulatory process.

This is not to argue that there was anything wrong with EPA's actions. Introducing a regulatory standard always involves some form of boundary work by which regulators carve out a techno-scientific basis for their actions (see e.g. Jasanoff 1995). The question then remains: why was it so difficult for EPA to issue a stringent $\mathrm{CO}_{2}$ standard for new coalfired power plants? I have introduced the notion of 'demonstrator's regress' to answer this question. Listening sessions made clear that environmental and industrial groups disagreed on the 'readiness' of CCS. To accommodate this difference, EPA decided to issue a forward-looking standard and presented evidence that commercial-scale CCS would become adequately demonstrated in the future. It referred to experiences gained in earlier CCS demonstration projects, to plans and funding for new demonstration projects and to scientific studies on future CCS development. However, such evidence proved ambiguous. Some critics called for more demonstration projects, conducted under different circumstances. Others argued that previous projects had not demonstrated the working of CCS but had resulted in unexpected surprises and glitches and had only demonstrated that significant technical and economic uncertainties remained in linking CCS to a full-scale power plant. Again others argued that government-funded demonstration projects should be dismissed as evidence of the working of CCS altogether. This is what I have called 'demonstrator's regress'. It refers to the circularity which sets in motion at the forefront of technology development, when there is no socially accepted criterion (yet) for determining when the working of a technology is adequately demonstrated. One could always ask for more technology demonstrations, conducted under different circumstances. Pointing to technical properties alone will hardly settle the debate. Circumventing demonstrator's regress arguably requires social intervention. We have seen an example of this in case of the Taylorville Energy Center. When Illinois-EPA qualified CCS as not technically feasible for Tenaska's clean coal plant (arguing that $\mathrm{CO}_{2}$ storage was not adequately demonstrated yet), EPA intervened. It pressured Illinois-EPA to come to a different conclusion in light of the evidence already provided. 
So, a stringent $\mathrm{CO}_{2}$ standard forced EPA to circumvent demonstrator's regress. This made it difficult to maintain that its standard was based upon techno-scientific evidence on which all consulted parties agreed. When pressured in front of the Science Advisory Board, EPA officials acknowledged that their standard was partly based on a 'political' agenda: stimulating the development of CCS technologies. Whether it is acceptable for a regulator to take on this role depends on the context. As shown in this chapter, EPA's room for manoeuvring was heavily curtailed by legal challenges and political opposition (e.g. meant to increase the number of industry experts in EPA's internal Science Advisory Board). Anticipating further legal challenges, EPA ultimately decided to opt for a less stringent standard. At the time of writing, it is still unclear whether this standard can ensure timely implementation of CCS in the US.

It should be noted that different nations put different regulations in place to govern the commercialization of CCS. In the context of the EU, there is for example continued debate about imposing $\mathrm{CO}_{2}$ regulations too. Analysts argue that the EU-ETS has failed to stimulate CCS (e.g. Chappin \& Dijkema, 2009). It is simply cheaper for companies to buy extra allowances and vent their $\mathrm{CO}_{2}$ in the atmosphere then to capture it and store it underground. In turn, additional approaches were sought to ensure timely implementation of CCS. In 2008, the Environment Committee of the European Parliament proposed to introduce a regulatory standard which would make CCS practically compulsory for new coal plants. However, the European Commission settled instead for a so-called 'captureready $^{328}$ requirement (S. Fischer, 2012). The CCS Directive of 2009 demands that new coal plants are designed in such a way that they can technically capture and store $\mathrm{CO}_{2}$ in the future (when this is considered economically feasible under the market-based EU-ETS). The effectiveness of this regulative approach is increasingly questioned though. Innovation scholars Markusson \& Haszeldine $(2009,2010)$ argue for example that the capture-ready requirement provides little guarantee against the risk of 'carbon lock-in' and could even make it worse. The new coal-fired power plants in the Rotterdam region are arguably a case in point (compare Vergragt, 2009b). They were designed with CCS in mind and operators made public promises to store $\mathrm{CO}_{2}$ emissions. However, the demonstration project which was supposed to kick-start CCS was significantly delayed due to the low price of $\mathrm{CO}_{2}$ under the EU-ETS (Chapter 2). Other demonstration projects have been cancelled for the

\footnotetext{
${ }^{328}$ Numerous definitions of 'capture-readiness' are in circulation worldwide. In 2010, this prompted an international workshop to establish a standard definition (see

http://www.globalccsinstitute.com/insights/authors/christophershort/2010/11/03/definition-ccs-ready, archived under: http://www.webcitation.org/6VSEW1Fel). Workshop participants agreed that 'capture ready' is not actually a mitigation option, but a way to facilitate $\mathrm{CO}_{2}$ mitigation once the necessary economic and regulatory drivers are in place in the future. This Chapter explores the (contested) introduction of such a driver in the American context.
} 
same reason (Scott, 2013). In this context, there is renewed debate on whether additional regulations should be put in place to govern timely commercialization of CCS (and whether these regulations should be implemented at the national or EU level). ${ }^{329}$

Again, the ways by which such debates are settled will differ from region to region (see also the extensive body of literature on Trans-Atlantic differences in environmental regulation and regulatory cultures (e.g. Vogel 1986; Löfstedt \& Vogel 2001; Wiener et al. 2011)). I do not want to suggest that the precise dynamic of the regulatory process in the selected American case will be the same in debates elsewhere. However, I do maintain that a perspective on boundary work is helpful for understanding how actors try to legitimize regulatory interventions in energy markets, since such regulations typically have to be based on the 'state of technology development' (in Dutch: stand der techniek). And it does seem fair to conclude that the introduction of a regulatory standard for new coal plants (able to ensure commercial-scale application of CCS) will force regulators to look for ways to circumvent demonstrator's regress. After all, numerous demonstration projects have been cancelled or delayed worldwide, so it is difficult to suggest that CCS has already reached the final stage of technology readiness. It is ironic to see that industrial groups (who have long emphasized the promise of CCS to legitimize continued use of fossil fuels) now emphasize the uncertainties involved in CCS when discussing regulatory obligations to reduce their $\mathrm{CO}_{2}$ emissions via CCS.

\footnotetext{
${ }^{329}$ The United Kingdom (having abundant offshore $\mathrm{CO}_{2}$ storage capacity) adopted a performance standard of $900 \mathrm{lbs} \mathrm{CO}_{2} / \mathrm{MWh}$ in December 2013, de facto forcing new coal plants to apply CCS. (Note that there is an exception clause for companies participating in public-private CCS demonstration projects). Environmental groups like Bellona have called for an EU-wide or international adoption of such a standard, which will be discussed in the upcoming UN Climate Change Conference in Paris.
} 

Conclusions and reflection 
There is a strong consensus within the scientific world that climate change is real and in need of urgent action (Oreskes, 2004). Additionally, most governments of developed economies agree that large-scale implementation of CCS is crucial. For this, they draw on reports by influential bodies like the IPCC and the IEA which stress that underground $\mathrm{CO}_{2}$ storage is a necessary, safe and feasible element of any cost-effective climate strategy. Such reports are typically portrayed as the consensus view of leading experts in the world. However, knowledge that is claimed to have universal authority is received and interpreted very differently in different political and cultural settings (Jasanoff, 2004). As Hulme puts it:

"Consensus science... might look persuasive from the centralized sites of production. The views from the peripheries of space, of power and of culture - the very places where knowledge is consumed - look very different. We need to understand this story and tell it widely" (Hulme, 2008, p. 9)

This thesis tells such a story. I have investigated why the implementation of CCS is marked by controversy and delay, even though the consensus discourse suggests that underground $\mathrm{CO}_{2}$ storage is necessary, safe and feasible.

The consensus discourse implies that there are no serious techno-scientific objections to capturing large quantities of $\mathrm{CO}_{2}$ and storing it in the deep underground. As a consequence, the consensus discourse suggests that the slow implementation of CCS is mainly due to socio-political barriers: lack of economic incentives, lack of public acceptance and lack of appropriate regulations. ${ }^{330}$ This may be partially true. But to understand how democratic societies have dealt with these perceived barriers and to understand why it is so difficult to remove them, the consensus discourse has little to offer. In fact, it only makes the contemporary situation more puzzling. If CCS is a necessary part of any cost-effective climate strategy, how can there be a lack of economic activity? If underground $\mathrm{CO}_{2}$ storage is unambiguously safe, why is it so difficult to settle debates about safety? And if commercial-scale CCS is technically feasible, why are there insufficient regulations in place to ensure its application to prevent major new polluters? To answer such questions, I argue that we should not treat the necessity, safety and feasibility of CCS as unambiguously given. Similarly, the mentioned barriers cannot simply be attributed to a knowledge deficit amongst politicians or members of the public. Instead, I show that the slowness of CCS implementation is better understood by exploring how knowledge on CCS is negotiated while actors seek to legitimize their ac-

\footnotetext{
${ }^{330}$ For example: "There are no technical or physical barriers to [geological sequestration]... The only thing that stands in the way of progress at the moment is policy" (Nicholls, 2007, p. 16). A similar message is found in reports by e.g. the US Interagency Taskforce on CCS (2010) or the Global CCS Institute (2011). See also Bachu (2008), Bäckstrand et al. (2011, p. 277), Davies et al. (2013) or Young-Lorenz \& Lumley (2013) for publications in the academic domain.
} 
tions on CCS resulting in the strengthening or lowering of barriers to implementation. This thesis offers three analytical perspectives to gain such an understanding.

The perspective on socio-technical imaginaries was used to understand how CCS became a 'necessary' part of the Dutch energy future. In the Netherlands a broad range of actors is involved in realizing energy reform. This led to the use of various reflexive and inclusive knowledge creation practices (like energy dialogues, back-casting exercises, nonbinding energy agreements and the transition management approach) for exploring what a viable energy future might look like. In this context, visions of $\mathrm{CO}_{2}$ hubs and roundabouts provided a powerful image that called for CCS, because this imaginary promised that the Netherlands could benefit from attracting international flows of $\mathrm{CO}_{2}$. These visions of CCS drew upon (and allowed for) a redefinition of the climate problem: it was no longer by reducing fossil flows but by handling $\mathrm{CO}_{2}$ streams that the Dutch networked nation could prosper in a future of climate change. This helped to legitimize the construction of new coal-fired power plants, as these facilities were expected to be abated in the future. The prospect of becoming an international $\mathrm{CO}_{2}$ hub also allowed industrial and environmental groups to agree on quite stringent climate objectives. It is this combination which made CCS a 'necessary' part of the Dutch energy future.

Studying energy imaginaries thus helps to understand what is deemed necessary in energy policy, which CCS policies are drafted, and what types of CCS projects are then pursued. However, for understanding what then happens to those projects, we need something else. The perspective on frames and overflows helps to understand how actors reach agreement on concrete CCS projects and how knowledge on, for example, safety is negotiated in this process. The dynamic of the Barendrecht case is to be understood against the background of the larger Dutch energy imaginary that CCS is necessary. This necessity suggested that there would be broad societal support for such an energy future with CCS. Hence deliberative and participatory knowledge practices were set up to form this societal support and further build on it. Environmental NGOs were enrolled as representatives of public concerns and engaged in dialogues with representatives of industry and government. The project evaluations were now framed as safety questions, since the necessity had already been established. The organizer of the Energy Dialogue Netherlands even hoped that the agreement at the national level about the necessity of CCS would deem opposition at the local level to be a mere NIMBY argument. But then overflows happened, and the safety discussion could not be contained. One overflow was the failure to contain the discussion at the local level, when the national government was drawn into the controversy with two ministers. The second overflow happened when the credibility of who counted as experts was questioned. The framing and overflow perspective shows how decision-making is not only shaped by the dominant imaginary, but also by the framework of existing regulation. One example is the 'external safety' 
regulation which led to choosing a semi-quantitative risk analysis. But regulatory frameworks are not static. Participants constantly try to reinterpret and renegotiate and reflexively update regulations as they try to govern timely implementation of a project. To understand how such regulations are put in place and how knowledge on CCS gets negotiated in the process, the 'boundary work' perspective is helpful.

The US Environmental Protection Agency tried to introduce a $\mathrm{CO}_{2}$ standard. EPA has to make clear that its standards are based on technical and scientific evidence rather than shaped by political agendas. However, what constitutes 'good evidence' and how such evidence should be interpreted is not self-evident. EPA typically engages in boundary work to carve out an appropriate scientific basis, in this case for its carbon rule. EPA provided evidence that CCS is 'technically feasible' and 'adequately demonstrated'. However, during that process EPA had to reshape the interpretation and application of these criteria. It had become clear that commercial-scale CCS still had uncertainties and that the technologies involved were not yet demonstrated at commercial-scale. EPA then argued that only partial demonstration of technical feasibility and commercial viability was required since new coal plants would only have to sequester only half of their $\mathrm{CO}_{2}$ emissions. Second, the proposed standard only mentioned $\mathrm{CO}_{2}$ capture. This subtle, rhetorical form of boundary work meant that scientific questions regarding $\mathrm{CO}_{2}$ storage and (the uncertainties involved in) full-scale CCS could be addressed elsewhere.

Using the three perspectives of imaginaries, frames and boundary work, we can understand the course of events in these CCS cases. More specifically, it helps to understand why CCS is so much slower to develop than could be expected on the basis of scientific reports on CCS. In the Netherlands, the imaginary of a networked nation resulted, for example, in extra tensions in the Dutch governance at European and national levels which slowed down the implementation of CCS. The Dutch government translated its networked CCS imaginary into active support of the integrated European energy market with its emission trading scheme (EU-ETS). In this European trading scheme, individual companies base their choice to invest in CCS on the price of $\mathrm{CO}_{2}$ rather than by reference to the Dutch energy future. Carbon-intensive energy companies therefore lobby at the EU-level for a low price of $\mathrm{CO}_{2}$. This undercuts the possibilities for early investments for a networked CCS future. In the Barendrecht case, the framing of the project evaluation as an issue of safety seemed straightforward as the MER concluded rather unequivocally with "yes, it is safe." But then overflows occurred by questioning the operationalization of safety criteria by the Cie-MER and the scientific credibility of some of the experts. Thus a framing which initially seemed to create a smooth implementation path turned into a cause for delay and even cancellation. In the case of American CCS, the boundary work that the EPA engaged in initially seemed an effective instrument in the Obama Administration's wish for a credible climate 
change policy. But then this same boundary work produced a less stringent standard than EPA had originally aimed for.

I highlighted the importance of 'imaginaries' for understanding how the necessity of CCS was established as part of a Dutch vision of a networked energy society; the importance of 'frames and overflows' in tracing how the safety of CCS in Barendrecht was first constructed and then deconstructed; and the importance of 'boundary work' to make visible how EPA managed various forms of expertise and evidence to establish a CCS standard. However, as I mentioned in the introduction, these three perspectives are not restricted to the cases in which I have discussed and used them. In the case of EPA's standardization efforts, it is significant that the US have an imaginary of energy independence which stimulated CCS efforts. Boundary work played an important role in validating the various forms of (especially scientific) expertise provided by the CATO network in the Barendrecht case. And framing the Dutch CCS debate in terms of a European energy market helped to stabilize the necessity of CCS.

I will, coming to the end of my conclusion and reflections, discuss the ambition and scope of this thesis. My ambition has been to offer understanding of the development of CCS and particularly of the slowness of its adoption, even though initially all 'scientific' indicators suggested an unproblematic adoption. This understanding comes in the form of new insights about the basic mechanisms that are at play in CCS developments. These mechanisms were made visible by studying socio-technical imaginaries, frames and overflows, and boundary work. This new understanding does not come in the form of an explanatory theory that can predict the outcome of a CCS discussion under specific conditions. (Nevertheless, see below for a weaker form of foresight and advice.) The scope of the analysis is all CCS projects and developments, anywhere in the world. My claim is that all CCS projects can be studied by the combination of three perspectives that I employ, and that the combination of those three perspectives gives maximum insight in any particular CCS project. This is not to say that future empirical research may not find that, for example, CCS in newly emerging economies cannot be understood with this combination of three perspectives - but at this moment there is no theoretical reason for assuming such differentiation.

Not aiming at causal explanations does not imply that my analysis cannot yield futureoriented conclusions. One is that socio-technical imaginaries result in some degree of path dependency. Imaginaries will often be different under different geographical, political and cultural circumstances and they may change over time. But since they are culturally embedded and institutionalized, it is not possible to simply 'switch' imaginaries. Sociotechnical imaginaries thus result in some inertia of developments, and can best be considered as the backdrop against which more short-term developments play out. A second poli- 
cy-related conclusion is that when framing a decision-making process, it is advisable to include a broad range of deliberative and participatory methods and forms of communication. There is indeed much experimentation with such methods in the international CCS community. ${ }^{331}$ This does not imply, however, that the choice of such methods is a guarantee for success.

This book underlines that implementing CCS invites questions of science and technology as much as power and democracy. It is striking that advocates of timely, large-scale implementation of CCS are becoming increasingly disenchanted with further 'democratization' of collective climate action (in so far as this means more time-consuming deliberation without reaching consensus or more stakeholder participation without finding a middle ground between economic and environmental concerns). Various respondents from the CCS community noted for example, tongue-in-cheek, that they preferred a 'Chinese' governance approach: the ability to override dissenting viewpoints (be they of climate sceptics, of fragmented publics or of established fossil energy companies) was seen as crucial to put cost-effective yet unpopular climate measures in place. ${ }^{332}$ I hardly think that this is a desirable alternative. Still, it does underline that democratic societies have to rethink established and experiment with alternative ways to realize energy reform, given the urgency of the climate problem.

\footnotetext{
331 See for example Brunsting et al. (2011) and Ashworth et al. (2012).

${ }^{332}$ Nico Stehr (2015) argues that a similar disenchantment with democracy is visible amongst climate experts.
} 
Appendices 


\section{APPENDIX A - LIST OF INTERVIEWEES}

\begin{tabular}{|c|c|c|c|}
\hline Initials & Function & Date & Location \\
\hline $\mathrm{HK}$ & $\begin{array}{l}\text { Senior Policy Advisor at DCMR / Project Manager Industry at } \\
\text { Rotterdam Climate Initiative }\end{array}$ & 31 May 2011 & Rotterdam \\
\hline SS & Consultant at CO2NET / Partner in EU's CO2Europipe project & 7 July 2011 & Rotterdam \\
\hline EB & Chair of non-governmental organization CO2NTRAMINE & 8 July 2011 & Groningen \\
\hline $\mathrm{MH}$ & $\begin{array}{l}\text { Alderman of Economy, Harbour and Environment at Rotterdam } \\
(2007-2009)\end{array}$ & 18 July 2011 & Rotterdam \\
\hline RS & Campaign Leader Climate \& Energy, Greenpeace NL & 19 July 2011 & Rotterdam \\
\hline $\mathrm{RM} \& \mathrm{AJ}$ & $\begin{array}{l}\text { Head Energy \& Process industry, Port of Rotterdam / Business } \\
\text { Developer Gas \& Power, Port of Rotterdam }\end{array}$ & 13 August 2011 & Rotterdam \\
\hline JB & Program Director CATO-2 & 31 August 2011 & Utrecht \\
\hline $\mathrm{JdV}$ & Business Development Team -offshore $\mathrm{CO}_{2}$ storage at TAQA & 7 September 2011 & The Hague \\
\hline AS & Manager CCS at Electrabel - GDF Suez & 14 October 2011 & Arnhem \\
\hline MR & Business Development Manager at E.ON Benelux & 18 October 2011 & Schiedam \\
\hline PT & Chair of Vereniging van Verontruste Burgers Voorne & 3 November 2011 & Eindhoven \\
\hline GB & Former Project Leader at ROM-Rijnmond & 7 November 2011 & Rotterdam \\
\hline EL & Director of Stichting de Noordzee & 8 November 2011 & Utrecht \\
\hline EV & Director of Zuid-Hollandse Milieu Federatie & 14 November 2011 & Rotterdam \\
\hline DB & $\begin{array}{l}\text { Petro physicist at TNO Netherlands Organization for Applied } \\
\text { Scientific Research }\end{array}$ & 15 November 2011 & Utrecht \\
\hline $\mathrm{BE}$ & Member of European Parliament for the Green Party & 25 November 2011 & (Telephone) \\
\hline TA & Chair of GroenLinks-Barendrecht & 25 November 2011 & Barendrecht \\
\hline $\mathrm{AB}$ & Chair of GroenLinks-Rotterdam & 1 December 2011 & Rotterdam \\
\hline $\mathrm{FN}$ & Senior Project Manager $\mathrm{CO}_{2}$ storage at TNO & 1 December 2011 & Utrecht \\
\hline $\mathrm{JK}$ & Researcher Innovation Management at Ecofys & 13 December 2011 & (Telephone) \\
\hline CK & $\begin{array}{l}\text { Project Manager eco-toxicological hazard assessment and risk } \\
\text { analysis at Imares }\end{array}$ & 16 December 2011 & Den Helder \\
\hline $\mathrm{JvS}$ & Knowledge broker at De Gemeent & 16 December 2011 & Utrecht \\
\hline MV & Secretary of Municipality Barendrecht & 15 November 2012 & Dordrecht \\
\hline TW & Geoscientists and Project Leader at TNO & 9 January 2013 & Utrecht \\
\hline CRD & Chair of CDA-Barendrecht & 17 January 2013 & Barendrecht \\
\hline $\mathrm{KP}$ & Member of CO2isNEE & 17 January 2013 & Barendrecht \\
\hline $\mathrm{AD} \& \mathrm{BvE}$ & $\begin{array}{l}\text { Director Expertise Centrum DCMR \& Project Manager CCS at } \\
\text { RCI/DCMR }\end{array}$ & 4 February 2013 & Schiedam \\
\hline AvD & $\begin{array}{l}\text { Former employee of Staatstoezicht op de Mijnen } \\
\text { (and participant in Knowledge Table Sessions) }\end{array}$ & 11 March 2013 & Brussels \\
\hline $\mathrm{JJ}$ & Chairman of VVD-Barendrecht & 13 March 2013 & (Telephone) \\
\hline
\end{tabular}




\begin{tabular}{|c|c|c|c|}
\hline Initials & Function & Date & Location \\
\hline$\overline{\mathrm{KdJ}}$ & Professor Anorganic Chemistry at Utrecht University & 14 March 2013 & Utrecht \\
\hline $\mathrm{HB}$ & Former Project Director CCS at EZ/VROM & 15 March 2013 & Amsterdam \\
\hline HvG \& JP & $\begin{array}{l}\text { Inhabitants of Barendrecht \& participants in CATO's Fact } \\
\text { Finding Workshop }\end{array}$ & 15 March 2013 & Rotterdam \\
\hline $\mathrm{HB}$ & Head Risk Management at Safety Region Rotterdam & 27 March 2013 & Rotterdam \\
\hline $\mathrm{EvH}$ & $\begin{array}{l}\text { Former Deputy Environment, Climate and Energy at Province } \\
\text { of South-Holland }\end{array}$ & 25 April 2013 & (Telephone) \\
\hline $\mathrm{JC}$ & Former Minister of Environmental Affairs (VROM) & 29 April 2013 & (Telephone) \\
\hline KM & Climate \& Energy Director - Greenpeace USA & 16 May 2013 & Chicago \\
\hline (Anonymous) & Project Manager - Leucadia & 22 May 2013 & Chicago \\
\hline $\mathrm{BP}$ & Grass Roots Organizer- Prairie Rivers Network & 28 May 2013 & Champaign \\
\hline MK & Director -Office of Major Demonstrations at DOE/NETL & 4 June 2013 & (Telephone) \\
\hline (Anonymous) & Permit Engineer - Illinois Environmental Protection Agency & 10 June 2013 & Springfield \\
\hline $\mathrm{PH}$ & President - Illinois Coal Association & 10 June 2013 & Springfield \\
\hline $\begin{array}{l}\text { MG \& GP } \\
\& \mathrm{NM}\end{array}$ & $\begin{array}{l}\text { Senior Attorney - NRDC Climate \& Air Program / Chief } \\
\text { Scientist - NRDC's Climate Center / Policy Advocate NRDC's } \\
\text { Midwest Program }\end{array}$ & 13 June 2013 & Chicago \\
\hline $\mathrm{JT}$ & Director Coal Transition - Clean Air Task Force & 26 June 2013 & (Telephone) \\
\hline GK & Vice-President of Environmental Affairs - Tenaska Inc. & 2 July 2013 & (Telephone) \\
\hline MM \& PW & $\begin{array}{l}\text { Program Director - Illinois Office of Coal Development / } \\
\text { Researcher - Illinois Department of Commerce \& Economic } \\
\text { Opportunity }\end{array}$ & 5 July 2013 & Springfield \\
\hline $\mathrm{TW}$ & Director Coal Research Center - Southern Illinois University & 8 July 2013 & Carbondale \\
\hline $\mathrm{CB}$ & Director - Faith in Place & 11 July 2013 & Chicago \\
\hline KW & Director - Illinois Competitive Energy Association & 11 July 2013 & Chicago \\
\hline PS \& TS & Directors - Southeast Environmental Task Force & 12 July 2013 & Chicago \\
\hline JW & Executive Director - Illinois Environmental Council & 15 July 2013 & Chicago \\
\hline
\end{tabular}




\section{APPENDIX B - CHRONOLOGY OF THE BARENDRECHT CONTROVERSY}

\begin{tabular}{|c|c|c|c|}
\hline Period & Procedures & Important gatherings & Publications \\
\hline April 2007 & Start of national tender procedure & & \\
\hline $\begin{array}{l}\text { Jul - Sep } \\
2007\end{array}$ & & & $\begin{array}{l}\text { AMESCO - Generic } \\
\text { environmental impact } \\
\text { assessment for CCS }\end{array}$ \\
\hline $\begin{array}{l}\text { Jan }- \text { Mar } \\
2008\end{array}$ & $\begin{array}{l}\text { Start MER procedure Barendrecht } \\
\text { End public consultation period } \\
\text { Advice of cie-MER }\end{array}$ & $\begin{array}{l}\text { Information Session I- } \\
\text { Barendrecht }\end{array}$ & Startnotitie MER Barendrecht \\
\hline $\begin{array}{l}\text { Apr }- \text { Jun } \\
2008\end{array}$ & $\begin{array}{l}\text { Shell submits 'Plan van Aanpak' to } \\
\text { Dutch government }\end{array}$ & $\begin{array}{l}\text { Information Session II - } \\
\text { Barendrecht }\end{array}$ & $\begin{array}{l}\text { TEBODIN - Safety analysis } \\
\text { Barendrecht }\end{array}$ \\
\hline $\begin{array}{l}\text { Oct }- \text { Dec } \\
2008\end{array}$ & $\begin{array}{l}\text { Dutch governments grants Shell } € 30 \\
\text { million for Barendrecht project } \\
\text { Municipal government (GB) } \\
\text { approves alternative 'Toetskader' } \\
\text { Period for submitting viewpoints and } \\
\text { comments on MER Barendrecht }\end{array}$ & & Final MER Barendrecht \\
\hline $\begin{array}{l}\text { Jan }- \text { Mar } \\
2009\end{array}$ & $\begin{array}{l}\text { End of period for submitting } \\
\text { viewpoints on MER Barendrecht }\end{array}$ & $\begin{array}{l}\text { Knowledge Table Sessions: } \\
\text { - External safety } \\
\text { - Underground } \\
\text { - Monitoring } \\
\text { - Site selection } \\
\text { Theater session I- } \\
\text { Barendrecht } \\
\text { Public consultation } \\
\text { 'Commissie Ruimte' - GB } \\
\text { Opening 'Informatiepunt' } \\
\text { Barendrecht }\end{array}$ & $\begin{array}{l}\text { Opinion piece Krijn de Jong - } \\
\text { newspaper NRC } \\
\text { Veiligheidsregio Rotterdam } \\
\text { Rijnmond comments on safety } \\
\text { study by TEBODIN }\end{array}$ \\
\hline
\end{tabular}




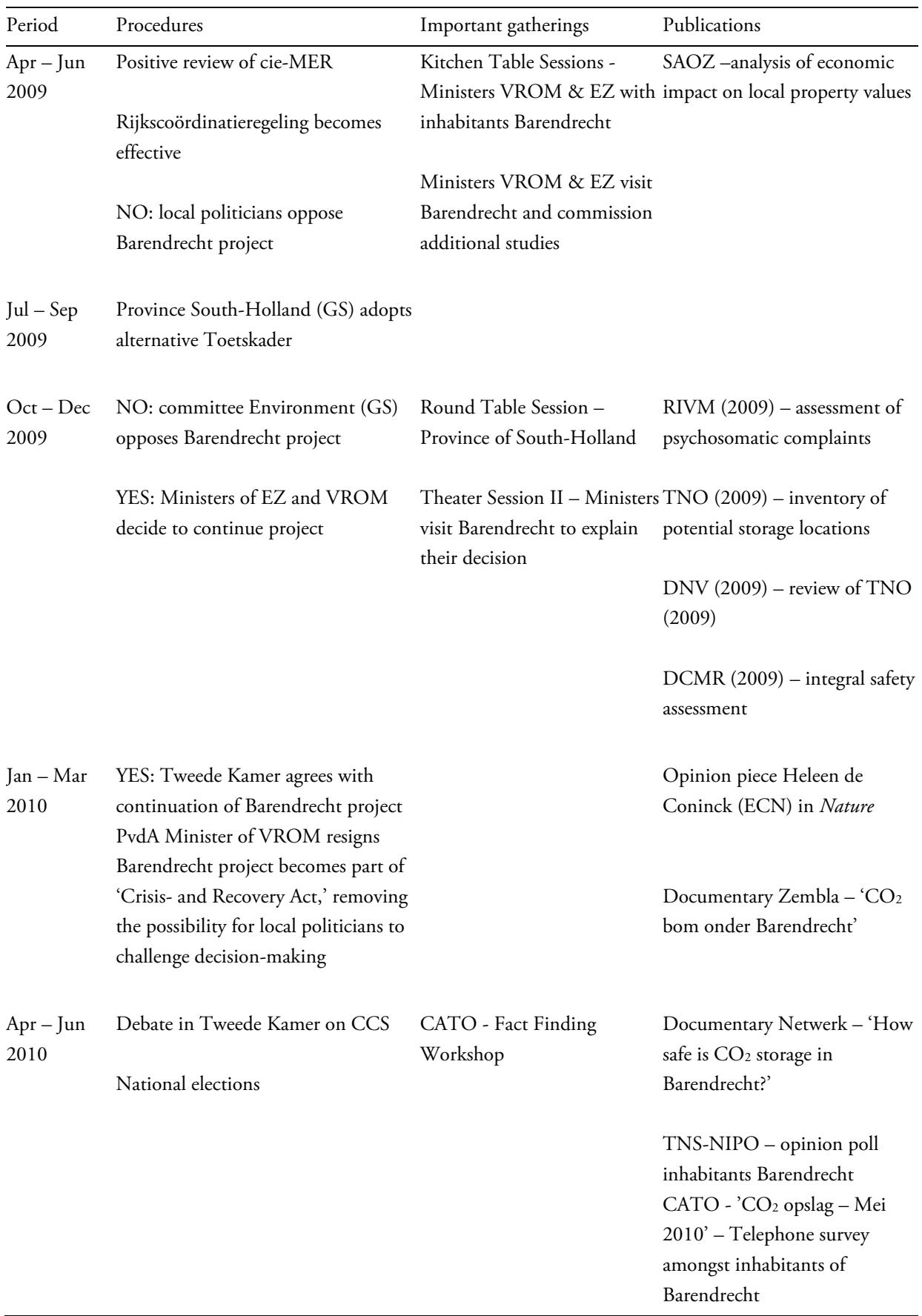




\begin{tabular}{llll}
\hline Period & Procedures & Important gatherings & Publications \\
\hline Jul - Sep & $\begin{array}{l}\text { Period for public consultation and } \\
\text { comments on plan-MER }\end{array}$ & Walk-in Session I & Plan-MER Barendrecht \\
& $\begin{array}{l}\text { Van der Hoeven (EZ) responds to } \\
\text { questions from Vaste Commissie EZ }\end{array}$ & Walk-in Session II & \\
Oct - Dec & $\begin{array}{l}\text { End of period for public consultation } \\
\text { plan-MER }\end{array}$ \\
& $\begin{array}{l}\text { New national government installed } \\
\text { Cie-MER comments positive on } \\
\text { plan-MER }\end{array}$ \\
& $\begin{array}{l}\text { NO: new Minister of EZ (CDA) } \\
\text { cancels Barendrecht project due to } \\
\text { time delays and lack of public support }\end{array}$ \\
\hline
\end{tabular}




\section{APPENDIX C - CHRONOLOGY OF EPA'S STANDARD-SETTING PROCESS}

\begin{tabular}{|c|c|c|}
\hline Year & Federal level & State level - Illinois \\
\hline 2005 & & $\begin{array}{l}\text { Tenaska Inc proposes } \$ 3.5 \text { billion new coal-fired power } \\
\text { plant: the 'Taylorville Energy Center' (TEC) }\end{array}$ \\
\hline 2007 & $\begin{array}{l}\text { Supreme Court rules that EPA has } \\
\text { authority to regulate } \mathrm{CO}_{2} \text { emissions } \\
\text { under Clean Air Act }\end{array}$ & Construction permit TEC granted \\
\hline 2009 & $\begin{array}{l}\text { Inauguration of President Obama; } \\
\text { EPA classifies } \mathrm{CO}_{2} \text { as a regulated } \\
\text { pollutant (Endangerment Finding) }\end{array}$ & $\begin{array}{l}\text { Illinois introduces Clean Coal Portfolio Standard } \\
\text { Tenaska applies for DOE’s Loan Guarantee worth over } \\
\$ 2.5 \text { billion and promises to use partial CCS. }\end{array}$ \\
\hline 2010 & $\begin{array}{l}\text { EPA starts deliberations on } \\
\text { Performance Standard for electricity } \\
\text { generating units }\end{array}$ & $\begin{array}{l}\text { Tenaska submits Facility Cost Report to Illinois } \\
\text { Commerce Commission (ICC) } \\
\text { DOE grants Tenaska } \$ 417 \text { million tax credit; }\end{array}$ \\
\hline \multirow[t]{3}{*}{2011} & $\begin{array}{l}\text { EPA organizes informal Listening } \\
\text { Sessions on Performance Standard }\end{array}$ & $\begin{array}{l}\text { Tenaska applies for air permit } \\
\text { ICC reviews economic risks of TEC and Tenaska's } \\
\text { promise to use CCS }\end{array}$ \\
\hline & $k$ & $\begin{array}{l}\text { Illinois-EPA qualifies CCS as not technically feasible for } \\
\text { TEC }\end{array}$ \\
\hline & $\begin{array}{l}\text { EPA urges Illinois-EPA to explain its } \\
\text { decision }\end{array}$ & \\
\hline \multirow[t]{3}{*}{2012} & $\begin{array}{l}\text { EPA publishes draft standard }(1,100 \mathrm{lbs} \\
\left.\mathrm{CO}_{2} / \mathrm{MWh}\right) \text {, receiving over } 2.5 \text { million } \\
\text { public comments }\end{array}$ & \\
\hline & $\begin{array}{l}\text { Environmental NGOs challenge } \\
\text { Tenaska's permit in front of EPA's } \\
\text { Environmental Appeals Board }\end{array}$ & Illinois-EPA grants air permit without CCS requirement \\
\hline & $\begin{array}{l}\text { EPA urges Illinois-EPA to reconsider its } \\
\text { permit decision }\end{array}$ & Illinois-EPA withdraws permit TEC \\
\hline 2013 & $\begin{array}{l}\text { EPA withdraws proposed Performance } \\
\text { Standard and circulates draft of a } \\
\text { revised version for inter-Agency review; } \\
\text { EPA's Science Advisory Board asks for } \\
\text { review of supporting science }\end{array}$ & Tenaska cancels TEC \\
\hline
\end{tabular}




\begin{tabular}{lll}
\hline Year & Federal level & State level - Illinois \\
\hline 2014 & EPA proposes alternative Performance \\
& $\begin{array}{l}\text { Standard of } 1,100 \mathrm{lbs} \mathrm{CO}_{2} / \mathrm{MWh}, \\
\text { receiving over } 2 \text { million public } \\
\text { comments. }\end{array}$ \\
& $\begin{array}{l}\text { EPA publishes final performance } \\
\text { standard: } 1,400 \mathrm{lbs} \mathrm{CO}_{2} / \mathrm{MWh}\end{array}$ \\
\hline
\end{tabular}




\section{APPENDIX D - SELECTION OF US COMMITTEE MEETINGS ON CCS}

\begin{tabular}{|c|c|c|c|c|}
\hline Date & Committee & $\begin{array}{l}\text { Chair(s) / } \\
\text { sponsor of } \\
\text { bill }\end{array}$ & Title & Angle of critique \\
\hline $\begin{array}{l}\text { Jul } \\
2013\end{array}$ & $\begin{array}{l}\text { Subcommittee Energy / } \\
\text { House Committee on } \\
\text { Science, Space \& } \\
\text { Technology }\end{array}$ & R-Wyoming & $\begin{array}{l}\text { The future of coal: } \\
\text { Utilizing America's } \\
\text { abundant energy } \\
\text { resources }\end{array}$ & $\begin{array}{l}\text { Effectiveness of domestic GHG regulations } \\
\text { questioned (vis-à-vis China) and concern } \\
\text { raised about economic impact of proposed } \\
\text { performance standard on coal sector }\end{array}$ \\
\hline $\begin{array}{l}\text { Oct } \\
2013\end{array}$ & $\begin{array}{l}\text { Subcommittees Energy } \& \\
\text { Environment / } \\
\text { House Committee on } \\
\text { Science, Space \& } \\
\text { Technology }\end{array}$ & $\begin{array}{l}\text { R-Texas } \\
\text { R-Utah } \\
\text { R-Wyoming }\end{array}$ & $\begin{array}{l}\text { EPA Power Plant } \\
\text { Regulations: is the } \\
\text { technology ready? }\end{array}$ & $\begin{array}{l}\text { CCS technologies are not ready, according } \\
\text { to consulted industry experts }\end{array}$ \\
\hline $\begin{array}{l}\text { Nov } \\
2013\end{array}$ & $\begin{array}{l}\text { Subcommittee Energy \& } \\
\text { Power / House Committee } \\
\text { on Energy \& Commerce }\end{array}$ & R-Michigan & $\begin{array}{l}\text { EPA's proposed } \\
\text { GHG standards for } \\
\text { new power plants }\end{array}$ & $\begin{array}{l}\text { It is legally prohibited to refer to EPAct05- } \\
\text { funded projects to determine that CCS is } \\
\text { 'adequately demonstrated' }\end{array}$ \\
\hline $\begin{array}{l}\text { Feb } \\
2014\end{array}$ & $\begin{array}{l}\text { Subcommittee } \\
\text { Environment / } \\
\text { House Committee on } \\
\text { Science, Space \& } \\
\text { Technology }\end{array}$ & $\begin{array}{l}\text { R-Texas } \\
\text { R-Arizona }\end{array}$ & $\begin{array}{l}\text { H.R. } 4012 \text { - Secret } \\
\text { Science Reform Act }\end{array}$ & $\begin{array}{l}\text { EPA should be prohibited to issue } \\
\text { environmental regulations, unless all } \\
\text { scientific and technical information is } \\
\text { specified and made publicly available, so that } \\
\text { independent analysis and reproduction of } \\
\text { research results is possible. } \\
\text { (Passed by the House in November } 2014 \\
\text { and referred to Senate Committee.) }\end{array}$ \\
\hline $\begin{array}{l}\text { Feb } \\
2014\end{array}$ & $\begin{array}{l}\text { Subcommittee Energy \& } \\
\text { Power / } \\
\text { House Committee on } \\
\text { Energy \& Commerce }\end{array}$ & $\begin{array}{l}\text { R-Kentucky } \\
\text { D-West } \\
\text { Virginia }\end{array}$ & $\begin{array}{l}\text { H.R. } 3826-\text { the } \\
\text { Electricity Security } \\
\text { and Affordability } \\
\text { Act }\end{array}$ & $\begin{array}{l}\text { Alternative standard of evidence: NSPS is } \\
\text { only acceptable if it is achieved for the } \\
\text { period of one year by at least six different } \\
\text { power plants in the US } \\
\text { (Passed by the House in March 2014, but } \\
\text { never submitted to Senate, after President } \\
\text { Obama indicated that he would veto the } \\
\text { bill.) }\end{array}$ \\
\hline $\begin{array}{l}\text { Mar } \\
2014\end{array}$ & $\begin{array}{l}\text { Subcommittees Energy \& } \\
\text { Environment / } \\
\text { House Committee on } \\
\text { Science, Space \& } \\
\text { Technology }\end{array}$ & $\begin{array}{l}\text { R-Arizona } \\
\text { R-Wyoming }\end{array}$ & $\begin{array}{l}\text { Science of capture } \\
\text { and storage: } \\
\text { Understanding } \\
\text { EPA's carbon rules }\end{array}$ & $\begin{array}{l}\text { CCS is expensive and unavailable. It would } \\
\text { not be adopted without regulatory force. } \\
\text { EPA is therefore pursuing an unacceptable } \\
\text { policy of picking technological winners and } \\
\text { losers }\end{array}$ \\
\hline
\end{tabular}




\begin{tabular}{lll}
\hline Date Committee & Chair(s) / Title Angle of critique \\
& sponsor of \\
& bill
\end{tabular}

Apr Subcommittee Energy \& R-Kentucky Review EPA's Fiscal Given that CCS is not yet commercially

2014 Power \& Environment \& R-Illinois Year 2015 Budget viable (according to utility sector), EPA's

Economy /

Request

performance standard entails high economic

House Committee on costs and negatively impacts grid reliability /

Energy \& Commerce

energy security

Feb House Committee on

2015 Science, Space \&

Technology

R-Oklahoma H.R. 1029 - EPA Change to SAB appointment process, in

Science Advisory order to strengthen role of industry scientists

Board Reform Act in the regulatory process

Feb Senate Committee on

R-Oklahoma EPA's proposed CCS is not economically feasible yet

2015 Environment \& Public $\mathrm{CO}_{2}$ regulations for (underlined by cancellation of the Works power plants

FutureGen project due to cost overruns) 


\section{References}

Adams, E., \& Caldeira, K. (2008). Ocean Storage of CO2. Elements, 4(5), 319-324.

Ahmad, M., Osch, M., Buit, L., Florisson, O., Hulsbosch-Dam, C., Spruijt, M., \& Davolio, F. (2013). Study of the thermohydraulics of $\mathrm{CO}_{2}$ discharge from a high pressure reservoir. International Journal of Greenhouse Gas Control, 19, 63-73. http://doi.org/10.1016/j.ijggc.2013.08.004

Ale, B. (2005). Tolerable or Acceptable: A Comparison of Risk Regulation in the United Kingdom and in the Netherlands. Risk Analysis, 25(2), 231-241. http://doi.org/10.1111/j.1539-6924.2005.00585.x

Anderson, B. (1983). Imagined Communities. Reflections on the Origin and Spread of Nationalism. London: Verso.

Arts, R., Chadwick, R., \& Eiken, O. (2004). Recent time lapse seismic data again show NO indication of leakage at Sleipner CO2 injection site. Seventh International Conference on Greenhouse Gas Control Technologies, Vancouver. Retrieved from http://www.researchgate.net/publication/228943730_Recent_time-lapse_seismic_ data_show_no_indication_of_leakage_at_the_Sleipner_CO2-injection_site

Ashworth, P., Bradbury, J., Feenstra, Y., Greenberg, S., Hund, G., Mikunda, T., \& Wade, S. (2010). Communication, project planning and management for carbon capture and storage projects: An international comparison. CSIRO \& Global CCS Institute.

Bachu, S. (2008). $\mathrm{CO}_{2}$ storage in geological media: Role, means, status and barriers to deployment. Progress in Energy and Combustion Science, 34(254-273).

Bachu, S., Bonijoly, D., Bradshaw, J., Burruss, R., Holloway, S., Christensen, N. P., \& Mathiassen, O. (2007). $\mathrm{CO}_{2}$ storage capacity estimation: Methodology and gaps. International Journal of Greenhouse Gas Control, 1(4), 430-443.

Bäckstrand, K., Meadowcroft, J., \& Oppenheimer, M. (2011). The politics and policy of carbon capture and storage: Framing an emergent technology. Global Environmental Change-Human and Policy Dimensions, 21(2), 275-281.

Bal, R. (1999). Grenzenwerk: Over het organiseren van normstelling voor de arbeidsplek. University of Twente.

Benson, S. (2007). Confidence building in CCS: The role of industrial analogues.

Benson, S., Hepple, R., Apps, J., Tsang, C., \& Lippmann, M. (2002). Lessons Learned from Natural and Industrial Analogues for Storage of Carbon Dioxide in Deep Geological Formations. Lawrence Berkeley National Laboratory.

Bijker, W. E. (1995). Of bicycles, bakelites, and bulbs: toward a theory of sociotechnical change. London: MIT Press.

Bijker, W. E., Bal, R., \& Hendriks, R. (2009). The Paradox of Scientific Authority: The Role of Scientific Advice in Democracies. London: MIT Press.

Bijker, W. E., Hughes, T., \& Pinch, T. (1987). The social construction of technological systems: New directions in the sociology and history of technology. Cambridge: MIT Press. 
Bimber, B. (1990). Karl Marx and the Three Faces of Technological Determinism. Social Studies of Science, 20(2), 333-351. http://doi.org/10.1177/030631290020002006

Blok, K., Hendriks, C., \& Turkenburg, W. (1989). The role of carbon dioxide removal in the reduction of the greenhouse effect.

Boehmer-Christiansen, S. (2003). Science, Equity, and the War against Carbon. Science, Technology \& Human Values, 28(1), 69-92.

Boholm, A. (2008). The Public Meeting as a Theatre of Dissent: Risk and Hazard in Land Use and Environmental Planning. Journal of Risk Research, 11(1), 119 - 140.

Borup, M., Brown, N., Konrad, K., \& Van Lente, H. (2006). The sociology of expectations in science and technology. Technology Analysis \& Strategic Management, 18(3/4), 285-298.

Bouder, F., Slavin, D., \& Löfstedt, R. (Eds.). (2009). The Tolerability of Risk: A New Framework for Risk Management. London: Earthscan.

Bowker, G. (1994). Science on the run: Information management and industrial geophysics at Schlumberger, 1920-1940. Cambridge, MA: MIT Press.

Bressers, H., \& de Bruijn, T. (2005). Environmental Voluntary Agreements in the Dutch Context. Environment \& Policy, 43, 261-281.

Brown, M. (2009). Science in democracy: Expertise, institutions, and representation. Cambridge, MA: MIT Press.

Brown, N., \& Michael, M. (2003). A Sociology of Expectations: Retrospecting Prospects and Prospecting Retrospects. Technology Analysis \& Strategic Management, 15(1), 3-18.

Bryngelsson, M., \& Hansson, A. (2009). Energy policy on shaky ground? A study of CCS-scenarios. Energy Procedia, 1(1), 4673-4680.

Busch, L. (2011). Standards: Recipes for reality. London: MIT Press.

Callon, M. (1998). An essay on framing and overflowing: economic externalities revisited by sociology. The Sociological Review, 46(S1), 244-269. http://doi.org/10.1111/j.1467-954X.1998.tb03477.x

Callon, M. (2009). Civilizing Markets: Carbon Trading Between In Vitro and In Vivo Experiments. Accounting, Organizations and Society (Vol. 34, pp. 535-548).

Callon, M., Lascoumes, P., \& Barthe, Y. (2001). Agir dans un monde incertain. Essai sur la démocratie technique. Paris: Le Seuil.

Callon, M., Lascoumes, P., \& Barthe, Y. (2009). Acting in an uncertain world: An essay on technical democracy. Cambridge: MIT Press.

Cass, L. (2006). The failures of American and European climate policy: International norms, domestic politics, and unachievable commitments. New York: State University of New York Press.

Castells, M. (2010). The rise of the network society. Oxford: Wiley-Blackwell.

CATO. (2009). Catching carbon to clear the skies: Experiences and highlights of the Dutch R\&D programme on CCS. Utrecht: Dutch CATO Program.

Cavanagh, A., Haszeldine, R., \& Blunt, M. (2010). Open or closed? A discussion of the mistaken assumptions in the Economides pressure analysis of carbon sequestration. Journal of Petroleum Science and Engineering, 74(1-2), 107-110.

Chadwick, A., Smith, D., Hodrien, C., Hovorka, S., Mackay, E., Mathias, S.,... Davidson, C. (2010). The realities of storing carbon dioxide - A response to $\mathrm{CO}_{2}$ storage capacity issues raised by Ehlig-Economides and Economides. Available from Nature Precedings <http://dx.doi.org/10.1038/npre.2010.4500.1>.

Chappin, E., \& Dijkema, G. (2009). On the impact of $\mathrm{CO}_{2}$ emission-trading on power generation emissions. Technological Forecasting \& Social Change, (76), 359-370.

Cole, K., Stegen, G., \& Spencer, D. (1993). The capacity of the deep oceans to absorb carbon dioxide. Energy Conversion and Management, 34(9-11), 991-998.

Collins, H. (1985). Changing order: Replication and induction in scientific practice. Chicago: University of Chicago Press. 
Collins, H., \& Evans, R. (2002). The third wave of science studies: Studies of expertise and experience. Social Studies of Science, 32(2), 235-296.

Collins, H., \& Evans, R. (2007). Rethinking expertise. Chicago: University of Chicago Press.

Collins, H., \& Pinch, T. (2010). The Golem at Large: What you should know about technology. Cambridge: Cambridge University Press.

Corry, O., \& Riesch, H. (2012). Beyond "for or against": Environmental NGO-evaluations of CCS as a climate change solution. In N. Markusson, S. Shackley, \& B. Evar (Eds.), The social dynamics of carbon capture and storage: Understanding CCS representations, governance and innovation (pp. 91-108). London: Routledge.

Daamen, D., Terwel, B., Mors, E., Reiner, D., Schumann, D., Anghel, S.,... Ziogou, F. (2011). Scrutinizing the impact of CCS communication on opinion quality: Focus group discussions versus Information-Choice Questionnaires: Results from experimental research in six countries. Energy Procedia, 4(0), 6182-6187.

Damen, K., Faaij, A., \& Turkenburg, W. (2006). Health, Safety and Environmental Risks of Underground $\mathrm{CO}_{2}$ Storage - Overview of Mechanisms and Current Knowledge. Climatic Change, 74(1), 289-318.

David, P. (1985). Clio and the Economics of QWERTY. The American Economic Review, 75(2), 332-337.

Davies, L., Uchitel, K., \& Ruple, J. (2013). Understanding barriers to commercial-scale carbon capture and sequestration in the United States: An empirical assessment. Energy Policy, 59, 745-761. http://doi.org/10.1016/j.enpol.2013.04.033

Dean, M. (2010). Governmentality: Power and rule in modern society. London: SAGE.

De Best-Waldhober, M., \& Daamen, D. (2006). Public perceptions and preferences regarding large scale implementatino of six $\mathrm{CO}_{2}$ capture and storage technologies. Leiden University.

De Best-Waldhober, M., Daamen, D., Ramirez Ramirez, A., Faaij, A., Hendriks, C., \& de Visser, E. (2009). Informed public opinions on CCS in comparison to other mitigation options. Energy Procedia, 1(1), 4795-4802.

de Coninck, H. (2008). The international race for $\mathrm{CO}_{2}$ capture and storage: And the winner is... ? FACET Commentary, (12). Retrieved from www.facet-online.org

de Coninck, H. (2010). Advocacy for carbon capture and storage could arouse distrust. Nature, 463(7279), 293293.

de Coninck, H., Anderson, J., Curnow, P., Flach, T., Flagstad, O., Groenenberg, H.,... Shackley, S. (2006). Acceptability of $\mathrm{CO}_{2}$ capture and storage: A review of legal, regulatory, economic and social aspects of $\mathrm{CO}_{2}$ capture and storage. ECN-C-06-026: ACCSEPT Project.

de Coninck, H., Flach, T., Curnow, P., Richardson, P., Anderson, J., Shackley, S.,... Reiner, D. (2009). The acceptability of $\mathrm{CO}_{2}$ capture and storage (CCS) in Europe: An assessment of the key determining factors: Part 1. Scientific, technical and economic dimensions. International Journal of Greenhouse Gas Control, 3(3), 333-343.

de Jong, J., Weeda, E., Westerwoudt, T., \& Correljé, A. (2005). Van bonzen en polders via markten naar Brussel zonder koolstof. Clingendael International Energy Programme.

Demeritt, D. (2006). Science studies, climate change and the prospects for constructivist critique. Economy and Society, 35(3), 4530479.

de Vos, R. (Ed.). (2014). Linking the chain: Integrated CATO2 knowledge prepares for the next step in $\mathrm{CO}_{2}$ capture \& storage. Utrecht: CATO2.

Dijstelbloem, H., \& Hagendijk, R. (2011). Onzekerheid troef: Het betwiste gezag van de wetenschap. Amsterdam: Van Gennep.

Dunlap, R., \& Mertig, A. (Eds.). (1992). American environmentalism: the US environmental movement, 19701990. London: Routledge.

Ecofys. (2007). Making large-scale CCS in the Netherlands work : An agenda for 2007 - 2020. Ecofys.

Edgerton, D. (2006). The shock of the old. London: Profile Books.

Egyedi, T. (2000). The standardised container: Gateway technologies in cargo transport. In M. Holler \& E. Niskanen (Eds.), EURAS Yearbook of Standardisation (pp. 231-262). Munich: Accedo. 
Epstein, S. (1995). The construction of lay expertise: AIDS activism and the forging of credibility in the reform of clinical trials. Science, Technology \& Human Values, 20(4), 408-437.

Evar, B. (2011). Conditional inevitability: Expert perceptions of carbon capture and storage uncertainties in the UK context. Energy Policy, 39(6), 3414-3424.

Evar, B., \& Shackley, S. (2012). Technology management in the face of scientific uncertainty: a case study of the CCS Test Centre Mongstad. In N. Markusson, S. Shackley, \& B. Evar (Eds.), The social dynamics of carbon capture and storage: Understanding CCS representations, governance and innovation (pp. 172-188). London: Earthscan.

EZ. (2008). Energierapport 2008. Ministry of Economic Affairs.

Ezrahi, Y. (1990). The descent of Icarus: Science and transformation of contemporary democracy. Cambridge: Hardvard University Press.

Ezrahi, Y. (2004). Science and the political imagination in contemporary democracies. In S. Jasanoff (Ed.), States of Knowledge: The Co-Production of Science and the Social Order (pp. 254-273). London: Routledge.

Ezrahi, Y. (2012). Imagined Democracies: Necessary Political Fictions. Cambridge: Cambridge University Press.

Faaij, A. (2002). Transforming the energy system of the Netherlands: Two visions on reaching $80 \%$ emission reduction by 2050. In M. Kok, W. Vermeulen, A. Faaij, \& D. De Jager (Eds.), Global warming and social innovation: The challenge of a climate-neutral society (pp. 17-38). London: Earthscan.

Fairclough, N. (2010). Critical Discourse Analysis: The Critical Study of Language. London: Pearson.

Feenstra, C., Mikunda, T., \& Brunsting, S. (2010). What happened in Barendrecht?! Case study on the planned onshore carbon dioxide storage in Barendrecht, the Netherlands. ECN Policy Studies, 44.

Felt, U. (2013). Keeping Technologies Out: Sociotechnical imaginaries and the formation of a national technopolitical identity. University of Vienna: Department of Social Studies of Science.

Felt, U., \& Wynne, B. (2007). Taking European knowledge society seriously (Report to the Expert Group on Science and Governance to the Science, Economy and Society Directorate, DG for Research). Brussels: European Commission.

Figueroa, J., Fout, T., Plasynski, S., McIlvried, H., \& Srivastava, R. (2008). Advances in $\mathrm{CO}_{2}$ capture technology-The U.S. Department of Energy's Carbon Sequestration Program. International Journal of Greenhouse Gas Control, 2(1), 9-20. http://doi.org/10.1016/S1750-5836(07)00094-1

Fiorino, D. (1990). Citizen participation and environmental risk: A survey of institutional mechanisms. Science, Technology and Human Values, 15(2), 226-243.

Fischer, F. (2005). Are scientists irrational? Risk assessment in practical reason. In M. Leach, I. Scoones, \& B. Wynne (Eds.), Science and Citizens: Globalization and the challenge of engagement (pp. 54-65). London: Zed Books.

Fischer, F., \& Forester, J. (1993). The argumentative turn in policy analysis and planning. London: Duke University Press.

Fischer, S. (2012). Carbon capture and storage: the Europeanization of a technology in Europe's energy policy? In F. Morata \& S. Sandoval (Eds.), European Energy Policy: An Environmental Approach (pp. 85-96). Cheltenham: Edward Elgar Publishing.

Fitzgerald, J. (2012). The Messy Politics of "Clean Coal” - The Shaping of a Contested Term in Appalachia's Energy Debate. Organization \& Environment, 25(4), 437-451. http://doi.org/10.1177/1086026612466091

Folger, P. (2013a). Carbon Capture and Sequestration: Research, Development, and Demonstration at the US Department of Energy (No. R42496). Congressional Research Service.

Folger, P. (2013b). FutureGen: A brief history and issues for Congress. Washington DC: Congressional Research Service.

Freund, P., \& Ormerod, W. (1997). Progress toward storage of carbon dioxide. Energy Conversion and Management, 38, Supplement(0), S199-S204.

Fuller, S. (2013). Beyond the precautionary principle? The Guardian (online Version), 10 July 2013.

GCCSI. (2011). The Global Status of CCS: 2011. Canberra, Australia: Global CCS Institute. 
Gezondheidsraad. (2008). Prudent precaution. Health Council of the Netherlands.

Gibbins, J., \& Chalmers, H. (2008). Preparing for global rollout: A “developed country first" demonstration programme for rapid CCS deployment. Energy Policy, 36, 501-507.

Giddens, A. (2009). The politics of climate change. Cambridge: Polity Press.

Gieryn, T. (1983). 'Boundary work and the demarcation of science from non-science: strains and interests in professional ideologies of scientists.' American Sociological Review, 48: 781-795.

Gieryn, T. (1995). Boundaries of science. In S. Jasanoff, G. Markle, J. Peterson, \& T. Pinch (Eds.), Handbook of science and technology studies. London: Sage.

Gieryn, T. (1999). Cultural boundaries of science: Credibility on the line. Chicago: University of Chicago Press.

Gjefsen, M. (2013). Carbon Cultures: Technology Planning for Energy and Climate in the US and EU. Science \& Technology Studies, 26, 63-81.

Goffman, E. (1974). Frame analysis: An essay on the organization of experience. Cambridge: Harvard University Press.

Green4Sure. (2007). Het groene energieplan voor Nederland. ABVAKABO, FNV, Greenpeace, Milieudefensie, Stichting Natuur en Milieu, Wereld Natuur Fonds.

Guston, D. (2001). Boundary organizations in environmental policy and science. Science, Technology \& Human Values, 26(4), 399-500.

Haas, P. (1992). Introduction: epistemic communities and international policy coordination. International Organization, 46(1), 1-35.

Hagendijk, R., \& Irwin, A. (2006). Public deliberation and governance: Engaging with science and technology in contemporary Europe. Minerva, 44, 167-184.

Hajer, M. (2009). Authoritative governance: Policy-making in the age of mediatization. Oxford: Oxford University Press.

Halffman, W. (1998). Standardization as a trust device. In R. Bal \& W. Halffman (Eds.), The politics of chemical risk: Scenarios for a regulatory future (pp. 265-291). Amsterdam: Springer Netherlands.

Halffman, W. (2003). Boundaries of regulatory science: Eco/toxicology and aquatic hazards of chemics in the US, England, and the Netherlands, 1970-1995. Amsterdam: University of Amsterdam.

Hamilton, M., Herzog, H., \& Parsons, J. (2009). Cost and US public policy for new coal power plants with carbon capture and sequestration. Energy Procedia, 1(1), 4487.

Hanf, K., \& van de Gronden, E. (1998). The Netherlands: Joint regulation and sustainable development. In K. Hanf \& A. Jansen (Eds.), Governance and environment in Western Europe: Politics, policy and administration (pp. 152-180). Harlow: Longman.

Hansson, A. (2012). Colonizing the future: the case of CCS. In N. Markusson, S. Shackley, \& B. Evar (Eds.), The social dynamics of carbon capture and storage: Understanding CCS representations, governance and innovation (pp. 74-90). London: Routledge.

Hansson, A., \& Bryngelsson, M. (2009). Expert opinions on carbon dioxide capture and storage-A framing of uncertainties and possibilities. Energy Policy, 37(6), 2273-2282.

Hawkins, D., Lashof, D., \& Williams, R. (2006). What to do about coal? Scientific American, 295, 68-75.

Hecht, G. (1998). The radiance of France: Nuclear power and national identity after World War II. London: MIT Press.

Heilbron, B., Mommers, J., Muntz, T., \& De Zeeuw, H. (2013). Nog een eeuw fossiel: Land van gas en kolen (Onderzoeksdossier). De Groene Amsterdammer, 136(4), 22-33.

Heinzerling, I. (2012). Climate change at EPA. Florida Law Review, 64(2), 14.

Held, D. (2006). Models of democracy. London: Stanford University Press.

Hendriks, C. (1994). Carbon dioxide removal from coal-fired power plants. Dordrecht: Kluwer Publishing.

Hendriks, C. (2008). On inclusion and network governance: The democratic disconnect of Dutch energy transitions. Public Administration, 86, 1009-1031. 
Hermans, M., Fox, T., \& van Asselt, M. (2012). Risk governance. In S. Roeser, R. Hillerbrand, P. Sandin, \& M. Peterson (Eds.), Handbook of risk theory (pp. 1093-1117). London: Springer.

Herzog, H. (2009). Carbon Dioxide Capture and Storage. In D. Helm \& C. Hepburn (Eds.), The economics and politics of climate change (pp. 263-283). Oxford: Oxford University Press.

Herzog, H., Adams, E., Akai, M., Alendal, G., Golmen, L., Haugan, P.,... Wong, C. (2000). Update on the international experiment on $\mathrm{CO}_{2}$ ocean sequestration. In D. Williams, R. A. Durie, P. McMullan, C. A. J. Paulson, \& A. Y. Smith (Eds.), Proceedings of the 5th International Conference on Greenhouse Gas Control Technologies (pp. 399-404). Cairns (Australia).

Higgins, V., \& Larner, W. (Eds.). (2010). Calculating the social: Standards and the reconfiguring of governing. London: Palgrave MacMillan.

Hilgartner, S. (2000). Science on stage: Expert advice as public drama. Stanford: Stanford University Press.

Hilgartner, S. (2004). The Credibility of Science on Stage. Social Studies of Science, 34(3), 443-452. http://doi.org/10.1177/0306312704043694

Hisschemöller, M., Van de Kerkhof, M., Kok, M., \& Folkert, R. (2002). Climate OptiOns for the Long term COOL: Stakeholders' views on 80 per cent emission reduction. In M. Kok, W. Vermeulen, A. Faaij, \& D. De Jager (Eds.), Global warming and social innovation: The challenge of a climate-neutral society (pp. 196216). London: Earthscan.

Hoffmann, B., \& Szklo, A. (2011). Integrated gasification combined cycle and carbon capture: A risky option to mitigate $\mathrm{CO}_{2}$ emissions of coal-fired power plants. Applied Energy, 88(11), 3917-3929. http://doi.org/10.1016/j.apenergy.2011.04.002

Holloway, S. (1996). An overview of the Joule II project: The underground disposal of carbon dioxide. Energy Conversion and Management, 37(6-8), 1149-1154.

Holloway, S., Pearce, J., Hards, V., Ohsumi, T., \& Gale, J. (2007). Natural emissions of $\mathrm{CO}_{2}$ from the geosphere and their bearing on the geological storage of carbon dioxide. Energy, 32(7), 1194-1201.

Hoppe, R. (2010). Lost in translation? Boundary work in making climate change governable. In P. Driessen, P. Leroy, \& W. van Vierssen (Eds.), From Climate Change to Social Change: Perspectives on Science-Policy Interactions (pp. 109-130). Utrecht: International Books Utrecht.

Hoppe, R. (2011). Mark B. Brown, Science in Democracy. Expertise, Institutions, and Representation. Minerva, 49(3), 349-354. http://doi.org/10.1007/s11024-011-9179-x

Hughes, T. (1983). Networks of power: Electrification in Western Society, 1880-1930. Baltimore, MA: John Hopkins University Press.

Hulme, M. (2008). Geographical work at the boundaries of climate change. Transactions of the Institute of British Geographers, 33(1), 5-11.

Hulme, M. (2009). Why we disagree about climate change: Understanding controversy, inaction and opportunity. Cambridge: Cambridge University Press.

Hulsbosch-Dam, C., Spruijt, M., Necci, A., \& Cozzani, V. (2012). Assessment of particle size distribution in $\mathrm{CO}_{2}$ accidental releases. Journal of Loss Prevention in the Process Industries, 25(2), 254-262. http://doi.org/10.1016/j.jlp.2011.10.009

Hund, G., \& Greenberg, S. (2011). Dual-track CCS stakeholder engagement: Lessons learned from FutureGen in Illinois. Energy Procedia, 4(0), 6218-6225.

Huttunen, S., \& Hildén, M. (2014). Framing the Controversial: Geoengineering in Academic Literature. Science Communication, 36(1), 3-29. http://doi.org/10.1177/1075547013492435.

IEA-GHG. (1994). The disposal of carbon dioxide from fossil fuel fired power stations (No. IEAGHG/SR3). International Energy Agency - Greenhouse Gas R\&D Programme.

IPCC. (2005). Special Report on Carbon Dioxide Capture and Storage. Cambridge University Press.

Jasanoff, S. (1987). Contested Boundaries in Policy-Relevant Science. Social Studies of Science, 17(2), 195-230.

Jasanoff, S. (1990). The Fifth Branch: Science Advisers as Policymakers. Cambridge, MA: Harvard University Press. 
Jasanoff, S. (2002). Citizens at risk: Cultures of modernity in the US and EU. Science as Culture, 11(3), 363-380. Jasanoff, S. (2004). States of knowledge: The co-production of science and social order. London: Routledge.

Jasanoff, S. (2005). Designs on nature: Science and Democracy in Europe and the United States. Princeton: Princeton University Press.

Jasanoff, S. (2009). Governing innovation: The social contract and the democratic imagination. Seminar, 597.

Jasanoff, S. (2010a). A new climate for society. Theory, Culture \& Society, 27(2-3), 233-253.

Jasanoff, S. (2010b). Beyond calculation: A democratic response to risk. In A. Lakoff (Ed.), Disaster and the politics of intervention (pp. 14-40). New York: Columbia University Press.

Jasanoff, S. (2010c). Science in Democracy: Expertise, Institutions, and Representation (review article). Environmental Health Perspectives, 118(7), A312.

Jasanoff, S., \& Kim, S. (2009). Containing the Atom: Sociotechnical Imaginaries and Nuclear Power in the United States and South Korea. Minerva, 47(2), 119-146.

Jasanoff, S., \& Kim, S. (2013). Sociotechnical Imaginaries and National Energy Policies. Science as Culture, 22(2), 189-196. http://doi.org/10.1080/09505431.2013.786990

Jasanoff, S., Markle, G., Peterson, J., \& Pinch, T. (Eds.). (1995). Handbook of Science and Technology Studies. London: SAGE.

Johnsson, F., Reiner, D., Itaoka, K., \& Herzog, H. (2010). Stakeholder attitudes on Carbon Capture and Storage-An international comparison. International Journal of Greenhouse Gas Control, 4(2), 410-418.

Junginger, M., Suurs, R., Verbong, G., \& Schaeffer, G. (2010). Putting experiences curves in context: links to and between technology developments, market diffusion, learning mechanisms and systems innovation theory. In M. Junginger, W. van Sark, \& A. Faaij (Eds.), Technological Learning in the Energy Sector: Lessons for Policy, Industry and Science (pp. 36-47). London: Edward Elgar Publishing.

Kahneman, D., \& Tversky, A. (1972). Subjective probability: A judgment of representativeness. Cognitive Psychology, 3, 430-454.

Kasperson, R., Renn, O., Slovic, P., Brown, H., Emel, J., Globle, R.,... Ratick, S. (2000). The social amplification of risk: A conceptual framework. In P. Slovic (Ed.), The perception of risk. London: Earthscan.

Keith, D. (2000). Geoengineering the climate: History and prospect. Annual Review of Energy and the Environment, (25), 245-84.

Keith, D. (2009). Why Capture $\mathrm{CO}_{2}$ from the Atmosphere? Science, 325(5948), $1654-1655$. http://doi.org/10.1126/science. 1175680

Kemp, R. (2010). The Dutch energy transition approach. International Economics and Economic Policy, 7(2), 291316.

Kemp, R., Rotmans, J., \& Loorbach, D. (2007). Assessing the Dutch Energy Transition Policy: How Does it Deal with Dilemmas of Managing Transitions? Journal of Environmental Policy \& Planning, 9(3-4), 315-331.

Kickert, W. (2003). Beneath consensual corporatism: traditions of governance in the Netherlands. Public Administration, 81(1), 119-140.

Kjärstad, J., \& Johnsson, F. (2009). Ramp-up of large-scale CCS infrastructure in Europe. Energy Procedia, 1(1), 4201-4208.

Klinke, A., \& Renn, O. (2002). A new approach to risk evaluation and management: Risk-based, precautionbased and discourse-based strategies. Risk Analysis, 22(6), 1071-1094.

Kok, M., Vermeulen, W., Faaij, A., \& De Jager, D. (2002). Towards a climate-neutral society. In M. Kok, W. Vermeulen, A. Faaij, \& D. De Jager (Eds.), Global warming and social innovation: The challenge of a climateneutral society (pp. 1-15). London: Earthscan.

Koornneef, J. (2010). Shifting streams: On the health, safety and environmental impacts of carbon dioxide capture, transport and storage. 
Koornneef, J., Spruijt, M., Molag, M., Ramirez, A., Turkenburg, W., \& Faaij, A. (2010). Quantitative risk assessment of $\mathrm{CO}_{2}$ transport by pipelines-A review of uncertainties and their impacts. Journal of Hazardous Materials, 177(1-3), 12-27.

Kouw, M. (2012). Pragmatic constructions: Simulation and the vulnerability of technological cultures. University of Maastricht: PhD thesis.

Kuijper, M. (2011). Public acceptance challenges for onshore $\mathrm{CO}_{2}$ storage in Barendrecht. Energy Procedia, 4, 6226-6233.

Laird, F. (2013). Against Transitions? Uncovering Conflicts in Changing Energy Systems. Science as Culture, 22(2), 149-156. http://doi.org/10.1080/09505431.2013.786992

Latour, B. (1995). The'pedofil'of Boa Vista: A Photo-Philosophical Montage. Common Knowledge, 4(1), $144-187$.

Latour, B. (2005). Reassembling the Social: An introduction to Actor-Network Theory. Oxford: Oxford University Press.

Latour, B., \& Woolgar, S. (1986). Laboratory life: The construction of scientific facts. Chichester: Princeton University Press.

Leach, M., Scoones, I., \& Stirling, A. (2010). Dynamic sustainabilities: Technology, environment and social justice. London: Earthscan.

Levidow, L. (2013). EU criteria for sustainable biofuels: Accounting for carbon, depoliticising plunder. Geoforum, 44, 211-223.

Levidow, L., \& Papaioannou, T. (2013). State imaginaries of the public good: shaping UK innovation priorities for bioenergy. Environmental Science \& Policy, 30, 36-49. http://doi.org/10.1016/j.envsci.2012.10.008

Loorbach, D. (2010). Transition Management for Sustainable Development: A Prescriptive, Complexity-Based Governance Framework. Governance, 23(1), 161-183. http://doi.org/10.1111/j.1468-0491.2009.01471.x

Löfstedt, R. \& D. Vogel (2001). 'The changing character of regulation: A comparison between Europe and the United States'. Risk Analysis, 21(3), 399-416.

Lövbrand, E., Pielke Jr., R., \& Beck, S. (2011). A Democracy Paradox in Studies of Science and Technology. Science, Technology \& Human Values, 36(4), 474-496.

Lutsey, N., \& Sperling, D. (2008). America's bottom-up climate change mitigation policy. Energy Policy, 36(2), 673-685.

Lysen, E. (1996). The Trias Energica: Solar Energy Strategies for Developing Countries. Eurosun Conference (Freiburg).

Lysen, E. (2011). Varia Energetica. Utrecht Centre for Energy Research.

Mack, A., \& Spruijt, M. (2014). CFD Dispersion Investigation of $\mathrm{CO}_{2}$ Worst Case Scenarios Including Terrain and Release Effects. Energy Procedia, 51, 363-372. http://doi.org/10.1016/j.egypro.2014.07.043

MacKenzie, D. (2009). Constructing emission markets. In Material markets: How economic agents are constructed (pp. 137-176). Oxford: Oxford University Press.

MacKenzie, D. (2010). Constructing carbon markets: Learning from expertiments in the technopolitics of emissions trading schemes. In A. Lakoff (Ed.), Disaster and the politics of intervention (pp. 130-149). New York: Columbia University Press.

Malone, E., Bradbury, J., \& Dooley, J. (2009). Keeping CCS stakeholder involvement in perspective. Energy Procedia, 1(1), 4789-4794.

Malone, E., Dooley, J., \& Bradbury, J. (2010). Moving from misinformation derived from public attitude surveys on carbon dioxide capture and storage towards realistic stakeholder involvement. International Journal of Greenhouse Gas Control, 4(2), 419-425.

Marchetti, C. (1977). On geoengineering and the $\mathrm{CO}_{2}$ problem. Climatic Change, 1(1), 59-68.

Markusson, N., \& Haszeldine, S. (2009). Capture readiness'-lock-in problems for CCS governance. Energy Procedia, 1(1), 4625-4632. 
Markusson, N., \& Haszeldine, S. (2010). "Capture ready" regulation of fossil fuel power plants - Betting the UK's carbon emissions on promises of future technology. Energy Policy, 38(11), 6695-6702. http://doi.org/10.1016/j.enpol.2010.06.039

Markusson, N., Kern, F., Watson, J., Arapostathis, S., Chalmers, H., Ghaleigh, N.,... Russell, S. (2012). A sociotechnical framework for assessing the viability of carbon capture and storage technology. Technological Forecasting \& Social Change, 79, 903-918.

Markusson, N., Shackley, S., \& Evar, B. (2012). The social dynamics of carbon capture and storage: Understanding CCS representations, governance and innovation. London: Routledge.

Marres, N. (2007). The issues deserve more credit: Pragmatist contributions to the study of public involvement in controversy. Social Studies of Science, 37(5), 759-780.

McCright, A., \& Dunlap, R. (2011). The Politicization of Climate Change and Polarization in the American Public's Views of Global Warming, 2001-2010. Sociological Quarterly, 52(2), 155-194. http://doi.org/ 10.1111/j.1533-8525.2011.01198.x

McKinsey. (2009). Large scale roll out scenarios for CCS in the Netherlands: 2020-2050. Final report for the Ministry of Economic Affairs and the Ministry of Housing, Spatial Planning and the Environment.

Meadowcroft, J., \& Langhelle, O. (2010). Caching the carbon: The politics and policy of carbon capture and storage. London: Edward Elgar Pub.

Miller, C., Iles, A., \& Jones, C. (2013). The Social Dimensions of Energy Transitions. Science as Culture, 22(2), 135-148. http://doi.org/10.1080/09505431.2013.786989

Mitchell, R. C. (1989). From Conservation to Environmental Movement: the Development of the Modern Environmental Lobbies. In M. Lacey (Ed.), Government and Environmental Politics: Essays on Historical Developments Since WWII (pp. 81-113). Washington DC: Woodrow Wilson Center Press.

Nahuis, R., \& Lente, H. van. (2008). Where are the politics? Perspectives on democracy and technology. Science, Technology \& Human Values, 33(5), 559-581.

Narita, D. (2012). Managing uncertainties: The making of the IPCC's Special Report on Carbon Dioxide Capture and Storage. Public Understanding of Science, 21(1), 84-100.

Neele, F., Hendriks, C., \& Brandsma, R. (2009). Geocapacity: economic feasibility of CCS in networked systems. Energy Procedia, 1(1), 4217-4224.

Nicholls, T. (Ed.). (2007). Fundamentals of Carbon Capture and Storage Technology. Petroleum Economist Limited.

Nisbet, M. (2009). Communicating Climate Change: Why Frames Matter for Public Engagement. Environment: Science and Policy for Sustainable Development, 51(2), 12-23.

NMP3. (1998). Nationaal Milieubeleidsplan 3. Ministerie van Volkshuisvesting, Ruimtelijke Ordening en Milieubeheer.

NMP4. (2001). Een wereld en een wil - Werken aan duurzaamheid (Nationaal Milieubeleidsplan 4). Ministerie van Volkshuisvesting, Ruimtelijke Ordening en Milieubeheer.

Nowotny, H. (2014). Engaging with the political imaginaries of science: Near misses and future targets. Public Understanding of Science, 23(1), 16-20. http://doi.org/10.1177/0963662513476220

Nye, D. (1998). Consuming Power: A Social History of American Energies. Cambridge: MIT Press.

Nykvist, B. (2013). Ten times more difficult: Quantifying the carbon capture and storage challenge. Energy Policy, 55, 683-689. http://doi.org/10.1016/j.enpol.2012.12.026

Nylander, J. (2001). The construction of a market - A frame analysis of the liberalization of the electricity market in the European Union. European Societies, 3(3), 289-314. http://doi.org/10.1080/14616690120079341

Oreskes, N. (1998). Evaluation (not validation) of quantitative models. Environmental Health Perspectives, 106(6), 1453-1460.

Oreskes, N. (2000). Why believe a computer? Models, measures, and meaning in the natural world. In J. Schneiderman (Ed.), The earth around us: Maintaining a livable planet (pp. 70-82). San Francisco: Freeman \& Co.

Oreskes, N. (2004). Beyond the ivory tower: the scientific consensus on climate change. Science, 306(5702), 1686. 
Oreskes, N., \& Conway, E. (2004). Merchants of Doubt: How a Handful of Scientists Obscured the Truth on Issues from Tobacco Smoke to Global Warming. London: Bloomsbury Press.

Oreskes, N., Shrader-Frechette, K., \& Belitz, K. (1994). Verification, Validation, and Confirmation of Numerical Models in the Earth Sciences. Science, 263(5147), 641-646.

O'Riordan, T., \& Timmerman, P. (2001). Risk and imagining alternative futures. In J. Kasperson \& R. Kasperson (Eds.), Global environmental risk (pp. 429-450). New York: United Nations University Press.

Ormerod, W., Webster, I., Audus, H., \& Riemer, P. (1993). An overview of large scale $\mathrm{CO}_{2}$ disposal options. Energy Conversion and Management, 34(9-11), 833-840.

Parfomak, P. (2008). Carbon control in the US electricity sector: Key implementation uncertainties. Washington: Congressional Research Service.

Pasman, H., \& Fabiano, B. (2008). Trends, problems and outlook in risk assessments: Are we making progress? Presented at the International Conference on Safety and Environment in the Process Industry, Rome. Retrieved from www.aidic.it/CISAP3/webpapers/19Pasman.pdf

PBL. (2009). Milieubalans 2009. Planbureau voor de Leefomgeving.

PBL, \& ECN. (2011). Naar een schone economie in 2050 - Routes verkend (Hoe Nederland klimaatneutraal kan worden). Planbureau voor de Leefomgeving \& Energieonderzoek Centrum Nederland.

Pettenger, M. (2007). The Netherland's climate change policy: Constructing themselves / constructing climate change. In M. Pettenger (Ed.), The social construction of climate change: Power, knowledge, norms, discourses (pp. 51-74). London: Ashgate.

Pielke Jr., R. (2010). The climate fix: What scientists and politicians won't tell you about global warming. New York: Basic Books.

Pollak, M., Phillips, S., \& Vajjhala, S. (2011). Carbon capture and storage policy in the United States: A new coalition endeavors to change existing policy. Global Environmental Change, 21(2), 313-323.

Pollak, M., \& Wilson, E. (2009). Regulating Geologic Sequestration in the United States: Early Rules Take Divergent Approaches. Environmental Science \& Technology, 43(9), 3035-3041.

Poumadère, M., Bertoldo, R., \& Samadi, J. (2011). Public perceptions and governance of controversial technologies to tackle climate change: nuclear power, carbon capture and storage, wind, and geoengineering. Wiley Interdisciplinary Reviews: Climate Change, 2(5), 712-727.

Quartz, J. (2011). Constructing Agrarian Alternatives. How a creative dissent project engages with the vulnerable livelihood conditions of marginal farmers in South India. Phd Thesis: Maastricht University.

Rabe, B. (2008). States on Steroids: The Intergovernmental Odyssey of American Climate Policy. Review of Policy Research, 25(2), 105-128.

Ramirez, A., Hoogwijk, M., Hendriks, C., \& Faaij, A. (2008). Using a participatory approach to develop a sustainability framework for carbon capture and storage systems in The Netherlands. International Journal of Greenhouse Gas Control, 2(1), 136-154.

Randle, R. (1979). Forcing Technology: The Clean Air Act Experience. The Yale Law Journal, 88(8), 1713-1734. http://doi.org/10.2307/795694

Rayner, S., \& Malone, E. (Eds.). (1998). Human Choice \& Climate Change: Resources and Technology (vol.2). Columbus, Ohio: Battelle Memorial Institute.

Renn, O., \& Schweizer, P. (2009). Inclusive risk governance: concepts and application to environmental policy making. Environmental Policy and Governance, 19(3), 174-185.

Rip, A. (2003). Constructing Expertise: In a Third Wave of Science Studies? Social Studies of Science, 33(3), 419434.

Rip, A., \& Kemp, R. (1998). Technological change. In S. Rayner \& E. Malone (Eds.), Human choice and climate change (vol.2) (pp. 327-4-). Columbus, Ohio: Battelle Memorial Institute.

RMNO. (2010). De volle zaaiershanden. The Hague: Raad voor Ruimtelijk, Milieu- en Natuuronderzoek.

Roeser, S. (2011). Nuclear Energy, Risk, and Emotions. Philosophy and Technology, 1-5. 
Rotmans, J. (2011). Staat van de Energietransitie in Nederland. Rotterdam: Drift Institute.

Rotmans, J., \& Kemp, R. (2008). Detour Ahead: a response to Shove and Walker about the perilous road of transition management. Environment and Planning A, 40(4), 1006-1012.

Rotmans, J., Kemp, R., van Asselt, M., Geels, F., \& Molendijk, K. (2000). Transities \& transitiemanagement. De casus van een emissiearme energievoorziening. Maastricht: ICIS/MERIT.

Rotmans, J., \& van Asselt, M. (1996). Integrated assessment: A growing child on its way to maturity. Climatic Change, 34(3-4), 327-336. http://doi.org/10.1007/BF00139296

Rubin, E., Chen, C., \& Rao, A. (2007). Cost and performance of fossil fuel power plants with $\mathrm{CO}_{2}$ capture and storage. Energy Policy, 35(9), 4444-4454. http://doi.org/10.1016/j.enpol.2007.03.009

Rubin, E., Hounshell, D., Yeh, S., Taylor, M., Schrattenholzer, L., Riahi, K.,... Rao, S. (2004). The Effect of Government Actions on Environmental Technology Innovation: Applications to the Integrated Assessment of Carbon Sequestration Technologies (DE-FG02-00ER63037). Washington DC: Prepared for US Department of Energy.

Russell, S., Markusson, N., \& Scott, V. (2011). What will CCS demonstrations demonstrate? Mitigation and Adaptation Strategies for Global Change, 1-18.

Schmidt, S., \& Werle, R. (1998). Coordinating technology: Studies in the international standardization of telecommunications. Cambridge, MA: MIT Press.

Schön, D., \& Rein, M. (1994). Frame reflection: Toward the resolution of intractable policy controversies. New York: Basic books.

Scott, V. (2013). What can we expect from Europe's carbon capture and storage demonstrations? Energy Policy, $54,66-71$.

Shackley, S., \& Evar, B. (2012). Up and down with CCS. In N. Markusson, S. Shackley, \& B. Evar (Eds.), The social dynamics of carbon capture and storage: Understanding CCS representations, governance and innovation (pp. 149-171). London: Routledge.

Shackley, S., \& Gough, C. (2006). Carbon capture and its storage: An integrated assessment. London: Ashgate.

Shackley, S., McLachlan, C., \& Gough, C. (2004). The public perception of carbon dioxide capture and storage in the UK: results from focus groups and a survey. Climate Policy, 4(4), 377-398.

Shackley, S., Wynne, B., \& Waterton, C. (1996). Imagine complexity: The past, present and future potential of complex thinking. Futures, 28(3), 201-225.

Shapin, S., \& Schaffer, S. (1985). Leviathan and the Air-Pump: Hobbes, Boyle, and the Experimental Life. Princeton, N.J.: Princeton University Press.

Shove, E., \& Walker, G. (2007). CAUTION! Transitions ahead: politics, practice and sustainable transition management. Environment and Planning D: Society \& Space, 39(4), 763.

Slovic, P. (1993). Perceived risk, trust and democracy. Risk Analysis, 13(6), 675-682.

Smith, A., \& Kern, F. (2009). The transitions storyline in Dutch environmental policy. Environmental Politics, 18(1), 78-98.

Smith, W. (2009). Theatre of Use A Frame Analysis of Information Technology Demonstrations. Social Studies of Science, 39(3), 449-480. http://doi.org/10.1177/0306312708101978

Stehr, N. (2015). Climate policy: Democracy is not an inconvenience. Nature, 525, 449-450.

Steinberg, M., Cheng, H., \& Horn, F. (1984). Systems study for the removal, recovery and disposal of carbon dioxide from fossil fuel power plants in the US (No. DE85004499). Brookhaven National Laboratory.

Stenhouse, M., Gale, J., Herzog, H., \& Wilson, M. (2005). Regulatory aspects of deep (geological) $\mathrm{CO}_{2}$ storage.

Stenhouse, M., Gale, J., \& Zhou, W. (2009). Current status of risk assessment and regulatory frameworks for geological $\mathrm{CO}_{2}$ storage. Energy Procedia, 1(1), 2455-2462.

Stephens, J. (2009). Technology leader, policy laggard: CCS development for climate mitigation in the US political context. In J. Meadowcroft \& O. Langhelle (Eds.), Caching the carbon: The politics and policy of carbon capture and storage (pp. 22-49). Cheltenham: Edward Elgar. 
Stephens, J., Hansson, A., Liu, Y., de Coninck, H., \& Vajjhala, S. (2011). Characterizing the international carbon capture and storage community. Global Environmental Change, 21(2), 379-390.

Stephens, J., \& Jiusto, S. (2010). Assessing innovation in emerging energy technologies: Socio-technical dynamics of carbon capture and storage (CCS) and enhanced geothermal systems (EGS) in the USA. Energy Policy, 38(4), 2020-2031.

Stephens, J., \& Liu, Y. (2012). The evolving international CCS community. In N. Markusson, S. Shackley, \& B. Evar (Eds.), The social dynamics of carbon capture and storage: Understanding CCS representations, governance and innovation. London: Routledge.

Stephens, J., Markusson, N., \& Ishii, A. (2011). Exploring framing and social learning in demonstration projects of carbon capture and storage. Energy Procedia, 4(0), 6248-6255.

Stigson, P., Hansson, A., \& Lind, M. (2012). Obstacles for CCS deployment: an analysis of discrepancies of perceptions. Mitigation and Adaptation Strategies for Global Change, 17(6), 601-619. http://doi.org/ $10.1007 / \mathrm{s} 11027-011-9353-3$

Stirling, A. (2004). Opening up or closing down: analysis, participation and power in the social appraisal of technology. In M. Leach, I. Scoones, \& B. Wynne (Eds.), Science, Citizenship and Globalisation. London: Zed.

Swierstra, T., \& Te Molder, H. (2012). Risk and soft impacts. In S. Roeser, R. Hillerbrand, M. Peterson, \& P. Sandin (Eds.), Handbook of risk theory (pp. 1050-1066). Dordrecht: Springer.

ter Mors, E., Terwel, B., \& Daamen, D. (2012). The potential of host community compensation in facility siting. International Journal of Greenhouse Gas Control, (0).

Terwel, B., Daamen, D., \& ter Mors, E. (2013). Not in my Back Yard (NIMBY) Sentiments and the Structure of Initial Local Attitudes Toward $\mathrm{CO}_{2}$ Storage Plans. Energy Procedia, 37, 7462-7463. http://doi.org/ 10.1016/j.egypro.2013.06.689

Terwel, B., Harinck, F., Ellemers, N., \& Daamen, D. (2009). How organizational motives and communications affect public trust in organizations: The case of carbon dioxide capture and storage. Journal of Environmental Psychology, 29(2), 290-299.

Terwel, B., Harinck, F., Ellemers, N., Daamen, D., \& De Best-Waldhober, M. (2009). Trust as predictor of public acceptance of CCS. Energy Procedia, 1(1), 4613-4616.

Terwel, B., Koudenburg, F., \& ter Mors, E. (2014). Public Responses to Community Compensation: The Importance of Prior Consultations with Local Residents. Journal of Community \& Applied Social Psychology. http://doi.org/10.1002/casp.2186

Terwel, B., Ter Mors, E., \& Daamen, D. (2012). It's not only about safety: Beliefs and attitudes of 811 local residents regarding a CCS project in Barendrecht. International Journal of Greenhouse Gas Control, 9(0), 41-51.

Tickner, J. (1999). A map toward precautionary decision making. In C. Raffensperger \& J. Tickner (Eds.), Protecting public health and the environment: Implementing the precautionary principle (pp. 162-186). Washington: Island Press.

Turkenburg, W. (1992). $\mathrm{CO}_{2}$ removal; Some conclusions. Energy Conversion and Management, 33(5-8), 819-823.

Turkenburg, W. (2004). Energietransitie richting duurzaamheid: technologisch perspectief (Achtergrondstudie bij het advies “Energietransitie: klimaat voor nieuwe kansen”). Den Haag: VROM-raad, Algemene Energieraad \& Copernicus Instituut.

Unruh, G. (2000). Understanding carbon lock-in. Energy Policy, 28(12), 817-830.

Urry, J. (2003). Global complexity. London: Polity Press.

van Alphen, K. (2011). Accelerating the development and deployment of carbon capture and storage technologies - An innovation system perspective. University of Utrecht, Utrecht.

van Asselt, M., \& Renn, O. (2011). Risk governance. Journal of Risk Research, 14(4), 431-449.

van Asselt, M., \& Rotmans, J. (1996). Uncertainty in perspective. Global Environmental Change, 6(2), 121-157. 
van den Broek, M., Hoefnagels, R., Rubin, E., Turkenburg, W., \& Faaij, A. (2009). Effects of technological learning on future cost and performance of power plants with $\mathrm{CO}_{2}$ capture. Progress in Energy and Combustion Science, 35(6), 457-480. http://doi.org/10.1016/j.pecs.2009.05.002

Van der Sluijs, J., \& Turkenburg, W. (2006). Climate change and the precautionary principle. In E. Fisher, J. Jones, \& R. Von Schomberg (Eds.), Implementing the precautionary principle: Perspectives and prospects. Cheltenham: Edward Elgar Publishing.

Van der Sluijs, J., Van Est, R., \& Riphagen, M. (2010). Beyond consensus: reflections from a democratic perspective on the interaction between climate politics and science. Current Opinion in Environmental Sustainability, 2(5), 409-415.

van Eeten, M. (2010). De diva en het noodlot. Kan de kiezer worden behaagd met fatalisme? Magazine Nationale Veiligheid En Crisisbeheersing (Ministerie van Binnenlandse Zaken En Koninkrijksrelaties), 8(4), 12.

van Eeten, M., Noordegraaf-Eelens, L., Ferket, J., \& Februari, M. (2012). Waarom burgers risico's accepteren en waarom bestuurders dat niet zien. The Hague: Ministerie van Binnenlandse Zaken en Koninkrijksrelaties.

van Egmond, S., \& Hekkert, M. (2012). Argument map for carbon capture and storage. International Journal of Greenhouse Gas Control, 11, Supplement, S148-S159. http://doi.org/10.1016/j.ijggc.2012.08.010

Van Est, R., \& Verbong, G. (2007). Linkse keuzes voor de eeuw van de energie - Energie in de poldermix. Socialisme \& Democratie, 64(1), 43-50.

van Lente, H. (1993). Promising technology: The dynamics of expectations in technological developments. Enschede.

van Luijk, J. (2003). Feasibility of the Shell-NAM CO 2 reduction project by subsurface storage in a depleted gas field. NAM.

Vann, A., \& Parfomak, P. (2008). Regulation of carbon dioxide $\left(\mathrm{CO}_{2}\right)$ sequestration pipelines: Jurisdictional issues. Report prepared for Members and Committees of US Congress.

Verbong, G., van Selm, A., Knoppers, R., \& Raven, R. (2001). Een kwestie van lange adem: De geschiedenis van duurzame energie in Nederland. Boxtel: Aeneas.

Vergragt, P. (2009a). CCS in the Netherlands: Glass half empty of half full? In J. Meadowcroft \& O. Langhelle (Eds.), Caching the carbon: The politics and policy of carbon capture and storage (pp. 186-210). Cheltenham: Edward Elgar.

Vergragt, P. (2009b). CCS: The next technological lock-in? A case study from the Netherlands.

Vergragt, P., Markusson, N., \& Karlsson, H. (2011). Carbon capture and storage, bio-energy with carbon capture and storage, and the escape from the fossil-fuel lock-in. Global Environmental Change, 21(2), 282-292.

Vlek, C. (2004). Environmental versus individual risk taking: perception, decision, behaviour. In C. Spielberger (Ed.), Encyclopedia of Applied Psychology. San Diego: Academic Press.

Vogel, D. (1986). National styles of regulation: Environmental policy in Great Britain and the United States. Ithaca: Cornell University Press.

Vollenbroek, F. A. (2002). Sustainable development and the challenge of innovation. Journal of Cleaner Production, 10(3), 215-223. http://doi.org/10.1016/S0959-6526(01)00048-8

VROM-Raad. (2001). Waar een wil is, is een weg: Advies over het NMP4. Raad voor de volkshuisvesting, de ruimtelijke ordening en het milieubeheer.

Wade, S., \& Greenberg, S. (2011). Social Site Characterisation: From Concept to Application - A review of relevant social science literature and a toolkit for social site characterisation. Global CCS Institute.

Wiener, J. (2004). The regulation of technology, and the technology of regulation. Technology in Society, 26(2-3), 483-500.

Wiener, J., Rogers, M., Hammitt, J., \& Sand, P. (2011). The Reality of Precaution: Comparing Risk Regulation in the United States and Europe. London: Earthscan.

Wildenborg, T., Coussy, P., Doukelis, A., Ekström, C., Georgiou, G., Gkountanis, S.,... Simonsson, D. (2009). Scenario for large-scale implementation of CCS in Europe. Energy Procedia, 1(1), 4265-4272. 
Wilson, E., Friedmann, S., \& Pollak, M. (2007). Research for deployment: Incorporating risk, regulation, and liability for carbon capture and sequestration. Environmental Science \& Technology, 41(17), 5945-5952.

Wilson, E., Johnson, T., \& Keith, D. (2003). Regulating the Ultimate Sink: Managing the Risks of Geologic $\mathrm{CO}_{2}$ Storage. Environmental Science \& Technology, 37(16), 3476-3483.

Wilson, E., Stephens, J., Rai Peterson, T., \& Fischlein, M. (2009). Carbon capture and storage in context: The importance of state policy and discourse in deploying emerging energy technologies. Energy Procedia, 1(1), 4519-4526.

Wilson, E., Zhang, D., \& Zheng, L. (2011). The socio-political context for deploying carbon capture and storage in China and the U.S. Global Environmental Change, 21(2), 324-335.

Winner, L. (1993). Upon Opening the Black Box and Finding It Empty: Social Constructivism and the Philosophy of Technology. Science, Technology \& Human Values, 18(3), 362-378.

Witlox, H., Harper, M., \& Oke, A. (2009). Modelling of discharge and atmospheric dispersion for carbon dioxide releases. Journal of Loss Prevention in the Process Industries, 22, 795-802.

Wong-Parodi, G., Ray, I., \& Farrell, E. (2008). Environmental non-government organizations' perceptions of geologic sequestration. Environmental Research Letters, 3, 1-8.

WRR. (2009). Uncertain safety: Allocating responsibilities for safety. Scientific Council for Government Policy.

Wurzel, R., Zito, A., \& Jordan, A. (2013). Environmental Governance in Europe: A Comparative Analysis of the Use of New Environmental Policy Instruments. London: Edward Elgar Publishing. Retrieved from http://www.elgaronline.com/view/9781849804660.xml?rskey=M9gVZl\&result=17

Wyatt, S. (2008). Technological determinism is dead; Long live technological determinism. In E. J. Hackett, O. Amsterdamska, M. Lynch, \& J. Wajcman (Eds.), The handbook of science and technology studies (pp. 165180). London: MIT Press.

Wynne, B. (1987). Risk management and hazardous waste: Implementation and the dialectics of credibility. London: Springer Verlag.

Wynne, B. (2003). Seasick on the Third Wave? Subverting the Hegemony of Propositionalism: Response to Collins \& Evans (2002). Social Studies of Science, 33(3), 401-417.

Wynne, B. (2005). Risk as globalizing "democratic" discourse? Framing subjects and citizens. In M. Leach, I. Scoones, \& B. Wynne (Eds.), Science and Citizens: Globalization and the challenge of engagement (pp. 66-82). London: Zed Books.

Wynne, B. (2007). Public Participation in Science and Technology: Performing and Obscuring a PoliticalConceptual Category Mistake. East Asian Science, Technology and Society, 1(1), 99-110. http://doi.org/ 10.1215/s12280-007-9004-7

Young-Lorenz, J. D., \& Lumley, D. (2013). Portfolio Analysis of Carbon Sequestration Technologies and Barriers to Adoption: General Methodology and Application to Geological Storage. Energy Procedia, 37, 5063-5079. http://doi.org/10.1016/j.egypro.2013.06.420

Zeiss, R. (2004). Standardising materiality - Tracking co-constructed relationships between quality standards and materiality in the English water industry. PhD Thesis: University of York.

Zwartkruis, J. (2013). Framing in innovation: towards sustainable agro-food systems (PhD thesis). Utrecht: Utrecht University. 


\section{Nederlandse samenvatting}

Dit proefschrift onderzoekt de moeizame invoering van een omstreden klimaatstrategie: ondergrondse $\mathrm{CO}_{2}$ opslag (in het Engels: Carbon Capture and Storage ofwel CCS). CCS is een verzamelnaam voor de verschillende technieken die nodig zijn om $\mathrm{CO}_{2}$ van grote fossiele bronnen zoals kolencentrales, cementfabrieken of olieraffinaderijen af te vangen, te comprimeren, te transporteren en vervolgens op te slaan in aardlagen diep onder de grond. $\mathrm{Al}$ sinds de jaren '80 doet een internationale groep van geofysici, petrochemici, economen, beleidsmakers, regelgevers, juristen en milieu-deskundigen onderzoek naar CCS. De dominante argumentatielijn die deze groep bindt is de volgende: 'menselijk handelen leidt tot klimaatverandering en $\mathrm{CO}_{2}$ is het voornaamste broeikasgas; economische groei gaat gepaard met een toenemende consumptie van fossiele brandstoffen en daarmee met een stijging in $\mathrm{CO}_{2}$ emissies; het is sociaal, politiek en economisch gezien onwenselijk (en praktisch gezien onmogelijk) om het werelwijde gebruik van fossiele brandstoffen drastisch te verminderen; CCS is de enige manier om de $\mathrm{CO}_{2}$-emissies die horen bij het gebruik van fossiele bronnen drastisch te verminderen; daarom is grootschalige invoering van CCS noodzakelijk om klimaatverandering tegen te gaan'.

Vanuit bovenstaande argumentatielijn is veel geïnvesteerd in CCS onderzoek. Er is uitgebreid gekeken naar o.a. de veiligheid van $\mathrm{CO}_{2}$-opslag, naar de meest efficiënte manier van $\mathrm{CO}_{2}$-afvang en naar economische aspecten. Invloedrijke studies suggereren dat er geen technisch-wetenschappelijke obstakels zijn die grootschalige invoering van CCS in de weg staan. Inmiddels vormt $\mathrm{CO}_{2}$-opslag dan ook in vrijwel alle grote economieën een cruciaal onderdeel van het klimaatbeleid. En toch verloopt de invoering van CCS traag. Diverse demonstratieprojecten zijn afgeblazen, er is sprake van maatschappelijke weerstand en wereldwijd wordt veel minder $\mathrm{CO}_{2}$ opgeslagen dan verwacht. Dat is de centrale puzzel die dit proefschrift behandelt: gegeven dat de grootschalige invoering van CCS algemeen als een noodzakelijke, veilige en technisch haalbare klimaatstrategie wordt gezien, hoe is dan te begrijpen dat de invoering zo traag verloopt? 
Om tot een antwoord te komen hanteer ik een governance-perspectief: ik onderzoek hoe in verschillende contexten sturing wordt gegeven aan de invoering van CCS. Sturing vindt plaats op het niveau van beleid, besluitvorming en regelgeving. Het vraagt om een samenspel van partijen. Maar ook technisch-wetenschappelijke kennis speelt een belangrijke rol. CCS is voor velen namelijk een impopulaire maatregel. Daarom maken partijen gebruik van rapporten, berekeningen en studies om de invoering van CCS te legitimeren. Dergelijke kennis blijkt niet onomstreden, zoals ik in drie case-studies laat zien. Methodisch is ervoor gekozen om zogenaamde hard cases te selecteren: het zijn contexten waar claims over respectievelijk de noodzakelijkheid, veiligheid en technische haalbaarheid van CCS het meest overtuigend leken, maar waar de invoering van CCS toch moeizaam verliep. Per hoofdstuk wordt op een ander 'sturingselement' ingezoomd (beleid, besluitvorming en regelgeving). Dit onderscheid is artificieel; bij de invoering van CCS spelen alle elementen in samenhang een rol. Maar het onderscheid helpt om de centrale vraag te beantwoorden. Per hoofdstuk wordt namelijk een ander analytisch perspectief aangereikt om te begrijpen waarom de invoering van CCS zo moeizaam verloopt (imaginaries, frames/overflows en grenswerk). Hierbij maak ik gebruik van inzichten uit het veld van Science \& Technology Studies.

In hoofdstuk 2 laat ik zien hoe CCS een noodzakelijk onderdeel is geworden van het Nederlandse klimaat- en energiebeleid. Dit doe ik door het ontstaan van een specifieke 'socio-technische verbeelding' (imaginary) te traceren, volgens welke Nederland een internationaal knooppunt kan worden voor internationale stromen van energie, mensen, goederen en $\mathrm{CO}_{2}$. Op basis van de literatuur onderscheid ik verschillende kenmerken van een sociotechnische verbeelding: (i) zij geeft aan welke risico's en kansen te verwachten zijn wanneer een techniek te snel of juist te langzaam wordt ingevoerd en geeft zo een specifieke aanzet tot verandering, (ii) zij wordt gekenmerkt door bepaalde manieren (kennispraktijken) om de energietoekomst te exploreren en te onderzoeken welke collectieve toekomst realistisch is, (iii) zij suggereert wie verantwoordelijk is voor het realiseren van de beoogde nationale toekomst en (iv) zij omvat de middelen, instrumenten en spelregels die partijen moeten volgen om deze toekomst te realiseren. Een socio-technische verbeelding is dus meer dan een beleidsagenda of een particuliere toekomstvisie. Het verwijst naar het cultureel ingebedde reservoir van normen, vertogen en praktijken van waaruit specifieke beleidsdoelen, toekomstvisies en technologieprojecten ontstaan. De nationale verbeelding van Nederland als internationale energiehub speelt dan ook een belangrijke rol bij de invoering van CCS.

Vanaf de jaren '80 bieden twee afzonderlijke risico's aanzet tot verandering van de $\mathrm{Ne}$ derlandse energievoorziening. Enerzijds is het risico van klimaatverandering steeds prominenter op de agenda gekomen. Dit globale, ambigue risico wordt vertaald in concrete en ambitieuze doelen voor $\mathrm{CO}_{2}$-emissiereducties. Anderzijds is men zich bewust van de kwets- 
baarheid van de 'open' Nederlandse economie. Vooral na de liberalisering en harmonisering van de Europese energiemarkt is er de vrees dat een stringent nationaal klimaatbeleid schadelijk is voor de concurrentiepositie van de eigen economie. Nederland heeft zich sterk gemaakt voor een flexibele en internationale aanpak van het klimaatprobleem en was groot voorstander van het EU emissiehandelssysteem (EU-ETS) dat in 2005 werd ingevoerd. Dit cap-and-trade systeem stelt een plafond aan de totale $\mathrm{CO}_{2}$-uitstoot van een industriële sector. Individuele bedrijven (b.v. electriciteitscentrales) hebben het recht om een bepaalde hoeveelheid $\mathrm{CO}_{2}$ uit te stoten. Wanneer men emissie-ruimte overhoudt, kan men een deel van de $\mathrm{CO}_{2}$-rechten verkopen. En om meer $\mathrm{CO}_{2}$ uit te stoten, moet men extra rechten kopen. Met de invoering van het EU-ETS is $\mathrm{CO}_{2}$ dus een handelsstroom geworden. Daar komt bij dat de opvattingen over een ander risico (de verwachtte schaarste van fossiele bronnen) sinds de jaren '90 sterk zijn veranderd. Er heeft daarbij een herformulering van het klimaatprobleem plaats gevonden. Aanvankelijk was het beleid gericht op het verminderen van fossiele energiestromen in Nederland. Voortaan is het doel om de energievoorziening zo 'schoon' mogelijk te maken. Stromen van fossiele energiedragers kunnen daarin nog steeds een plaats hebben, aangezien de verwachting is dat Nederland ook de bijbehorende $\mathrm{CO}_{2}$-stromen zal kunnen accomoderen.

Deze verwachting is gebaseerd op twee belangrijke kennispraktijken: scenario-studies en de participatieve 'back-casting' methodiek. Deze methoden hebben gemeen dat ze niet alleen naar technisch-economische eigenschappen kijken om in te schatten hoeveel $\mathrm{CO}_{2}$ reductie een bepaalde klimaatstrategie in de toekomst kan opleveren. Ook een inschatting van het toekomstige maatschappelijk draagvlak voor deze klimaatstrategie is belangrijker. Dit past binnen de verschuiving van verantwoordelijkheden die aan het begin van de $21^{\text {ste }}$ eeuw optrad in Nederland. De keuze voor een specifieke klimaatoptie wordt niet langer van bovenaf opgelegd, maar wordt aan de markt overgelaten. De overheid is zich steeds meer op gaan stellen als facilitator van verandering. Lange-termijn verandering moeten worden gerealiseerd door een netwerk van partijen. Het exploreren van 'de' gezamelijke energietoekomst is daarmee een participatieve praktijk, waarbij vertegenwoordigers van de industrie, de milieubeweging en maatschappelijke partijen samen een balans trachten te vinden tussen wensdenken en realisme.

Het is verder kenmerkend dat overheidssteun voor een specifieke klimaatstrategie in Nederland slechts gelegitimeerd wordt door duidelijk te maken dat 'de natie als geheel' hier baat bij zal hebben (in plaats van één specifieke bedrijfstak). Het EU-ETS maakt dit mogelijk in geval van CCS. $\mathrm{CO}_{2}$ uitstoot is een productstroom geworden. Zo zou ook het aanleggen van een gedeelde $\mathrm{CO}_{2}$-infrastructuur in het voordeel zijn van de gehele 'BV Nederland'. Nederland zou een aantrekkelijke vestigingsplaats kunnen blijven voor energieintensieve bedrijven én zou een internationale koploper op het gebied van $\mathrm{CO}_{2}$-reducties 
kunnen worden. CCS projecten gaan dan ook vaak gepaard met beelden van $\mathrm{CO}_{2}$-hubs en $\mathrm{CO}_{2}$-rotondes. Dergelijke beelden referen effectief aan de eerdere collectieve ervaring met het aanleggen van een landelijke gasinfrastructuur welke Nederland in het verleden ook veel welvaart heeft gebracht. Beelden van $\mathrm{CO}_{2}$-hubs, hoe rudimentair ook, helpen zo om het algemeen belang van CCS te onderstrepen.

In Nederland ontstaan CCS projecten dus tegen de achtergrond van een bepaalde sociotechnische verbeelding, volgens welke het land als geheel beter af is wanneer zij een knooppunt vormt voor internationale stromen van goederen, energie en $\mathrm{CO}_{2}$. Ik laat vervolgens zien dat deze toekomstverbeelding sterk performatief is. Het maakt het mogelijk om enerzijds strenge $\mathrm{CO}_{2}$-reductiedoelen te formuleren en anderzijds de bouw van nieuwe kolencentrales te legitimeren. Het is deze combinatie die de invoering van CCS in Nederland verder 'noodzakelijk' heeft gemaakt en overheidssteun voor CCS demonstratieprojecten legitimeerde. Tegelijk brengt de socio-technische verbeelding ook een sturingsprobleem met zich mee: de fossiele industrie heeft zich weliswaar vrijwillig achter de visie van een collectieve $\mathrm{CO}_{2}$-hub geschaard, maar individuale partijen kunnen niet gedwongen worden om daadwerkelijk in CCS te investeren als zij daar zelf niet de economische noodzaak toe zien. Een dergelijke verplichting zou immers de nationale concurrentiepositie binnen de Europese markt kunnen schaden. Zo valt te begrijpen dat vroegtijdige implementatie van CCS in Nederland als noodzakelijk geldt en in het algemeen belang, maar dat de daadwerkelijke invoering ten tijde van een lage $\mathrm{CO}_{2}$ prijs toch niet wordt afgedwongen.

In hoofdstuk 3 verleg ik de focus naar de besluitvorming rond een concreet CCS project. Als casus is gekozen voor een demonstratieproject dat volgens de initiatiefnemers 'veilig' was, maar waarbij het toch moeilijk bleek om tot een gezaghebbend besluit te komen. Om inzicht te geven in de dynamiek van het besluitvormingsproces wijs ik op de rol van frames en overflows. Een frame is een culturele ruimte waarbinnen sociale interacties plaatsvinden en betekenis krijgen. Frames geven een zekere voorspelbaarheid aan onze interacties, doordat zij ongeschreven regels bevatten en een bepaalde rolverdeling impliceren. Denk bijvoorbeeld aan een hoorcollege: binnen dit frame geldt een onderscheid tussen spreker en toehoorders, de spreker staat er niet als privé-persoon maar als vertegenwoordiger van een bepaald kennisdomein, toehoorders weten doorgaans wanneer een interruptie geaccepteerd is en wanneer niet, et cetera. Ook in besluitvormingsprocessen spelen frames een belangrijke rol, omdat zij de complexiteit van de buitenwereld tijdelijk verkleinen. Zij suggereren welke kennis relevant is en welke niet, welke onderwerpen aan de orde moeten komen en welke niet, wie als expert geldt en wie als leek. Maar een frame kan ook onder druk komen te staan. Er is dan sprake van zogenaamde 'overflows'. Dit zijn situaties waarbij actoren zich niet schikken in hun toebedeelde rol, waarbij andere onderwerpen plotseling ook relevant blijken en nieuwe vragen of onzekerheden zich aandienen. 
Vanuit het perspectief op frames en overflows reconstrueer ik het besluitvormingproces rond het CCS project in Barendrecht. De Milieu Effect Rapportage (MER) was de geïnstitutionaliseerde weg om input te geven aan politieke besluitvorming over dit project. In het frame van de MER-procedure beperkten interacties zich tot het thema 'veiligheid': de centrale vraag was namelijk of de risico's van NAM/Shell's project binnen de gestelde wettelijke normen vielen. Maar volgens lokale politici was dit kader te beperkt. Zij vonden dat andersoortige effecten van ondergrondse $\mathrm{CO}_{2}$-opslag (bijvoorbeeld m.b.t. lokale huizenprijzen of veiligheidsgevoelens) ook meegenomen moesten worden in de besluitvorming. Daarnaast vonden zij dat ook de veiligheidsstudies zelf anders geframed moesten worden (door bijvoorbeeld ook het risico op niet-dodelijke incidenten mee te nemen).

Lokale politici stelden daarom een eigen toetskader op. Om vanuit dit bredere frame de besluitvorming te informeren werd een zogenaamde Kennistafel georganiseerd. Dit is op te vatten als een bijzonder soort participatief experiment, ofwel een 'hybride forum'. De hybriditeit zit erin dat de Kennistafel Sessies een subtiele verschuiving van relevante invalshoeken, van representativiteit en van relevante expertise toelieten ten opzichte van het MER frame. Dit is duidelijk wanneer we kijken naar de rol van verschillende deelnemers. Lokale politici hadden, na het opstellen van hun eigen toetskader, 'kritische deskundigen' in de arm genomen. Ik laat zien dat deze deskundigen een hybride rol speelden in de Kennistafel Sessies: enerzijds wisten zij genoeg van een bepaald onderwerp om de claims van gecertificeerde deskundigen kritisch te bevragen, anderzijds probeerden zij om de zorgen van bewoners te vertegenwoordigen tijdens het expert-debat dat achter gesloten deuren plaatsvond. Als hybride forum leverde de Kennistafel nieuwe kennis op. Ook functioneerde zij als kwaliteitscheck van al gedane studies. Maar volledige zekerheid gaf zij niet, al was het maar omdat veiligheidsstudies rond CCS op modellen waren gebaseerd en er volgens critici nog te weinig praktijkervaring was om deze modellen te ijken. Onzekerheid vormde zo een hardnekkige overflow. In 2009 stemden lokale partijen dan ook unaniem tegen NAM/Shell's project, omdat de veiligheid niet gegarandeerd kon worden en er onder bewoners grote bezorgdheid leefde over de veiligheid.

Dit was allerminst het einde van de risico-controverse. Medio 2009 werd de beslisbevoegdheid naar het nationale niveau geschoven. De verantwoordelijke ministers lieten wederom extra onderzoeken uitvoeren naar verschillende overflows (bijvoorbeeld naar de psychosomatische gevolgen van $\mathrm{CO}_{2}$-opslag). Ook het nationale CCS onderzoeksnetwerk CATO speelde een belangrijke rol bij het beteugelen van de overflows die een gezaghebbend besluit in de weg stonden. Ik onderscheid een vijftal relevante activiteiten. CATOleden voerden (i) wetenschappelijk onderzoek uit naar de risico's van CCS en (ii) naar risico-percepties. De opgedane inzichten werden vertaald in (iii) risico-communicatie, bedoeld om het publieke debat over de veiligheid van CCS te informeren. Er werd bijvoor- 
beeld geprobeerd om een onderscheid te maken tussen feiten en meningen. Daarnaast werd (iv) wetenschappelijk onderzoek gedaan naar de resterende onzekerheden en kennislacunes m.b.t. de veiligheid van $\mathrm{CO}_{2}$-transport en ondergrondse opslag. Sommigen, waaronder leden van de internationale CCS gemeenschap zelf, twijfelden echter aan de onafhankelijkheid en het zelfkritische vermogen van gecertificeerde CCS deskundigen. Daarom zochten CATO-leden naar manieren om (v) de culturele ruimte voor expert-debat te verbreden, zodat ook kritische geluiden en minderheids-standpunten zouden worden gehoord.

Critici van het Barendrecht project werden bijvoorbeeld uitgenodigd om deel te nemen aan een zogenaamde 'Fact Finding Workshop'. Ook dit hybride forum resulteerde in nieuwe veiligheidskennis, maar leidde niet tot consensus. Gecertificeerde deskundigen lichtten toe hoe zij de wettelijk voorgeschreven risicobenadering hadden gehanteerd. Maar critici trokken de waarde van deze benadering in twijfel: zij wezen op resterende onzekerheden en op een potentiële mismatch tussen model-berekeningen en lokale omstandigheden. En zo sudderde de risico-discussie voort. In 2010 besloot de nieuw-gekozen Minister van Economische Zaken tenslotte om het project te stoppen, vanwege de opgelopen vertraging en het gebrek aan lokaal draagvlak.

Het perspectief op frames en overflows maakt duidelijk dat de besluitvorming rond het Barendrecht project niet puur technocratisch verliep. Mijn analyse laat de subtiele, reflexieve manieren zien waarop partijen hebben geprobeerd om het nauwe frame van de MER te verbreden en de overflows te beperken. Er werd niet alleen méér veiligheidsonderzoek gedaan, maar ook anderssoortig veiligheidsonderzoek. Toch bleek het moeilijk om tot een afwegingskader te komen dat de goedkeuring had van alle betrokken partijen. Waarom was het zo moeilijk om de veiligheidsdiscussie te beslechten? Veel critici twijfelden aan het nut van NAM/Shell's project of noodzaak van CCS in het algemeen. Maar het was lastig om deze overflow in het besliskader van dit concrete project te betrekken. Binnen de Nederlandse socio-technische verbeelding was de 'noodzakelijkheid' van CCS immers een thema dat op nationaal niveau besproken dient te worden door vertegenwoordigers van de industrie, milieubeweging en kennisinstellingen (zie hoofdstuk 2). Dit maakte dat de discussie rond het Barendrecht project zich tot een veiligheids-discussie vernauwde én dat het moeilijk was om tot en gezaghebbend oordeel over veiligheid te komen. Critici wezen effectief op onzekerheden in de risico-berekeningen om overflows rond het geïnstitutionaliseerde veiligheids-frame te creëeren en zo de besluitvorming te vertragen.

Naast effectief klimaatbeleid en doortastende besluitvorming rond concrete projecten vraagt de invoering van CCS ook om passende regelgeving. In hoofdstuk 4 hanteer ik een perspectief op grenswerk om de dynamiek van het regulatieve proces te duiden. Bij het legitimeren van nieuwe regelgeving spelen technisch-wetenschappelijke argumenten doorgaans een belangrijke rol. Denk bijvoorbeeld aan strengere milieu-eisen voor de uitstoot van 
een bepaalde vervuilende stof: deze kunnen gelegitimeerd worden door te wijzen op nieuwe wetenschappelijke inzichten over de schadelijke gevolgen van de stof of door te wijzen op de beschikbaarheid van een nieuwe emissie-reductietechniek. Als deze techniek voldoende doorontwikkeld is en behoort tot de 'stand der techniek', is het legitiem om van commerciele partijen te eisen dat zij deze standaard toepassen in hun producten. Echter, in de regulatieve praktijk is het onderscheid tussen wetenschappelijke en politieke overwegingen vaak omstreden. Daarom beschouwt de academische literatuur rond grenswerk dit onderscheid als sociaal geconstrueerd. Anders gezegd: er zijn geen absolute, vaststaande criteria om te bepalen of een argument wetenschappelijk of politiek van aard is. Men kan 'wetenschap' beter begrijpen als een cultureel gebied op een metaforische kaart. Grenswerk verwijst dan naar de verschillende manieren waarop partijen een onderscheid weten aan te brengen tussen het technisch-wetenschappelijke domein en andere culturele domeinen (zoals 'pseudo-wetenschap' of 'politiek'). Het perspectief op grenswerk levert zo een belangrijk inzicht op: het invoeren van gezaghebbende CCS regelgeving vraagt om het balanceren tussen technisch-wetenschappelijke en sociaal-politieke overwegingen, en tegelijk om het construeren van een metaforische grens tussen beide domeinen.

In hoofdstuk 4 onderzoek ik de invoering van een belangrijke regulatieve standaard; deze standaard moet garanderen dat de $\mathrm{CO}_{2}$-uitstoot van nieuwe kolencentrales significant lager zal zijn dan die van bestaande kolencentrales (namelijk doordat CCS wordt toegepast). Ik richt mij hierbij op de Amerikaanse context. De Verenigde Staten, en specifiek de staat Illinois, wil al jaren een koploper zijn op het gebied van 'clean coal technologies'. Er is veel onderzoek gedaan naar CCS. Er zijn verschillende demonstratieprojecten uitgevoerd. Illinois was de eerste Amerikaanse staat die wettelijk vastlegde dat een deel van haar stroom afkomstig moet zijn van 'schone' kolencentrales. Het lijkt in deze context dus evident dat het technisch haalbaar is om $\mathrm{CO}_{2}$ van een werkende kolencentrale af te vangen en op te slaan. En toch werd de technische haalbaarheid van CCS een groot discussiepunt. In dit hoofdstuk laat ik zien hoe de Amerikaanse milieudienst EPA middels grenswerk op verschillende niveaus (federaal en statelijk) trachtte om een strenge $\mathrm{CO}_{2}$-standaard voor nieuwe kolencentrales in te voeren. Ik interpreteer grenswerk daarbij als een discursieve en organisatorische praktijk, waarbij EPA een technisch-wetenschappelijke legitimatie voor haar regelgeving trachtte af te bakenen.

EPA is pas sinds 2009 gemachtigd om de Amerikaanse $\mathrm{CO}_{2}$-uitstoot te beperken. Een eerste stap daarbij is het invoeren van een zogenaamde 'performance standard' voor nieuwe kolencentrales (in $\mathrm{CO}_{2} / \mathrm{MWh}$ ). De Clean Air Act stelt dat deze standaard gebaseerd moet zijn op emissie-reductietechnieken die 'voldoende bewezen' zijn. Is CCS voldoende bewezen? En wat betekent het eigenlijk om de werking en haalbaarheid van CCS te bewijzen? Deze vragen lopen als een rode draad door het regulatieve debat. En het debat liep hoog op. 
EPA ontving letterlijk miljoenen reacties op haar voorstellen. Critici verweten de milieudienst dat zij onder de Obama-regering een oorlog voerde tegen de Amerikaanse kolenindustrie en bewust onhaalbare milieu-eisen stelde. In deze adversieve politieke cultuur moest EPA laten zien dat haar $\mathrm{CO}_{2}$-standaard op zuiver technisch-wetenschappelijke gronden was gebaseerd en niet op een politieke agenda.

EPA opereerde autocratisch noch technocratisch. De milieudienst betrok vertegenwoordigers van de kolenindustrie, de milieubeweging en het Amerikaanse publiek actief in het regulatieve proces. Partijen bleken sterk van mening te verschillen over de status en resterende onzekerheden van full-scale CCS. Om dit verschil van inzicht te nivelleren (en de onzekerheden te 'normaliseren') gebruikte EPA verschillende rhetorische middelen. De milieudienst verwees bijvoorbeeld naar het emissieprofiel van gasgestookte elektriciteitscentrales als een 'golden standard'. Om deze standaard te halen hoefden nieuwe kolencentrales slechts een gedeelte van hun $\mathrm{CO}_{2}$ af te vangen en op te slaan. Hiermee suggereerde EPA ook dat CCS slechts gedeeltelijk bewezen hoefde te zijn. Verder verwees de milieudienst naar economische studies als bewijs dat (a) de resterende onzekerheden in de toekomst weggenomen zouden worden door nieuwe demonstratieprojecten en dat (b) marktschommelingen in de energiesector een grotere onzekerheid met zich meebrachten voor de bouw van nieuwe kolencentrales dan de gevraagde toepassing van CCS. Desondanks kreeg de voorgestelde standaard veel kritiek. EPA paste hierop zowel de standaard als de onderbouwing aan. De nieuw voorgestelde standaard vroeg bijvoorbeeld alleen om $\mathrm{CO}_{2}$-afvang: dit suggereerde dat ook alleen $\mathrm{CO}_{2}$-afvang technieken bewezen hoefden te zijn en plaatste onzekerheden rond $\mathrm{CO}_{2}$-opslag buiten de discussie. Om een gezaghebbende $\mathrm{CO}_{2}$ standaard in te voeren liet EPA dus zien dat CCS voldeed aan het criterium van 'voldoende bewezen' en gaf zij tegelijk rhetorisch vorm aan dit criterium in het regulatieve proces.

Het grenswerk van EPA kende ook een organisatorische dimensie, zoals mijn analyse van de vergunningsverlening rond een nieuwe elektriciteitscentrale in Illinois duidelijk maakt (2009-2015). De initiatiefnemers van deze 'schone' kolencentrale ontvingen aanzienlijke financiële steun om CCS op commerciële schaal te demonsteren. Om deze staatssteun te verkrijgen verwezen zij naar geologische rapporten en naar bestaande demonstratieprojecten elders in Illinois. Dit gold als bewijs dat CCS ook voor de nieuwe kolencentrale zeer kansrijk en beloftevol was. Maar ironisch genoeg wezen de initiatiefnemers tijdens de vergunningsverlening juist op de onzekerheden van CCS. Demonstratieprojecten elders in Illinois waren weliswaar succesvol, maar vormden onvoldoende bewijs dat $\mathrm{CO}_{2}$-opslag ook voor deze centrale haalbaar was. En men kon alleen theoretische rapporten gebruiken om de haalbaarheid van $\mathrm{CO}_{2}$-opslag te bewijzen, terwijl er volgens de initiatiefnemers 'praktisch bewijs' nodig was. Vergunningverlener Illinois-EPA ging mee in deze redenatie. Zij 
kwalificeerde $\mathrm{CO}_{2}$-opslag als 'niet technisch haalbaar' en stelde geen CCS-verplichting in, tot woede van de milieubeweging in Illinois.

Ik betoog dat hier sprake is van demonstrator's regress. Dit is de circulariteit die optreedt wanneer er nog geen sociaal geaccepteerd criterium is om te bepalen wanneer een technologie voldoende bewezen is: men kan dan altijd de representativiteit van gedane demonstratieprojecten in twijfel trekken en vragen om nieuwe demonstraties, uitgevoerd onder net andere omstandigheden. Om deze circulariteit te doorbreken is sociale interventie nodig. Dat is precies wat EPA deed. Het zette Illinois-EPA onder druk om haar vergunning te herzien. EPA leverde daarbij geen nieuwe bewijzen voor de haalbaarheid van CCS, maar spoorde Illinois-EPA aan om het beschikbare bewijs anders te interpreteren en de resterende onzekerheden rond $\mathrm{CO}_{2}$-opslag als normaal te beoordelen. De vergunning werd hierop ingetrokken en het demonstratieproject afgeblazen.

Mijn analyse toont zo het discursieve en organisatorische grenswerk waarmee EPA een technisch-wetenschappelijke basis voor haar $\mathrm{CO}_{2}$-standaard trachtte te geven. Maar de milieudienst opereerde allerminst in een vacuum. Haar bewegingsruimte werd sterk beïnvloed door politieke en juridische ontwikkelingen. Critici probeerden bijvoorbeeld de rol van industrie-experts in EPA's interne kwaliteitsprocedures te vergroten: deze zouden de technisch-wetenschappelijke kennis rond CCS anders beoordelen dan de geraadpleegde universiteitsdeskundigen hadden gedaan. Ook wezen critici op bestaande, maar vergeten wetgeving uit het George W. Bush tijdperk: die stelde dat gesubsidieerde demonstratieprojecten niet als bewijs mochten dienen voor de haalbaarheid van CCS en dus niet gebruikt konden worden om een strenge $\mathrm{CO}_{2}$-standaard te legitimeren. Tot slot interpreteerden critici het afblazen van grootschalige demonstratieprojecten, zoals die in Illinois, als bewijs dat CCS nog niet voldoende bewezen kón zijn. Zo werd het steeds lastiger voor EPA om vol te houden dat haar regelgeving op onomstreden technisch-wetenschappelijke grond was gebaseerd. Uiteindelijk koos de milieudienst dan ook voor een minder strenge standaard. Het is nog onduidelijk of deze stand zal houden na juridische oppositie en welk effect zij zal hebben op de invoering van CCS in de Verenigde Staten.

In hoofdstuk 5 kom ik tenslotte terug op de hoofdvraag. Mijn centrale claim is dat de drie perspectieven (imaginaries, frames/overflows en grenswerk) samen begrijpelijk maken hoe sturing wordt gegeven aan de invoering van CCS en waarom dit zo moeizaam verloopt, zelfs in contexten waar het evident leek dat ondergrondse $\mathrm{CO}_{2}$-opslag noodzakelijk, veilig en technisch haalbaar is. In samenhang bezien bieden de drie perspectieven het meeste inzicht. CCS projecten ontstaan tegen de achtergrond van een specifieke socio-technische verbeelding. Deze verbeelding heeft invloed op de framing van het besluitvormingsproces. Zo komen Amerikaanse demonstratieprojecten, anders dan in Nederland, bijvoorbeeld voort uit de nationale verbeelding van 'energie-onafhankelijkheid'. In deze verbeelding zijn 
individuele partijen (Amerikaanse bedrijven of consumenten) de legitieme begunstigden van technologische ontwikkeling. In deze context vindt besluitvorming rond individuele CCS projecten typisch plaats vanuit een economisch frame, waarbinnen voorspellingen over de effecten op de lokale werkgelegenheid en de energieprijzen belangrijk zijn om CCS projecten te legitimeren. Naast de nationale energieverbeelding en een frame voor besluitvorming speelt ook grenswerk een belangrijke rol bij de invoering van CCS: de risicobenadering die experts toepasten tijdens het Barendrecht-project was bijvoorbeeld het resultaat van eerder grenswerk door CCS deskundigen, bedoeld om politieke besluitvorming onder condities van wetenschappelijke onzekerheid te faciliteren.

Dit proefschrift resulteert in een conceptueel kader om te begrijpen hoe sturing wordt gegeven aan de invoering van CCS en waarom dit zo moeizaam verloopt. In democratische culturen speelt technisch-wetenschappelijke kennis een belangrijke rol bij het legitimeren van CCS. Maar deze kennis blijkt soms omstreden of machteloos tegenover de dominante marktlogica. Verschillende respondenten in mijn onderzoek suggereerden dan ook dat het mogelijk zou moeten zijn om de argumenten van klimaatsceptici, gefragmenteerde publieken of de gevestigde fossiele energiesector simpelweg terzijde te schuiven, zodat kosteneffectieve maar impopulaire klimaatmaatregelen zoals CCS kunnen worden geïmplementeerd. Dit lijkt mij een haalbare noch aantrekkelijke optie. Wel laat mijn proefschrift zien dat verdere reflectie op, en experimenteren met, alternatieve manieren om verandering van de fossiele energiesector te bewerkstelligen nodig is, gegeven de urgentie van het klimaatprobleem. 


\section{Valorisation addendum}

\section{Societal relevance}

Mitigating climate change is a major societal challenge. It is considered crucial to switch to a sustainable, low-carbon energy system. Many options are being pursued, like building wind mills, installing solar panels, developing smart grids for decentralized electricity production, increasing the use of alternative energy sources like biogas, shale gas or tidal waves, increasing energy efficiency in the build environment, reducing the carbon footprint of individual consumers, or developing an alternative infrastructure in which hydrogen is the primary energy carrier. However laudable such efforts are, it is also expected that fossil fuels will continue to be the primary energy source for decades to come. Capturing and sequestering the $\mathrm{CO}_{2}$ emissions from fossil-based power plants or heavy industry therefore plays an important role in the climate strategy of almost all developed economies.

This dissertation is of societal relevance, because it helps to understand some of the tensions, challenges and ironies involved in implementing CCS. This understanding is gained by not choosing sides. I do not answer the question whether CCS is necessary or not, whether CCS is safe or not, or whether the technologies involved are adequately demonstrated so that new coal plants can be forced to implement CCS. Instead, I show that parties differ in their understanding of the risks, benefits and uncertainties involved in CCS and trace how such differences are dealt with in specific contexts.

My research zooms in on the (contested) role of knowledge in the implementation of CCS. I emphasize that the necessity, safety and feasibility of CCS is constructed and not unambiguously given. There are two reasons for this emphasis. First, I seek acknowledgment that parties can rationally disagree about CCS without one being necessarily more rational or better informed than the other because I am convinced that this helps to increase mutual understanding between parties. This does not imply that all viewpoints are equal or that 'anything goes' in the governance of CCS. Debates on CCS are structured by existing rules 
and regulations. In turn, particular interpretations of the risks and benefits of CCS tend to be more salient than others, depending on the context. So, second, I insist that the relevance of knowledge is context-dependent, because this allows for reflexive learning amongst those involved in the governance of CCS. It is often suggested that parties should generate more knowledge about CCS and that the dissemination of such knowledge should be improved to prevent deadlock on CCS. I argue that one should simultaneously try to facilitate an inclusive, reflexive and situated debate on the conditions under which such knowledge may legitimize collective action on CCS.

\section{Stakeholders}

This dissertation is of relevance to various audiences. Below, I will sketch some relevant insights for specific stakeholder groups.

\section{Relevant insights for policy-makers and regulators}

(a) To reach a socially robust decision on CCS projects, affected parties will have to agree on the framing of the decision-making process.

What consequences of a CCS project have to be taken into account? In how far should broader issues be considered? What knowledge is needed for decision-making? And what to do if this knowledge is incomplete? To answer such questions in a socially robust manner, it is advisable to develop the decision-making frame in a reflexive and inclusive manner.

This is not easy, as decision-making frames are structured by existing rules and by broader political developments. In the Dutch context I observed for example the following challenge. Policy-makers treated the necessity of CCS as an ambiguous issue (calling for a broad public debate at the national level) and treated the safety of CCS as a complex issue (calling for focused inquiry at the local level). Such problem-structuration made sense from a policy perspective, but it turned out to be counter-productive. First, those confronted with a CCS project could only question the safety of this project, even though they wanted to discuss broader issues instead. Second, the local framing of safety was overruled when the responsible Ministers decided to shift the decision-making power to the national level and decided to follow the institutionalized safety frame instead. This resulted in an intractable risk controversy. 
(b) Be aware that projections of the future role of CCS are not neutral and that there is a governance tension in Dutch energy policies.

In the Netherlands, environmental and industrial parties have voluntarily subscribed to stringent $\mathrm{CO}_{2}$-emission reduction targets. This agreement is made possible by projections of the future role of CCS in the Netherlands and by visions of regional ' $\mathrm{CO}_{2}$ hubs'. It is suggested that the nation as a whole will benefit from installing such a shared $\mathrm{CO}_{2}$ infrastructure. Importantly, the promise of CCS also helped to legitimize the construction of new coal-fired power plants. This made CCS an even more important part of Dutch energy policies. But to actually implement CCS, energy companies are guided by the price of $\mathrm{CO}_{2}$ (which is set at the supranational level) and not by their voluntary commitment to national or regional climate objectives.

(c) Conducting demonstration projects will not automatically move CCS through the remaining stages of 'technology readiness', because the meaning of such projects is up for debate.

Policy papers often suggest that CCS has to move through different stages: pilot phase $\rightarrow$ small-scale demos $\rightarrow$ large-scale demos $\rightarrow$ commercial readiness.

Most policy-makers and regulators will know that this is a simplification. Innovation scholars have convincingly shown that technology development is rarely a linear process. Still, there is a dominant expectation in policy papers that demonstration projects will act as 'stepping stones' towards large-scale implementation of CCS.

My research indicates that this is not automatically the case. Even when CCS demonstration projects are conducted (and are not cancelled or delayed, like many have in recent years), parties may disagree about (i) the lessons learned and (ii) about the representativeness of such projects for other situations.

I cannot prescribe a recipe on how to deal with such disagreement. I do want to stress that demonstrating the working of CCS is not a purely technical or scientific act, but a political one too. In turn, democratic processes are needed to answer the question whether CCS technologies are 'adequately demonstrated' so that parties (be it industrial groups or local publics) can be forced to accept their implementation. 
Relevant insights for the general public or those confronted by CCS projects

(d) Techno-scientific knowledge on CCS is constructed. However, this does not mean that it is useless or necessarily flawed.

Claims about the necessity, safety and feasibility of CCS play an important role in the implementation of CCS. Throughout this dissertation, I have shown how the meaning and relevance of such claims became contested in various contexts. In doing so, I do not mean to suggest that the case for CCS is flawed.

By showing the complexities involved in the governance of CCS, I hope to counter cynicism and to provide further nuance to cultural stereotypes. Those working on CCS are not necessarily pro-industry or pro-coal, just like those critical of CCS are not necessarily uninformed or climate-deniers. I also hope that my research can contribute to a more 'realistic' understanding of the role of science and technology in our modern culture. Insisting that knowledge is constructed is not a plea for fact-free politics. It is an invitation for continued discussion on how knowledge on climate change and the deep underground can be used to shape our collective energy future, given that such knowledge is unavoidably limited.

\section{Activities}

To disseminate my research findings, I have undertaken (and plan to undertake) several activities. A first step has been to conduct interviews and to share my initial analysis with quoted respondents. Their feedback helped to improve my analysis of the selected cases, but it also helped to create awareness about my research. A second activity has been to present my findings on several conferences, including a colloquium on Responsible Innovation at Maastricht University and the annual conference of the European Society for Risk Analysis, which brought together policy-makers, regulators, social scientists and other professionals working on risk-related issues. Such multi-disciplinary meetings provided usual feedback on my analytical perspective and allowed me to share my findings.

As a third step, I will meet with a representative of the Dutch Ministry of Economic Affairs to share my findings and discuss the policy implications sketched above. After the public defense of my PhD thesis, I also plan to submit an article to the Dutch journal Nationale Veiligheid en Crisisbeheersing. This magazine is widely read by civil servants and professionals working in the field of national safety, risk governance and crisis control. 
Finally, I have disseminated my research through educational activities. I for example gave a guest-lecture on Engineering \& Social Responsibility to students of the University of Hasselt (Belgium) and gave several lectures for the Bachelor of Arts and Culture, the research Master on European Studies and the Master in Public Policy and Human Development at Maastricht University. 



\section{Curriculum Vitae}

Bart van Oost (1983, Groningen) started his academic studies at the Technical University of Eindhoven. He finished the BSc programme in Technology \& Society in 2006 with a specialization in sustainable energy. In the same year, he finished the BA programme in Philosophy at Tilburg University. In 2007, Bart earned a MA degree (cum laude) in European Studies of Society, Science \& Technology at Maastricht University. He spent several months at Université Louis Pasteur in Strasbourg for the specialization on risk governance. In 2009, Bart completed the MA programme in Social \& Political Philosophy at Nijmegen University, supported by a scholarship of the Radboud Foundation. His thesis focused on the knowledge/power nexus in the work of Michel Foucault.

After his studies, Bart worked freelance for the Rathenau Institute (department Technology Assessment). In 2009, he joined the Faculty of Arts \& Social Sciences at Maastricht University as a junior lecturer, where he was involved in BA and MA courses on e.g. politics of knowledge, discourse analysis and environmental policy-making. In September 2010, Bart started as a PhD researcher at the Department of Technology \& Society Studies. In 2013, he completed the graduate training program of the Netherlands Graduate Research School of Science, Technology and Modern Culture (WTMC). 